\title{
CAMPHILL AND THE FUTURE
}

\section{Spirituality and Disability in an Evolving Communal Movement}

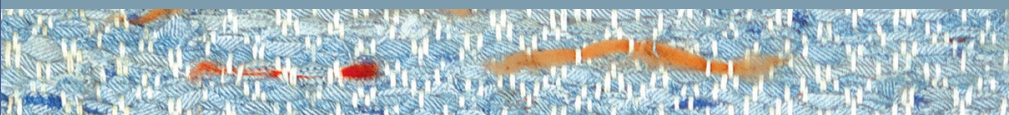

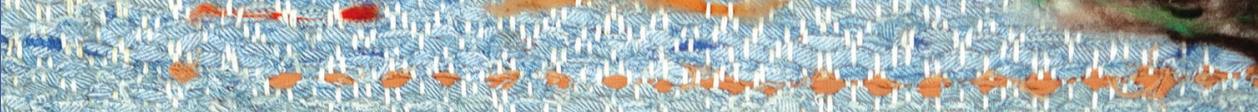
3.

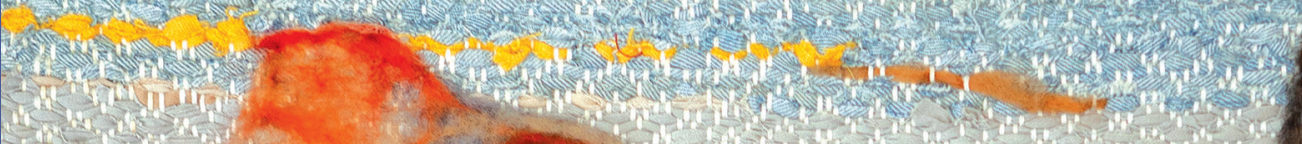
a
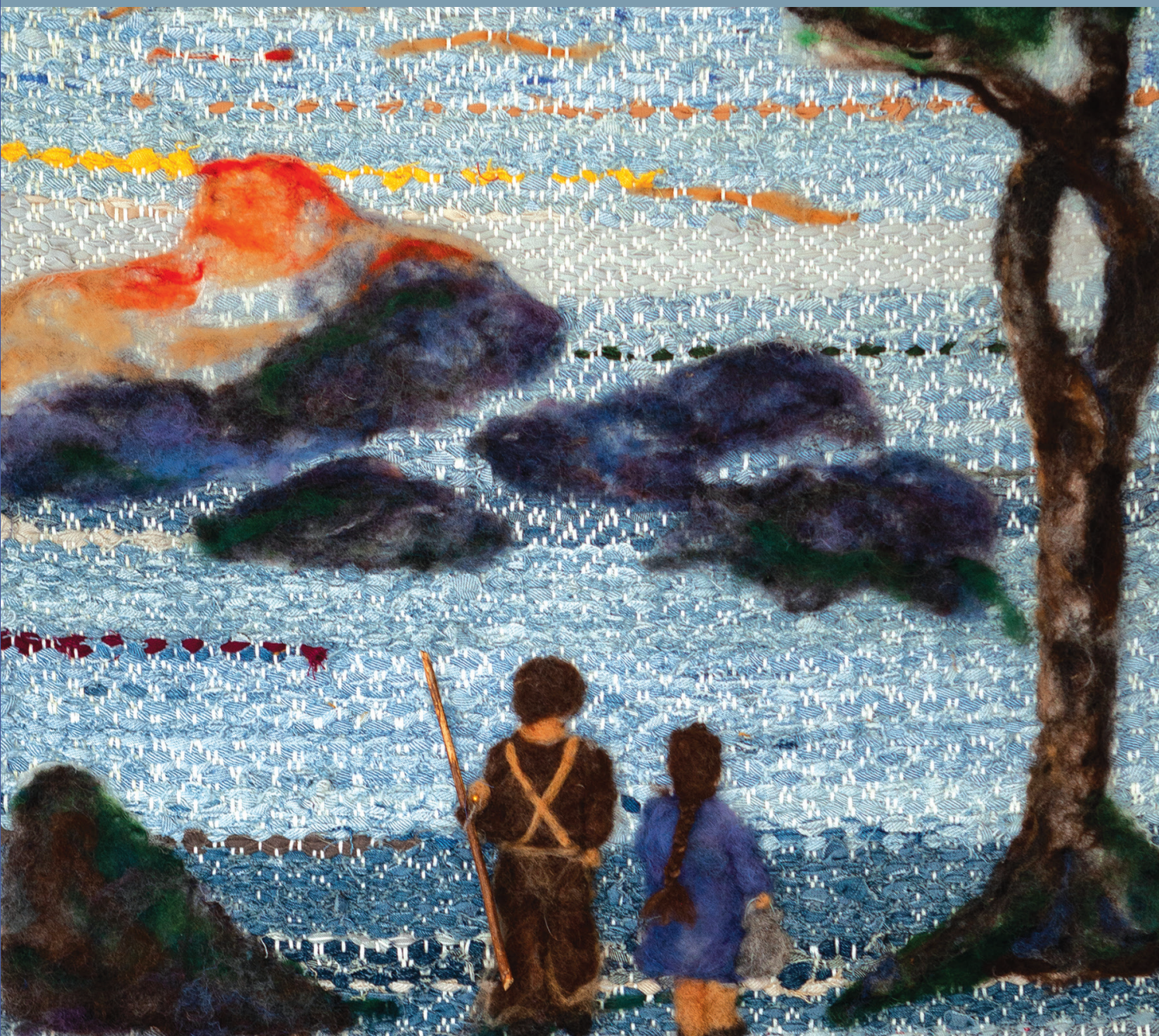

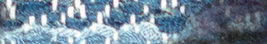

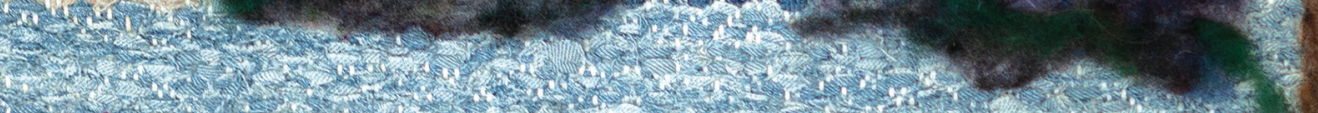

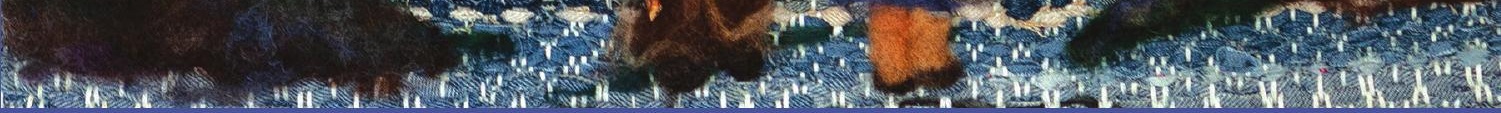

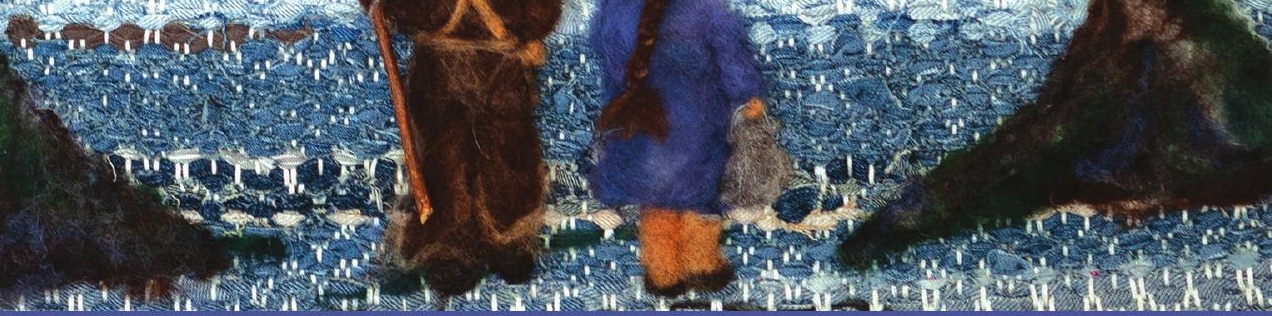


Luminos is the Open Access monograph publishing program from UC Press. Luminos provides a framework for preserving and reinvigorating monograph publishing for the future and increases the reach and visibility of important scholarly work. Titles published in the UC Press Luminos model are published with the same high standards for selection, peer review, production, and marketing as those in our traditional program. www.luminosoa.org 

Camphill and the Future 



\title{
Camphill and the Future
}

Spirituality and Disability in an Evolving

Communal Movement

\author{
Dan McKanan
}

\section{प}

UNIVERSITY OF CALIFORNIA PRESS 
University of California Press

Oakland, California

(C) 2020 by Dan McKanan

This work is licensed under a Creative Commons [CC BY-NC-ND] license. To view a copy of the license, visit http://creativecommons.org/licenses.

Suggested citation: McKanan, D. Camphill and the Future: Spirituality and Disability in an Evolving Communal Movement. Oakland: University of California Press, 2020. DOI: https://doi.org/10.1525/luminos.92

\section{Library of Congress Cataloging-in-Publication Data}

Names: McKanan, Dan, author.

Title: Camphill and the future : spirituality and disability in an evolving communal movement / Dan McKanan.

Description: Oakland, California : University of California Press, [2020] | Includes bibliographical references and index.

Identifiers: LCCN 2020014490 (print) | LCCN 2020014491 (ebook) | ISBN 9780520344082 (paperback) | ISBN 9780520975354 (ebook)

Subjects: LCSH: Camphill Movement-History-2oth century. | Camphill Movement-History-21st century. | People with mental disabilities-Religious aspects. | Anthroposophical therapy.

Classification: LCC HV3004.M335 2020 (print) | LCC HV3OO4 (ebook) | $\operatorname{DDC}_{362.3 / 8}$ - dc23

LC record available at https://lccn.loc.gov/2020014490

LC ebook record available at https://lccn.loc.gov/2020014491

$\begin{array}{llllllllll}29 & 28 & 27 & 26 & 25 & 24 & 23 & 22 & 21 & 20\end{array}$

$\begin{array}{llllllllll}10 & 9 & 8 & 7 & 6 & 5 & 4 & 3 & 2 & 1\end{array}$ 
CONTENTS

Acknowledgments

Introduction

A Visit to Camphill

Camphill Worldwide

1

Camphill Past and Future

Camphill and the Scholars

Many Paths to the Future

1. Camphill Generations

The Founders

26

Those Who Came

35

The Boomers

A Missing Generation

The Fourth Generation

2. Camphill Constituencies

Students and Villagers

Lifesharing Coworkers

Young Coworkers

Employees

Parents

Board Members 
3. Camphill Contexts

The Anthroposophical Movement

Other Communal Movements

161

Environmentalism

170

Social Care in an Age of Austerity

175

Disability Rights

187

Camphill Crises and Renewal

Conclusion

205

Notes

209

Index

231 
I have accumulated many debts in the twenty years I have spent studying Camphill. My greatest gratitude is for the people of Camphill Village Minnesota. They welcomed me in 1999 as a young professor who wasn't quite sure if I was looking for a research topic or a garden to weed. Many people who befriended me that summer have since died, among them Jerry, Danny, Jan, Trudy, David, and Evelyn. I hope that a small measure of their kindness will live on in the pages of this book.

The people who welcomed me to other Camphills are too numerous to name. My spouse, Tammy, and daughter, Oriana, accompanied me on long sojourns through Camphill places in Scotland, Ireland, England, Canada, and Norway. Hundreds of people cooked meals for us, prepared guest rooms, and allowed us to work alongside them in gardens, kitchens, and workshops. Others welcomed me to Camphill places near Lake Constance and in the Netherlands. Both I and my students have enjoyed the hospitality of Heartbeet Lifesharing, Camphill Copake, Triform Camphill Community, Camphill Ghent, Camphill Hudson, Camphill Special School (Beaver Run and Beaver Farm), Camphill Village Kimberton Hills, and Camphill Soltane on many occasions, most recently the festive gathering of the International Communal Studies Association at the New York communities in summer 2019. I am grateful to Harvard's Center for the Study of World Religions for a grant that made some of these journeys possible, as well as to the Divinity School for supporting research leaves in the 2013-14 academic year and the spring of 2018.

My understanding of Camphill and of intentional communities has been enriched by colleagues in both the academy and the community movement. I presented many sections of this book at meetings of the Communal Studies Association, International Communal Studies Association, American Academy of 
Religion, Unitarian Universalist Collegium, North American Religions Colloquium at Harvard, Camphill Research Symposium, Biodynamic Association, and the Anthroposophic Council for Inclusive Social Development, and I thank the many friends and colleagues who shared their experiences and insights with me. I am also grateful to Eric Schmidt of the University of California Press for his consistent championing of scholarship on anthroposophy, to my two anonymous peer reviewers, and to the Press's dedicated editorial, production, and marketing professionals.

Finally, I wish to thank every person who is quoted in this book, as well as the people whom I interviewed but did not quote. Each of you gave a piece of your own life to make this book possible. I hope my words are a fitting testament to the devotion and creativity that you have shared with Camphill. 


\section{Introduction}

\section{A VISIT TO CAMPHILL}

Each year I bring students from Harvard University to a Camphill community - usually, either Camphill Village USA in Copake, New York, or Heartbeet Lifesharing in Vermont. At Camphill my students encounter a social world that is different from their own. We travel from the busy streets of Cambridge to dirt roads and mountain valleys, where our passage may be blocked by a herd of cows making their leisurely way to the milking barn. Camphill houses have a unique architectural style, with few right angles and lots of whimsical art. Each house is home to as many as a dozen people-families with children, young volunteers, elders-and the houses are interspersed with craft workshops, chapels, performance halls, and gardens. People walk easily from home to work to church to artistic performances that sometimes feature world-class performers. Meals open with sung prayers that are familiar to the Camphillers and unknown to my students. The students must learn the subtle customs of Camphill-a napkin in a ring, for example, signals the usual place of one of the house's residents, while a napkin folded flat signals a space available for a guest. They learn, sometimes with difficulty, that they should not leap up after a meal to help wash the dishes. Every task is already assigned to someone who performs it with pleasure and pride, and the visitor's role is to wait for someone to offer tea and conversation. My students learn that Camphill is a community suffused with intentionality: its daily rhythms keep everyone in physical and emotional balance; its gardens and farms keep humans, animals, and plants in creative contact; its economy and decisionmaking structures are designed to honor the integrity of every person.

My students also learn that Camphill places are shaped by a distinctive spirituality. The clues are subtle and ubiquitous. Interior walls in Camphill buildings are often painted using the "lazure" technique, in which multiple colors are applied in very thin layers to create rhythmical variations of hues. Reproductions of classical 
Christian art abound, with Raphael's Sistine Madonna a favorite. Even more common are "wet on wet" watercolor paintings, many depicting the "elemental beings" associated with earth, water, air, and fire. Many communities include a chapel designed for services of a tiny denomination called the Christian Community; others have "halls" suitable for both religious services and artistic performances. Visiting such a hall, we may see Camphillers practicing "eurythmy," a form of spiritual movement that is used therapeutically and artistically. Outdoors, my students visit "healing herb" gardens full of medicinal plants, and observe cows whose horns have not been removed-both out of respect for the cows' bodily integrity and because some Camphillers believe that cowhorns help channel cosmic forces to earth. If we visit in the summer or fall, we may hear about a St. John's or Michaelmas festival, seasonal celebrations that Camphillers observe as devotedly as Christmas and Easter. We may also hear about plays or conferences devoted to such personalities as Faust, Parsifal, or Kaspar Hauser-the last a nineteenthcentury German youth who claimed to have been raised entirely in a dark cell. All of these distinctive features of Camphill life reflect the fact that the movement's founders were inspired by the "anthroposophical" spirituality developed by Rudolf Steiner (1861-1925). Yet our tour guide may not be able to offer a full explanation of any of them, because committed students of anthroposophy represent only a minority of Camphillers today.

What my students do not meet at Camphill are starry-eyed utopians certain that they've found the true path for all humanity. Nor do they encounter passive inmates whose individuality has been stolen by an institution. Instead, they meet people who are, simply, at home. Camphillers, many of whom have been identified as developmentally or intellectually disabled by a society prone to ranking people by ability, are experts in the arts of homemaking and hospitality. They have created communities that are beautiful, purposeful, and rhythmical because they have discovered that these qualities help people of all abilities feel at home. Rather than providing special accommodations to allow persons with disabilities to participate in a society that was not designed for them, Camphill builds an entire lifestyle around their distinctive gifts and needs, and then invites the so-called nondisabled to accommodate themselves to it. ${ }^{1}$ Those who have been labeled as disabled are usually the most seasoned Camphillers, and they take the lead in welcoming visitors to their space. They take pride in honoring the breakfast preferences of overnight guests, show off their vegetable and herb gardens, and offer tours of the workshops where they bind books, pour candles, weave carpets, and make beautiful jewelry and stained glass. They are quick to ask questions. "Where are you from?" "Do you go to school?" "What do you study?" "Do you know my sister Siobhan? She lives in Cambridge too!"

Secure in their sense of home, many Camphillers are proud of the progress they have made toward a truly nondisabling society. At the same time, some inform visitors that Camphill falls short of its ideals or has declined from a more idealistic past. Some think that Camphill's greatest weakness is its idealistic separation from 
the larger society; others worry that it has made too many compromises with social care bureaucracies. Some believe that Camphill's loosening relationship with anthroposophy will deprive it of the fruits of spiritual striving; others believe that full inclusion requires even less spiritual specificity. All know that their movement is changing rapidly as it approaches its hundredth anniversary.

Most Camphillers agree that their movement aspires to be a "seed of social renewal." This means helping all people, regardless of ability, live in ways that are less disabling for others. It also means helping everyone work for the benefit of others, while trusting that others will in turn work for their benefit. And it means fostering harmony between human communities and more-than-human ecosystems. To achieve these goals, a Camphill community must be neither an institution nor a utopia. Institutions perpetuate patterns of disablement by locking people into fixed roles, most notably the roles of "caregiver" and "care recipient." Utopias offer abstract blueprints for social renewal that are disconnected from individuals' diverse identities and aspirations-as, for example, friends or lovers or parents or artists or farmers. For persons who have been excluded from the ordinary goods of society, utopia's promise to replace those goods with something wholly new is both risky and unappealing. People who have been marked as disabled need communities that will help them gain access to the goods of the mainstream society, and simultaneously empower them to resist those aspects of mainstream society that contribute to disablement. Camphill is well positioned to avoid the dangers of both institution and utopia because it has been evolving in complex relationship with its neighbors for four generations.

It has not been evolving alone. Other communal movements with roots in the early twentieth century, such as Israel's kibbutzim and the Catholic Worker movement, face the same developmental challenges as Camphill. Earlier movements have faced these challenges in the past. Some navigate between the abstract illusions of utopia and the concrete constraints of institutionalization by evolving beyond community, lowering the boundaries between themselves and their neighbors. Others evolve in creative symbiosis with their neighbors, building bridges that inspire those neighbors to invest in the preservation of communal practices. Whichever path Camphill chooses, its future will shed new light on the capacity of spiritually inspired communities to foster a society that is truly nondisabling.

\section{CAMPHILL WORLDWIDE}

If my class had the means to visit the other 120 places that constitute the worldwide Camphill Movement, they would meet other people, equally at home in places with much in common and many differences. If we were to visit the Lehenhof in Germany, we could travel by city bus to a village square with its own lively bus stop. Regular buses keep Lehenhof's 270 residents connected to the city of Überlingen, which lies far below Lehenhof on the shores of Lake Constance. We would be greeted by the smell of fresh bread from a bakery that is so productive 
that many neighbors associate the name "Lehenhof" with bread rather than with disability or intentional community. The bus would take us to gardens and craft workshops much like those at Copake and Heartbeet, to a dairy barn with a milking herd of fifty cows, and to a factory where workers package and label ecological cleaning products for a company called Sonett. We'd continue to the Lehenhof grocery store, which is not located within the bounds of the community at all but in the neighboring town. It provides organic vegetables and socially responsible products to hundreds of townspeople.

The boundary between intentional community and ordinary town is even blurrier in Callan, Ireland, where the Kilkenny Collective for Arts Talent (KCAT) is located in a bustling town center. KCAT is not a residential community but an art center that offers studio spaces, a theater troupe, and classes to persons with disabilities "and other disadvantages." Founded in 1999 with support from the European Union, KCAT maintains a high profile in its local community by sponsoring arts festivals for its neighbors.

Camphill Soltane is equally prominent in the town of Kimberton, Pennsylvania, where it maintains an art center similar to KCAT, a café, a restaurant, a fabric arts store, a nursery for organic plants and garden products, and several residential households. The focus on socially responsible enterprises represents a significant transformation of Soltane's original identity. The community also has a bucolic residential campus, twelve miles from town, with abundant gardens and craft workshops. Soltane deliberately shifted its center of gravity away from that location because its residents wanted to participate more fully in society.

Camphill's work in India, which began in the 1990s, reflects a similar yearning for social connection. Sadhana Village, near Mumbai, relies mostly on local workers rather than the international volunteers who are prominent at other Camphills. Its work with people with learning difficulties is a springboard for a broader program of rural empowerment focusing on education, agriculture, and women's rights. A residential community exists alongside a school for local children, as well as papermaking, candlemaking, and carpentry workshops. Starting with the families of people with disabilities, they have helped two hundred families construct toilets, and have helped build five irrigation projects and three water conservation projects. ${ }^{2}$ Similarly, "Friends of Camphill India" in Bangalore is located on a Hindu ashram that also maintains a senior citizen home. The community incorporates yoga into its daily rhythm and celebrates festivals that blend Camphill's European roots with local traditions. At the community's fourteenth anniversary, for example, the Parzival play was presented as an example of the "inner jihad" or "inner Kurukshetra" of any person seeking transformation. ${ }^{3}$

All Camphills, whether immersed in or set apart from surrounding neighborhoods, strive to create supportive and cooperative homes for people of diverse abilities. All are changing rapidly, in tandem with vast changes in the ways Western societies treat persons identified as "disabled." Camphill was born at the height of 
"institutionalization," when people with different ways of thinking and learning were segregated in large facilities, often without access to the larger society or their own families. In that context, Camphill was an experiment in radical inclusion, since its nondisabled "coworkers" ate the same meals, slept under the same roofs, and educated their children in the same schools as the young people they supported. Camphill's success helped foster the "deinstitutionalization" movement of the 1970 and the rise of an activist disability rights movement. From that movement's perspective, Camphills may look like "institutions" that must be shut down in order to integrate their residents into ordinary neighborhoods. Camphillers reply that what they offer is actually a model of "reverse integration." Though this vision is clear, Camphillers have diverse ideas about how to embody it.

In its evolving relationship with society, Camphill is similar to other communal movements that are approaching their hundredth anniversary. A developmental trend away from communal isolation toward symbiotic interaction is not unique to communities that welcome people who have been marked as disabled. It is a common feature of the Israeli kibbutzim, the Catholic Worker movement in the United States, and other communal movements that were born during the global crisis of the 1930s. The kibbutz movement in particular has shed many of its original boundaries, in a process that some perceive as renewal and others as betrayal. Social engagement rather than isolation is also an aspiration of communal movements founded more recently, above all the rapidly growing cohousing and ecovillage movements. Collectively, the diverse experiences of intentional communities founded in the twentieth century empower us to think in new ways about the gifts that communities can offer humanity. Camphill is one chapter in a larger story.

This book, likewise, tells just one of many Camphill stories. I discovered Camphill in 1998, when I began teaching at a college that is fifty miles from Camphill Village Minnesota, with a bike trail covering most of the intervening distance. Because I was interested in intentional community, I spent roughly three months (in three successive summers) as a full-time resident of that community, and have since visited dozens of other Camphills in the United States, Canada, Scotland, Ireland, England, Norway, and Germany. I have also become part of the quirky and inspiring community of communal studies scholars, learning from them about diverse experiments in cooperative living both past and present. Camphill has not always been included in accounts of communal history, and I hope to rectify that omission. Neither Camphill's roots in the anthroposophical spirituality of Rudolf Steiner nor its emphasis on disability contributed to my initial interest in the movement, yet I have come to see how essential both of these factors are to its communal vision. Most of what communal studies can learn from Camphill flows directly from the confluence of anthroposophy and disability. I hope that my Camphill story will be of interest and value to students of Rudolf Steiner and to persons who have experienced disablement, yet I also recognize that those people may see things in Camphill that I cannot. 


\section{THE GEOGRAPHY OF CAMPHILL}

One hundred twenty Camphill communities are located in Europe, Africa, North America, and Asia. They are loosely organized in seven geographical regions: Scotland, England and Wales, Ireland, Central Europe, Northern Europe, North America, and Southern Africa. Each region has a distinctive set of structures for cooperation.

\section{THE SCOTTISH REGION}

Scotland: Camphill School Aberdeen (1940), Newton Dee (1945; became village in 1960), Ochil Tower School (1972), Milltown Community (1974), Blair Drummond (1976), Beannachar (1978), Corbenic (1978), Loch Arthur Community (1984), Simeon Care for the Elderly (1984), Tigh a'Chomainn (1987), Tiphereth (1993)

Cooperative Structures: Camphill Scotland is a membership body that serves the separately incorporated Camphill communities in Scotland.

\section{THE ENGLISH AND WELSH REGION}

England: Thornbury Sheiling School (1948), Ringwood Sheiling School (1954), Botton Village (1955), The Grange (1961), Delrow Community (1963), Stourbridge Houses (1968), Mount Community (1971), Croft Community (1974), Pennine Community (1977), Cherry Orchards (c. 1977), Camphill Milton Keynes (c. 1977), Oaklands Park (1978), William Morris House (1978), Devon Community (1979), Gannicox Community (1979), The Hatch (became independent from Thornbury in 1983), Sturts Community Trust (1983), Larchfield Community (1986), Thornage Hall (1989), Taurus Crafts (1995), Saint Albans Community (1997), Lantern Community (1997), Orchard Leigh (became independent from William Morris in 2013), Shared Lives Dudley (2018), Esk Valley Camphill Community (2018)

Wales: Coleg Elidyr (1973), Victoria House (1981), Glasallt Fawr

Cooperative Structures: Camphill Village Trust is a single charity that owns ten villages and town communities serving adults with special needs. Camphill England and Wales is a network that supports all Camphill places in England and Wales. The Association of Camphill Communities in the UK and Ireland facilitates mutual support among Camphill communities in the UK and Ireland. The Alliance for Camphill is an advocacy organization that promotes traditional lifesharing.

\section{THE IRISH REGION}

Republic of Ireland: Duffcarrig (1972), Ballytobin (1979, no longer affiliated), Dunshane (1985), Grangemockler (1986), Kyle (1987), The Bridge (1992), Bally Bay (1993), Thomastown (1993), Carrick-on-Suir (1996), Journeyman (1998), KCAT (1999), Callan (2001), Dingle (2004), Grangebeg (2006), Ballymoney (2008), Greenacres, Jerpoint

Northern Ireland: Glencraig (1953), Mourne Grange (1971), Clanabogan (1984), Holywood (1996) 
Cooperative Structures: Camphill Communities of Ireland is a single charity that owns all of the communities in the Republic of Ireland. Camphill Communities Trust (NI) is a support network that serves the separately incorporated Camphill communities in Northern Ireland.

\section{THE CENTRAL EUROPEAN REGION}

Germany: Brachenreuthe School Community (1958), Föhrenbühl School Community (1963), Lehenhof Village Community (1964), Bruckfelden School Community (1966), Karl König School Nürnberg (1973), Thomas House Berlin (1975), Hermannsberg Village Community (1976), Hausenhof Village Community (1987), Königsmühle Life Community (1990), Alt-Schönow Life Community (1990), Sellen Village Community (1992), Markus Community Hauteroda (founded 1973, joined Camphill 1999)

Netherlands: Christophorus (1954), Het Maartenhuis (1980), De Noorderhoeve (1981), Orion Community (1994), Gezinskring 't Huys (2002)

Poland: Wójtówka (1996)

Switzerland: Fondation Perceval (1965), Stiftung Humanus-Haus (1973)

Austria: Liebenfels (1976)

France: Le Beal (1977)

Czech Republic: Camphill České Kopisty (1998)

Hungary: Camphill Magyaraországi Velem (2007; operations currently suspended)

\section{THE NORTHERN EUROPEAN REGION}

Finland: Sylvia-Koti (1956), Tapolan Kylayhteisö (1974),Myllylähde (1989), Kaupunkikyla (2006)

Norway: Vidaråsen (1966), Hogganvik (1972), Solborg (1977), Jøssåsen (1978), Vallersund (1981), Rotvoll (1989)

Sweden: Staffansgården (1974), Häggatorp (2003)

Russia: Camphill Svetlana (1993), Tourmalin (2003), Camphill Chisty Klyuchi (2012)

Estonia: Pahkla Camphilli Küla (1992)

Latvia: Rozkalni (1999)

Cooperative Structures: Camphill Village Trust of Norway is a single charity that owns all of the communities in Norway.

THE NORTH AMERICAN REGION

United States: Camphill Special School (Beaver Run, 1961), Camphill Village Copake (1961), Camphill Village Kimberton Hills (1972), Triform Camphill Community (1977), Camphill Village Minnesota (1980), Camphill Soltane (1988), Camphill California (1998), Heartbeet Lifesharing (2006), Camphill Hudson (2007), Camphill Ghent (2012), Plowshare Farm (2015) 
Canada: Camphill Communities Ontario (1986), Cascadia Society (1990), Glenora Farm (1993)

Cooperative Structures: Camphill Association of North America is a membership body for the separately incorporated communities in this region. Camphill Foundation is a fundraising body. Camphill Academy provides communitybased college and graduate education for coworkers.

THE SOUTHERN AFRICAN REGION

South Africa: Hermanus Camphill School (1952), Camphill West Coast (1964, previously known as Alpha), Camphill Farm Community Hermanus (1978)

Botswana: Camphill Botswana (1974)

\section{CAMPHILLS BEYOND THE REGIONS}

India: Sadhana Village (1989), Friends of Camphill India (1995)

Vietnam: Peaceful Bamboo Village (2009)

Additional countries with communities that are contemplating membership in the Camphill movement: Columbia, Kenya, Lithuania, Rwanda, Sri Lanka, South Korea, Thailand

GLOBAL COOPERATIVE STRUCTURES

An Asian Region is currently under development. The Karl König Institute maintains the Karl König Archive and the Camphill Archive (both in Aberdeen, Scotland) and publishes works by and related to Karl König. The Camphill Research Network maintains a repository of academic and community-based research related to Camphill.

\section{CAMPHILL PAST AND FUTURE}

More than 120 villages, schools, and other communities comprise the worldwide Camphill Movement, and collectively they are home to several thousand people. ${ }^{4}$ Its founders were inspired by Rudolf Steiner, who in turn was active in the Theosophical Society before creating his own movement known as anthroposophy. Anthroposophy is difficult to describe, in part because Steiner was both a dizzyingly complex spiritual teacher and the founder of multiple practical "initiatives." Most Camphillers, and most participants in other anthroposophical initiatives today, do not personally subscribe to Steiner's core spiritual teachings, and initiative participants collectively outnumber members of the Anthroposophical Society, most of whom are committed to Steiner's spirituality. From an external perspective, the initiatives represent the more important dimension of Steiner's legacy, yet they cannot be fully understood apart from the spirituality that informs them. 
Steiner defined anthroposophy as "a path of knowledge aiming to guide the spiritual element in the human being to the spiritual in the universe."5 From my own perspective, the leading feature of anthroposophy is its emphasis on balance: balance between the human and the cosmic, between spiritual traditions of East and West, between ancient wisdom and the scientific research methods of the modern West. ${ }^{6}$ In the "basic books" that are often recommended to newcomers to anthroposophy, Steiner identified the multiple spiritual bodies possessed by each human being, described the cosmic forces that have guided human evolution on multiple planets, offered an esoteric interpretation of Christianity, and suggested techniques for developing the supersensory powers needed for "spiritual research."7 In his interactions with members of the Anthroposophical Society, he shared mantralike "verses" and helped them understand the karmic implications of past lives. Many scholars of religion regard Steiner's teachings as a repackaging of Helena Blavatsky's theosophy, with relatively more emphasis on her original Western esoteric sources and relatively less emphasis on the Eastern vocabulary she adopted in the latter part of her career. ${ }^{8}$ Anthroposophists typically downplay Blavatsky's influence, pointing to Steiner's own assertion that he did not teach anything that he had not validated through his own spiritual research. ${ }^{9}$ They also note that he admonished his students to take nothing on faith, but to embrace only what resonated with their own experience.

The best-known of Steiner's practical initiatives is the Waldorf system of education, which seeks to nurture the spirit, soul, and body of each student through an experiential pedagogy that emphasizes hands-on learning, artistic creativity, and encounters with nature. A close second is biodynamic agriculture, which treats each farm as a living organism, uses homeopathic and alchemical practices to nurture the soil, and rejects chemical fertilizers and pesticides. ${ }^{10}$ Camphill is much smaller than those two movements, and represents less than half of anthroposophical work supporting persons with learning difficulties. It is distinctive, though, in its effort to combine features of multiple initiatives within a single social organism. Camphill schools follow the Waldorf curriculum, Camphill farms and gardens use biodynamic methods, and Camphill clinics practice anthroposophical medicine, which combines mainstream and homeopathic therapies with a strong emphasis on the healing bond between doctor and patient. Camphill chapels host the rituals of the Christian Community, a Steiner-inspired "movement for religious renewal" whose liturgies seek to reveal the inner meaning of Christian tradition. Camphill buildings follow Steiner's architectural principles, mirroring organic forms through the avoidance of right angles. Camphills celebrate an annual cycle of festivals that reflect Steiner's understanding of the connection between Christianity and the cycles of the natural world. Distinctively anthroposophical art forms are central to Camphill life. And Camphill communities strive to embody what Steiner called the "threefold social order," in which spheres of economic, political, and cultural activity are autonomous but interrelated. 
Camphill was born in Scotland between 1938 and 1940. Its founders were refugees from Nazi-occupied Vienna. Most were Jewish; all were spiritual students of Rudolf Steiner. Most were interested in Steiner's method of "curative education" for children with disabilities, though only one was formally trained as a teacher. Others had studied medicine, nursing, chemistry, dance, and art. By taking on the task of creating a residential community for children with special support needs, they drew on the resources not only of anthroposophy but also of the Moravian Christianity in which cofounder Tilla König had been raised. Moravians, whose own roots stretched from the work of the fifteenth-century Czech reformer Jan Hus to eighteenth-century German Pietism, maintained a central European network of residences for people who had been deemed disabled by the larger society. Tilla König was not the only early Camphiller to have experienced the Moravian model of disability-centered community.

Both the children and their refugee caregivers had, in a sense, been cast out from society, and this helped them form a strong bond. But separation from society was never the goal. Camphillers hoped, rather, to revive the European cosmopolitanism that had been destroyed by Hitler. And they were not without friends in the larger society. Wealthy families helped them obtain several estates, among them the Scottish property known as "Camphill" and the former summer home of a British family prominent in publishing and politics. The interplay between the Camphillers' ideals and the sympathy of their friends ensured the survival of the new movement. With each subsequent generation, that interplay became more complex. At the end of World War II, the founders welcomed a new wave of refugees into the movement, and paved the way for educational inclusion by creating a school to educate both children with special needs and the children of the caregivers. In 1955, with the founding of Botton Village, they created a new form of village life for adults with special needs. Amid the upheaval of the 1960 , they made room for baby boomer idealists, spiritual seekers, and hippies. They then followed the lead of adults with special needs who wanted to bring Camphill out of its rural isolation and into urban spaces. Today, Camphill is making a transition to a fourth generation, in which incomesharing communitarians, shortterm volunteers, employed staff, nonresident participants in day programs, board members, parents, and neighbors are all creating community together.

It is a time of hope and trepidation. Since the turn of the twenty-first century, Camphill has expanded to new countries on four continents and deepened its emphasis on urban living and community-based care for elders. Many Camphill places are environmental innovators, hosting natural wastewater treatment, biomass or biogas power systems, and solar arrays. Yet it is not uncommon to hear Camphillers complain that their movement is dying, and repeating the unsubstantiated story that founder Karl König had predicted the movement would die out in the twenty-first century. ${ }^{11}$ At eighty years of age, it is perhaps natural that a community movement would be conscious of its own mortality. 
When Camphillers predict their movement's demise, they are mostly expressing a fear that it is abandoning its distinctive cooperative features. Notable among these are two practices that I will refer to as "incomesharing" and "lifesharing." In traditional Camphills, people work without salaries and rely on the community for their economic needs, honoring a principle of economic cooperation that Rudolf Steiner called the "fundamental social law." Likewise, people of diverse abilities and ages occupy households in which meals, recreation, religious services, and seasonal festivals are all shared. Camphill founder Karl König was referring primarily to incomesharing and lifesharing when he declared that "the establishment of a true community" was one of the three "Camphill essentials," along with "regard for the spiritual nature" of persons with disabilities and commitment to "inner development" on the part of their companions. Many Camphillers still regard these as definitive marks of the community. "The idea is that we don't get paid for what we do, we get paid what we need to live," said Jonny Mallam-Clarke, a coworker I met at Camphill School Aberdeen. "That was important for the founders of the community. And I think it is still important for a lot of people now." ${ }^{12}$

König's declaration notwithstanding, incomesharing and lifesharing are by no means considered "essential" by every Camphill community today. More and more people participate in Camphill life as employees, day students, or sheltered workshop participants who live offsite. Though the total number of people involved in Camphill is still increasing, the number of long-term, nondisabled Camphillers who participate in both incomesharing and lifesharing is in decline. This is both a source of concern and an opportunity for Camphill to renew König's founding vision of "true community." For the "Camphill essentials," he acknowledged, were not fixed rules but "fruits and flowers" that would need to "unfold and grow" in order for Camphill to achieve its potential. ${ }^{13}$

\section{A CAMPHILL TIMELINE}

1861 Rudolf Steiner was born in Kraljevec, Croatia (then part of the AustroHungarian Empire).

1886 Steiner began developing ideas about curative education while working as a tutor for Otto Specht, a boy suffering from hydrocephaly.

1902 Karl König was born in Vienna, Austria. Matilda (Tilla) Maasberg was born in Silesia, then part of Germany.

1912 Steiner established the Anthroposophical Society after a decade of activity in the German section of the Theosophical Society.

1920 Steiner offered his first lecture series for medical doctors.

1923 Steiner's associate Ita Wegman began working with children with intellectual disabilities. 
1924 Anthroposophists in Jena, Germany, opened the Lauenstein, a home for children with special needs.

Rudolf Steiner delivered his lecture series on "Curative Education" at the Lauenstein.

1925 Rudolf Steiner died in Dornach, Switzerland.

1927 Ita Wegman offered a course on curative education at the newlyestablished Sonnenhof in Arlesheim, Switzerland. Both Karl König and Tilla Maasberg participated.

1929 Tilla Maasberg and Karl König were married while working at the Pilgramshain curative center in Silesia.

Hans Schauder, Lisl Schwalb (later Schauder), Rudi Lissau, Alex Baum, Sali Gerstler (later Barbara Lipsker), and Trude Blau (later Amann) participated in an anthroposophical youth group in Vienna.

1935 The General Anthroposophical Society expelled Ita Wegman and Elisabeth Vreede from its executive council, and severed relations with its British and Dutch branches.

1936 Karl and Tilla König left Pilgramshain and settled in Vienna, where Karl organized a youth group that included Peter Roth, Alix Roth, Thomas Weihs, Carlo Pietzner, and Marie Korach. Anke Nederhoed (later Weihs) and Willi Amann met members of the group at this time.

1938 Austria was annexed to Nazi Germany, forcing the Königs and members of the youth groups into exile. They agreed to regroup in order to continue their shared work, and many arrived in Scotland by the end of the year.

1939 Camphill's founders began their common work at Kirkton House in northern Scotland.

1940 The female members of the founding group moved from Kirkton House to the Camphill estate west of Aberdeen. At this time, the men were interned as foreign nationals on the Isle of Man or in Canada.

1945 Karl König articulated the founding ideals of Camphill and its inner community in the First Memorandum.

1948 Camphill established a school for children with and without disabilities, and expanded to include the Murtle and Newton Dee Estates.

Camphill began work at Thornbury House in Bristol, England, and at Ringwood in Hampshire, England.

1949 Camphill's first Seminar in Curative Education began.

1953 Glencraig was established as the first Camphill center in Ireland.

1954 Christophorus was established as the first Camphill school in the Netherlands. 
1955 Botton Village was established as the first village community for adults with special needs.

1957 Hermanus was established as the first Camphill school in South Africa.

Karl König appointed Thomas Weihs as his successor at the original Camphill school and claimed a new role as chairman of the Camphill Movement.

1958 Brachenreuthe was established as Camphill's first school in Germany.

1961 Carlo and Ursel Pietzner arrived in the United States, where they transformed an earlier school into Camphill Special School in Beaver Run, Pennsylvania, and established Camphill Village USA in Copake, New York.

1964 Karl König relinquished his role as movement chairman and appointed six regional chairs.

1966 Karl König died at Brachenreuthe.

1968 Heathfield Cottage in England (later Stourbridge Houses) was established as Camphill's first town community.

1971 The Mount in Sussex, England, was established as Camphill's first training college.

1982 Ha Vinh Tho began work among children with special needs in Vietnam, after several years at Camphill Perceval in Switzerland.

1984 Simeon Care, near Aberdeen, was established as Camphill's first elder community.

1989 Sadhana Village began Camphill work in India with support of coworkers from Camphill Copake.

2008 The first graduate of Camphill Academy's baccalaureate program received his degree.

2009 Peaceful Bamboo Village formally opened as the first Camphill community in Vietnam.

2010 Camphill Vidaråsen renewed its commitment to lifesharing and incomesharing after more than a decade of conflict.

2014 Conflict erupted at Botton Village when longtime coworkers rejected the Camphill Village Trust's policies limiting lifesharing and incomesharing.

2017 Ireland's Health Service Executive took control of Camphill Ballytobin in response to allegations of abuse and conflict over lifesharing and incomesharing.

2018 A mediation agreement resulted in the formal separation of Esk Valley Camphill Community from the Camphill Village Trust. Both entities continued to maintain households at Botton Village. 


\section{CAMPHILL AND THE SCHOLARS}

By exploring the relationship between Camphill's past and its possible futures, I hope to hold up a mirror for participants in the Camphill Movement that will be useful to them. I also hope to inspire a long-overdue dialogue between the Camphill Movement and the disability rights movement, as well as between the academic fields of communal studies and disability studies. Yet I must be clear about the limits of my capacity to enact that dialogue within the pages of this book. I have participated in the community of communal studies scholars for two decades, but am new to disability studies. Likewise, I am neither a committed Camphiller nor a person with a disability. I have no standing to dictate the terms of dialogue between those two overlapping groups of people, but can only offer suggestions. Camphillers and disability rights activists who are intrigued by what I have to say should seek out additional dialogue partners to test the validity of my observations.

A deep dialogue between communal studies and disability studies has the potential to expand both fields' imagination about the future. Disability studies imagines something that has never quite existed: a world in which people with physical or mental impairments are not disabled by societal barriers and prejudices. Communal studies explores the long history of idealistic groups that have tried to imagine a new society into reality. Each episode in the history of communalism has the potential to shed light on the task of creating a nondisabling society. Yet disability studies also brings a keen awareness of the dehumanizing potential of social experiments that are set apart from the larger society. Again and again, disablement has been perpetrated by confining institutions that began as idealistic utopias. Communal studies scholars who refuse to face this can offer little to the dialogue.

A dialogue between the fields is overdue because Camphill began exploring and combating the social dimensions of disablement at least two decades before scholars who were also participants in the nascent disability rights movement articulated the "social model of disability" in the 1970s and 1980s. As early as 1956, Camphill founder Karl König identified the use of intelligence tests to segregate schoolchildren by ability as one of the three cardinal errors afflicting modern society, and proposed social reconstruction as a solution. ${ }^{14}$ Yet more than half a century later, Camphill's existence is seldom acknowledged by disability studies scholars, and Camphillers have only recently begun inviting those scholars to their own conferences and gatherings.

The lack of dialogue is not the fault of persons on either side of the divide. In part, it reflects the accidental fact that the two movements started at different times. Because the vocabulary of disability studies and disability rights was not available at Camphill's founding, Camphillers adopted different language to express similar ideas and did not consistently update their language. Their understanding of the 
social dimension of disablement did not instantly come with a recognition, so important to disability rights activism, that persons with disabilities themselves must play the leading role in shaping a nondisabling society-though in practice such persons were in fact shaping Camphill life. There are also genuine differences of worldview between the movements. The dialogue I hope for will not be characterized by instantaneous consensus, but by deep questioning and perhaps some degree of mutual conversion.

Disability rights activism and disability studies scholarship, for example, were shaped by Marxist models of societal oppression and by the identity-based social movements of the 1960 s and 1970s. Many disability scholars understand disablement as broadly analogous to patriarchy, white supremacy, and heteronormativity, and more than a few would add that these evils are "endemic to all capitalist societies" and cannot be eliminated without the elimination of capitalism itself. ${ }^{15}$ Camphillers would not necessarily disagree. Yet Camphill's underlying worldview is distinct from that of the New Left and is inimical to Marxism. The other two cardinal errors that König singled out were not racism and sexism, but Darwinian survival of the fittest and the belief that humans had invented God. He assumed that disablement was endemic to all materialist societies and that the antidote was a renewal of spirituality.

König also believed that the roots of disability were karmic as well as social, and herein lies a vexing challenge for my hoped-for dialogue. (It is so vexing, in fact, that many or most Camphillers today choose not to engage with this aspect of their own tradition.) Disability studies scholars typically contrast the social model of disability with two "individualist" models: a "medical model" that sees the root problem as individual disease and a "moral model" that traces disability either to individual sinfulness or to special spiritual gifts. ${ }^{16}$ At first glance, the use of karma to understand disability might seem to be an extreme case of the "moral model." Disability studies scholars who are also scholars of religion have often faulted other disability studies scholars for perpetuating antireligious (and, especially, antiJewish) stereotypes when they describe the moral model, but few if any of these scholars would venture to defend a karmic approach to disability. ${ }^{17}$

Yet the anthroposophical approach to karma is neither individualistic nor inclined to render moral judgments. The minority of Camphillers who choose to engage this aspect of their heritage believe that they have been drawn to Camphill because they share a karmic heritage with other Camphillers. This shared heritage entails a shared task, which some might identify as undoing structures of disablement that they may have created in previous lives. The diverse embodiments of people who live at Camphill all contribute to their shared capacity to contribute to a cosmic destiny. This way of thinking about disability makes for an intriguing contrast with some theologies of disability proposed by mainstream Christians. Rather than calling all people to fulfill a lofty destiny, these theologians are more inclined to treat disability as a sign of the vulnerability that is intrinsic to 
the human condition. Here, too, there is much room for dialogue, especially since most of these theologians are deeply concerned with the life of congregationssocial structures that have multiple similarities to intentional communities. ${ }^{18}$

Even with these clarifications, I do not anticipate that many disability studies scholars will incorporate König's understanding of karma into their theoretical toolkit. Anyone contemplating dialogue with Camphill should know that Camphillers themselves do not agree on its usefulness. By contrast, virtually all Camphillers agree that intentional communities can play an important role in overcoming structures of disablement. This point may vex disability studies scholars, for many of the same reasons that utopian socialists have always vexed orthodox Marxists. If one aims to change society through political mobilization, an intentional community that is home to a few hundred can seem, at best, like a distraction that siphons off the energies of idealists who might otherwise be manning the barricades. At worst, intentional communities may appear little different from the isolating institutions that perpetrate the most dehumanizing sorts of disablement. To the extent that Camphillers fail to root out institutional vestiges from their communities or to support the political mobilization of persons with disabilities, they probably do not deserve to be in dialogue with disability studies. But many Camphillers today are doing both of those things with great energy. So long as disabling structures remain intact, Camphill's communal antidote deserves consideration.

Camphill's contribution has much to do with the fact that it has never understood itself as a utopia set apart from the larger society, but as a "seed of social renewal." It is at this point that the field of communal studies enters the dialogue. Much recent scholarship in that field has also highlighted the symbiotic relationship between intentional communities and the surrounding society. Since 1975, scholars have connected through the Communal Studies Association and the International Communal Studies Association. Many of these scholars are indebted to Don Pitzer, the founding director of the Center for Communal Studies at the University of Southern Indiana, for offering an interpretive approach that he calls "developmental communalism." This approach assumes that all communities grow and change over the course of their history. Drawing on decades of study of communal movements in the United States and around the world, Pitzer observed that movements "that do not adjust their strictly communal efforts or adopt new organizational forms more suitable to changing internal and external conditions and the needs of rising generations can arrest their own development," while those that create "more pliable social, economic and administrative forms usually see their causes not only survive but flourish."19 Pitzer's model built on the insights of other communal scholars such as Donald Janzen, who argued in the first issue of Communal Societies that communities should not be studied in isolation but with an eye to the "interface ... between the communal society and the larger national society of which [it is] a part." ${ }^{\text {"o }}$ 
The insights of Pitzer and Janzen are especially relevant to communities that, like Camphill, actively seek to chart a middle path between utopia and institution. This group includes several movements that emerged from the traumas of the twentieth century and have endured longer than the classical utopias of Robert Owen, Charles Fourier, and Étienne Cabet, and rival the longevity of such religiously exclusive communities as Shakers, Harmonists, and Amana. What sets these communities apart from those predecessors is their refusal to draw a binary distinction between the "good" community and the "bad" society. To be sure, they criticize aspects of mainstream society and hope to create a different future. But they do not assume that the new society will emerge exclusively or even primarily from within the walls of their own communities. Instead, they join in broader currents of social renewal. The kibbutzim, for example, did not seek to displace the rest of Israeli society; they helped build a new nation and hoped to infuse that nation with cooperative and socialist values. Gandhian ashrams sought to free India from the political and cultural domination of Great Britain-and they inspired a cluster of urban ashrams in the United States designed to fight Jim Crow segregation. The Catholic Worker was part of a larger impulse to end war and foster a land-based, agrarian culture. Arthur Morgan, the intellectual ancestor of today's Fellowship for Intentional Community (an umbrella organization connecting hundreds of communities in the United States) was responsible for both the enduring intentional community of Celo and the rural electrification projects of the Tennessee Valley Authority. Camphill's founders similarly hoped that their cooperative venture would be one "seed of social renewal" alongside other efforts to restore the cosmopolitan culture of their childhood. They embraced the work of honoring the human dignity of persons with intellectual disabilities and, increasingly, of defending the dignity of the land on which they lived and worked. But at no point did they ask their neighbors to take sides for or against them. Indeed, as one Camphiller memorably put it, a Camphillian parliament could never be organized into two opposing sides: "It would be an octagon or something bananas with lots of different levels and you'd be able to move through it." ${ }^{21}$

Camphill's reluctance to take sides has been reinforced by the presence of persons with learning difficulties as a core constituency of every Camphill place. With a few exceptions, these Camphillers do not come to community because they have rejected mainstream society. Most want to participate in society as fully as possible! They want to live in homes shaped by the rhythms of family life; they want to do meaningful work that benefits the people around them; they want to receive support and help from people who are genuinely their friends; they want to pursue romantic and other relationships of their own choosing. Camphill promises to help them do all these things. To be sure, quite a few of the nondisabled Camphillers have strong ideas about which mainstream social practices (such as watching television) are inimical to human flourishing, and this can create tensions with disabled Camphillers who aren't similarly convinced. Yet the simple fact 
that different Camphillers have followed radically different paths to community life means that the movement is continually drawn into deeper interaction with its environment, and this effect has intensified as the larger society has become more welcoming of persons with disabilities.

Camphill's avoidance of a binary opposition between community and society is also shaped by Rudolf Steiner's anthroposophy. This is so for two reasons. First, anthroposophy prizes balance. One of Steiner's favorite paintings was Raphael's fresco School of Athens, in which Plato gestures up to heaven while Aristotle points down at the earth. Rather than pitting spirit against matter, students of Steiner seek their spirituality in the way they set a table, weave a rug, or turn a pile of compost. Second, because communal living is not an intrinsic character of anthroposophy as such, Camphillers have always had close ties to other people who share their interest in the work of Rudolf Steiner but choose to live out that interest in different ways. Though in most respects Camphill is quite different from monastic life, it has this in common with monasticism: both are communal expressions of spiritual movements that are not uniformly communal. The support of spiritually sympathetic outsiders has been essential to the longevity of monasticism, and it plays a similar role in the life of twentieth-century movements including the kibbutzim, the ashrams, and the Catholic Worker, as well as more recent arrivals such as L'Arche, which is the other major network of intentional communities supporting people with intellectual disabilities.

Because Camphill and other twentieth-century communal movements are not opposed to society as such, they have created symbiotic connections throughout their histories. These connections are a major reason for the longevity of twentieth-century communities, since they are more likely to have neighbors who are invested in their longevity. All communal groups, to be sure, have sold products to and borrowed money from their neighbors, but the twentieth-century groups have been much more likely than their predecessors to derive a significant share of their income from outright gifts. Donations of cash, land, and buildings have saved many communal groups, Camphill included, from an early demise. The resulting longevity of twentieth-century communities has, in turn, increased their connectedness. Almost every communal movement, even those that start out quite hostile to their neighbors, develops more complex connections with the passage of time.

It is too soon to know if the symbiotically connected communities of the twentieth century will endure as long as the equally symbiotic traditions of Christian and Buddhist monasticism. But the time is ripe to start asking the kinds of questions that can only be asked of communities that have already weathered multiple generational transitions.

\section{MANY PATHS TO THE FUTURE}

Developmental communal scholarship provides the essential framework for understanding the diverse paths of enduring communities, though the case of 
Camphill suggests some revisions of Pitzer's model. That model is especially relevant to movements, such as Mormonism, for which communalism was one phase within a longer history. In such cases, communal living provides a protective shell in the early history of a new religious or social movement, then is discarded when it becomes an obstacle to the movement's numerical growth. Such transitions can be deeply painful to movements, including Camphill, that regard communal living as an intrinsic value as well as a means to the realization of other values. Fortunately, a wide canvas of intentional communities suggests that multiple developmental paths are open to communal movements.

The most common path is that of the community that fails to foster sufficiently intense commitment to overcome economic challenges and personality clashes, and thus dissolves within a few years. The second most common path is taken by communities that achieve intense commitment through the charismatic leadership of their founders, but fail to sustain their cohesion after those founders' deaths. For communities that survive for three or more generations, three additional paths are possible.

The first is one by which the movement grows large enough to function as a self-enclosed society, with sufficient stability and internal diversity to allow its members to meet the full range of human needs without leaving the community. To my knowledge, the only communal movement to follow this path successfully is the Hutterites, who have endured for half a millennium and now have forty-five thousand members worldwide. This is not a viable path for Camphill, which has about a fifth as many participants spread across a much wider geography.

A second path might be called "evolving beyond community." In this path, a movement dissolves its specifically communal structures while continuing to pursue other defining ideals. Sometimes this process is gradual; more often, it includes one or more crises that force the abrupt termination of specific cooperative practices. (In the language of evolutionary biologists, communal evolution typically follows the pattern of "punctuated equilibrium," in which long periods of stability alternate with times of rapid change. $)^{22}$ This is the path emphasized in Pitzer's scholarship, and it can be observed to some degree in most enduring communal movements.

A final path, hitherto little noticed by communal studies scholars, is what I will call "creative symbiosis." Movements that follow this path extend the benefits of communal living to their neighbors and others who live outside, to the extent that those people become committed to the preservation of communal practice. The support of outsiders makes it easier for the people who live in community to preserve their practices without sacrificing other life goals. This was the path taken, most notably, by Christian and Buddhist monastic communities. Monastics offered a variety of spiritual and educational services to their neighbors, and in return the neighbors endowed monasteries, invited monastics to create schools and hospitals, and encouraged their children to pursue monastic vocations. A similar path has been taken by the kibbutzim, which grew up symbiotically with the 
state of Israel and within the socialist movement in that country, and are currently becoming more involved in providing education and housing to people who are not full kibbutz members.

It is far from certain which of these last two paths Camphill will take in the future. Camphill is "evolving beyond community" in the many places that have abandoned incomesharing and drastically reduced lifesharing. Some disability rights advocates, as well as policymakers influenced by the disability rights movement, insist that evolving beyond community is the only valid developmental path for Camphill, given the imperative of offering persons with disabilities full access to the larger society. In keeping with this perspective, some of the places that have evolved furthest from Camphill's communal heritage vigorously promote "selfadvocacy" for their disabled residents, who have more freedom than residents of traditional Camphills to incorporate television watching and other modern indulgences into their household rhythms. (Self-advocates are people with learning difficulties who speak up for their individual rights, and mobilize collectively for empowering policies.) Other Camphillers worry that if this trend continues, Camphill will lose its capacity to contribute to social renewal and become an uninteresting network of care homes and special education schools, as "institutional" as the asylums of the nineteenth century. These worries resonate with the concerns of the most radical disability studies scholars-especially those influenced by either Marxism or queer theory-who argue that policymakers' desire for "inclusion" and "normalization" fails to consider the degree to which disablement is intrinsic to contemporary capitalist society. ${ }^{23}$

At the same time, Camphill is deepening its symbiotic relationship with its neighbors by piloting environmental practices that then spread throughout society, by creating cafés, walking paths, grocery stores, and performance spaces that are open to the general public, by volunteering in the community, and by partnering with nearby social enterprises. In a few cases, Camphill neighbors as well as the family members of Camphill residents have mobilized politically to resist proposals to eliminate incomesharing and lifesharing. These activists hope that the twenty-first century will be a time of resurrection, when coworkers, villagers with disabilities, families, and neighbors unite to defend Camphill communalism against the excessively materialistic forces of bureaucracy and austerity. For these activists, the path between the Scylla of institutionalism and the Charybdis of utopia requires a deeper embrace of communal cooperation.

It may be that Camphill will evolve simultaneously in both directions, with some communities moving rapidly away from communalism while others find the partners they need to maintain their communal traditions. It may also be that the majority of Camphill places will somehow blend these developmental paths. The future is uncertain, which makes this an especially exciting moment to study Camphill. 
Whatever path Camphill takes, it will do so as a significantly more complex social organism than it was in its first generation. Every enduring communal movement starts with a tight-knit group of founders who somehow manage to hang together and to open their circle progressively to others. With each subsequent generation, the internal complexity of the movement increases, as people with new backgrounds, values, and beliefs create new ways of connecting with the community. Thus, the coworkers and students who founded Camphill gradually made way for the people I will refer to as villagers, young coworkers, employees, day program participants, board members, parents, and neighbors. This increasing internal complexity, in turn, increases the points of contact with the larger society. The ecology of Camphill at its founding consisted primarily of the anthroposophical movement, the parents of children with disabilities in Scotland and England, and the crisis of World War II. Today, Camphill's ecology is also shaped by environmentalism, the culture of short-term volunteerism among people in their teens and twenties, the governments and professional associations that regulate social care, the politics of austerity, and disability rights activism.

The disability rights movement is an especially important environmental factor because it highlights a core existential question for intentional communities of all types: does the renewal of society ever require a group of people to remove themselves from mainstream social institutions? If so, when and under what conditions should they reintegrate themselves? And, if the individuals in the group differ in their identities, abilities, and access to societal resources, who gets to decide what degree of integration is appropriate? Currently, disability rights activists have engendered a consensus, shared by most policymakers, that "institutions" that segregate persons with disabilities from the larger society are inherently dehumanizing. The activists (but not the policymakers) also insist that "disability" inheres not in individuals but in the "disabling" practices that are perpetuated by society. Yet there is no shared vision of what a nondisabling society would look like. Current governmental policies assume that a nondisabling society would be almost exactly like the current society, except that persons with disabilities would receive whatever assistance they needed to live in the same neighborhoods and work at the same jobs as people not deemed disabled. Such policies constitute a profound betrayal of the activists who first called for their enactment.

Traditional Camphillers, by contrast, assume that a nondisabling society would separate work from income, so that every person would be assured that their basic needs are met and empowered to perform work that is genuinely useful to their neighbors. They assume that a nondisabling society would be more rhythmical than the contemporary mainstream. People would be anchored to the cycles of growth and decay through work with plants and animals, participation in daily rituals such as the lighting of a candle at each meal, and the celebration of seasonal festivals. Finally, Camphillers also assume that a nondisabling society needs 
to do more than merely provide safe residences and meaningful work to people deemed disabled. It must also help people who have not been deemed disabled to encounter our own limitations and need for support, and thus learn to live in ways that are less disabling.

The difference in vision is so vast that many policymakers and activists perceive Camphill places as remnants of the discredited, institutional past. They are not wholly wrong to do so. In many ways Camphill has been too slow to absorb the best insights of the disability rights movement, and insufficiently creative in empowering persons deemed disabled to exercise democratic control of their residences and workplaces. But the perception of Camphill places as "disability-specific" communities that isolate people from the larger society misses the paradox at the heart of Camphill: though it may be "disability-specific" in relation to other intentional communities, it is just the opposite in relation to other models of social care.

Camphill's special contribution to communalism stems from the fact that inclusion of people with disabilities counters utopian illusions. Because the Camphillers with special needs come seeking the ordinary goods of societymeaningful work, deep relationships, physical safety-they balance those communalists who are so deeply dissatisfied with ordinary society that they are willing to sacrifice those ordinary goods in order to achieve an alternative. Camphill's contribution to disability rights, on the other hand, can be achieved only to the extent that it realizes its aspiration not to be a "disability-specific" community, but a place where all people contribute to a shared mission regardless of disability status. Disability rights activists have argued, quite rightly, that the logic of institutionalization and its dehumanizing effects are present whenever people with disabilities interact only or primarily with people whose role is to care for them. As one self-advocate put it, living in community means "integrat[ing] with people who do not have disabilities, and this does not mean staff." ${ }^{24}$ It does not matter whether the physical setting is large or small, and ultimately it does not matter whether the caregivers are paid or not. To the extent that one person is primarily a caregiver, the other person is reduced to a care-receiver rather than a complex human being. But not all nondisabled Camphillers are "primarily caregivers." Some see themselves primarily as farmers, bakers, artists, or lovers of community. All of these roles are also open to Camphillers with disabilities. By enabling everyone to build relationships based on shared devotion to diverse tasks, and by equipping everyone to give and receive care in roughly equal measure, Camphill creates a nondisabling society in which the old labels melt away. To the extent that Camphill fails in this, fostering one-dimensional relationships of caregiving and carereceiving, it replicates institutional patterns and merits the criticisms it has sometimes received from activists.

Many Camphillers would say that anthroposophical spirituality is another safeguard against disability-specificity and institutionalization. The heart of anthroposophy, they would say, is its vision of human dignity. Rudolf Steiner 
taught that each person is body, soul, and spirit. Each person has an individual soul, fully equal to all other souls, that holds spirit and body together. Each person has an essential connection to divine spirit that transcends the limitations of their present incarnation. Each person has chosen their current incarnation for the sake of important spiritual tasks. Rudolf Steiner applied this spiritual understanding to disability in part through his early experience working with Otto Specht, who had been deemed disabled because of his hydrocephaly and who was ultimately able to pursue a career as a medical doctor. Karl König cherished Steiner's view of the human as a confirmation of what he had learned through his medical training in embryology, and what he had experienced so powerfully when he first encountered children with special needs at an Advent celebration. Tilla König, for her part, experienced anthroposophy as the fulfillment of the long heritage of work with people with disabilities that characterized her childhood religion of Moravianism. Camphill's other founders, both those with and without disabilities, came to cherish anthroposophical spirituality because it created a space where they could meet one another simply on the basis of their shared humanity. Camphill's spirituality also provides a point of contact and fruitful difference with L'Arche. L'Arche has inspired much of the disability studies scholarship conducted by theologians, though it is scarcely better known than Camphill among other disability studies scholars. Like Camphill, L'Arche sees intentional community as a place where people can encounter one another's shared humanity, yet where Camphill accents our shared dignity, L'Arche stresses shared vulnerability and weakness. People in both movements would do well to explore this distinction. ${ }^{25}$

Camphill's deep grounding in a spiritual tradition is a quality it shares with most other enduring communal movements. A shared spirituality can help a young community survive by giving it a strong center and a clear boundary. But in subsequent generations, a healthy community's spirituality must become a bridge rather than a boundary. This is what happened for Christian and Buddhist monasticism, and it happens when Camphill seeks to learn from the insights of anthroposophists beyond Camphill, even when those insights suggest the need to disrupt some of the old, Camphill-specific forms. It also happens when Camphill's emphasis on spirituality provides an anchoring connection for people whose personal spiritual path is something other than anthroposophy. Like everything else in Camphill, this is a work in progress.

Whatever the future may hold, Camphill's endurance is cause for both admiration and careful study. Why has Camphill managed to survive thus far? One of the most caustic critics of nineteenth-century utopianism provides a helpful clue. After attending a gathering of Fourierists with several friends, Ralph Waldo Emerson mused "that Fourier had skipped no fact but one, namely life. ... The faculty of life spawns and scorns system and system-makers ... [and] makes or supplants a thousand phalanxes and New-Harmonies with each pulsation." ${ }^{26}$ Camphill, I contend, has survived because it has not skipped the fact of life. Born 
amid the hard facts of war, fascism, and prejudice against persons with disabilities, it has grappled with new facts in each generation. Some of the facts that confront it today are challenging indeed, and its future is not foreordained. But in all the messy complexity of its life today, Camphill has much to teach us about the future of community. 


\section{Camphill Generations}

All Camphillers would agree that theirs is a multiple-generation movement. But there is no shared understanding of where one Camphill generation ends and the next begins. The concept of a "generation" is inherently fuzzy. Since some people have children at age fifteen and others at age forty-five, three generations might pass in one family during another family's single generation. Some groups of people, born at roughly the same time, attain a powerful sense of shared identitymost notably the baby boomers (born between 1946 and 1964) and the millennials (born between 1980 and 1996). There are also events in Camphill's history that bonded specific generational cohorts together.

At least four generations have left powerful imprints on Camphill. I use the term founding generation to include the circle of friends who fled from Vienna to Scotland in 1938 and undertook the shared project of creating a school for children with special needs. These founders were born between 1902 and 1916; all but the Königs were tightly grouped between 1910 and 1916. The second generation, which I refer to as "those who came," includes children who enrolled in the early Camphill schools and coworkers, some only slightly younger than the founders, who joined the fledgling enterprise in the 1940s and 1950s. Baby boomers constitute a third Camphill generation of students, villagers, and coworkers. A few arrived in the late 1960 s, many more in the 1970s, and others as late as the 1990 os or beyond. Because this was the period of most rapid growth, baby boomers became the most significant generation in Camphill's history-a position they still hold today. Because Camphill has been relatively unsuccessful at gaining the long-term commitment of persons born in the 1960 s and 1970s, the fourth truly impactful generation has been the millennials. It remains to be seen what their impact will be: though many Camphill communities have achieved a successful transition from the leadership of baby boomers to that of millennials, others have not.

Between each pair of generations, there is a two-stage transition. The first stage involves the arrival of a new cohort of Camphillers; the movement's challenge at 
this moment is simply to make the newcomers sufficiently welcome that some of them will stay. A more challenging change occurs two decades later and involves the transfer of leadership to the new generation. Thus, Camphill's first generational transition began immediately after its founding and culminated in the 1960s, when founder Karl König transferred leadership of the movement to his younger cofounders and to the Camphillers who had arrived during the 1940s and 1950s. The second transition began in the 1960 s and reached fruition in the 198 os and 1990s, as König's successors made room for members of the Baby Boom generation who had streamed into the movement in the 1960 s and 1970s. The third transition is now in its final stages, as baby boomers seek to foster the leadership of a more diverse, millennial generation of Camphillers.

Each generational transition is characterized by a distinct task. The first transition, as scholars of other communal movements have observed, centers on questions of authority: can anyone other than the founder truly lead the community? Charismatic authority gradually gives way to bureaucratic leadership and to routinized structures. At the same time, community members with significant charismatic gifts are sometimes eager to step into the shoes of the founder. The community must discern the degree to which it can hold those charismatic gifts, and in some cases it must negotiate conflicts between rival inheritors of the founder's charisma.

The second generational transition has to do with trust. Can leaders who were mentored by the founders entrust the community's sacred flame to a generation that did not know the founders directly? It can be hard to practice such trust when, as is often the case, the life experiences of the new generation are different from those of their elders. They may not have experienced the intense challenge of building a community from the ground up, or in the face of societal hostility. The transition is easier if the community is growing rapidly, providing the rising generation with multiple opportunities to express its own leadership, and if communal structures provide opportunities for members of the two generations to build close interpersonal relationships.

The third generational transition, by contrast, demands confidence. Because the older generation did not know the founders directly, they may doubt their own authority to pass on the torch. If they have already made significant changes, they may worry that they have betrayed the founders. As with the second transition, the process is easier if rapid growth provides the new generation with leadership opportunities and if the two generations are able to work closely together. By this point in a community's history, however, growth is likely to have plateaued, while the proliferation of bureaucratic structures may limit opportunities for the two generations to interact.

\section{THE FOUNDERS}

Camphill had both an individual and a collective founder. Karl König was born in 1902 to a Jewish family in Vienna. As a medical student, he encountered the 
spiritual teachings of Rudolf Steiner-whom he never met personally-and committed himself to a career as an anthroposophical doctor, that is, someone who combines conventional medicine with healing practices taught by Steiner. König's cofounders included his wife, Tilla (Maasberg) König, and the members of two overlapping anthroposophical youth groups that formed in Vienna in 1929 and 1936. Many were ethnically Jewish, and a few shared König's commitment to the medical profession. Feeling a sense of common destiny, they explored ways to deepen their relationships with one another and searched for shared work. That search intensified when the Nazi annexation of Austria forced them into exile in Scotland. They created the original Camphill school for children with special needs on an estate called Camphill, just west of Aberdeen. ${ }^{1}$

Before that happened, the Königs were shaped by other colleagues who founded schools and communities devoted to what Rudolf Steiner called "curative education." In his own young adulthood, Steiner tutored a young man suffering from hydrocephaly, at that time believed to be a debilitating developmental disorder. Steiner helped this young man develop his talents to a remarkable extent, so that ultimately he pursued a career as a medical doctor. Steiner continued to contemplate this experience after embracing his career as a spiritual teacher. One of his practices was to offer lecture courses that applied "spiritual science" to specific professions. In 1920, he offered his first lecture series for medical doctors, collaborating with a doctor and student of anthroposophy named Ita Wegman. In the same year, Wegman established a clinic in the Swiss town of Arlesheim, just north of the Anthroposophical Society's headquarters in Dornach. Wegman's clinic began treating children with learning difficulties in 1923. A year later, anthroposophists in Jena, Germany, opened a home for children with special needs called the Lauenstein. Many of them had previously worked at the Sophienhöhe, a long-established, nonanthroposophical facility for children with disabilities. The Steiner-inspired Waldorf school in Stuttgart also established a special education class around this time. ${ }^{2}$

The Jena group asked Rudolf Steiner to give a course on the work they had undertaken. Curative education, he explained in this lecture series, is a way of "applying esoteric knowledge in practical life." Good curative teachers are those who "develop greater and greater interest in the mystery of the human organization." In other words, curative teachers could not hope to help children develop their whole selves-body, soul, and spirit-unless they too were on a path of spiritual development, and unless they were motivated by a deep "love" for "the soul-and-spirit nature that descends from the spiritual world" in each child. ${ }^{3}$ Steiner suggested that educators can participate in the ongoing spiritual evolution of humanity. Thus far, he explained, humanity has evolved a fourfold nature: each person has a physical body (also found in animals, plants, and minerals), an etheric or life body (found in animals and plants but not minerals), an astral or will body (also found in animals only), and an integrating ego (unique to humanity). The next stage of evolution will be the development of a "Spirit-Self." Other spiritual beings have already attained 
this level, and these beings help guide children's growth. Educators can thus cooperate with such spiritual beings as the "Genius of Language."4 Given this spiritual foundation, anthroposophical curative education focuses less on weaknesses and symptoms, and more on reverence for the spiritual potential of each child. To foster such reverence, Steiner suggested such practices as meditating each morning on the phrase "In me is God" and each evening on "I am in God." $\mathrm{He}$ also explored case studies drawn from the Lauenstein community.

In the wake of Steiner's curative education course, Ita Wegman organized one part of her clinic, known as the Sonnenhof, as a curative home for children with special needs. In November 1927, shortly after Steiner's death, Wegman offered her own course in curative education at the Sonnenhof, and encouraged the young anthroposophists who attended from around the world to create local communities modeled on the Sonnenhof. Thus, the Michaelgarden in Järna, Sweden, was established in 1932, anchoring a web of anthroposophical initiatives in that coastal city. ${ }^{6}$ In 1930, Wegman's student Sesselja Sigmundsdottir began Sólheimar (now Sólheimar Ecovillage) in her native Iceland. (Her collaborator and husband, Rudolf Noah, would later meet the founders of Camphill on the Isle of Man, where they were interned together as foreign nationals at the beginning of World War II.) ${ }^{7}$ Also in 1930, Wegman sent her student Fried Geuter to begin the work of curative education in England, and Bernard Lievegoed began work in The Hague, Netherlands. Just as Sesselja had translated "Sonnenhof" into Icelandic in order to name her community, so the Dutch school was called Zonnehuis and Geuter opted for "Sunfield" as the name of his school. ${ }^{8}$ Thus, the Camphillers were not the first to bring the work of anthroposophical curative education to the British Isles.

Both Karl König and Tilla Maasberg participated in Wegman's curative education course. König had begun reading Steiner's works in 1921, when he was a medical student and budding embryologist; he joined the Anthroposophical Society in 1925. Soon after he received his doctorate in 1927, König met Ita Wegman when she visited Vienna for the funeral of Rudolf Steiner's sister. Almost immediately she invited him to join her clinic's staff. Since he had already turned down a postdoctoral position because he had been asked to keep his anthroposophical commitments "private," he accepted the offer. During his first Advent in Arlesheim, he had a life-changing experience. He attended the "Advent garden" festival, in which each child followed a spiral path in order to light a small candle from a larger one burning atop a mound of green moss. "And suddenly I knew," he recalled later: "This is my future task! To awaken in each one of these children their own spirit light which would lead them to their humanity."

Tilla Maasberg, from Silesia, was a member of the Moravian Church who had recently become interested in anthroposophy. She applied what she was learning at a curative home she and her sister had already opened in their family's holiday house. A year later they were invited to expand this work at a new curative center directed by Albert Strohschein, one of the founders of the Lauenstein. This 
center was on the massive Pilgramshain estate owned by the von Jeetze family. The von Jeetzes found it easy to embrace anthroposophical curative education: they had been farming biodynamically since 1927 , and one family member suffered from a profound learning impairment. Members of the family remain connected to Camphill to this day. In 1929, Karl and Tilla were married, soon after Karl accepted the position of physician to the Pilgramshain community. ${ }^{10}$

Among the daughters of the Sonnenhof, Pilgramshain had an especially strong communal ethos. This was a legacy of the Maasberg sisters' Moravian heritage. The Moravian Brethren originated when the radical Pietist Count Nicholas von Zinzendorf (1700-1760) welcomed a group of Czech religious refugees to the village of Herrnhut on one of his estates. (Herrnhut is in the southeast corner of Saxony, just a few miles from Czech territory, and about one hundred miles west of Pilgramshain.) These refugees were part of the Unitas Fratrum, a remnant of the reforming movement founded by Jan Hus (1369-1415). Over centuries of persecution, the Unitas Fratrum had developed a semicommunal culture. Both they and Zinzendorf were committed to maintaining schools and homes for the poor. Hans von Jeetze, who suffered from hemiplegia, lived in a Moravian home in Herrnhut, and similar work was conducted by Moravians in Jena (site of the Lauenstein) as early as 1730. Inspired by all of this, Karl König identified the Unitas Fratrum teacher Amos Comenius and Zinzendorf as two of three guiding "stars" for Camphill. (The third was Scottish utopian Robert Owen.)"

Nazi hostility to Jews and to persons with disabilities, along with Karl's expanding medical practice, eventually pushed the König family to return to Karl's home in Vienna. There he connected with an existing anthroposophical youth group and organized his own. After two intense years, the Nazi "Anschluss" or annexation of Austria made them refugees once again. When it became clear that they would have to leave their beloved home, the members of the youth group vowed that they would find one another again in exile, and work together to rebuild the spirit of Vienna.

Karl König recalled this moment in an essay written twenty-one years later. During his first Christmas in Britain, he was "alone, a drop in the vast human sea of a city, a stranger, a foreigner. I knew that, together with me, tens of thousands of people shared the same fate. Men and women, old and young, children and adults, we were all in the same boat. It was the boat of loneliness; a ship without a destination, a life uprooted from the native soil and barely saved, like a plant which is given a handful of earth in a little pot of clay. How shall we survive?"12

In this evocation of the refugee experience, König drew on two biblical images: that of Noah's ark, seeking a place of refuge in a flooded landscape, and that of a precious seed that carries the promise of the future. He referred explicitly to the threat of Nazism: "I saw Austria overrun and conquered by men who betrayed the very essence of Europe.... Could we not take a morsel of the true European destiny and make it into a seed so that some of its real task might be preserved?"13 
In 1938 König was also an exile in a more intimate sense: he had recently been expelled from the Anthroposophical Society, along with his beloved mentor in the work of curative education, Ita Wegman. In the 1930s Wegman and her ally Elisabeth Vreede clashed with the other three members of the society's executive council, who accused Wegman of claiming too much of Steiner's spiritual authority for herself. The split echoed Steiner's break with the Theosophical Society, as well as earlier theosophical schisms. Wegman and Vreede were expelled along with several of their associates, including König and his friend Eugen Kolisko, who had given the very first anthroposophical lecture that König had attended. Among Wegman's allies were leaders in the British and Dutch branches of the society, including Walter Johannes Stein, a Jewish anthroposophist who had known König when they were boys in Vienna and then emigrated to Britain. The schism separated those branches from the rest of the society. ${ }^{14}$

The anthroposophical schism coincided with the rise of Nazism in Germany. Nazis began harassing Waldorf schools and curative institutions in 1933, forcing many anthroposophists into exile. The Camphillers were part of a wave of refugees who found their way to the Anthroposophical Society in Great Britain during the war years. Back in Europe, the remaining members of the executive council made significant concessions in order to keep anthroposophy alive in Germany. After the forced dissolution of the German branch of the society, they wrote a letter to Hitler affirming Rudolf Steiner's "pure Aryan heritage"; disavowing connections to Freemasonry, pacifism, and Judaism; and defending anthroposophy "as a valuable and active representative of German intellectual life." Thereafter, some anthroposophists participated in the anti-Nazi resistance while others cultivated alliances with deputy Führer Rudolf Hess and agriculture secretary Richard Walther Darré. ${ }^{15}$ Observing these troubling events from exile, König retained gratitude for everything he had received from the Anthroposophical Society, blaming its "breakdown" on "intellectual arrogance, a lack of faith, and human politics," as well as the fact that "the Christ impulse has not been able to permeate society." He dreamed of creating new social forms to replace what had been lost. ${ }^{16}$

The refugee experience helped knit the founders into a cohesive group with sufficient strength of will to build something new. On the one hand, they were aware and appreciative of the good will of their British hosts. "Britain at that time was the humane one of the European countries," recalled cofounder Anke Weihs. Camphill would never have begun had not British people "extended invitations and stood as guarantors for hundreds of Austrians and Germans whom they had never met." Theodore and Emily Haughton, friends of Ita Wegman who were active in the Anthroposophical Society in Great Britain, guaranteed the founders and provided them with their first home, Kirkton House, in northern Scotland. Anke Weihs, Alix Roth, and Tilla König set up housekeeping there in March 1939. ${ }^{17}$ When Karl König dedicated Kirkton House a few months later, he honored the hospitality of the British people, insisting, "We should promise one another not 
to create an island of central Europe here but to try as well as we can to act for the good of this land." ${ }^{18}$

Still, the warmth of friends could not fully overcome the coldness of making a home in a new country, with an unfamiliar language, as the violence they had fled threatened to spread across Europe. What is more, the founders did not yet know one another all that well. "No one should think that we were a closely-knit, rational group of people choosing the way we wanted to go," stressed Weihs. "Rathersome kind of spiritual suction drew us up and buffeted us about, shredding our little bits of accustomed ways of life, leading us time and again into our own darknesses within the gathering darkness in the world outside." Most had no previous experience working with children, let alone children with disabilities. Accustomed to "comfortable Viennese homes," they struggled to cook "on a rickety paraffin stove which maliciously poured out clouds of black smoke every morning." Those clouds of smoke were mirrored in Karl König's temper, which could erupt like a volcano when he returned after a week away, while he was pursuing a British medical credential at Saint Andrew's, to berate his friends for falling short of his "intense sense of order, cleanliness and beauty." Yet the struggles were punctuated with moments of pure magic, as when König interrupted Anke's dusting, pointed west to the peak of Bennachie, and told her, "that is where Noah's Ark came down to rest, and now when the floods of terror and warfare are once again covering the face of the earth, we too must build an ark to help as many souls as we can."19

Noah's ark soon shifted from crowded Kirkton House to the more capacious Camphill Estate west of Aberdeen. Relations with the Haughtons had grown tense because "they were so very British and we were so very continental." Now the Camphillers' leading patron was publishing heir W.F. Macmillan. Before the group could move, they were overtaken by world events. In the wake of the Battle of Dunkirk, all the Austrian-born men in the movement were relocated to British internment camps, and some of the British children were withdrawn from their care. Reduced to six women-Tilla König, Alix Roth, Marie Korach, Trude Amann, Lisl Schauder, and Anke Weihs - as well as a few children, the group could have stayed on at Kirkton. But after a challenging deliberation, they "unite[d] the[ir] separate hearts and minds into one strength and one deed," and made the move. ${ }^{20}$ The men trickled back the following winter, bringing about what Anke Weihs called "a stormy wedding feast between the male and female components of our community." ${ }^{21}$

Camphill's founding mission focused on children with special needs. Village communities for adults would not emerge for more than a decade, though Karl König first proposed such a community in 1938. Camphill was organized first as a residential community and then a boarding school in which everyone lived in the same houses, sharing meals, festival celebrations, and religious rituals. From the beginning, the children of Tilla and Karl König were part of the cohesive community, and the number of "staff kids" expanded as other coworkers 
formed families. Camphillers saw the presence of families as a strength, not an inconvenience, since their goal was to provide the children with an experience of authentic home life that, in the 1940s, was unavailable to many young people with special needs. Of course, the children could have enjoyed home life with their own families had their parents made different choices: the practice of sending children with special needs off to institutions had itself arisen only in the nineteenth century. Camphill emerged at a turning point in disability history-a time when some Western parents, especially those with economic privilege, were dissatisfied with the older institutions but not yet confident that society would help them meet their children's developmental needs at home.

In 1948 Camphill became a full-fledged school, offering a single Waldorf curriculum to the children with special needs alongside children of coworkers and of anthroposophical families in Aberdeen. Loans from W.F. Macmillan enabled the purchase of two additional estates, Murtle and Newton Dee, downstream on the River Dee. By 1949, Camphill School was educating 180 children and offering a seminar for newly arrived coworkers. Because Karl König's own medical practice frequently took him to consultations in England, word of Camphill School's success spread, and the movement began sponsoring satellite schools in 1948. The first was Thornbury House near Bristol, a residential hostel for St. Christopher's School, a center of curative education that König served as medical consultant. Then the Gleed family, whose grandson Charlie was a student at Camphill Aberdeen, offered the movement the use of their home in Ringwood, Hampshire. The possibility of creating a new school was put to the "youth group" of recently arrived coworkers, who were charged with identifying which individuals could play the pioneering role. Ursel Sachs and Averil Buchanan were chosen, and they escorted "seven extremely delicate children" on "a challenging and memorable" train ride to the south. Ursel, after her marriage to Carlo Pietzner, went on to cofound additional Camphills in Northern Ireland and the United States. The Bristol and Ringwood projects united as the "Sheiling Schools," taking their name from the Gleeds' home. ${ }^{22}$

Early on, Camphill's founders understood themselves as a "community," united by their commitment to manifest the spirit of anthroposophy through practical work. They gathered regularly to reflect on the art of living together, and to support one another in the practice of anthroposophical spirituality. Gradually this "Camphill Community" became distinct from (though interrelated with) the Camphill School and the Camphill Movement as a whole. For the sake of clarity, I will refer to it as the "inner community," though that phrase emerged only after new Camphillers, less rooted in anthroposophy, had arrived.

The inner community, which is not always mentioned in published accounts of Camphill's history because of its esoteric character, traces its roots to the two youth groups in Vienna. The refugee experience intensified the connections among members of these groups, and in the summer after the men returned from 
internment, the coworkers "met every evening until very late to discuss matters ranging from the broom-and-dustpan, arrangements of rooms, to our spiritual life, and began to know and to recognise one another." These are the words of Anke Weihs, who served as the community's keeper of memories. At Whitsun, König shared a dream he had experienced the previous August: Count Zinzendorf had appeared to him as a teacher "and proposed that human beings should gather together every Saturday evening to hold a meal and read the Bible in common, trying to understand the text by all that has been given through Rudolf Steiner in Spiritual Science." "Our reactions," wrote Weihs, "were partly dull, partly stunned and partly negative." As relative newcomers to both anthroposophy and Christianity, the other founders had little context for making sense of König's testimony. "Endless discussions ensued," in which König "could experience that hardly anybody would actually like to have it." Eventually, on the first anniversary of König's dream, just ten coworkers began putting it into practice. ${ }^{23}$

The resulting "Bible Evening" became a defining ritual for the inner community until it was opened up to other Camphillers in 1949. In February 1942 König established a method for formally admitting inner community members, but resisted requests that he draw up a quasi-monastic rule for the emerging "order." Though he did not deny that the inner community was like a religious order, he insisted that Camphillers place priority on the openness needed for social therapeutic work. He also made a special arrangement with leaders of the Christian Community, according to which the Camphill Community would be treated as a single, collective member of the Christian Community. All of this divided the founders. For Hans Schauder, the Bible Evening was an opportunity for König to separate the "sheep" who agreed with his interpretations from the "goats" who did not. ${ }^{24}$ Schauder, along with his wife Lisl Schauder and their friend Willi Amann, argued that the Bible Evening and other Camphill practices were infringing on their freedom. They left Camphill and form a new community called Garvald. ${ }^{25}$ Karl König responded by withdrawing from the inner community and asking that it be refounded, an action that mirrored Rudolf Steiner's refounding of the Anthroposophical Society in 1923. Finally, in 1945, König produced a defining document for the inner community known as the First Memorandum. This still serves as an inspiring statement of Camphill's ideals of lifesharing and incomesharing:

All who work in the Camphill Rudolf Steiner Schools in such a way that they do not claim payment in the usual sense, but:

Who do their work out of love for the children, the sick, the suffering, out of love for the soil, the gardens and fields, the woods and everything which is in the realm of the Community-

Who wish to do the work of their hands out of devotion to the Christ-Being who has reappeared in the ether sphere of the earth-

All who are thus willing to act for the true progress of mankind and who are consequently prepared to sacrifice their self-willing to the Spirit-willing; 
Who will fashion their lives according to the striving towards the Spirit of our age as it has been revealed through Rudolf Steiner, and as it is manifest in the sacraments of the Christian Community, as well as in the Cosmic Communion of the single human soul that wrestles for its development;

all those who are willing to participate in this striving may call themselves members of the Camphill Community. ${ }^{26}$

The First Memorandum also outlined a formal membership process and described the inner community's shared activities. It was released simultaneously with the creation of "The Camphill-Rudolf Steiner-Schools Ltd.," as the formal charity responsible for running the school, so part of its work was to demarcate the inner spiritual work of the community from Camphill's outer, educational task. A second memorandum, in 1948, similarly relinquished responsibility for Camphill homes, farms, and workshops. Finally, in 1949 König shared an "image" he had received, in which "the fruit of the Bible-Evening has ripened to such an extent that it starts to burst and the seeds are falling out." The locus of the Bible Evening then shifted from the common gatherings of the inner community to the individual Camphill houses, where all residents were free to participate. ${ }^{27}$ This decision was confirmed in a third memorandum. These decisions were intended to ensure that all consequential decisions about Camphill's outer activities would be conducted in a transparent and publicly accessible way. Another consequence was that the inner community remained somewhat hidden from Camphill's students, villagers, and newer coworkers, as well as from parents, neighbors, and social care authorities. Though the third memorandum stipulated all three memoranda would be "printed together and made available to those who work in places established through the initiative of the Community," this was not done consistently. ${ }^{28}$

The esoteric character of the inner community means that outsiders like myself cannot observe it as directly as the other forms of Camphill life. Yet I can observe at least two ways it has been significant for the Camphill story. On the one hand, it played a decisive role in anchoring the commitment of most long-term coworkers of the first, second, and third generations. Usually, the decision to start a new Camphill place emerged from the spiritual striving of the inner community. On the other hand, the inner community's primary gesture has always been to relinquish direct control of the places it has inspired-in the words of long-term Camphiller David Adams, "it gives the Places to the world." The consequence of this relinquishment is that the inner community is no longer the primary body shaping the Camphill Movement's future. Many Camphill places have no inner community members in residence. Yet, as David has observed, inner community members continue to be inspired to "found new places where the impulse of Camphill can live," even if these do not always bear the name of Camphill. ${ }^{29}$

Though other members of the inner community did more than Karl König to shape the daily rhythms of Camphill life, his charisma dominated the movement. Other Camphillers called him father, and spontaneously trusted his guidance 
about their life choices-even if he asked them to establish a new community on a distant continent. His choices thus shaped the first generational transition. By guiding Camphill's expansion around the world, König allowed members of the founding circle to strengthen their leadership skills as founders of communities far from Scotland. In the 1950s, little more than a decade after Camphill's birth, the founders established schools that still endure today in Northern Ireland, Holland, Germany, and South Africa, as well as an unsuccessful school in Norway. Camphill's growth in Germany was particularly dramatic. Since one of Karl König's initial goals had been to restore the true spirit of Middle Europe, he was thrilled at the establishment of Brachenreuthe near the shores of Lake Constance in 1958. He came to regard Brachenreuthe as "the Camphill Movement's dearest child." Two other schools, Föhrenbühl and Bruckfelden, were established nearby. Also in the 1950s, anthroposophists began curative education schools in Finland and the United States that would soon be absorbed into the Camphill Movement. The geography of Camphill today mirrors that of Camphill during the König's lifetime. Two-thirds of Camphill places today are located in the eight countries that Camphill had reached by 1960 .

König made another significant choice after he experienced a serious illness in 1955 . He began handing his own leadership tasks to others. In 1957, he designated Thomas Weihs, who had been part of the second youth group in Vienna, as superintendent of the original Camphill school, and claimed a new role for himself as chairman of the Camphill Movement, a global coordinating body. Seven years later, he relinquished that role but did not appoint an individual successor. Instead, he created six distinct regions, each with its own chair. The people he designated as regional chairs were usually founders of the schools or villages that anchored Camphill work in their particular region. Many of them exercised a charismatic authority within their region that was similar to the authority König had held over the movement as a whole: they chastised and encouraged new coworkers, and directed seasoned Camphillers to establish additional places. Others were chosen to foster coordination among the regions and to nurture the development of the inner community. This distribution of responsibilities set a precedent for the further devolution of leadership. König sealed the transition by relocating from Aberdeen to Brachenreuthe, where he spent his final two years fostering Camphill's growth in the region where his life had begun.

\section{THOSE WHO CAME}

Karl König's retirement and death did not bring Camphill's first generation entirely to an end. Tilla König, like most members of the founding circle, lived on into the 1980s, and three of them-Peter Roth, Marie Korach, and Barbara Lipsker-lived even longer. Still, from the 196os through the 1980s the Camphill Movement was guided by the two clusters of Camphillers that I identify as the 
second generation: the students who began arriving in 1939 and often stayed on as adult villagers, and the young volunteers who came during and after World War II, especially those who participated in the Camphill seminar in curative education that was launched in Aberdeen in 1949. Both students and seminarists had experienced displacement and exile, usually beginning earlier in life than was the case for the founders, and they gave Camphill an inward-looking, self-reliant culture.

Early in the twentieth century, it was common for children with disabilities to be separated from their parents and placed in large and neglectful institutions. The initial Camphill school offered these children a safe home and an alternative sense of family. As these children grew up and graduated, it became clear that the larger society was still not ready to include them. Thus, the defining task of Camphill's second generation-albeit undertaken at the direction of the founders-became the creation of "villages" in which adults with and without disabilities would share life and work. The new villages accelerated Camphill's growth, preparing it to absorb the thousands of young people who would stream toward it in the third generation.

Just as the school at Camphill Estate set the pattern for other Camphill schools, Botton Village in North Yorkshire became a prototype for other villages. Like Camphill's work in Scotland, Botton Village's birth was intimately tied to the Macmillan family. The Macmillans had founded one of Britain's leading publishing houses in 1843, and among their descendants were both Prime Minister Harold Macmillan (who served from 1957 to 1963) and Alistair Macmillan, a much-loved student at Camphill School Aberdeen. In 1955 Alistair's mother persuaded the rest of the family that they no longer needed their six-hundred-acre vacation estate in North Yorkshire Moors national park. They invited the Camphillers to use it to create a permanent village home for Alistair and other Camphill students who were then reaching adulthood..$^{30}$ Botton's rural isolation set the tone for many subsequent villages, though few could match its sheer scale. Nestled in a valley between high moors, it is capacious enough to include several autonomous farms. In its heyday, it hosted a Waldorf school, a grocery store, a publishing house, a seed business, its own post office, and training courses in social therapy, eurythmy, biodynamics, and other anthroposophical initiatives. From many locations in the village, one can overlook a scenic panorama that is entirely within the boundaries of Camphill.

From the beginning, the Camphillers were clear that the "social therapy" practiced in the villages would be different from the "curative education" of the schools. "It is not appropriate," Karl König stressed in his first lecture on village life, "for us to look upon grown-up people with whom we live, work, and share our life and destiny in order to analyse and diagnose them.... If we fell into this trap of modern life ... we would become like their jailers and they would be like our prisoners." ${ }^{31}$ Reflecting on this some decades later, another Camphiller noted 
that while a curative educator may help a student "overcome her inheritance," a social therapist's "task is to help her to fulfil this destiny." ${ }^{2}$

König also hoped that Camphill would help revive the "village" as a distinct social form. When Botton Village opened in May 1956, he described village life as an antidote to "three great errors" of modern civilization. The first error, which he traced to the French Enlightenment, was the idea that humans had created God rather than the other way around. This error had led humans to "chain nature with the fetters of modern technical inventions," culminating in "the destructive powers of electrical and atomic energy." A second error was the notion of the survival of the fittest, which König saw as the source of twentieth century tyranny, even to the point that he affirmed, "Where Darwin started, Hitler and Stalin continued." Finally, König discerned a third error in the nineteenth-century invention of intelligence tests, which led to "the most ridiculous specialization and segregation" in schooling, as children were subjected to countless tests that determined what schools they would attend..$^{33}$ Though König lacked the terminology of the twenty-first-century disability rights movement, these errors constituted his diagnosis of the roots of a disabling society.

König argued that the three errors guided "most of the leading men" in "politics, science and industry" and even in the churches. But he also discerned a countervailing power, still "hidden and unknown," in "many single people who feel the oncoming disaster with pronounced certainty" and respond by seeking for "a new way of community living." "These single men are convinced that they should extend their family bonds over a greater number of people and live with them as with brothers and sisters." He identified communal movements and broader social impulses as indicative of the new quest for community: the Iona and Taena communities in Great Britain, the Bruderhof, the use of "back to the land" as a catchword, the work of the Soil Association in promoting organic agriculture, the writings of Aldous Huxley, the notion of "human relations." ${ }^{34}$

Placing Camphill in this context, König emphasized that it was not enough to provide "an asylum, a retreat or a place of escape" from a world distorted by the three errors. The Camphill Village, he said, would be "not only a stop-gap for handicapped persons, but a vital experiment for future needs," insofar as it would teach people to overcome the errors. Village life would teach people of supposedly "normal" intelligence "to overcome their pride and arrogance" and relate to others on the basis of human-ness rather than intelligence. By discerning the "spirit-existence in our neighbour," residents of the village would overcome the Darwinian error. And by "renewing our enthusiasm for our every day work," they would live "in the radiance of the divine presence," much like the medieval builders of cathedrals. ${ }^{35}$ Camphill's communal ethos, in other words, was König's strategy for creating a nondisabling society that would gradually extend beyond Camphill's boundaries. 
This village vision challenged the first two generations to transcend their refugee roots. Despite its difference from the surrounding society, Camphill hoped to be a catalyst for change, in alliance with kindred impulses from beyond the anthroposophical subculture. The impulse to reach out was echoed in an editorial that appeared in the Camphill Movement's journal. The editor cited an unnamed public intellectual who had predicted a "social catastrophe" that would be followed by a "spiritual revival" inspiring middle-class British people to "repopulate the forsaken and barren glens and dales of the country, giving rise to a new culture based on new values." This editorial suggests that Camphill had entered a paradoxical moment: they had the chance to break out of their inward-looking, refugee mentality, but only by partnering with other social impulses that had something of a refugee spirit and an antipathy to the modern world. ${ }^{36}$

Because many of Botton's first villagers were graduates of Camphill School, they brought with them a deep grounding in Camphill life and were able to exercise significant leadership in shaping it. "The village to my mind is as different a creature as any other child," observed one coworker who encountered Botton when it was six months old and was inspired by the people she met there. "These odd people had just arrived. They hadn't changed the architecture in any way.... But the idea, the idea of the village was correspondingly loud and clear. I heard the idea actually originally from two handicapped people. A person with Down syndrome and an epileptic, but I didn't know 'what' they were until afterwards. It seemed to carry answers to all my urgent questions." When she met Karl König, he reinforced her sense that the people with special needs were to be the ones shaping village life. "I can't tell you what you are doing here," he explained. "I can't tell you how to do it. All I can tell you is, do it together. These are not pupils anymore. You are not teachers anymore. Forget if you were pupils and teachers. You are grown-up people trying to make your living together, somehow, because none of you can make your living individually." ${ }^{37}$

It took about a decade for villages to supersede schools as the dominant form of Camphill life. In the years just after Botton's founding, the movement planted its first schools in South Africa, Finland, Germany, and the United States. It added villages in most of these locations early in the 196os. The school in Northern Ireland, Glencraig, evolved into a hybrid community comprising both a school and a village. Back home in Aberdeen, the Newton Dee estate was repurposed as an adult village managed by the same charity as Botton. That charity, the Camphill Village Trust, added new villages in England as the demand for residential spaces outpaced supply. Often, the parents of Camphill school graduates insisted that the movement establish new villages for their children. Camphill also planted villages in nations that had never been home to a Camphill school, as was the case in Norway in 1966 (with the founding of Vidaråsen) and the Republic of Ireland in 1972 (Duffcarrig). The same pattern persists today, as Camphill's work in Russia, India, and Vietnam has begun with villages, not schools. 
Villages today account for nearly half of all Camphill places and more than half of the total Camphill population. Many of those founded in the 1960s have evolved into complex, multifaceted social organisms in keeping with the pattern set at Botton. Camphill Lehenhof, the oldest village in Germany, is home to 270 people, half of them adults with special needs, and a place of daily work for about eighty more. Its three distinct neighborhoods encompass a dairy farm, a performance hall that doubles as a chapel, an industrial area, and a grocery store that mostly serves non-Camphillers. Lehenhof's daughter community, the Hermannsberg, is almost as large, with 114 people receiving special care and living alongside 100 residential coworkers as well as 100 nonresidential employees. Its location has a deep communal heritage, having served previously as a beguinage, a Franciscan convent, and a school led by the founder of Outward Bound and United World Colleges. Camphill Village USA in Copake, New York, is home to almost 240 people and includes a biodynamic seed business with a national customer base as well as a chapel, performance center, and lively café. No one knows for sure which Camphill village is the largest in the world today; one strong candidate is Perceval in Switzerland. Perceval's social organism, which has both residential and nonresidential components, includes 100 children and 80 adults with special support needs as well as 380 salaried coworkers.

From the beginning, Camphill villages had a palpable sense of shared endeavor. Everyone had a role to play in erecting homes and establishing farms. Since the residents with special needs were less likely to move from one village to another or leave the Camphill Movement altogether, over time they became some of the most experienced communitarians in the movement-the resident experts on the story and customs of each place. When filmmaker Jonathan Stedall visited Botton Village in 1967, for example, he observed that Alistair Macmillan still anchored the community he had helped found. In the mornings, Stedall heard Macmillan singing in a falsetto voice as he worked in the garden; in the afternoon he switched "to his other job, delivering the post to the seventeen households throughout the village and stopping for a gossip whenever possible." ${ }^{8}$

Other villagers who arrived in the 1940s and 1950s shaped the youthful communities where they lived. Susan Calvert arrived at Glencraig in 1957, when she was eighteen and Glencraig was just three years old. She was already somewhat familiar with Camphill life, having attended St. Christopher's School in Bristol and spent time at Botton Village. She quickly took on significant responsibilities, including work as an assistant in a children's dormitory. She also "acquired the skills of an accomplished weaver" and became a devoted participant in the services of the Christian Community. Over forty years at Glencraig, she saw many friends move on to the newer villages of Mourne Grange and Clanabogan, and was continually valued for the "great sense of joy in all that she undertook." 39

Camphill's expansion required an influx of new coworkers, and this was facilitated by a concurrent change in international policy. Beginning in 1949, the border 
between East and West Germany was briefly opened. People with connections to anthroposophy were among the hundreds of thousands of migrants who fled the increasingly rigid Soviet control of the eastern territory, often continuing out of Germany altogether. ${ }^{40}$ To absorb them into Camphill's ethos, König organized a seminar in curative education in 1949. Its first cohort of twenty-five participants were drawn almost entirely from Germany, with eleven having been born in what became East Germany and ten more in the West. Several had long-standing ties to anthroposophical work in Silesia and Stuttgart; at least two had direct ties to the Lauenstein and two more to Pilgramshain. One of the latter was Hartmut von Jeetze, a child of the family who had provided the Pilgramshain estate. He would go on to serve as the first farmer at both Newton Dee and Copake, as well as the cofounder (with his wife Gerda, also a member of the first seminar) of Camphill Village Minnesota.

The few non-German coworkers who arrived in those years could not help but be "very much impressed with the refugee element," as one told me. "Coming from a spoiled childhood in the north of Scotland where the war had not affected me physically much at all. .. . I was impressed with all these folks coming from Germany ... and working with our land and our handicapped people in what was for them a foreign language." ${ }^{41}$ Similarly, a young Scandinavian who arrived in the 1950 observed that the schools in those years were full of young Germans "who roll up their sleeves and set to work." ${ }^{22}$

For German refugees who were traumatized by their wartime experience, Karl König's charismatic self-confidence had a stabilizing and healing effect. The Scandinavian coworker told me the story of one of these "traumatized young people who came from the ruins of Germany." She was responsible for "a dormitory of very ill children," and when one of them smeared the walls with feces, she reached her limit. Desperately afraid she might kill the child, she ran out into the forest and "raged." But when she returned to tell König that she would have to leave, he calmly replied that he would "be behind you," making sure she would not harm anyone. "He pulled many of these people out of the dirt," explained my source, "and made them into efficient young men and women." And yet when the Scandinavian arrived, not so many years later and with a less traumatic background, König was "more a distant figure" with an authority that could be offputting. ${ }^{43}$

The same coworker shared a vivid picture of the intensity of Camphill life in the 1950s. "We had to work damn hard. You had been on your feet from six o'clock in the morning, you had a group, you had a class, and then finally in the evening you got the children into bed and then the evening activities started at nine o'clock... We had to belong to seminar to do a play. I lived first in Cairnlee which was a mile and a half away, then I lived in Camphill which was two miles." Play practice began after the evening seminar, "and at half past twelve in the night we had to walk back on the railway line to Camphill." What made it possible was the group dynamic that developed when each coworker was responsible for seven or eight 
children. "If you managed to hold that, they also educated each other." By contrast, the baby boomers who came later often refused to take on groups of more than five children, while at Camphill school today there is often one adult to every child. ${ }^{44}$

This intense experience prepared second-generation coworkers to found new Camphill places in the 1960 s and 1970s. Even after the seminar had been going for a decade, the movement was so shorthanded that participants moved rapidly into positions of great responsibility. One coworker who arrived in 1957 said that after two years of seminar she was immediately designated a housemother for eight children, which at that time was considered to be a "small unit." 45

The inner community had only recently been opened to people from beyond the founding circle, and it still carried an aura of esoteric mystery-and of the power to overcome challenges. In 1949 and 1950, Barbara Lipsker later told a coworker, the path to the inner community was quite quick, out of necessity. "After three months you had to join the inner community or you left, because it was so tough. And it happened quite often that, one morning, the person disappeared." ${ }^{4}$ Beginning in 1953, the inner community was subdivided into ten "sectors" in order to foster spiritual intimacy within a growing movement. Each sector studied distinctive texts and took on distinctive meditative practices, and new members found their way to a particular sector because of affinities with older members. ${ }^{47}$

"I realized there was more to [Camphill] than the eye saw," recalled one coworker who arrived in the 1950s. "I questioned," and gradually she learned about the inner community. "At that time it was so secret that often in the beginning, husband and wife didn't know from each other in which sector they were." ${ }^{8} \mathrm{Her}$ experience was echoed by a coworker who arrived around the same time. Early in his time at Camphill, the inner community had been temporarily dissolved, then reestablished on a more secretive basis. "It went underground. It wasn't talked about. You didn't speak-you could speak to your fellow sector members, but you didn't speak about it to others. And you had to search to find it. Whereas before it had been thrown at you." And so it was that, after some time in Camphill, he came into a meeting and says, "I suddenly experienced that behind each person there was something, which I am not part of." That made him aware of the inner community, but even so he did not resolve to join it until the death of Karl König in $1966 .{ }^{49}$ The inner community would continue to thrive, and to evolve, in the generation that followed.

\section{THE BOOMERS}

Karl König's death coincided with a vast expansion of Camphill. In 1966 there were thirteen schools and nine villages worldwide; within twenty years, an additional forty-eight Camphill places had been started. At one gathering of British Camphillers in 1975, "no less than sixteen possible new projects were on the agenda for discussion," and the same dynamism was present elsewhere..$^{50}$ 
A movement-wide census in 1976 reported 4,262 persons affiliated with Camphill, 20 percent more than had been counted just two years earlier. ${ }^{51}$ New Camphillers were attracted by the movement's youthful spirit, expansive energy, and (compared to the era's many brand-new communal movements) relative stability. Many of these newcomers stayed on and continue to anchor Camphill places today. Some have spent more than twice as many years in Camphill as Karl König did! By my reckoning, they are Camphill's third generation, and its most influential thus far.

The expansion of Camphill was driven, first and foremost, by the desire of adults with special needs (and their family members) for places to live that would honor their human dignity. During the 1960s, the large institutions that had once housed most people with intellectual disabilities shut down very quickly-more quickly than a culture of genuine inclusion could sprout up in the larger society. (Many would say such a culture has still not sprouted!) Camphill also had an internal dynamic that was expansionary. The earliest Camphill villages had been founded to accommodate graduates of Camphill schools who could not find equally affirming homes and workplaces in the larger society, and these schools kept producing new graduates after Botton, Newton Dee, Copake, and other early villages had filled to capacity. At the same time, of course, many graduates of Camphill schools did not go on to live in Camphill villages, and many adults with special needs came to the villages without previous Camphill experience.

The evolving aspirations of persons with special needs prompted Camphillers to create two new community types in the 1960 s and 1970s. These take many names; for convenience I will refer to them as "town communities" and "training colleges." The former deliberately eschew the rural isolation of Botton in favor of immersion within a small city or suburban neighborhood. Town communities are typically smaller than villages, often including just two or three households. These households may be dispersed within a residential neighborhood. The first town community, Heathfield Cottage, was established in Stourbridge, England, in 1968-69, and has since expanded into a cluster of households. This project was inspired by the desire of some Camphillers with special needs "to try themselves in ordinary society, away from the sheltered and settled life of a Camphill village community." At the same time, Camphill coworkers had noticed that when "so-called 'normal' people [are] faced with handicapped adults who were coping with life," they begin "to ask new, very worthwhile, questions-about themselves, society and mankind in the present day." They hoped that an urban community would "expose many ordinary citizens" to this transformative process, fostering a nondisabling culture in the larger society. They were keenly aware that their experiment would fail if it did not transform the neighborhood in which they planted themselves: "Community-care . . . would simply remain a newfangled facility for the handicapped and fail through social isolation if it were not recognized at the same time that this meant caring-for-community in a society which barely recognized neighbourliness." ${ }_{52}$ 
Another town community, known as the Croft, was founded in 1974 and grew out of the desire of villagers at Botton for more social engagement, as well as from the Camphill Movement's desire to respond to the calls for a more "integrated" approach to care for persons with special needs. The "urban environment," reported one founder, would "afford the possibility of open employment to those handicapped people who wanted to experience 'real life'; but it would also need land and its own workshops to enable a balanced life of community to evolve around and within it." ${ }^{53}$ Forty years later, one Croft resident told me that she much preferred the lively social scene of the town of Malton, where the Croft is located, over Botton's rural isolation.

Town communities typically are anchored by a coffeeshop, gift store, or bakery, businesses that provide daily opportunities for Camphillers to interact with their neighbors. The founding of the Croft brought Camphillers into conversation with a host of neighbors who had never taken an interest in the more remote Botton Village: the Lions, Rotary Club, and Probus Club helped prepare the house for occupancy, and a local Quaker group brought in working parties from a nearby home for young offenders. ${ }^{54}$ "Everyday," reported one founder, "there are at least two or three callers who want to help with this or that." ${ }_{55}$ Camphill Hudson, similarly, maintains two houses and a lively gift shop in the city of Hudson, New York, a rust belt community whose renewal has perhaps been accelerated by Camphill's energy. On the outskirts of Belfast, Camphill Holywood operates a thriving coffeeshop that is a favorite volunteer site for local teenagers, some of whom also participate in environmental education programs in the more traditional, agricultural Camphill communities nearby. "It is a genuine, real business," explained coworker Veronika van Duin, "and the town of Holywood would absolutely hate it if we disappeared." ${ }^{56}$

The Bridge Community in Ireland takes its name from the bridge that is at the center of the town of Kilcullen. It is home to a coffeeshop and to a farmand-nature trail that allows its neighbors to get their exercise while walking between the River Liffey and the community's houses, gardens, and livestock pens. Interpretive signs introduce visitors to Camphill values, ecological principles, and folk wisdom about plants and animals. What's more, the whole thing was built by a team of volunteers from Fidelity Investments, forging an ongoing tradition of cooperative volunteering between Camphill and its neighbors. "The inspiration" for the community, explained management coordinator Mischa Fekete, "was that it would be integrated into the wider community ... not just to integrate the people with special needs into the mainstream, which is a very dubious concept," but to help "people in society start to actually see what the true task of people with disabilities might be in society." Thus, a customer at the coffee shop, "meeting the people with special needs," would see that they "are respected, are fully a member, make their contribution." The Camphillers thus make a special effort to participate in the Tidy Towns group, the Kilcullen Community Action Group, and the local 
drama society. "You take your friends to meet your other friends and gradually the thresholds diminish." ${ }^{57}$

Three years after the creation of the first town community, Camphillers developed another new communal form. As with the town community, the first training college, the Mount, was established in England. Its mission is to provide a collegelike educational experience for people with learning difficulties between the ages of sixteen and twenty-five. Camphill training colleges (also referred to as "youth guidance" communities) have thrived because they fill a significant gap in the social care system of most Western nations, which have done a better job of guaranteeing appropriate public education to people with disabilities than of providing for their housing and employment as adults. While fewer parents of children with special needs are willing to send their young children off to Camphill boarding schools, many find value in residential programs designed to ease the transition to adult responsibilities. Camphill training colleges enroll graduates of Camphill schools and young adults who had previously lived with family, and they prepare their students for either Camphill village life or independent or supported employment in the larger society. The training colleges have allowed Camphillers to develop a new field of anthroposophical activity, usually referred to as "youth guidance," located in the space between the older fields of "curative education" and "social therapy."

As with town communities, many training colleges began as offshoots of older Camphill places. Camphill Soltane, in Pennsylvania, is located just a few miles from both a school (Beaver Run) and a village (Kimberton Hills). An additional training college, known as Beaver Farm, is currently a semi-autonomous unit of Beaver Run. Similarly, New York's training college, Camphill Triform, is part of a four-community cluster that also includes a village, a town community, and an elder community.

Cairnlee is a training college under the auspices of Camphill School Aberdeen; its emergence in this role reflected the impulse toward both town communities and training colleges. Around 1970, Camphill School decided to sell Cairnlee, a much smaller estate than either Camphill or Murtle, because it felt like a "small annex" to the other two and because it had "lost its seclusion on being engulfed by a very dense development of housing estates around it." But the new emphasis on integration in disability policy led the Camphillers to rethink their assumption that "every Camphill place must be at least a mile or so away from all other developments." ${ }^{8}$ A new phase of Cairnlee's history began in 1988, when a group of senior Camphill School students who were struggling to make the transition to adulthood moved there with a group of four seasoned coworkers. They developed a common life that was focused less on work than the adult villages, and was characterized by a "therapeutic approach which does not put any pressure on our students but leaves them free to develop at their own pace."59

Perhaps because many of their disabled residents spend only a few years of their life in Camphill, training colleges often have a "progressive" ethos of engagement 
with the larger society. In order to give their students genuine choices about their postcollege lifestyle, the training colleges partner with local businesses to provide workshop experiences that mirror mainstream employment. Soltane has partly evolved into a town community, as many former students have relocated to apartments in the nearby town of Phoenixville. The community sponsors multiple businesses in town, including two cafés and a store specializing in fabric arts. These enterprises provide Soltane students with individualized internships designed to help them develop skills for retail jobs. It maintains a community art center whose classes are patronized by non-Camphillers, both with and without disabilities. It aspires to be a seedbed for additional social enterprises, not all of them focused on disability. ${ }^{60}$

The geography of Camphill expansion between 1966 and 1984 was different than that of the previous quarter-century. By 1966 Camphill had expanded to ten countries, and that number grew to only fourteen in 1984. The vast majority of new Camphills were planted in countries where Camphill was already present, often close to existing Camphills. Increasingly, students at Camphill schools came from nearby towns and cities, and both they and their parents wished for them to remain close. The good news of Camphill also spread by word of mouth among families of people with disabilities, who often took the initiative to invite Camphill into new places. Whereas Camphill growth had once depended on the missionary zeal of anthroposophists and the human need of German-speaking refugees, it now depended on the enthusiasm of people with disabilities and their families.

By far the largest share of Camphillers whom I have interviewed have been lifesharing coworkers from the baby boom generation. They are a large cohort who share many experiences and perspectives. A few of them were born into families of coworkers; far more arrived in the late 1960s, the 1970s, and even the 1980s and 1990s. By the 1990s they held most formal leadership positions in the movement, and in many Camphill places they still do. In some ways, my reliance on their testimony and experiences - shaped in turn by my primary identity as a communal studies scholar-may have distorted my perspective on what Camphill truly is. Other observers, with different research questions, might give them less attention than I have. Yet no observer of Camphill could ignore them altogether. It is unlikely that any other cohesive cohort will ever hold a comparable amount of power in Camphill again-since, as I shall argue in the next section, in subsequent generations lifesharing coworkers have shrunk to a much smaller proportion of the total Camphill constituency.

The forces that brought baby boomer coworkers to Camphill in the years between 1966 and 1984 were utterly different from those shaping the biographies of previous Camphillers. The refugees of the 1940s had been traumatized by war and were seeking a place of safety; the boomers had been raised in middle-class prosperity and brought idealistic, even utopian dreams. "We were different from previous generations," one boomer told me. "They had gone through the Second World War and had really suffered ... and then after the war they were looking for 
a new life. A lot of them were inspired directly by hearing Karl König speak. [Their goal was to] rebuild Europe and Britain after the tragedy of the Second World War. Our generation was more, we are the hippies and we are going to kind of idealistically help everybody." ${ }^{1}$

Those who arrived in the late 1960 s encountered stable, settled communities dominated by a Germanic and anthroposophical culture that was quite different from 1960 south culture, but equally different from the middle-class culture of the new arrivals' parents. Some of these newcomers had already encountered Rudolf Steiner's ideas in other contexts and were eager to see these lived out in a practical way. Sherry Wildfeuer, for example, visited Beaver Run in 1966 after discovering anthroposophy through a classmate at Bard College. Reading Steiner's books gave her a new zest for learning, but not one her professors could easily accept: "Suddenly I was fascinated by everything I was learning. Before that I had been an A student and just giving . . back ... what they wanted. Now I wanted to know what is true. . . . That's when I went to Camphill, because I wanted to know, what do people do who think like this." When she arrived, Sherry and her classmate were the only young people at Beaver Run. Since there "was no format for being a shortterm coworker," she was accepted into the shared work of the community and had the opportunity to meet Thomas Weihs, Barbara Lipsker, Carlo Pietzner, and other Camphill founders. By the time she left a year and a half later-to pursue training in biodynamic agriculture - "there were way more" young people at Beaver Run. ${ }^{62}$

By the 1970s, the experience of arriving in Camphill had changed dramatically. One Norwegian coworker first learned of Camphill as a schoolgirl, selling candles to benefit Vidaråsen. When she came of age, she and a friend tried to join Vidaråsen because "at that time the only thing to do was to find an intentional community somewhere." It was too full to accept new volunteers, so she did the seminar at Camphill Scotland, then returned in 1974. Vidaråsen was growing so fast that they constructed a new building every year. Apart from the founder and two other women, everyone was in their twenties and "that meant of course that people in their twenties took on a lot of responsibility, often learning by doing. Running houses and having services and everything. And having children." ${ }_{3}$

As the number of young people living in Camphill increased, it was more and more possible for people to arrive merely because they had friends in Camphill. One coworker told me that she was "just visiting a friend who was at Glencraig. I didn't know anything about anthroposophy or the background or learning disability. The people there said, 'We've got a training course. Would you like to stay and try it?' I thought, well, this is something a bit unusual. Yes, I could try it, then I'll leave. I was going to go to England and get a job as a teacher. Well, obviously, it was my karma, my destiny to do that." ${ }^{4}$ Another told a similar story: "I heard about Camphill from a friend at university, and I went to the Grange Camphill community in Gloucestershire in January 1975, in an open-ended kind of way. . . . I was attracted to it because it sounded like a commune, countryside and odd people.... 
I was not committed beyond a few months" - and yet I met him at a Camphill just a few miles from the Grange almost forty years later. ${ }^{65}$

Many of the new arrivals came with a mix of political and spiritual experiences that had stoked their idealism but also left them hungry for an alternative to hippie and New Left culture. Sherry Wildfeuer had been president of her high school's human rights club, but she was "given so much social consciousness" that by the time she was sixteen "I felt just helpless." When she came to Camphill, her encounter with anthroposophy helped her see that "I could take hold of myself at least and make changes. I didn't feel so hopeless." ${ }^{\prime 6}$ Russ Pooler, of Newton Dee, told me that he and his wife had arrived in 1972 after several years in the San Francisco hippie scene. "I was into poetry. . . . My wife was an artist, a painter. . . . She was into Buddhism and we lived in a Buddhist commune for a while. We also lived in a big house with lots of people in San Francisco. ... We were both searching around for things." They were also troubled by the aimlessness of hippie communes that were "a lot of fun" but "going nowhere," by the fuzziness of Eastern mysticism, and by the polarization of radical politics. "I was longhaired, beard and all that and living that life, but I wasn't completely convinced. I was much more artistically inclined." At Camphill, he found a political middle ground and the chance to stretch himself artistically: "The whole way they dealt with money and with art, everything was very artistic. You were free to do what you liked. I was able to run a toy shop, which I'd never done. ... I'd written poems and stories and things. . . But I'd never done anything with my hands, really. It was really nice to start working like that." He also liked the fact that "it was possible to work and not have to pay your taxes and worry about all the money and stuff and you could live and help people and learn about yourself and you could take your Steiner or not, depending. I took it very seriously." ${ }^{\prime 7}$ At Cascadia in Vancouver, Patricia Smith explained that her interest in alternative schools led her to investigate "Summerhill and Findhorn and Montessori," while Bruno Bettelheim's Children of the Dream inspired her to spend eight months on a kibbutz. "I then went to Switzerland to visit some people I had known in the kibbutz. And in hitchhiking someone picked me up who was involved with the Waldorf movement. So I found out about the Waldorf movement and became involved with that and through that I found out about Camphill and went and visited Camphill. And I guess that turned the course of my life." ${ }^{6}$

Other new Camphillers came through the formal volunteer programs that proliferated in the 1960 s and 1970s. Bernie Wolf, who arrived at Beaver Run just a few years after Sherry Wildfeuer, came as part of his education at Antioch College, which requires students to complete off-campus internships, and he wound up staying for decades. Camphill's relationship with Antioch deepened when its study-abroad coordinator, Gwen Gardner, spent three months of her sabbatical recuperating from an illness at the Sheiling Schools in Ringwood. ${ }^{69}$

Jonathan Reid came to Botton Village in 1980 through a conservation program that placed students for a week or two of tree planting. He stayed because of the 
intensity of his meetings with people, and the concreteness of the tasks they undertook together. "My first impression was, here are people doing something. ... That sense of purposeful activity was really strong. And that was a kind of first phase. After being in university, the relief of being able to actually dig a ditch or cook a meal. And the phase 2 was, well, who are the people who are doing this activity? And then you [having] very strong meetings with the so-called learning disabled people. A very direct way to have a meeting. There is no pussy-footing around in how you meet. It is very direct. . . . then phase 3 is in a way to do with the anthroposophy. What is in the back of all this?"7o

Bernie's and Jonathan's experiences were possible because Camphill had begun working with international voluntary programs in the 1950s. In the summer of 1955 the International Voluntary Service for Peace (IVS) brought a "camp" of twenty volunteers to Camphill Glencraig, which had recently celebrated its first anniversary. "Penetrating the unconquered parts of the estate," they built a bridge, repaired a cowshed, and heightened a seawall. One of their number, Bill Boyd, was inspired to become a Christian Community priest. ${ }^{71}$ IVS had been founded in 1931 by Swiss pacifist Pierre Ceresole, who believed that countries that exchanged volunteers would be less likely to go to war; in 1939 the British government recognized it as an alternative placement for drafted conscientious objectors. ${ }^{72}$ IVS is the ancestor of some of the organizations that still guide young people to Camphill placements; other such organizations have roots in the Waldorf movement and other anthroposophical initiatives.

As baby boomer coworkers dug into what was "in the back" of Camphill, most embraced anthroposophy as their personal spiritual path. Some valued anthroposophy simply because it was the source of a mode of communal living they cherished. Others saw it as the answer to a deep spiritual yearning. "Once I met Camphill," one coworker told me, "I had a feeling that I had found something that is mine but I didn't know what it was. . . I I didn't even have a question. I just knew intuitively that there is something that is for me."73

That coworker was part of the minority of baby boomer Camphillers who encountered anthroposophy first, and were then drawn to Camphill because it offered the chance to live anthroposophy more holistically. "When I met anthroposophy," he told me, "I instantly recognized, this was it. . . This was the center of my life." Camphill was a place where anthroposophy "was not only a study," but "a situation where all the different aspects of anthroposophy would potentially be utilized." ${ }^{4}$ Similarly, baby boomer Michael Babitch spent ten years "assiduously reading and studying" anthroposophy before he and his family moved to Camphill. He found Steiner's ideas to be relevant to his work as a team leader in a program for preschoolers and infants with disabilities, but he was increasingly troubled by the way "the whole person was being shattered" by professional specialization and conflicts between labor and management. At Camphill he was inspired by the presence of others in his generation who were even "more 
steeped in anthroposophy than I was," but above all by the "social impulses and the social mission." As he took on management roles, he was continually reminded that "leadership can come from the spiritual world to anybody at any time. You'd better be open to listening to any human being. There are villagers who in large circles have said something that has been the most incredible insight and just what needed to be said." 75

Whatever factors brought baby boomers to Camphill, most discovered leadership opportunities within a growing movement. For people who joined the Camphill seminar in the 1970s or 1980s, each year could bring a new task: one might be assigned a small group of students or villagers in the first year, an entire class or household by the end of the seminar, and be asked to help launch a new Camphill place a year or two after that. As a consequence, one coworker told me, "you felt that you were important. You felt, gosh if I don't do this work what's going to happen to those children or the community?... There weren't masses and masses of coworkers." When she was asked to take on a class of high-energy six-year-olds for the first time, without any previous experience with such young children, "it was extremely challenging. . . . But at the end of my first year I thought, gosh, if I leave that class they will really be thrown back to the beginning again, they will suffer, they won't be able to build on the steps that they've made. I'd better stay with them." ${ }^{76}$ Baby boomers who wanted to deepen their training in other aspects of anthroposophy could do so within the context of Camphill, as seminars in various fields were established by Camphill communities. The eurythmy school founded at Ringwood in 1970, for example, expanded into a four-year training by 1978, with the first two years offered at Ringwood and the latter two at Botton Village. ${ }^{77}$

These experiences equipped the baby boom generation to move into positions of community-wide leadership in the late 1980s and 1990s. One of the founders of Camphill Devon offered a vivid portrait of the first years of that Camphill community, when she and her husband were just twenty-two. "Within five months of starting the community we had a baby as well as ten adults with learning disabilities. Frankie was out in the farm all day ... milking the cows twice a day and starting the process of growing crops for the community." Because England had rapidly deinstitutionalized persons with special needs in the 1970s, the community grew to include forty adults with intellectual disabilities in its first two months. This created a "beautiful" dynamic in which each villager "had to rise up to play a part in it, much more so than being in a care home. Each one was called upon to do as much as possible to help the whole." ${ }^{78}$

Upon arriving at the newly founded Pennine training college in 1983 at age twenty-four, coworker Ruth Tschannen was amazed to be among people who took her seriously. She was asked to cook for fifty people, alongside four people with special needs and one other coworker. After nine months, she began running the garden, producing vegetables for the same fifty people, and in her third year she started the basket workshop. "I could do anything. They trusted everything to 
me at a young age." Indeed, she was one of the older people at the Pennine: the students were college-age, the other new coworkers were all nineteen, and the two seasoned couples who mentored them were just in their mid-thirties. "That is the wonderful thing in a pioneering community," she summed up. "There are so many different opportunities to do things. ... And then suddenly, you've become an expert." 79

As the new Camphillers took on more responsibility, they deepened their ties to the older generations. Most baby boomer coworkers whom I interviewed stressed the openhearted way in which older Camphillers bridged generational differences. When younger coworkers sang Bob Dylan's “The Times They Are A-Changing" at Glencraig's Whitsun celebration in 1975, observed one participant, the "Mothers and Fathers were here to learn to understand." 80 "I was quite wild when I first came," recalled coworker Stephen Sands. "I came out of the hippie culture, and was by no means looking like I had emerged from the cultural heights of middle Europe. But I was tolerated in a nonpatronizing way. I was challenged very stringently to clarify what my real views and what my real aims in life were. And having been challenged, I was challenged also to either work with what I was meeting and change it by becoming part of it, or come up with something better. And I would say that to this day I haven't been able to come up with something better." ${ }^{81}$

Mutual transformation was possible because older Camphillers, for all their differences, were inspiring and open to dialogue. "I was encouraged to express my questions and go to somebody with more experience," mused Steve Lyons, wondering if similar opportunities for dialogue are available in Camphill today. ${ }^{82}$ Sherry Wildfeuer recalled her biodynamic mentor at Beaver Run, a woman in her late seventies known as Granny Lueder. "I adored her. .. . She was all hunched over and I would go and help her just to carry her basket, because she grew zucchinis like cudgels. . . . I could see that she saw more than I was seeing. Just looking over her shoulder I could see that. That was the first inkling I had. That was just a totally new thought for someone who grew up in the suburbs." ${ }^{3}$

Baby boomers who spent time at Botton Village, by then the largest Camphill place in the world, spoke with particular appreciation of the leadership exercised by Peter and Kate Roth, as well as others of the earlier generations. One coworker who arrived at Botton in 1977 told me that he met both "a very strong group of older people, of hugely diverse nationalities, cultures, and interests," and a "quite intense group of people about our age" who would remain close friends even after they scattered to other Camphills. They were all "extremely fortunate in landing at Botton where there was a very strong culture of empowering the younger generation, giving them a little bit too much responsibility ... [and] allowing them to fail." As he aged and found himself "on the other side of the table," he became ever more impressed by the risks his mentors had taken on behalf of him and his peers. "There was a spiritual security . . that allowed them that largesse." "Peter Roth," elaborated Jonathan Reid, a coworker who arrived a few years later, "had the knack of devolving responsibility very rapidly and incessantly to other people.... Quite 
young people could find themselves running a garden or a farm in very little time." Moreover, "Peter was also always asking for other people's opinions. New people's opinions. To get them really included in the community's sense of itself. So on one hand, through that founding group you met very strongly the principles of Camphill, but at the same time there was this other gesture of really encouraging new people's input and creativity and so forth." ${ }^{5}$

Older Camphillers also welcomed members of the baby boom generation by inviting them to participate in Camphill's inner community. It experienced periods of intense flourishing, punctuated by a few crises, in the 1960s and 1970s. The opportunity to do one's spiritual work with other Camphillers exerted a powerful attraction. "You had meetings on a special night," explained one participant with reference to the 1960s. "Not that you saw spirits, but you knew that everyone had done something." ${ }^{86}$ Joining the inner community, Russ Pooler added, "was a big step because then you in a sense really took on Camphill. . . . Not just the outside work. You took on the inner work as well. . . This inner work you do has faded away a lot in recent years, but certainly in those years, the late seventies, eighties, boy it was really strong. It was what kept Camphill going and got it through all these things." ${ }^{7}$

The process by which individual coworkers join the inner community has varied from place to place as well as over the course of time, and as a consequence my interviews have generated a somewhat blurry picture of the process. Some people told me that it was routine, in the 1970s, for coworkers to be invited to join the inner community after one or two years; others insisted that no one is ever invited unless they take the initiative to inquire about it. It does seem clear that the 1970 s were a time of transition for the inner community. It was less secret and less dominated by the founders than it had been in the past; at the same time, it was more central to the overall culture of Camphill than it would be in the future. For coworkers in the 1970s, one person explained, joining the inner community was "very important" but by no means automatic. "At a certain point after maybe four or five years, older people who I respected and who were helping me . . . suggested that I might like to think about joining that. ... But the inner community ... is not something you just join. . . . For me it was incredibly much part of this process of self-knowledge. And learning my own weaknesses and how to manage myself and manage my frailties and how I could get help and support from other people who had joined the community." 88 Another baby boomer told me that he had joined the inner community within half a year of arriving at Camphill. "When I finished my training I recognized if I really want to work in the world out of anthroposophy, I need to connect to the roots of that work, the wellspring of that work." He joined both the First Class of the Anthroposophical Society and the Camphill inner community, "as that circle of people who carries this aspect in the Camphill context. It was not so much a process as it was an instant recognition and a request to be granted that." 89

The inner community evolved rapidly during the years that baby boomers were arriving. In 1964 the sectors were renewed, with each one understood in relation 
to one of the windows of the Goetheanum, a building designed by Rudolf Steiner that is the center of the Anthroposophical Society. In 1972 the sectors began opening up to one another, to enable greater sharing of the spiritual fruits of their inner work..$^{\circ}$ In places like Botton, the structure of the inner community gave shape and intensity to the outer community as well, giving it the feel of a spiritual university in which coworkers were continually involved in study groups of various sorts. ${ }^{91}$ This had lasting effects, said one person who came to Camphill in Germany around the same time. "When you meet old Camphillers, there is a certain kind of flair around or energy around, the way they speak, the way they do things, the way they embrace different things that belongs to the Camphill Community. . . . It is like a holy thing. How to embrace a house. How to embrace guests. How to embrace when you speak." ${ }^{2}$

Despite, or perhaps because of, the intensity of inner community life, the community members chose to enact a "quiet year" in 1978, admitting no new members during that year or the next. The inner community was then reorganized on a new basis, with older members going through a new admission and many baby boomers joining for the first time. In keeping with Rudolf Steiner's vision of a threefold social order, each member was asked to devote special attention to either the economic, the political, or the cultural sphere. Gatherings and conferences were devoted to distinctive themes. ${ }^{93}$ At the same time, it became acceptable for coworkers to participate fully in the Camphill Movement without joining the inner community. Christoph Hanni, a baby boomer who arrived in the 1980s, told me that he was aware of the inner community from early in his time at Camphill, "but I didn't really feel, this is something I just have to do. I was quite happy not to be. I didn't bother about it." After seven years he joined the Anthroposophical Society, then the inner community after three more years. "I thought, now I know I'm going to stay here, I need to be part of this, I can't just live here and not be a part of it." By that point, there was a clear division between "the people of the inner community, the stalwart anthroposophists who would go to a workshop every evening and do a meditation every day, and have that as their main driving motivation" and "all the Buddhists, people who had a very different outlook."94

Camphill also inculturated baby boomer coworkers in the 1970s by holding "youth conferences," designed to give newcomers a sense of the movement as a whole. Since the founders had been an anthroposophical youth group in Vienna, this was a natural way of embracing the new energy of the young while staying connected to Camphill traditions. Conferences enabled the most committed baby boomers to meet their counterparts from other Camphill places; at the same time, they learned about Camphill's history and traditions from older Camphillers who offered workshops. The restructuring of the inner community grew out of youth conferences held in Scotland, Germany, Holland, and the United States in the summer of $1980 . .^{95}$ Participants often described the conference experience in glowing terms, sometimes trying out the new vocabulary of anthroposophy in order to do 
so. After a conference at Christmas 1974, one participant wrote that its spirit had "penetrated, as yeast does a well-worked lump of dough, into the conduct of everyday life in the various houses and neighborhoods" of the host community. Another made the same point by invoking the "golden process" of alchemy, which "manifested itself in the morning meetings where, in groups, we listened carefully to one another and with our impressions contributed to an understanding and feeling for such things as: three-foldness, alchemy, the main social law, gold and more." 96

Baby boomer Michael Babitch discovered Camphill at an anthroposophical youth conference at Threefold Community (an intentional community in New York, inspired by anthroposophy, that predates the Camphill Movement). Up until that time he had known anthroposophy only through a few individuals whom he found to be deeply impressive. Now "I was experiencing these remarkable people doing remarkable things, and remarkable workshops. There were I think six hundred people there." Though he didn't realize it at the time, he also witnessed a significant step in the healing of the schism within the Anthroposophical Society, as one workshop featured prominent leaders from both sides. ${ }^{97}$

Camphill also marked the arrival of a new generation by creating a new newsletter. The Cresset, which ran from 1953 until 1972 and carried long articles that emphasized abstract ideas, reflected the personalities of the founders and the intellectual culture of midcentury anthroposophy. Karl König contributed frequently, and Anke Weihs edited the Cresset up to the end. The Camphill Correspondence, launched in 1975, was oriented to keeping the by-now numerous communities in conversation with one another, and with the world beyond. In its inaugural editorial, Richard Poole stressed the importance of outreach with an image drawn from the final issue of the Cresset: "Anke Weihs used the image of a community as a river, taking the source from a tiny, obscure spring high up in the hills, finally to reach the salt waters of a rapidly-changing world, the great ocean of society." 98

From the 1970 s until the present (2020), baby boomers have been the numerically dominant group among Camphill coworkers. Already in the 1970s, they assumed much responsibility as teachers, house parents, and workshop leaders. Most Camphill places were either founded by baby boomers or included baby boomers among a circle of founders. Yet the process by which baby boomers assumed primary leadership roles in the largest Camphill places and in the movement as a whole was a stormy one, with more conflict and disruption than occurred in the wake of Karl König's death. At Botton Village, for example, Peter Roth did a great deal to cultivate the leadership qualities of the baby boomer generation, but most of the strongest leaders in that generation subsequently departed for newer Camphill places. When Roth stepped back from leadership, one subgroup of baby boomers, with a fairly charismatic leader, sought to take leadership of the village, but met a backlash from others who found their vision to be "a little bit syrupy and based on sentiment and emotion" (in the words of one of their opponents). ${ }^{99}$ Camphill Vidaråsen experienced similar challenges, despite the fact 
that its founder, Margit Engel, had a different personality than that of Peter Roth: where he had been perhaps overly eager to empower others, she struggled to follow through on her intention to allow leadership to devolve. But, like him, she had encouraged the strongest baby boomer leaders to go elsewhere. ${ }^{100}$ Newton Dee Village, likewise, experienced such an intense conflict in the 1990 s that they brought in an outside consultant to help them resolve their difficulties. As at Botton, the conflict was not between baby boomers and the previous generation, but within the baby boom generation-though in this case it did by at least one account pit those who favored far-reaching changes against those "who still very much clung to the traditions of the older group."101

The baby boomer style of leadership within Camphill has a few distinctive qualities. First, boomers place an especially high premium on shared leadership. The person who told me about Margit Engel's difficulty relinquishing authority at Vidaråsen, for example, also noted that "I like to be part of a team. I don't like to be a leader." In many Camphill places today, day-to-day authority is exercised by a "management group" rather than by a "named manager," despite the fact that social care authorities prefer to communicate with just one leader. This preference reflects the egalitarian culture of 1960 s social movements, but it is also rooted in anthroposophical tradition. Waldorf schools are ordinarily governed by the "collegium" of all the teachers rather than by a nonteaching administrator. The Anthroposophical Society has been governed by an executive committee ever since Rudolf Steiner's death, though the practice of also naming an individual chairman continued until 2001, which was the first year in which baby boomers constituted half the committee's membership. In general, anthroposophists have been comfortable with the charismatic leadership of individuals but much less comfortable with bureaucratic structures that vest ultimate authority in a single person. In the 1990s, baby boomers witnessed the death or retirement of many individuals who had exercised charismatic leadership, either as the founders of specific Camphill places or as members of the movement's founding generation, and for the most part they chose not to emulate the leadership style or roles of those individuals.

Baby boomers in Camphill also relate to anthroposophy differently than do those from the previous generation. This is not to say that they aren't personally committed to anthroposophy. Most long-term coworkers of the baby boom generation either participate in anthroposophical study groups or have done so in the past; most have read a great many books and lectures by Rudolf Steiner; most have, at some point in their lives, engaged in anthroposophical meditative practices. The majority of baby boomer coworkers who arrived at Camphill in the 1980 os or earlier and are still there today are members of the inner community. Yet they have, often by conscious choice, presided over a transformation in which a deep connection to anthroposophy is no longer expected of coworkers from subsequent generations (or, for that matter, of baby boomer coworkers who arrived in the 1990 os or later). 
One baby boomer whose family heritage extends through three Camphill generations described this transition to me as a mirror of changing spiritual dynamics within Western culture as a whole. Between the 1960s and the 1980s, she said, all the "common traditions" of the past were coming to an end, and "people were very much on a search to break out of stuck modes and habits." These seekers perceived intentional community as a "new thing" that would supplant the old traditions. If the community they happened to find was Camphill, it was natural for them to embrace "the spiritual esoteric path of anthroposophy" in its entirety. But as older traditions lost their power, and an eclectic New Age spirituality took their place, spiritual seekers of the 1990s and beyond were no longer "looking for a core belief that will sustain the breakup of tradition, because we are so used to living on fluid ground, or shifting soils, that we don't necessarily need that from outside." These people still want spirituality, she emphasized, but "they are open to anything and they are not willing to commit any more to one particular path." What's more, she said, baby boomers are deeply attentive to the voices of their own children, who "are saying, don't come and tell us this is the only way. Show us who you are, be authentic, live your life, and we will come and ask you." ${ }^{102}$

Baby boomer Camphillers have responded to the changing spiritual climate in a variety of ways. Many retain a daily practice of meditation and participate in the Camphill inner community, in anthroposophical study groups, and in Christian Community congregations. Nearly all the people who sustain Camphill's liturgical life as Christian Community priests or as lay "service holders" for the Festival of Offering (a weekly ritual that does not require a priest) are part of the baby boom generation, or slightly older. Most of these people are happy to talk about anthroposophy with anyone who asks, though they rarely bring up the topic unbidden.

Other baby boomers might be characterized as apostates from anthroposophy who have remained loyal to Camphill. "I went through a time when I was reading a lecture a day," one told me when recalling his early days in Camphill. "I was being a good boy. There's a lot of Steiner's ideas which for me are immensely important and I think very important for the world, but I would only ever say I'm an anthroposophist with a small a." ${ }^{103}$ A fellow member of his community told a similar story with more detail: "I think a lot of us anthroposophists, this is a confession, read Steiner passionately, ardently, for a number of years, and we bought more books by him than we ever possibly could read. Our shelves are full of them and they are all gathering dust. We all got tired of it, couldn't cope with it, that's too complex, that's weird." He was particularly influenced by the discovery of other authors, notably Ken Wilber and Rupert Sheldrake, who presented ideas similar to anthroposophy in newer and more accessible language. Though he remains "intensely grateful for having found anthroposophy and Camphill," his real passion today is for intentional community in all its forms. When other Camphillers want to discuss Steiner lectures from the 1920s, his only reply is "what do we have to say to society now?"104 
Another baby boomer coworker, not quite so alienated from anthroposophy, observed that many in her generation still carried scars from the heavy-handed way in which they had been introduced to anthroposophy.

There is still a cloud hanging over people who are now my age or a bit younger than me . . . who fear they have been pressurized into things, they have been pushed into things, there is only one way to think and if you think differently you are a bad Camphiller. .. . There are some who embraced it very much but then really almost turned against it after a while. ... But stayed in Camphill because the work with the children is important to them. And others who still embrace it, but . . [ [are] very careful ... not to do the same as was done to us. ${ }^{105}$

A similar hesitation can be found in many aspects of baby boomer leadership in Camphill. Some baby boomers, raised in Camphill, have founded their own communities but declined to affiliate these formally with the movement. Another baby boomer, who came to Camphill as a young adult and participated in a very strong cohort of coworkers at Botton, left the question of affiliation with Camphill open when he and his wife founded a new elder community in England. "We came here out of a wish to develop certain ideas within Camphill and we founded the community here. But we were unsure at the time whether it would be a Camphill community. And so we dissolved the outer forms. We stopped having Bible Evenings, graces at the beginning of meals.... We wanted to live with the community impulse and decide a bit later whether it should be a Camphill community." Even though their ultimate decision was to identify as Camphill, giving the community freedom to evolve in its own way was an important value. ${ }^{106}$

When I ask baby boomers about the task of handing Camphill traditions on to the next generation, many begin by comparing themselves unfavorably to the founders. "The generation before me were very sure of themselves," explained Russ Pooler, at Newton Dee in Scotland. "And we came along and we weren't sure of ourselves." ${ }^{107}$ A coworker in Ireland elaborated that "the original founders had the pioneering thing. They had by blood, sweat, and tears brought the community into existence, and that gave us huge respect for what they were doing. We inherited it, and it became affluent in our time, and we were seduced by the affluence .... My generation has failed to fill the next generation with that enthusiasm to want to take it into the future."108

Such comparisons have another side. Russ Pooler added that the founders could be heavy-handed. "They forced Camphill to be like this. It caused a lot of problems, a lot of pain, and you don't do that anymore." ${ }^{109}$ The other coworker just cited said that although "the first generation didn't make a moral compromise," this was to the detriment of some things. "To be a staff child in Camphill in [the early] days was not nice, because our parents gave everything to the development of the community." Even the people with special needs, she added, "had to toe the line with the founding members," while her own generation has "been much 
more tolerant, and the next generation even more so." ${ }^{110}$ Similarly, the last in a long line of baby boomers to serve as president of the Camphill Association of North America saw herself as ideally suited for generational transition precisely because she did not have a powerful vision to hand on. "I thought I could be that transition president because I am not a big person. I would not impose my ideas and impressions and vision on what the association could be, but allow it to have an evolutionary phase where the young people could step in and bring their new impulses and their new way of working." ${ }^{11}$

The ambivalence makes it easier to understand why many Camphillers are not confident that the current generational transition will be as successful as the previous two-but also why confidence is just the thing that is needed. In order to inspire the millennial generation, baby boomers must muster the same enthusiasm and idealism that they received from their predecessors, and they must express this enthusiasm not only for the work of their predecessors but also for their own work and for the changes they have made. Perhaps paradoxically, they must convey a sense that Camphill as it exists today is worth carrying into the future, and that it is in continuity with the Camphill of the founders.

The current transition is also complicated by dramatic changes in the organizational structure of Camphill, which is more socially complex today than it was in 1980. The total number of persons involved in Camphill has perhaps reached a plateau, while the range of roles they play has diversified. The number of nondisabled adults who have lived at Camphill for more than three years and who expect to continue living there indefinitely has declined significantly, especially if one excludes those adults who are of retirement age. They have been replaced by employees who perform functions ranging from janitorial service to executive direction, and by "young coworkers" who come to Camphill for a gap year or specialized training, with no intention of staying long-term. As the social stigma of disability has declined, parents of the residents with special needs are more likely to participate in the daily life of Camphill, as are residents of surrounding neighborhoods. Many Camphills also sponsor day programs for persons with special needs who reside elsewhere.

All of this makes it much more difficult to achieve the intergenerational dialogue that was so important to the previous transition. "We are isolated from each other," a Camphiller named Steve Lyons explained, because roles are more differentiated and professionalized: "The land people don't talk to the teachers in the school. Or in an adult community the workshop people are not talking to the folks who have an overall view of the governance issues." 112 Another mused that "I just hope I ... can live up that kind of openness [that he had experienced] when people come here. By really listening to who they are.... And asking the same question, if you think this isn't what it should be, what should it be?"113

In the past, the most seasoned Camphillers were available for conversation in the kitchen, the workshop, and the garden, amid the daily rhythms of Camphill 
life. But with the increasing of state regulation, many of these people today work in central offices, interacting with government inspectors, social workers, and donors. These tasks separate them from the younger generation and make the younger generation less likely to trust them as mentors who have performed the same tasks the young people are doing now.

Perhaps the most significant Camphill response to this challenge has been the creation of formal structures for intergenerational dialogue. In the past decade, many Camphills have expanded the seminar programs in which young coworkers participate, and in both Scotland and the United States it is possible for seminar participants to earn a BA degree primarily through experiences within the community. This expansion only partly offsets the decline of the inner community, which today includes only a handful of coworkers who are under forty and only sporadically plays a vital role in shaping the life of Camphill. The kind of informal handing on of the torch that once happened within the inner community must now find new spaces.

Ultimately, the current generational transition may be both less conflictual and less successful than the one that went before, simply because of the baby boomers' reluctance to be directive. At Newton Dee, baby boomer Simon Beckett told me that there was more harmony in the current transition and more honesty in the previous one. ${ }^{114}$ His perception was echoed by Jonas Hellbrandt, a Gen Xer at the same community. Because "the baby boomers come from a culture where it is very difficult to tell people how to live their life," his generation has inherited a "diluted" consciousness of how anthroposophy informs Camphill lives. When it comes time for them to pass on the tradition to a fifth generation, they "will have to make an effort to be informed and ... more conscious about [how] the ideas of anthroposophy ... live in our day to day life." ${ }^{115}$

\section{A MISSING GENERATION}

I began spending time at Camphill Village Minnesota in 1999, when I was thirtytwo and starting a career as a college professor. Most of the coworkers I met were either substantially older or younger than me. Several were baby boomers who had met as young adults at Camphill Copake in the 1970s and migrated to Minnesota in the 1980 or or 1990s. One couple who had recently left the village and moved to a nearby town were former staff kids from Copake, a few years younger than the others but still within the baby boom cohort. Two other baby boomer couples, without a deep background in Camphill or anthroposophy, had been raising their children in the community for the past decade or so. The other major group of coworkers were so-called "young coworkers," many of them German and fresh out of high school, who spent only one or two years as part of the community. In between were two coworkers who were, like me, born in the late 1960 s and thus part of the small cohort known as Gen X. They were both single, and at times 
preoccupied with the question of whether they would sacrifice their chance to have families if they stayed in Camphill long-term. Meanwhile, the villagers with special needs were chronologically balanced, with persons born in the 1960 and 1970 s perhaps the majority. This may have been because the village was started in the early 1980s, as Gen Xers with disabilities were reaching adulthood and looking for residential placements.

Since 1999, I have seen a similar pattern in many other Camphills, especially those that are far from urban centers. In places that were founded earlier than Camphill Village Minnesota, the "missing generation" phenomenon applies equally to Camphillers with and without intellectual disabilities: many villagers arrived as young adults in the 1960s or 1970 and stayed on, leaving relatively few openings until they began moving on into the newer elder communities. Still, it is the absence of Gen-X coworkers that most frequently sparks expressions of anxiety about Camphill's future. "It is fairly consistent," said Camphill Scotland staffperson Neil Henery, "that there seems to be a small group of aging coworkers who have leadership roles ... and a larger population of transient and younger coworkers. . . The distance between the two . . . is getting quite acute." ${ }^{{ }^{116}}$ Even places that are proud of their success in retaining members of the millennial generation acknowledge a generation gap, as one Gen Xer at Newton Dee told me: "Really my age there are not so many, there are quite a few who are already ten years on, late fifties, early sixties, and then there is this strong group of younger people."117 Another of a similar age who had first come as a young coworker said, "When others talk about young people, they don't include me. ... I guess I am just there in the middle."118

Camphill places with strong Gen-X leadership are conscious of their exceptional status. When I visited Camphill Grangebeg in Ireland, I noticed that most of the community's leaders were in their late forties, and I soon learned that conflicts had driven the community's baby boomer founders away. "Obviously in Grangebeg you are talking of a Camphill that has gone through some very hurtful periods of time," explained Tobias Pedersen. "To birth Grangebeg has been so painful on the human side. It has cost relationships. People have come and have gone." ${ }^{119}$ Another Grangebeger described this situation as "a blessing and a misfortune." On the one hand, they are less frequently "paralyzed" by older forms of life, but on the other they miss a certain "wisdom" that surrounds Camphills with more generational diversity. Most of the coworkers "had extreme karmic struggles in previous projects," and as a result "we have learned to fairly readily accept one another in our inadequacies and irritating habits... But it also means that we are possibly blindly leading one another."120

For some Camphillers who are rooted in anthroposophy, the absence of a generation is a spiritual phenomenon that requires a karmic answer. Perhaps, one person told me, the Camphill impulse was the work of "a particular grouping of souls," and "maybe that group has all arrived and there is an end to it.... Another 
possibility is that their earthly development ... is getting harder and harder to connect with one's pre-earthly intentions, and [so] people don't find it anymore." ${ }^{121}$

Mundane factors have also contributed to the scarcity of Gen-X coworkers in Camphill. First, it is a smaller generation: birthrates in Western Europe and the United States declined precipitously in the 196os. Second, the slowing rate of economic growth in the $198 \mathrm{os}$, coupled with the rising cost of higher education, meant that fewer middle- and professional-class people felt sufficiently secure economically to undertake an open-ended search for a communal alternative to mainstream employment. A third factor was the rise of "gap year" volunteerism in Europe in the 1980s. This was driven by a change in the implementation of Germany's military conscription law. Prior to 1983 , conscientious objectors who wished to perform alternative civil service had to go through a cumbersome application process; after 1983, the process was streamlined and virtually all requests were approved. As the numbers of young German men performing volunteer service between high school and college increased, their peers who were female or from other European nations followed suit. By the 1990s, formal placement organizations for gap-year volunteers proliferated, including two that focus specifically on anthroposophical initiatives. The larger of these, Freunde der Erziehungskunst, currently has more than a hundred volunteers at Camphill places in the United Kingdom, thirty in Ireland, and fifty in the United States. ${ }^{122}$

Camphill initially experienced gap-year volunteering as a boon. It provided a stream of willing workers, many of them contemplating careers in education or social work. Only gradually did they realize that these young people were not like those who came before: people who were taking a year off before university were less likely to make a long-term commitment than those who had already finished school, or who had dropped out of college in search of an alternative to the mainstream. And those who came after college felt out of place in communities that catered more to teenagers and empty-nesters. Recalling her own arrival in the 1990s, one person recalled a twenty-two-year-old companion who said, "She loves it here, she would love to stay, but she would really struggle because all the other people were the age of her parents." ${ }^{123}$ In recent years, many Camphills have taken steps to increase the numbers of gap-year volunteers who become long-term Camphillers, but these strategies arrived too late for Gen X.

Another factor that has limited the role of Gen Xers in Camphill is the declining vitality of Camphill's inner community. Prior to the 1980s, it was common in many Camphills for coworkers to be invited to join the inner community when they completed the seminar, or when they took on primary responsibility for a household or workshop. In other places, potential members had to take the initiative to ask about it, but this happened commonly because all the older coworkers with whom one might interact were already inner community members. By contrast, almost everyone I spoke to who joined the inner community after 1985 said that they had to seek it out and that the process took many years, in part because 
many of the seasoned Camphillers were either not members of the inner community or no longer actively involved in it. One person who had been in Camphill for almost thirty years when I interviewed him in 2013 told me that he hadn't joined the inner community until after 2000. "It was actually my initiative, yes, because by that time I realized that I was sufficiently committed that I wanted to give expression to that by joining the inner community."124

Marjan Sikkel, a baby boomer whom I met in Scotland, described a more difficult path into being a member in the inner community. "I asked myself if I could become one," she said, then added that she was refused admission to the inner community in one Camphill, a fact that shocked her friends at the next place she joined. She also hesitated to seek out the inner community because her impression was that it did not live up to its own ideals. "I think the idea of an inner community where people hold the flame ... is really beautiful. But then I heard that actually they were fighting inside the Camphill community with each other. I thought, 'That's not so beautiful, is it?"' She chose to join anyway because she realized that conflict is inevitable in any spiritual community, and that working through the conflict is part of the spiritual task. ${ }^{125}$ A Gen Xer in North America said her path to the inner community was slowed by her perception that, with increasing administrative responsibilities, baby boomers were no longer engaged in the real work of Camphill. "When I was a coworker here in my mid to late twenties, I had a little bit of a perspective that it was an older generation who are not really standing in the life. They are not really working with the children ... and now they are telling us how it is done? You get that picture, right? A very black-and-white picture of a twenty-something-year-old person." Inner community members seemed to her to be "much, much older," and "I could not really see what they were doing." Finally, someone took what was a "very unusual" step and asked her to consider joining - and even then, her process took two or three more years. ${ }^{126}$

Similar challenges prevented another Camphiller, herself a former staff kid, from joining the inner community at all. It wasn't "for lack of trying," she explained. She knew that the path in was to "approach somebody with your interest," and so she tried speaking to people her parents' age whom she knew to be inner community members. "They've all said, oh, no, don't talk to me about it, go and talk to so-and-so who is like the grandma or grandpa in the community. And after two such incidents I decided, well, actually I'm not going to do that again. I want to talk to somebody who is not the grandma or grandpa. It is not because I am not interested in talking to them, but because I think it is not their job to talk to me. The people I approach should be doing that, and they are not confident enough for whatever reason." ${ }^{127}$ Her spouse, Tom Marx, added that in their neighborhood the inner community members had recently "decided that they are not going to meet anymore because they have decided that that element of Camphill life is no longer wanted." ${ }^{128}$ Another Gen Xer observed that while "a lot of people always take for granted" that she is an inner community member, she has never felt 
quite right about joining. "The thing is, I don't quite understand it myself. There is something, when something goes beyond a certain point into the really esoteric realm, where I feel I don't want to, or I shouldn't go there. . . . It is something very holy and precious and I'm not quite sure whether I'm just a coward or whether it is also not for me." ${ }^{129}$

Even when Gen Xers find their way to the inner community, they may struggle to know what to do with it once they arrive. Guy Alma told me that he had been in Camphill for five years before joining the inner community, and that most of his age peers made the opposite choice because "it just wasn't relevant to them." "There's nothing that you would outwardly miss by not joining it," Guy observed, then said that "early on when I joined the community, it was a little bit like I was in a big building where there was music playing and I could hear it but I couldn't find my way to the room that it was in. .. I think my generation and the people that are coming up now were handed something-I do feel we were handed a torch. But we were handed it somewhat tentatively. We were given it but not really told what to do with it. I found that difficult. I found that exciting." ${ }^{130}$ I heard some of the same excitement from Ruairidh von Stein, a Gen Xer who grew up in Camphill and spent much of his young adulthood in the movement. Ruairidh did not fully embrace anthroposophy until middle age. He joined both the inner community and the Christian Community around 2006. "Some people do it within three months, and some people take their time gradually. I took two years, and I was very grateful that I was led into the community-you get led in by a friend who leads you into the community, you share your life story with the friend. That friend then tells your life story within the community setting, and you then write your own vow." For all the support he received, Ruairidh still described the inner community as "a lonely path" because it is not visible outwardly. "But I felt it was very important to nurture and carry that within. The spiritual part of the community is very essential to keep up." ${ }^{31}$ These words epitomize the challenge of the inner community today: if it is no longer providing that depth of commitment for the majority of Camphillers, what will?

One factor that offsets the absence of Gen-X coworkers is that this generation is well represented among Camphill employees. There is a direct connection between these facts. Camphill began employing large numbers of people in the 1990 s and 2000 s because they were having trouble recruiting long-term coworkers, and many of the people on the job market in those years were Gen Xers. Yet it continues to be rare for employees to play a central role in shaping the future of the movement as a whole, and this pattern diminishes the visibility and influence of Gen Xers.

Just as Camphill town communities and training colleges emerged during the years when baby boomers were streaming into the movement, so one final type of Camphill place coincides roughly with Gen X. But it underscores that generation's low profile, for this type of community was created largely by baby boomers, and 
was initially populated by even older people. I refer to the "elder community" centering around the unique needs of older adults, including but not limited to retired coworkers and adults with intellectual disabilities. As early as 1973, the Grange Community in England hosted a conference on the challenge of aging villagers, where participants explored the extent to which care for the aging could be incorporated into the "work" of a traditional village, and whether other forms were needed. The original idea-of creating a "sanatorium" at one Camphill to which aging villagers from other places might relocate-proved difficult to get off the ground. ${ }^{132}$ The first elder community, Simeon, was established in Aberdeen in 1984-forty-five years after Camphill's beginnings in that city, and thus at a time when people who might have arrived at Camphill as teenagers in the early years were moving into old age. The first elder Camphill in the United States, Camphill Ghent, was established up the road from Camphill Copake around 2010, at a time when the number of elderly villagers and coworkers at Copake had grown so large that the community was struggling to open up any spaces for younger people. Yet Simeon and Ghent provide only moderate relief to the aging challenges of nearby villages, since most of their residents did not previously live at Camphill. Other large Camphill villages, notably Vidaråsen in Norway, have designated specific houses as "care homes" for the elderly within the context of multigenerational village life.

Elder communities draw on a heritage of anthroposophical work for the elderly that has taken place outside Camphill for decades. In Spring Valley, New York, the Fellowship Community is a Camphill-like village specializing in care for the elderly, but without a specific focus on disability. It was founded in 1966, and its campus directly adjoins that of the Threefold Educational Center, a loosely organized intentional community that has anchored anthroposophical endeavors in the United States since its founding in 1926. Drawing on such examples, Camphill elder communities generally insist that they are designed as places where the elderly can be fully included in multigenerational community-just as other Camphills are not exclusively for persons with learning difficulties, but places where people of all abilities can freely share their gifts with the world. As one coworker at Simeon put it, their mission is both "to allow each one to meaningfully live out the last years of their life" and "to allow younger people or other people to be involved with older people and to bring about this mix of generations." This multigenerational mission is made easier by the fact that Simeon shares a backyard and a community center with Cairnlee, the training college that is part of Camphill Schools Aberdeen, ensuring that some of the youngest and some of the oldest Camphillers pass by one another as part of their daily routine. Simeon also seeks to make its community accessible to the loved ones of its residents, knowing that "all the threads and connections of their lives come together in family and friends who surround that person at the end phase of life." ${ }^{133}$

Elder communities help Camphillers live out an important implication of anthroposophical teaching about karma and reincarnation: that death need not 
be a catastrophe, but can be embraced as a joyful transition to the next stage of spiritual development. To maintain personal connections during this transition, anthroposophists often read aloud to their dead relatives for the first few days after death. This is practiced occasionally in all Camphills, but of necessity more frequently in those with elderly populations. The founder of one such community described his community's life as spiritually rich because "this house is saturated with people who've died. . . . It is more than just bricks and mortar and a bit of real estate. . . Where I work in that office, the one in the back there, that's a room where Frances died. Where I'm at the desk, the wheelchair was right at the desk with me where Robert died. Just through that door is where Betty died. Upstairs is where my dad died because we had him for the last few years. . . We are just so lucky." 134 "This whole process of aging," echoed the coworker at Simeon, "is what excites me and I find very interesting-one spent one's whole life learning to become independent and then in the last years one has to learn to become dependent or interdependent. There are so many thresholds to be crossed." ${ }^{35}$

Of the five types of Camphill, elder communities have gone the furthest across the threshold separating Camphill tradition from institutional structures of salaried employment. Since these communities must be licensed as nursing homes, they require nursing and medical professionals, few of whom are available within the network of Camphill coworkers. Yet many of these employed coworkers cherish Camphill precisely because of the ways its communal ethos distinguishes it from mainstream care facilities. And many of those employees today fall in the Gen-X cohort.

Gen Xers are also well represented in the new regions to which Camphill has spread in the past few decades. The fall of the Berlin Wall precipitated an expansion of Camphill into formerly communist countries. The Vidaråsen community in Norway, through the energetic leadership of its founder Margit Engel, launched Pahkla Camphilli Kula in Estonia and Svetlana Village in Russia, in 1991 and 1992 respectively. Seven years later, Inga and Vilnis Neimanis established the first Camphill in their native Latvia after five years of preparatory experiences at Vidaråsen. ${ }^{136}$ They even brought an old Norwegian supermarket with them, reassembling it to serve as the new community's barn!137 Petr Netjek, from the Hogganvik community in Norway, brought Camphill to his native Czech Republic. ${ }^{138}$ Similarly, Hans and Johanna Spalinger marshaled the resources of both Waldorf schools and Camphills in Switzerland to begin the work in Romania early in the 1990s. Within a decade, the work included a day school for 230 special needs children, a regular Waldorf school, two kindergartens, a residential community for thirty children and their caregivers, a small farm, several workshops, a canteen for two hundred people, and its own training course. ${ }^{139}$ Preexisting, initially somewhat clandestine communities in East Germany and Poland also affiliated with Camphill in the 1990s. 
Camphill's work in Asia also began as Gen Xers were coming of age, though older coworkers often played the role of founders. Sadhana Village in India grew out of the friendship between its founder, Vasant Deshpande, and two seasoned Camphillers he met at Camphill Copake, Kumar Mal and Roswitha Imegwu. Kumar and Roswitha were also instrumental in launching Friends of Camphill India in Bangalore. Camphill's presence in Vietnam grew out of the charismatic leadership of Ha Vinh Tho, a cosmopolitan visionary who is also affiliated with Bhutan's Gross National Happiness initiative. Like many pioneers of Camphill in new places, he began his own Camphill journey in an established community, Perceval in Switzerland. After beginning his family there in the late 1970s, he had an opportunity to return to postwar Vietnam in 1982 . He created a foundation, the Eurasia Association, devoted to the creation of schools for children with disabilities, vocational workshops for adults with disabilities, and training programs for social workers. Eurasia then sent seven Vietnamese people to Perceval for the Camphill seminar. Eurasia's schools have educated hundreds of children. But it was not until 2009 that the moment was ripe for the creation of a Camphill-style residential community. That community, Peaceful Bamboo Family, became a full member of the Camphill Movement in 2012. It is primarily a training college, working with young graduates of Eurasia schools to help them find meaningful and income-generating work. Like most Camphills, it has a biodynamic garden and craft workshops, among them lacquer painting and incense making. It also has a tea house as a center of interaction with residents of the neighboring town. ${ }^{140}$

Camphill places in Vietnam, India, and Eastern Europe are still in their pioneering phases. Many have yet to say farewell to their founders or undergo the transition from charismatic leadership that is now a distant memory for other Camphills. Their future development will thus be shaped not only by Gen Xers, but by the more numerous millennials who are currently leading the renewal of Camphill places everywhere.

\section{THE FOURTH GENERATION}

There are two stories that Camphill coworkers of the baby boom generation tell about their millennial counterparts. One is that people born between 1980 and 2000 struggle to make the sort of permanent life commitments that came naturally to people of older generations. The other is that millennials manifest a profound empathy for other people in general, and for persons with intellectual disabilities in particular.

"This is a very special generation," one baby boomer told me when asked about the millennials. "It is hard to know what they want and how they want it." ${ }^{141}$ "We live in a time," echoed another, "when people don't see themselves committing to something for the rest of their lives. People have more than one career.... 
People will say, well, I am willing to commit two years, maybe three years, and after that I am not sure I can continue to do this. So at that level I think Camphill is struggling worldwide."'142

Older Camphillers highlighted the fact that very few millennials have been able to make a genuine commitment to anthroposophy. "Anthroposophy is more or less gone from the younger generation," said one long-term coworker in Norway, even though the younger ones "run the place." "And then of course you have the danger to become like [other social service agencies] because you haven't got this ideal of the image of man." ${ }^{143}$ Russ Pooler gave this point a different accent, suggesting that millennials no longer feel the need to make a stark choice for or against anthroposophy. "People are just much looser. Much more easygoing, much more able to accept more different spiritual paths in a way. I found it really hard to accept one."144

Older coworkers identified a number of factors to explain the millennials' greater emphasis on individual autonomy. One person suggested that millennials are less connected to "the social life" of their communities because they have access to social media and cheap transportation: "They come with a completely different consciousness. Ears full of plugs, and the mobile always out.... There's a bus that goes to the airport, there are very cheap flights. ... If they have a long weekend, off to Vienna or off to Hamburg, and back. In my time, that wasn't possible. You'd have to stay." ${ }^{145}$ Another explained this primarily in terms of a change in parent-child relationships: "In my generation ... the children followed the parents, not the other way around." "146

Many of the millennial Camphillers with whom I spoke agreed with the generalization that they are commitment averse. One told me that he enjoyed the Camphill seminar, but chafed at the intense structure and lack of opportunity to pursue hobbies or "actually create something myself." "Staying here, working six days a week ... is very nice, but I have to explore the world and meet many different people." ${ }^{147}$

Complaints about millennials' lack of commitment are almost invariably balanced with praise for their empathy. "One of the things which I've observed in younger people," said Martin Sturm of Camphill Clanabogan, "is that they have different possibilities to connect with things and people. You may call it empathy." This quality, he went on, makes it possible for millennials to forge a deep connection to anthroposophical practice, even if they find little meaning in anthroposophy as a set of concepts. "And yet you find with some of the older generations it is very much still an intellectualized concept ... upheld through a certain amount of dogma. ${ }^{148}$ Jens-Peter Linde, a Christian Community priest who has spent many decades in Camphill drew a similar contrast. While "the old forms, like Bible Evening ... are becoming rather feeble, there is something taking their place which is what I call empathy. ... That I am able in a selfless way to enter into the being of another person or the being of an association.... I can see that now with the young 
people who come to Camphill. ... They have that in a very beautiful way. They can enter into these difficult children ... and be one with the child and know what to do with it. ... I think it has to do with what Steiner called the reappearance of the Christ in the etheric." ${ }^{149}$

These two observations about millennials are often framed as sweeping generalizations. To the extent that they accent the impact of social media and changes in parenting practice, they parallel observations that are made outside of Camphill. They also reflect the institutionalization of gap-year volunteering as the primary path by which millennials enter Camphill. In stark contrast to the young people who arrived in the 1970s, gap-year volunteers are not motivated by disenchantment with the mainstream worlds of academia and employment. They have yet to experience those worlds at all. Camphill is their first taste of life outside their family home, and they are looking for greater freedom, not for a lifelong commitment. Many have chosen a Camphill that is far from home, for the sake of "seeing the world," but anticipate that they will soon continue their education at a university in their home country. What's more, gap-year volunteers have typically chosen Camphill from a large menu of potential placements. Many opt for Camphill, not because they are attracted to intentional community, but because they are contemplating careers working with persons with learning difficulties. It is not surprising that these young people, many of whom have siblings with disabilities or attended schools alongside classmates with special needs because of "mainstreaming" policies, display strong empathy for the students and villagers they meet. It is also unsurprising that they show less interest in anthroposophy than the new arrivals of the 1970s, many of whom came seeking a spiritual path rather than a career in social work.

Even among millennial coworkers who've been at Camphill for several years, very few belong to the Anthroposophical Society or participate in study groups devoted to Steiner's works. Some openly express disinterest in Steiner; many more appreciate the practical fruits of his work without engaging their spiritual underpinnings. As Newton Dee's Jake Vollrath put it, "I don't really believe in all the spiritual stuff. However I very much appreciate the holistic approach that anthroposophy brings." Steiner's balanced emphasis on thinking, feeling, and willing, for example, informs Camphill's approach to the relationship between "work life, home life, and cultural life" in ways that he finds very helpful. He added that most Camphillers in his generation "pick and choose bits from it than we can identify with," with each individual choosing a unique collection of "bits."150

This pattern creates special challenges for those millennials who are deeply committed to Steiner's spiritual teaching. At one Camphill I visited, I heard stories of tension between two groups of younger coworkers. On one hand there were those-including some who had been raised in Camphill_-who saw Camphill as "full of opportunities" and didn't want to get bogged down in the question of "are we having Bible Evening or not." On the other hand, others were "most concerned 
that what we do has a spiritual basis, that it is based on anthroposophy, based on Karl König, based on the three pillars of the Camphill way of life." "You'd maybe expect," mused my informant, who was from the baby boom generation, that this "would be coming from the older generation," but "quite the reverse." ${ }^{151}$ Indeed, as subsequent interviews revealed, some of the most "conservative" attitudes were held by individuals who were new to anthroposophy. One of them told me that he had come to Camphill at the behest of his future wife, who told him that "it was a kind of paradise." His own experience confirmed this report: "I remember the first day I came there was something happening. You could feel something." Even though he spent his first months "totally in a shock . . standing there in a language I couldn't speak," he appreciated the way he was being transformed by work with people with disabilities and by the lack of a skills-based salary. And yet when I asked him if he was one of the people responsible for Camphill's future, he couldn't give a definitive answer, precisely because he wasn't confident that others of his generation shared his commitment to anthroposophy. "I could say yes, I could say no. Of course, if you live here, if you want to stay, . . . you can be part of decisions.... This is a big problem at the moment. We do not know where we will go." 152

For millennial anthroposophists, the ambivalence of the baby boomer generation can be a source of consternation. One millennial leader, herself born into the Camphill Movement, told me that she had recently joined the Anthroposophical Society. "What I'm finding is that even though the older members may be members of the Anthroposophical Society, but they also are perhaps not comfortable with calling themselves an anthroposophist. . . . I'm a bit confused, what's wrong with being an anthroposophist?" When she attended meetings designed to get people of all generations talking together about anthroposophy, she discovered that "there was only one other person at the meeting who seemed to be in the same sort of place as me. In terms of thinking it was okay to be an anthroposophist." ${ }^{153}$

This difficulty is evident in the life of the inner community. Almost every inner community member I've spoken to, whether they've been part of it for five years or fifty, said that it is less vigorous today than in the past. "Today it doesn't function the same way at all," said Russ Pooler. "It is very loose. . . . It used to be it was a very strong thing. You were either outside or you were inside." ${ }^{154}$ Another told me that when he joined ten years earlier, there was "a very strong inner group," but "then it seemed to take a nose dive, and very little happening. It seemed to die!" At Beaver Run, one person told me that there were thirty or thirty-five long-term coworkers involved in the decision-making Beaver Run Circle, but only seven of these were part of the inner community. ${ }^{156}$ When asked about this, coworker Guy Alma observed that

you can look at living in Camphill as compared to a marriage. You can love someone and cherish someone and raise a family with someone and live with someone with 
single-hearted devotion to someone until the day you die and not put a ring on your finger. . . . For some people the form of marriage is too restrictive. . . For other people, myself included, I wanted to be married. ... We wanted to get married by a priest. ... It is not just a commitment to our social community, it is a commitment to the spiritual world too. ... Community membership is like that.

Guy then acknowledged that although his wife shared his view of marriage, she had made the opposite choice about the inner community. "She has deep feelings about Camphill, it is her life, but she is not going to marry it." He also acknowledged that the "vibrancy" of the inner community is no longer "visible" to many people. "If you didn't know that marriage was available to you as an option, you aren't going to get married." 157

Several people suggested that the inner community's history of secrecy is a liability, because, said Russ Pooler, "the younger people rejected anything of secrecy. It must be all open and transparent." ${ }^{158}$ In several places-including Aberdeen and Botton Village-the inner community has been partly supplanted by "Community Circles" devoted to the study of anthroposophy and open to all Camphillers regardless of whether they are part of the inner community or the Anthroposophical Society. "If we hadn't done what we did within the Circle I think we would be in a far worse place," said one participant, Ruairidh von Stein, at Botton. "[The Circle] is open to noncommunity members. . . . It would be wrong to close it off, because there are many strong people here who are spiritually striving people but they are not necessarily anthroposophists. I still feel the need to be very open to other spiritual streams." 159

Veronika van Duin, herself a long-term Camphiller and the daughter of cofounder Barbara Lipsker, offered a blistering critique of the inner community, which she regarded as increasingly irrelevant to Camphill's future. Though many conversations about the future still take place within the inner community, she sees this as fundamentally wrong because the inner community does not represent all the constituencies within Camphill. Camphill employees might come to one meeting and "never come again," but "have the community members ever gone and said, why don't you come again? ... No. They don't. They say, they are invited to come and they just don't, so we will go on. ... So we are in a real time of transition with Camphill and with anthroposophy."160

In their reluctance to make long-term commitments or to become spiritually connected to anthroposophy, millennial Camphillers are similar to the Gen Xers who preceded them. The difference is that there are many more of them, owing both to gap-year volunteering and to their greater numbers as a generational cohort. Those millennials who break with the generational pattern and stay longterm at Camphill are often motivated by deep networks of connection rather than open-ended spiritual seeking. A young American at Newton Dee, Jake Vollrath, told me that he had grown up near Community Homestead, a Camphill-like 
community in Wisconsin. "I was friends with some of the children.... One of the founding members has been my soccer coach since I was ten. I lived there for just over a year before I came here." Once in Scotland, he discovered that Camphill's BA program, then offered in conjunction with Aberdeen University, fit his learning style well. "As I was doing the BA I needed to show that I could take responsibility for different kinds of things. And I just built it up in a very natural organic way." Gradually, it became clear that Camphill was the right lifestyle for him personally. "I have heard people say, oh, you are so wonderful, you do this work, I could never do this. And that's true to a point, but I could not sit in a bank and cash people's checks. I would find that really difficult. Whereas living in a community with people, I am quite happy to do that." Jake acknowledged that most other people of his generation who come to Camphill discover that it is only "meant for them for the short-term." But that's a strength, not a weakness: "I'm quite happy that it is not a one-size-fits-all." ${ }^{161}$

To outside observers, Jake might seem to be one of the most committed Camphillers of his generation. But he admitted, "I don't feel comfortable making a lifelong commitment," and explained his stance by noting that he is well aware of Newton Dee's history. "Most of the people who have made lifelong commitments to Newton Dee have left," he pointed out. Rather than emulating those predecessors, he prefers to be honest about the fact that "in the back of my head I know that my circumstances could very well change." 162

I heard a more unequivocal commitment from a millennial coworker at Camphill Solborg in Norway. But Steffi Hagedorn also made clear that if circumstances had been different, her path to community might have taken a very different course. She first arrived at Solborg as a nineteen-year-old from Germany with an eight-month commitment. She liked it well enough that she decided to extend her stay. Then she met her husband, and they decided to begin their family in Camphill. Eventually, their desire for more education took them away: Steffi went to another anthroposophically inspired place to complete the social therapy course she had begun at Camphill, then followed her husband to a carpentry training course in Germany. Missing Solborg and Norway, they returned for one year and discovered that the conflicts that had marred their earlier time in community were easing up. "People were getting closer and being honest with each other and sharing more what is going on. . . . To me that was very important." Even so, Camphill's identity as both Christian and anthroposophical created another hurdle. "I am not baptized, I am not Christian I guess, in any sense of the word," Steffi explained. "So it was not, for me, natural to join a Christian community. So at some point I was looking for another kind of community. . . . But then there is no other community that I have found which also works with villagers. And that I love. This is the whole heart to the villages. Without the villagers we wouldn't make it half a year." She also came to see that although anthroposophy "doesn't include all I think is important," it does carry many important values. After thirteen years, 
she can say categorically that she is "definitely a Camphiller" and that she is committed to "protecting" Camphill and "making sure it doesn't lose its values."163

Millennial coworkers noted that their relationship with the previous generation had much to do with the degree of their commitment to Camphill. One told me that, because of the increasingly bureaucratic structure of Camphill, it is difficult for coworkers of his generation to find mentors who are immersed in the daily work of curative education and social therapy. "I have always found relationships with the generation that began in Camphill in the sixties and seventies very important." As a young coworker at Thornbury, he found several such mentors-but most were in managerial positions rather than working directly with the children. He switched to Cherry Orchards "because I felt that Camphill was living here in the everyday," but observed that others of his generation are "seeking mentors of that generation but [unable] to really get down to the life and work with them so directly." 164

A millennial generation leader at Newton Dee told me that the open-hearted attitude of the older generation was one reason she could say that she "definitely" sees herself as one of the people responsible for Camphill's future. "The older generation that I've had a lot of dealings with have been very empowering. I've never felt not allowed to do stuff, or to have ideas. I'm quite choleric so I do argue ... but I've always felt that people listen to me and that they value what I say and they may have another opinion and they will know that my opinion can be changed as well." This experience is different from the time she spent at a nonprofit, in between two stints at Newton Dee, where the people with decision-making power were "really not interested in progress or succession."165

Another factor shaping millennials' willingness to make a long-term commitment to Camphill is retirement policy. Historically, retirement at Camphill was an extension of the larger ethos of economic sharing: just as long-term coworkers forego salaries and trust the community to provide for their needs, so too retirees have assumed that as long as they remain with the community they will be supported. Though many older Camphillers are currently enjoying comfortable retirements under this plan, I've never met a Camphiller under fifty who is willing to extend this level of trust to the community. Some older Camphillers see this as evidence of millennial individualism, but millennial Camphillers are not averse to economic sharing as such. Many say that they would be horrified to receive a salary for the caring work they perform; many say that Camphill's heritage of economic sharing is what attracted them; many have relocated from employmentbased to incomesharing Camphill places. These millennials trust economic sharing as a day-to-day reality, but reject it as an adequate approach to retirement.

The difference here has less to do with generational zeitgeist and more to do with the fact that millennial Camphillers know more about Camphill than their parents' generation did forty years ago. When young coworkers committed to Camphill in the 1970s, they saw that the movement had grown steadily for thirty 
years and was bursting at the seams with young people who were more than capable of providing for the needs of their elders. Young Camphillers today also perceive Camphill as an enduring, resilient movement, but they have seen more ups and downs. They anticipate that some of the Camphill places currently in existence will fail to survive this generational transition. Some of their mentors may be enjoying comfortable retirements, but others are in precarious circumstances because they chose to leave Camphill late in life, or were forced out. Younger Camphillers are aware of the Camphill places that have made the transition from incomesharing to a conventional employment model, leaving their retirees partly or fully in the lurch. And many have seen troubling patterns at more traditional Camphills. One young Camphiller, who was deeply committed to the traditional approach in many respects, told me that shed been horrified to see some Camphill families who lived without salaries but nevertheless "made use of the resources" to maintain a very comfortable lifestyle with minimal engagement in the hard work of "digging their carrots out." When she saw long-term Camphillers leave the movement and find themselves "totally lost, really, in the 'real world," she concluded that "something must be wrong if living in Camphills for such a long time disconnects you from reality." 166

The conditions that make it easy for millennials to stay at Camphill long-term do not yet exist at every Camphill place. If a community is not large enough to include a mutually supportive cohort of millennials, it is not likely to persuade any of its young coworkers to stay on. If coworkers from the baby boomer generation have not consciously stepped out of leadership roles-even without any guarantee that the person who replaces them will have a lifetime commitment-millennials will not experience the challenges and leadership opportunities that give rise to commitment.

The divide between Camphills that have and have not achieved a successful transition to the millennial generation corresponds, in part, to the distinction between the developmental path of "evolving beyond community" and the path of "creative symbiosis." Camphill places that fail to persuade a significant number of millennials to embrace lifesharing as a vocation are perhaps fated to evolve beyond community. Some places, especially in England, have embraced "evolving beyond community" as a matter of principle and do not even try to recruit millennial lifesharers. On the other side, creative symbiosis is a viable option at the places that have already made the transition to millennial leadership. In the past few years, I have visited an increasing number of these communities. Some are large and long-established; others were founded by millennials. Some have leadership teams composed almost entirely of millennial coworkers; others have both Gen X and millennial leadership.

Newton Dee in Scotland is one well-established village that has made a successful generational transition. At the time of my visit in 2016, the chair of Newton Dee's "management group" was someone born in 1977, and five of the twelve members 
of the group were also born after 1970. In Newton Dee's decentralized leadership structure, the management group maintains an overall consciousness of the complex interactions among the many dimensions of the community. It also stands in for an "executive director" in relation to the larger world. Daily life in the larger households is shaped by a circle of about twenty-three "house coordinators"; of this larger group of leaders, only two or three are over fifty.

At Newton Dee, the initiative for generational transition came from the baby boomer leaders who had guided the community from the 1990s onward. Their choice was shaped by the memory of their community's difficult previous tradition, when they needed outside consultants to resolve sharp conflicts over how strictly to maintain traditional Camphill ways. Baby boomers were on both sides of the conflict, and the end result was to solidify the leadership of baby boomers who were relatively open to new ways. Parallel conflicts raged in many other Camphill places in Scotland and England in the 1990s. Often these resulted in the departure of all long-term coworkers, causing the community's charitable board to step in, impose a more conventional top-down management structure, and replace nonsalaried coworkers with paid employees.

By 2012, so many British Camphills had evolved beyond community that this was the dominant ethos in the umbrella group, the Camphill Village Trust, that comprised Newton Dee and ten other villages for adults. Troubled by this development, Newton Dee and the other Scottish village withdrew from the Trust, just as conflict reached the boiling point in several English villages. This withdrawal gave them the opportunity to reinvent themselves, and they did so in a manner intended to insulate Newton Dee from what they perceived as the dire fate of the Camphills in England. They refused to create a singular office of "executive director," creating a large management group instead. They mandated that all the members of that group would be "trust money" coworkers-that is, people who trusted the community to provide their living expenses, rather than earning a formal salary. But they did not reject the idea of salaried coworkers altogether. The majority of Newton Dee's workshops are coordinated by employees, while all the houses are coordinated by unsalaried residential coworkers. The judgment was simply that a healthy balance between the old and the new employment structures could be maintained only if decision-making power was concentrated among people living under the old system.

Almost simultaneously, Newton Dee confronted another challenge: Aberdeen University, which had previously sponsored a program that allowed young coworkers to earn a BA degree while living at Camphill withdrew from that program. The BA program had been central to the community's strategy for generational continuity because it enticed gap-year volunteers in their late teens to stay on for three more years, after which point a significant minority of them were prepared to make an open-ended commitment. About a third of the house coordinators were graduates of the BA program. The potential loss of this stream of young people 
made it urgent for the community to embrace the leadership gifts of the young people it had.

Newton Dee soon became a magnet for young Camphillers who are interested in spirituality and disgusted by the declining emphasis on anthroposophy at other Camphill places, especially those in England. One of the young coworkers I interviewed, for example, told me that he had first learned about anthroposophy in college as a religious studies major and decided that he "wanted to live it, not just read about it." His quest took him to a school for children with special needs that was inspired by anthroposophy but not part of the Camphill Movement. The most inspiring person he met there was a house manager who had lived in Camphill for ten years, and her example convinced him that "Camphill provided that real living anthroposophy." But the first Camphill place where he worked, in England, was rapidly shedding its traditions, and several others openly refused to accept families with children - a clear sign that they were ambivalent about the Camphill tradition of treating coworker families as full members of the community. Newton Dee emerged as his first choice because of its fidelity to incomesharing and lifesharing, and because its proximity to other Camphill places ensured that he would also be embedded in a lively anthroposophical community. ${ }^{167}$

Interestingly, this particular Camphiller worried that even at Newton Dee, the younger generation was not holding tightly enough to the spiritual core of anthroposophy, even as they celebrated the communal practices that derived from it. Conventional organizations, he explained, have hierarchical structures because power has a natural "tendency to shift into [ever] smaller groups." Without deliberate practices that enable people to see themselves as spiritual beings rather than as bearers of power, it is almost impossible to maintain "a horizontal or circular way of working." ${ }^{168}$ On the other hand, he was married to someone whose feelings about anthroposophy were similar to those of the other coworkers. She cherished the example of anthroposophists whose "spiritual striving" allowed them to "live their lives in a way that totally shines into other people's lives," but she'd met others who led her to conclude that "as soon as you start following it as a dogma, it becomes a bit cult-like."169

Another Camphill whose young leaders have embraced the path of creative symbiosis has not yet experienced a generational transition. Heartbeet Lifesharing was founded in 2000 by Hannah Schwartz and Jonathan Gilbert, who were then in their early twenties, and formally accepted as a Camphill community several years later. Hannah and Jonathan's choice not to offer their gifts to an existing Camphill community took a certain measure of fortitude, for by 2000 many Camphill places were already worried about generational transition. They would have been thrilled to recruit someone like Hannah, who had grown up at Camphill Village Kimberton Hills and attended the seminar for young coworkers at Camphill Copake, and whose charismatic gifts were beginning to be recognized throughout the movement. But as a twenty-four-year-old, Hannah did not 
experience existing Camphills as "super breathable" for people with new ideas. As the mother of an African-American child, she was eager to expose her daughter to racially diverse worshipping communities, rather than attending chapel services at Camphill every week. At the time, that idea was not well received-in part, she speculated years later, because she was not quite comfortable "coming up against" older Camphillers who had known her since childhood and whom she still perceived as "giants." By starting her own community, she reasoned, she could experiment freely and adopt only those Camphill traditions that still made sense. Initially, that experimental ethos meant that even the question of whether Heartbeet would be a Camphill was left undecided. Within a decade, Heartbeet decided that it would, emphatically, be part of Camphill; by that point, a more mature Hannah recognized that "there is tons of room for creativity."170

Located in the Northeast Kingdom of rural Vermont, Heartbeet has almost as much land as Newton Dee but only about a third as many people and a more limited menu of agricultural enterprises and craft workshops. The community hall was completed recently; prior to that, the felting, fiber arts, and papermaking workshops gathered in residential houses. Its leadership structure, similarly, is relatively uncomplicated: only in the past few years has the community succeeded in moving decision making away from the charismatic authority of the founders to the community as a whole. That community is composed almost entirely of people under fifty, most of them in their twenties and thirties. The only exceptions are the older relatives of the founders, some of whom have spent time at Heartbeet in a kind of semiretirement. At Heartbeet the persons with special support needs are just as youthful as the coworkers with whom they share community life-a natural consequence of the age of the community. At Newton Dee, by contrast, there are dozens of elderly persons with disabilities who have lived their entire adult lives in community, limiting the number of spaces available for younger persons with disabilities. Thus, while Heartbeet can be described as a "youthful community," Newton Dee might better be described as an aging community with youthful leadership.

One way in which Heartbeet has fostered commitment among millennial Camphillers is by hosting youth conferences. The first was in 2002, and it has held at least a dozen since then. Hannah Schwartz credits one of her sisters with inspiring the first conference. As a young adult member of a branch of the Anthroposophical Society filled with older adults, she was desperate to find spiritual colleagues her own age. Thus, the first few conferences were intended for young adults connected with all aspects of anthroposophy, not just Camphill. Later conferences were intended more narrowly for younger Camphillers.

In organizing these conferences, the Heartbeeters were mindful of the tradition of anthroposophical youth conferences. The early years of the Anthroposophical Society were marked by tension between an older generation interested in studying Steiner's ideas and younger people who wanted to put them into practice. The founders of Camphill first met as an anthroposophical youth group in Vienna. 
And many baby boomer Camphillers, including Hannah's parents, solidified their own connection to anthroposophy at national or international gatherings. Hannah has drawn freely from her parents' friendship circle in recruiting speakers at Heartbeet youth conferences.

These conferences create a space where young Camphillers can meet generational peers who share their depth of commitment to the movement, and also find mentors among the older generations. Ordinarily, older Camphillers are diffident about their traditions because they know that many gap-year volunteers have no interest in long-term commitment. This leaves potential long-termers adrift, unclear about the connections between Camphill's spiritual roots and its present reality. At Heartbeet's conferences, the diffidence disappears: sessions might feature a spiritual interpretation of correspondences between key events in world history and in Camphill history, or a detailed presentation of the economic theories underlying Camphill practices of economic sharing. These heady lectures are punctuated with artistic workshops and hilarious interventions by two clowns, Kristin Crowley and Angie Foster, who ask one another befuddled questions about the anthroposophical jargon they've just heard. The implicit message is clear: all the resources of Camphill tradition are at the disposal of the new generation, who are free to receive them with absolute seriousness or deep humor.

Heartbeet's blend of youthful energy and traditional Camphill values has made it especially suited for creative symbiosis. Much of the community's work happens in coordination with likeminded businesses in the larger community, among them Pete's Greens community-supported farm, High Mowing Organic Seeds, and the Cellars at Jasper Hill, which produces aged cheeses. These businesses grew up alongside Heartbeet, with all the founders participating in an entrepreneurial support group where they learned management skills and shared challenges. It was natural for them to become work sites for some of Heartbeet's disabled residents who wanted more connection to the wider community. Several marriages also link Heartbeet to its community partners, who are becoming as invested in Camphill's future as the Heartbeeters themselves.

A third successful transition has occurred in a less likely place. Unlike Newton Dee, Camphill Solborg in Norway is not a large village with so many young coworkers that is easy to find a romantic partner in community. It is not accessible to other anthroposophical initiatives or to a city with a lively youth culture. And, unlike Heartbeet, it was not founded by millennials. Solborg was founded in 1977, and for most of its history it was led by baby boomers who had been mentored by Margrit Engel, the guiding figure in Camphill Norway for most of its history. Still, in 2016 nine of the twelve coworkers on Solborg's village council were in their thirties or forties, and its villagers were also disproportionately in that age group. Among the leading coworkers, five or six lived at the community for about fifteen years. "That group has become the group that carries the village Solborg into the future," one of them told me. "The older generation that was carrying it before, they 
became pensionists or have left, so it is up to us basically." As a result, many things about the community are different. Whereas their predecessors had participated actively in anthroposophical study groups, such activities do not shape Solborg's direction in an especially conscious way anymore. ${ }^{171}$

What has taken anthroposophy's place, explained Steffi Hagedorn, is a deeper sense of emotional, interpersonal commitment. "We are much more bonded to the place and to each other than we were before," she stressed. "Before maybe it was more idealistic - 'oh, we are all anthroposophists, we should go there'-but ... there was not so much loyalty. Now I feel that there is a lot of loyalty between people." This loyalty has been hard won. For several years there was so much conflict that virtually the entire coworker group turned over every few years. Finally, "there was a group saying, we don't want to leave, we want to stay, and we need to solve conflicts." Around that time, Camphillers across Norway became interested in a system of conflict resolution called "Zen coaching." Though this has no connection to anthroposophy, Camphillers saw enough affinity that they were willing to give it a try. "It is about listening with the heart to each other and repeating what the other has been saying." Once this took hold, even some of the people who had left the community began coming back. ${ }^{172}$

Even before the generational transition, the community had committed to broadly shared leadership, with a "village council" making most major decisions. The new leaders cherish this tradition. They are also committed to extending it to include villagers more fully. "We are much more aware of every villager having their own voice and rights and trying to help them to make adult decisions," explained Steffi Hagedorn. "We shouldn't force them to do things. Before, we wouldn't physically force somebody but there would be houseparents who would just decide that a villager would stop smoking. Now that would be unheard of." This change, she added, reflects Solborg's increasing openness to the larger society, as the Norwegian authorities insist on self-determination for persons with disabilities. ${ }^{173}$

Amid the diversities between Newton Dee, Heartbeet, and Solborg, it is possible to identify a few common features. Communities that have achieved a generational transition in leadership tend to be home to a significant cohort of millennial coworkers who are raising families alongside one another. They are hospitable to the formation of romantic partnerships and flexible with couples in which only one partner is fully committed to Camphill. Millennials find it easier to commit to raising children in Camphill if they know they will not be the only ones doing so, and often they relocate from one Camphill to another in order to find this cohort of peers. Paradoxically, the fact that many Camphills have deliberately chosen to evolve beyond community by limiting incomesharing and lifesharing has made it easier for millennials who cherish those practices to become concentrated in a smaller number of more traditional Camphill places.

Second, many of these communities have at least a few former staff kids among their millennial cohort. These individuals help bridge the generations. Hannah 
Schwartz, for example, was not merely raised in the Camphill Movement. She is the daughter of prominent Camphillers who are familiar to virtually all long-term Camphillers in North America, and many around the world. Her mother, Sherry Wildfeuer, still lives at Kimberton Hills and edits the Stella Natura biodynamic planting calendar that is published by that community. Her father, David Schwartz, has lived in many different Camphill places, including Heartbeet, and David's partner has chaired the Camphill Association of North America. When established Camphillers look at the new things happening at Heartbeet, they see continuity as well as change, and reassuring evidence that they must have been doing something right, since their children want to carry it forward. Much the same can be said about Newton Dee. One member of the management group is married to the daughter of one of the most influential leaders of the baby boomer generation. Other former staff kids serve as residential coworkers or employed staff.

Third, communities that have made a successful transition are deliberate about telling the story of their transition. This story may involve the deliberate stepping back of baby boomer leaders. Or it may be the story of the community's founding by members of the millennial generation who aspired to re-create Camphill life for a new age. In either case, there is a clear understanding that successful generational transition doesn't just happen-it must be consciously chosen.

Fourth and finally, communities that have embraced the millennial generation's leadership are often characterized by what I call "creative traditionalism." They promote the leadership of a new generation while zealously maintaining core Camphill values. Attitudes about Camphill tradition, moreover, do not correlate predictably with one's generational identity. Older Camphillers are not presumed to be conservative custodians of tradition, and the young are not expected to be rebellious innovators. Rather, the young are forging their own relationship with tradition, modifying its details in order to preserve its essence. Typically, they are fierce defenders of the traditional Camphill practices of lifesharing and incomesharing, and sometimes sharp critics of other Camphill places that have curtailed those practices. But they are adamant that these practices must continually be adapted and renewed in relation to changing circumstances. Often, these communities have experienced a period of intense conflict in which Camphill traditions were severely questioned, and then reaffirmed in modified form. They might, for example, practice a form of lifesharing in which families have more private space (including small kitchens) than was the case previously. Or they may pay salaries to all their coworkers, but use a pay scale in which differences are very small and based on longevity rather than the specific tasks performed by the coworker. Though both Heartbeet and Newton Dee cherish the ideal of economic sharing, both have embraced couples in which one spouse wants to live Camphill 100 percent and the other wants to maintain a professional identity through employment "outside." In some cases, the spouse who wants more professional autonomy was raised in Camphill and doesn't want to live just like their parents, while the 
other came to Camphill as a young adult. These communities also have governance structures that concentrate power in the hands of traditional coworkers as opposed to villagers, employees, or board members, but also distribute power fairly broadly within the traditional coworker group.

Heartbeet's employment and retirement policies exemplify the creative traditionalism that many millennial Camphillers seek. At the beginning of each year, each coworker or coworker family prepares a budget of their personal needs. If the community is able to meet those needs, it reports that amount to the IRS as the coworker's income and makes the appropriate payment into the Social Security system. This ensures that these coworkers, unlike their Camphill predecessors, will be entitled to Social Security benefits as retirees, whether or not they remain in Camphill. Heartbeet, like most Camphills today, also promises a specified amount of "leaving money", commensurate with years of service, to any coworker who leaves the community. In effect, savings and retirement are individualized, reflecting the real possibility that the individual will not remain with Camphill for life, while present-day budgets remain communal.

Another aspect of creative traditionalism, evident especially at Heartbeet, is the comfortable embrace of spiritual and therapeutic practices not rooted in anthroposophy. Heartbeet defines itself as a "sober community", honoring the presence of many people with personal or familial experiences of alcoholism, and many of its members participate in weekly therapy groups in the nearby town. Many have been trained in Marshall Rosenberg's "Nonviolent Communication" or in the "Holistic Approach to NeuroDevelopment and Learning Efficiency." Such practices might be perceived as dilutions of Camphill tradition if they occurred elsewhere, but it is hard to perceive them as such when they are promoted by Hannah Schwartz, who is as deeply committed to the esoteric details of anthroposophy as anyone in her generation.

At even the most successful places, there are unresolved questions about the place of anthroposophy in Camphill's future. At the root of these questions is a generational difference. For baby boomers, lifesharing, incomesharing, and anthroposophy were generally experienced as a package. For Gen Xers and millennials, there are significant numbers of people who are deeply invested in lifesharing and incomesharing, but uninterested in anthroposophy. The consequence is a twofold stepping back. People without a personal connection to anthroposophy may hesitate to take on leadership (especially beyond their local community) because they sense that Camphill's thriving depends on its connection to anthroposophy; meanwhile, people who do have a personal connection to anthroposophy hesitate because they are conscious of their minority status. Another consequence is that the inner community is not even able to knit together the traditional coworker group, much less expand its scope.

Even, and perhaps especially, at places with strong cohorts of lifesharing millennial coworkers, I also observed employees and villagers who had significant 
leadership gifts and a genuine commitment to Camphill ideals. In some but not all cases, these people had not been invited to shape the future of their particular Camphill. In virtually all cases, they had not been invited to shape the future of the Camphill Movement. This is the most important issue facing Camphill right now, and I am not aware of any Camphill place that has fully faced it. There simply is no inclusive body able to include employees and villagers in the future-shaping work that was historically performed by the inner community. To understand why this matters, we must consider differences of role as well as differences of generations. Villagers, employees, coworkers, and other role-based groups are the vital organs within the Camphill organism. 


\section{Camphill Constituencies}

Camphillers do not like to put people into categories. If you ask Camphillers about the distinctions that I will be discussing in this chapter-between villagers and coworkers, between employed coworkers and those who practice incomesharing and lifesharing, between those who reside full-time in Camphill and those who only spend their daytime hours there-you are likely to get into an argument. "Our dear friends, you might call them villagers," replied coworker Ruairidh von Stein when I asked him about the villager experience in Camphill, "I don't want to call them any names really, I hate titling, but anyway, they are our teachers." While the overcoming of categories is a sincere aspiration, it has yet to be fully realized in Camphill. Some Camphillers pay to be in Camphill and receive special support; some are paid to be there and to provide special support; some neither pay nor are paid. Often, the first group are called "villagers," the second "employees," and the third "coworkers," though there is much variation in terminology. This economic distinction coincides with a host of other distinctions about how people are invited to join the community, what roles they are encouraged or allowed to play, and how they exercise leadership. Sometimes, a subset of Camphillers is conflated with "the Camphill community" as a whole. My best guess is that Camphill can only transcend these distinctions by reflecting more explicitly about how they function currently. I offer this chapter as a contribution to that reflection.

Camphill's aspiration to overcome categorical thinking is entangled with the work of generational transition discussed in the previous chapter. As that chapter made clear, many Camphillers are thinking only or primarily about coworkers when they talk about generational differences. On the surface, that is where the generational problem lies: it is the long-term coworker group, not the other constituencies, that is still disproportionately composed of baby boomers. Yet this way of framing the problem ignores the radical diversification of Camphill constituencies that has occurred alongside the transition from baby boomers to Gen Xers and millennials. A successful generational transition will require not only the 
recruitment of more lifesharers from the millennial generation. It will also require the empowerment of Gen X and millennial villagers and employees who are already present in Camphill in large numbers. It might involve an expansion of leadership structures comparable to the transformation that occurred during the last years of Karl König's life. Just as he created structures that honored the new geographical diversity of Camphill, so today the movement needs to recognize the diversity of roles. The inner community, for example, might be renewed if it stopped assuming that a true "Camphiller" is a nondisabled adult with a spiritual connection to anthroposophy who lives full-time at Camphill and does not receive a salary. (Currently the inner community includes many members who do not fully fit this description because they have moved out of Camphill, but almost all of them have fit it sometime in the past.) Camphills are home to persons with disabilities who have lived there for decades and who serve as memory keepers and informal mentors to newcomers. Their mentoring gifts could be more deliberately cultivated. Likewise, many employees were drawn to Camphill because they resonated with its ideals, yet they are rarely asked to help hand Camphill to future generations.

In the most dynamic Camphill places today, the sense of communal belonging extends, not only to employees and to persons with special support needs, but to the community's neighbors. Lehenhof's neighbors cherish it for its bakery and its grocery store; the Bridge's for its café and walking paths. Camphill Callan in Ireland has played host to classes of young adults exploring environmentally sustainable, traditional building techniques. Parents and friends of Camphill Copake sponsor an array of fundraising cultural events. And Heartbeet has been part of Hardwick, Vermont's culinary renaissance. These places are full of people with a stake in Camphill's future.

Every generational transition involves a broadening of the definition of community. In Camphill's first transition, a founding circle with a common refugee experience took the brave step of opening their "inner community" to include anyone who shared their anthroposophical ideal of living in community with persons with disabilities. That generation extended the circle to include baby boomers with a much wider range of life experiences and ways of connecting to anthroposophy. But today, one assumption made in both of those transitions - that primary authority for transmitting Camphill's traditions from generation to generation belongs to lifesharing coworkers who are rooted in anthroposophy-has proven to be far too narrow. The Camphill Movement today includes hundreds of shortterm volunteers, nonresidential employees, extended families of residents, and nonprofit board members - to say nothing of the persons with disabilities themselves. A successful generational transition will empower all these people to fulfill Camphill's founding mission of bringing "renewal" to society as a whole-though perhaps it would be better to say that a deeper commitment to social renewal among Camphillers will ensure a successful transition. 


\section{STUDENTS AND VILLAGERS}

Persons with intellectual disabilities-sometimes referred to as "students" at Camphill schools and training colleges, and as "villagers" at villages, town communities, and elder communities-anchor Camphill life. Though they are not the outright majority of Camphillers, they are a strong plurality - at least, if one treats "young coworkers" with a planned departure date as a distinct category from "lifesharing coworkers" who have made an open-ended commitment. Many villagers have been part of Camphill for decades. If a Camphill place has a resident who has been a part of the community since its founding, that resident is almost certain to be an adult with special support needs. Students and villagers carry Camphill's memories, including memories of who is responsible for which household task or of who lived in the community ten or twenty years previously. The daily and seasonal rhythms of Camphill life are designed to help anchor the experience of persons with special needs: each day is broken into multiple short work shifts, with common break times and "rest hours," and festivals are celebrated in multisensory ways that remind everyone of the changing rhythms of nature. At most festivals and weekly religious rituals, villagers and students are the majority of participants. Many others are present primarily to help the villagers and students participate fully.

When Camphill places introduce themselves to the public, they often lead with the experience of villagers and students, putting the ideal of intentional community in a subordinate position. The website for Camphill Scotland asserts that "Camphill provides sector leading care services for people with learning disabilities and other support needs." ${ }^{2}$ Newton Dee's website says that they "offer a home, meaningful work and opportunities for personal development to adults with learning disabilities and other special needs." 3 And the Camphill Association of North America declares that "Camphill is an international movement of intentional communities designed to meet the needs of children, youth, and adults with developmental disabilities through a combination of community life, the arts and work on the land." 4

Yet not all Camphills describe themselves this way, and few are comfortable with the implication that Camphill is a place where people without disabilities work in service to people with disabilities. The mission statement of Camphill School Aberdeen, for example, leads with community and avoids any distinction based on ability: "To create a community where children and adults feel a sense of belonging, support and personal growth. A place where there is an inclusive, lifelong learning culture with an integrated approach to health, education and care." ${ }^{5}$ Camphill Village Kimberton Hills's statement also accents intentional community: "Camphill Village Kimberton Hills is a dynamic farming, gardening, and handcrafting intentional community that includes adults with developmental disabilities."

I do not mean to suggest that some Camphills understand themselves primarily as service providers for persons with disabilities and others view themselves as intentional communities. Most Camphills describe themselves in both ways, 
and there is no consistent correlation between a particular Camphill's language of self-description and its degree of adherence to the communal practices of incomesharing and lifesharing. Rather, the creative tension between identity as a service provider and as an intentional community defines Camphill precisely because it cannot be definitively resolved. Occasionally, Camphillers claim that Camphill began as an intentional community movement committed to social renewal, that it took up the work of curative education for accidental reasons, and that it could and perhaps should take up different tasks in the future. Such claims are unpersuasive because they drive a wedge between an imagined Camphill essence and the movement's actual history. They also betray the thousands of persons with disabilities who have devoted their whole lives to building up Camphill. Conversely, to describe Camphill as a service provider accountable only to the care needs of persons with disabilities is also a betrayal-for such persons have a right to contribute to society as well as a "need" to be "served." In an age that rejects the "institutionalization" of persons with disabilities, too much emphasis on Camphill's service dimension can, paradoxically, jeopardize the funding it receives from government agencies that are committed to providing persons with nonrestrictive, "community-based" care. As Veronika van Duin put it, "our biggest disaster has been to put the handicapped person into the center. They should have been in the periphery, not in the sense of exclusion, but because of them we've been able to make community. The moment we focus on them, we can't build community." 7

Because only about 15 percent of Camphill places today are schools, it can be easy to forget that Camphill's early work focused exclusively on care for children with special needs. This had a profound consequence for the history of the movement: although Camphill has always been built around the needs and experiences of persons with learning difficulties, in the early years it was only the nondisabled coworkers who made an open-ended commitment to be part of an ongoing Camphill "community." As things turned out, the coworkers were mistaken to imagine that they were the only ones who would spend their entire lifetimes in Camphill. Several of the first students went on to participate in village life. Yet the assumption that terms like "Camphiller" apply primarily to the nondisabled segment of the community and only secondarily to those with intellectual disabilities persisted in subtle and unintended ways. The widely read biographical compendia titled The Builders of Camphill and The Lives of Camphill, for example, do not feature the stories of any persons with intellectual disabilities. ${ }^{8}$ As these books make clear, the anthroposophical spirituality and shared refugee experience of the founders and early coworkers contributed as much to the emerging sense of "Camphillness" as did the presence of persons with intellectual disabilities. This blending of formative factors sets Camphill apart from the otherwise similar L'Arche movement, which has never sponsored schools and always placed the experiences of adults with intellectual disabilities at the center of its identity. In L'Arche, 
for example, persons with intellectual disabilities are called "core members," other people are called "assistants," and assistants rarely spend their whole lives with L'Arche. Camphill's hybrid sense of identity has sometimes created tension with social care authorities, who are rarely interested in any aspect of Camphill life except insofar as it contributes to the well-being of persons with intellectual disabilities. Yet the same hybridity lends credence to Camphill's claim not to be a network of institutions for social care, but rather an intentional community movement in which people of all abilities are equally valued, and all learn together what a nondisabling society might be like.

It is unlikely that a communal movement based on schools for children with special needs could arise today, at least not in the places where Camphill originated. The early Camphill participated in a cultural shift that helped the parents of children with intellectual disabilities recognize the human dignity of their children, and as a consequence most parents now want to keep those children at home with them. Society is now better, though far from perfect, at providing parents and mainstream schools with the tools they need to help children of all abilities flourish. The founding of Camphill schools slowed in the 1970 and virtually halted in the 1980s, with a few exceptions in postcommunist countries. Some Camphill schools have evolved into villages, others have endured in part by specializing in work with children with extraordinarily complex needs (usually those with both mental illness and intellectual disability) and in part by incorporating evergrowing numbers of day students. Because most of these schools have reduced their enrollments to accommodate more complex needs, the total number of students with disabilities who are part of the Camphill Movement is almost surely less today than forty years ago.

The children who first came to Camphill were a diverse and impressive bunch. Because disability was defined differently in 1939, many had diagnoses-such as epilepsy - that are no longer considered forms of intellectual disability. Some were referred to Camphill because of juvenile delinquency or because their parents were simply unable to manage aspects of their behavior. Most had been scarred by past experiences of rejection or failure, and many were surprised to learn just how much they could contribute to their new community.

The first student, Peter Bergel, was ten years old when he arrived at Kirkton House on May 10, 1939. His parents, like many of the founders, were German Jews who had escaped the Holocaust. The United States had accepted Bergel's parents as refugees but, bizarrely, forced them to leave their child behind in Europe. Anke Weihs recalled him as "barely able to speak, incessantly restless, his mind bent obsessionally on looking for cigarette cartons ... a thoroughly disconcerting new element in our lives." Thirty-six years later, he was a mainstay of the Botton Village community. The next student was not a child at all, but a thirty-six-year-old epileptic "whose convulsions were so violent and elemental that they could be heard from one end of the house to the other." Alistair Macmillan also arrived early on, 
cementing a partnership between his family and Camphill that ensured the survival and expansion of the movement.

Another early student, Athol Henry Byrne, born in 1937, arrived at Camphill School in 1952. He quickly developed strong connections to Camphill's founders and early leaders, among them Thomas Weihs and Hartmut von Jeetze, who instilled in him a "deep and lasting love for farming and for the land." After completing school, Byrne worked on several farms outside Camphill, then was recruited to help start the farm at the brand-new Camphill in Northern Ireland, Glencraig. He enjoyed this work so much that he asked to join the pioneering group for the other two villages in Northern Ireland, Mourne Grange and Clanabogan. In each case, he helped instill the Camphill ethos into employed or coworker farmers. Karl König's son described him as "a wonderful worker" with "great strength, and a deep love for the animals," and "by far the best hand-milker I have come across." Jens-Peter Linde, his cofarmer at Clanabogan, said that he never would have been able to start that farm without Byrne, both because of his vigor at digging postholes and stirring biodynamic preparations, and because "I learned from him how to be at peace with a cow: the head slightly angled, resting against her flank." Henry was also committed to the anthroposophical liturgy of the Christian Community. This gave him an opportunity to stretch himself: though he was ordinarily "not a man of many words," he learned the role of the right-hand priest's assistant, who "has to give the right answers." He could still perform this task perfectly on his deathbed, at age sixty-three. ${ }^{10}$

Byrne's pioneering efforts at Mourne Grange were complemented by those of David Austin Reid, an early student at Glencraig whose parents helped establish that community. After joining the founding group at Mourne Grange, Reid "informed himself of all the new buildings that were built" and was "especially conscious of safety aspects, constantly reminding us of the dangers of tractors and builders' equipment." Because of his safety consciousness, he was chosen as the community's "deputy fire officer," a role that allowed him to befriend local firefighters and thus deepen the new village's ties to its neighbors. He was also fond of taking his bicycle out into the neighborhood-a practice that one friend said was facilitated by his "very active guardian angel."

Other early students had more tragic destinies. In the early years of Glencraig, the community struggled greatly to gain the trust of their neighbors-some of whom spread rumors that they were Russian spies-and rejoiced when they attracted their first student. Robert was just five years old and fond of singing "Daisy, Daisy, give me your answer do," and soon four other students followed in his path. But little Robert died in his sleep just five months later, and it was "only through the tremendous help we received from close friends and his understanding Mother" that the fledgling community retained the trust of the local authorities. The Hermanus School in South Africa suffered a virtually identical early tragedy, when a boy named Robert died just before their first Advent Children's Service. ${ }^{12}$ 
When I asked coworkers to talk about the place of villagers in Camphill's future, they were unanimous in stressing the ways they make a deep experience of community possible for everyone in Camphill. "Adults with disabilities are the glue of the community,"13 said one; others identified them as "vital"14 and "the reasona necessity for this world." ${ }^{15}$ "They were always our teachers," explained another person. "They were the ones who gave us love. We aren't very good at loving each other as coworkers. ... It is the faithfulness that they have carried, for years and years we have worked alongside each other. If we were to be just a coworker community we wouldn't be able to survive." ${ }^{16}$ Even those, such as Veronika van Duin, who insisted that "Camphill's task was [never] the handicapped person, it was the human being," were quick to add that "the person with special needs has this amazing gift of equalizing everyone. You meet someone who has special needs and you forget yourself and you become a human being." ${ }^{17}$ At times these testimonies were tinged with romanticism, yet they clearly reflected a genuine experience: many coworkers struggle to imagine how a community would knit itself together emotionally if everyone had similar intellectual abilities. "Maybe they have cognitive learning disabilities, but we have learning disabilities in our emotions and in many things," explained music therapist Javier Gonzalez Roa after leading a class that I personally found more challenging than did some of the villagers in the room. "Normal people have problems to see other people. The guys with learning disabilities, at the moment they see you, they know how you are. ... They don't want you hiding yourself. ... So for me to work with them is so easy, because I just need to be myself." ${ }^{18}$ Another person pointed out that a diversity of abilities ensures that people do things together, because not everyone can simply do those things for themselves. When villagers go away for holiday, he observed, the rhythms disappeared, "because why should we all eat together sometimes if it is only coworkers? They can just make their own bread when they want, or cook something quick, do something else."19

Several Camphill places have taken deliberate steps to underscore their conviction that there is no essential distinction between persons with and without disabilities. Camphill Holywood, in Northern Ireland, has a single handbook for all community members, rather than a coworker handbook and a resident handbook. ${ }^{20}$ Newton Dee pairs every community participant, regardless of category, with a designated supervisor who helps them contribute to the well-being of the community. Newcomers are assigned supervisors upon arrival, and after about a year they have an opportunity to request someone specific if they prefer. "Generally," Jake Vollrath told me, "people will choose somebody because they want somebody who is going to reflect things back to them and actually challenge them to become better at their job." ${ }^{21}$

Most Camphillers are acutely aware that the language used to describe persons with special support needs can reinforce patterns of stigma and hierarchy, even when that language is intended to lower boundaries. Camphillers began using 
the term villager, for example, to avoid defining individuals primarily in terms of their clinical diagnoses. In theory, villager could include everyone who resides in a Camphill village. In practice, a villager is almost invariably someone entitled to receive special support and care, while a coworker is expected to provide that support and care. These terms are used even in some town communities that do not regard themselves as "villages" at all! Troubled by the way villager had become "just an alternative euphemism for talking about people with mental handicaps," the Loch Arthur village community repudiated the term soon after their founding in 1984. "To talk of 'villagers," Fran Clay explained, "is to fool oneself that one has found a solution that manages not to stereotype or subtly degrade the group you speak of-by now it is as much of a label as any other term." For the sake of transparency, they chose to stick with "people with handicaps" on those occasions when a term was necessary, freely admitting that they had not fully solved the problem. ${ }^{22}$ In my observation, most communities that refrain from using the term villagers wind up with another single-word euphemism: I have heard both friends and guys used in ways that signal that only persons with disabilities are included. When asked recently what terms they preferred, a group of persons with special support needs at Scottish Camphills opted for resident, tenant, student, member, day person, worker, day student, and human being, but none chose villager. ${ }^{23}$

Many Camphillers point to Rudolf Steiner's teachings on social therapy as an important source for this egalitarian ethos. "To me the core of social therapy is that we do not address the handicap," explained coworker Steffi Hagedorn at Camphill Solborg, "but we address the perfect core behind, the perfect human being that is behind there. ... When I talk to villagers I try to meet [them] as equals, in small glimpses." She tries to maintain a "humble attitude" that says "maybe they are handicapped, maybe they don't talk so well or walk so well, maybe they need a lot of help, but what can I learn? What do they teach me about the joy of life, about being present ... about accepting people?” This approach, she concluded, sets Camphill apart not only from mainstream social care but even from "other anthroposophic places where people come and work eight hours and go home."24

Writing in 1976, Peter Roth connected the full inclusion of persons with disabilities to another aspect of anthroposophy. "It is a prejudice of our intellectual times," he wrote, "to think that we, the 'normal' ones, need another culturalspiritual life than the handicapped adults, the villagers." This prejudice, he suggested, was a consequence of mainstream Christianity's rejection of the threefold view of humanity (as body, soul, and spirit) that Rudolf Steiner had restored. By affirming humanity's spiritual nature, anthroposophy could create a form of adult education that was not narrowly intellectual and thus truly inclusive. ${ }^{25}$

At some Camphill places, persons with learning difficulties have raised their own voices about practices that reinforce boundaries based on ability. Victor Alvez, who lived at Camphill Soltane for two years before his untimely death in 2001, began reversing roles at his entrance interview, when he brought a videocamera 
to tape his conversation with community founder Cornelius Pietzner. He also brought "the heart of an activist" to his participation in the community's morning meetings. "Have you noticed," he asked pointedly on one occasion, "that no one really listens when the companions [i.e., persons with disabilities] speak during our morning meetings the way they listen to the coworkers. We need to change that." Victor also contributed "a deep connection to Buddhism" to Camphill life, and frequently offered wise counsel to new coworkers struggling to connect with Camphill's spiritual practices. ${ }^{26}$

Many defenders of incomesharing and lifesharing are convinced that these are what make the full inclusion of persons with special support needs possible. The "community spirit" of Camphill, Jonas Hellbrandt stressed to me, is to "create a vocation for everybody in the world rather than [just] the so-called well-functioning normal people." Villagers should "be painters together with us, be farmers together with us, be musicians together with us." This requires equality, and "one of the most obvious ways of continuing to be equal is not having a financial difference between us." Similarly, when people live together, there is no difference in how much time they have to contribute to the community. The community can extend its "therapy" to everyone who lives there. ${ }^{27}$

At Camphill Vidaråsen, one community leader made this point with reference to a recent episode in that community's history, when the community rejected (in part) a consultant's proposal that they eliminate lifesharing. As soon as you start employing people "who are qualified in care, in social work," he explained, then the focus of the village shifts to the villagers' needs "rather than the villagers being able to contribute on an equal footing with everybody else [toward building] up the village together." It is a "contradiction in terms" to make the villagers the purpose of the community, "because the whole point of the Camphill community as far as I had been aware is that one creates a valid, vital environment for a range of different kinds of people into which those with special needs can be included." Indeed, the only reason Vidaråsen wasn't shut down with the other institutions in the 1980 os was that it made a convincing case that it was "a kind of inside-out integration." The parents of Vidaråsen's villagers rejected the consultant's recommendation because they did not want their children to be "treated as patients" but "as fellow citizens, as colleagues and friends." ${ }^{28}$

Nevertheless, there are few Camphill places today where everyone simply lives together on a basis of financial equality. In addition to the increasing numbers of nonresidential employees, many Camphills now include nonresidential students or "day program participants" - that is, adults who participate in Camphill workshops during the day but reside with family or in non-Camphill group homes. This is a change that has mostly occurred since the turn of the twenty-first century. When I visited Beaver Run in 2014, one teacher recalled that twenty years previously they had had just one day student. A decade later there were ten, then thirty-six day students alongside fifty-two residential students in 2014. Most of 
the people I spoke to identified this as the most significant recent change in the life of the community, which now felt like two distinct communities, one present on weekdays and another on weekends and evenings. Previously the whole community had taken a rest day on Thursdays, then observed a fairly intense Saturday culminating in Bible evening; now it followed the conventional five-day work week, even though this rhythm was difficult for many of the children. It became more difficult for the community to celebrate the traditional Camphill festivals, which often fell on days when nonresidential students were not present. Previously, class teachers had operated with much autonomy and freedom; now they followed detailed "individualized education plans" for each student. Because the students had increasingly complex needs, many of them worked one-on-one with a young coworker for much of the day, disrupting the therapeutic power of the classroom community. ${ }^{29}$ And most visibly, the nonresidential students shattered the boundary that had once separated Beaver Run from the larger society. "You have twenty-five school buses coming in every morning," observed Guy Alma. "The outside world flows through the place, even visually, when you see that yellow line of buses going up the hill."30

I felt a similar influx of influences from the larger society at Camphill Tiphereth, which hosts dozens of day participants in addition to the residents of its three houses. Many of these people participate in Tiphereth's community composting program, which collects yard waste and food scraps from homes and businesses in southern Edinburgh, then trucks them up to a former quarry high on a hill above the city. The composters are continually on the go in and out of the city, which remains visible to them as they work. Other day program participants engage in crafts and therapeutic workshops in the large building that also hosts Tiphereth's offices. Javier Gonzalez Roa stressed that the day program participants derive significant benefits from spending their days in a community setting that is somewhat detached from the rest of society. "This lovely Camphill world is really good for their soul," because it gives them a break from "the TV and all these distractions." ${ }^{31}$

Even as some Camphills open themselves to nonresidential students and adults with special needs, there are other Camphills where persons with learning difficulties constitute the entirety of the residential community. England's Camphill Village Trust, for example, has phased out lifesharing in most of its communities. Though many coworkers (and others) perceive this as the end of intentional community and a return to the old institutional model of care, the fact is that the villagers are still doing the hard work of creating life together. I got a brief glimpse of this new model of Camphill community when I visited the Croft, a small town community located an hour's drive from Botton Village. After attending a church service in which several persons with disabilities played leading roles, I stopped off at one of the residences. It was much messier than the typical Camphill home, and it seemed to have a more chaotic schedule, as some residents were eating breakfast individually rather than as a group. The materials displayed 
on the walls, and the slogans on people's T-shirts, suggested that there was less anthroposophical influence and more exposure to popular culture than in other Camphills. But what I noticed most strongly was the sense of ownership exhibited by the people who lived there: they were clearly proud to show a visitor the home that they had created. They also had stronger verbal skills and more capacity to perform personal care tasks than many of the profoundly impaired adults who live in traditional Camphill villages.

My perception of the Croft was echoed by a staffperson at Sólheimar, an anthroposophical community for people with special needs founded just prior to Camphill. For many years, all of Sólheimar's nondisabled staff lived offsite, and today they live in the village but in separate homes from the persons with disabilities. Coworkers, he said, "tend to forget, we are so self-centered, we think we are carrying the community, but at the end of the day it is the people with disabilities who are-they have been here $24 / 7$ for decades." Still, he cautioned against generalizing too much from this experience. Many of Sólheimar's villagers had come as children and lived there for as many as sixty years, building up "a certain kind of culture." Now they are being replaced by a younger generation whose "complexity of ... disabilities is much greater than in previous years." ${ }^{32}$

The increasingly profound impairments of many villagers create a challenge (and an opportunity) for all Camphills, regardless of their stance on incomesharing and lifesharing. The shift is a consequence of social care policy, which discourages the placement of persons in large or even midsized residential settings if they have any capacity to live autonomously. The relatively "high-functioning" students and villagers who built up Camphill in the early years would likely not be allowed to live there today, unless they had the wealth to pay Camphill's fees without government support. While many social workers assume that the "right" villager for Camphill is a person with multiple and complex needs, many coworkers think it is someone who is able to make an active contribution to village life. "There is a certain group of people with special needs that we are fit for as a community," observed one coworker. "People who can work in workshops. People who don't need very specialistic psychological care." And it "may be a challenge in the future to find [such] villagers." ${ }_{33}$

Of all the Camphills I have visited, Camphill Glencraig in Northern Ireland had probably gone the furthest down the path of redefining itself as a place for persons with extraordinarily complex needs. The change "hasn't always been something which has been agreed by the rest of the community," explained Vincent Reynolds, but it did honor a timeworn Camphill principle: "This is what was said by Dr. König in the beginning, that the aim is to meet the needs." Again and again, the social care authorities came to Glencraig with children with "very challenging behavior" who had already been excluded from other schools for special needs children. The arrival of such children provoked a backlash from some coworkers, both because they lacked the training needed to be genuinely helpful and because 
one-on-one care for individual children did not fit with their image of community life. "You have to be really engaged with these young people. You have to be following them around all the time. It can also be very demanding when you are just observing someone and nothing appears to happen." Still, the reality was that if they refused to accept such children they wouldn't have a school at all. ${ }^{34}$ So the community has brought in employees able to meet the children's needs. At the time of my visit in 2013, they were setting up a new house to accommodate a single girl who required the support of multiple employed caregivers twenty-four hours a day. The community was just beginning to imagine how they might give the girl a genuine sense of community connection.

At many Camphills, the challenges associated with the increasingly complex needs of new villagers are coupled with those associated with the aging of villagers who arrived decades ago. "There seem to be more physical limitations," reported the coworker Jake Vollrath at Newton Dee. Previously, "we did quite hard physical work, and now the work isn't quite as rigorous physically, but we have to find new ways to provide meaningful work for everyone." 35

The fact that social care authorities are often willing to place only profoundly impaired persons at Camphill highlights one of the most vexing boundaries within the movement: persons with and without intellectual disabilities join Camphill communities through vastly different processes. Those with disabilities can join Camphill only if someone-usually the government, sometimes a family member - can pay a hefty participation fee. Those without disabilities can join for free, if they can convince the community that they are capable of supporting persons with disabilities (or, in some cases, that they have agricultural, medical, or artistic skills needed by the community). There is no path in for people whose support needs are so minimal that they are not eligible for government benefits, but whose disabilities or other life challenges limit their capacity to provide therapeutic support to others. Yet such persons, who would have no other role except to participate in the life of the community, could bring a great deal to Camphill. I had the privilege of witnessing this during my first summer at Camphill Village Minnesota. A very mildly disabled young man who had grown up as a staff kid at Camphill Minnesota, then attended a Camphill training college as a student, was back for the summer to reconnect with his parents and Minnesota friends. Like me, he was assigned regular workshifts, but none of the therapeutic tasks ordinarily given to coworkers. He quickly became my beacon for Camphill life, someone who entered into each task with enthusiastic joy and attention to the emotional dynamics of everyone else present.

The legacy of Camphill's beginnings, in which the enduring "community" consisted of the nondisabled coworkers who taught in the school, still lingers in many ways. It is evident in the movement's newsletters, which only occasionally publish the words of individuals with learning difficulties. Virtually every issue of the Camphill Correspondence, the newsletter since 1975, contains at least one coworker obituary, and often three or more articles devoted to the life of a single notable 
coworker. The lives of villagers are also remembered, but only sporadically, and almost never with more than a single article.

Many Camphills also maintain boundaries based on disabilities through their decision-making structures. Few of the nonprofit boards that provide legal governance for Camphill places include either villagers or other persons with intellectual disabilities (such as leaders in national self-advocacy organizations). It is common for Camphill places to have "management teams" composed entirely of coworkers, or with a mix of coworkers and employees but no persons with intellectual disabilities. Most day-to-day decisions are made by committees with specific mandates, such as assigning individual work shifts or ensuring that each house community is functioning smoothly. Since these committees operate by consensus, they could easily make room for members who are able to understand some of their decisions but not all. Yet they rarely include persons with special support needs, with the frequent exception of committees whose task is to prepare for festival celebrations. In many Camphill places, the primary venue for villager participation in decision making is the "village meeting" - a gathering of all residents in which any person can bring a concern or request to the community. These meetings have succeeded at giving all villagers the chance to shape the places where they live. But maintaining that success is a delicate balance. If coworkers fail to attend, then concerns expressed by villagers may not be heard by the people best able to address them, but if too many coworkers participate, their voices may drown out the less confident voices of the villagers. ${ }^{36}$

I have received a variety of answers when I have asked Camphill coworkers and board members about the absence of villagers in decision-making roles. Placing a villager on a decision-making committee "can sometimes be a bit false," one person pointed out, because "it doesn't actually mean that they are being included in the decision-making process." ${ }^{77}$ Some have pointed out that nonverbal and other profoundly impaired villagers would not be able to play such roles, and that it would not be fair to give additional power to the others. That's a valid concern but not insurmountable, especially in a consensus system where the coworkers would doubtless take extra care to represent the needs of villagers who were unable to participate on their own behalf. Some have said that a small number of villagers can and do participate in decision making, but that this is simply not the best gift that most have to offer the community. That's probably true, and compared to many communal movements Camphill benefits from having a large number of people who cherish community but are not obsessed with governance. Still, much the same could be said of coworkers: many came to Camphill in order to pursue a particular craft or therapeutic vocation, but actually spend much of their time in decision-making committees out of a sense of duty to the community. Why shouldn't the same duty apply to persons with disabilities?

Many coworkers responded to such interview questions by agreeing emphatically with my underlying concern. "I would like to see them in much more prominent roles," replied Ruairidh von Stein. "I don't think it is right to make 
decisions on behalf of residents, villagers. . . They are part of our shared future." ${ }^{8}$ Camphill, one person told me, is "more and more, waking up and wanting to take into account the issue of civil rights" for persons with intellectual disabilities. She pointed out that the practice of intentional community is inherently complex, because every community member gives up some of their individual rights when they accept the shared rhythms of the community. But too often Camphill fails to do the hard work needed to maximize individual control over such decisions as dietary preferences. The challenge, she said, is "how to help the people we are supporting to actually begin to develop the muscle to understand their rights and to exercise them meaningfully." ${ }^{9}$ Her colleague added that this is especially important because so many villagers have acquiesced to their parents' preference that they be in Camphill rather than making a fully volitional choice. And so their community has worked with an organization called the Council for Quality and Leadership to learn a practice of "reliable interviewing," so as to ask each villager, of whatever ability, to make an authentic choice each year about whether to continue in Camphill..$^{\circ}$ Other Camphill places have organized "self-advocacy" groups for villagers, sometimes giving them responsibility for recreational spaces within the village. The results can be unsettling for persons devoted to Camphill tradition: In one village tour, I was shown a "self-advocacy" room that included a bank of computers, a large-screen television, and other amenities previously shunned by Camphill. Such experiences might be a sign that Camphill is not doing enough to recruit villagers who truly want the alternative lifestyle of intentional community, or they might indicate that villagers truly cherish Camphill life but don't think it is quite as antithetical to the social mainstream as coworkers have assumed. Either way, they should not be ignored.

Often, this means taking decision making to the level of each individual. A coworker at Camphill Heartbeet told me that they actually do have a villager on their board of directors, and have since the beginning. But she acknowledged that they are not represented on the community's working groups, partly because "severe anxiety" is one of the impairments for many of the people in the community. "My job is to help create simple, meaningful rhythms where their anxiety does not have to be triggered." That means that instead of inviting people onto decision-making committees, she needs to be willing to enter into one-on-one agreements that are truly binding on her. "If a friend wants me not to use certain language in a conversation with them, then I won't use that language." She concluded that "inclusion means that I am not trying to peg someone else's needs into what I think needs should be." ${ }^{41}$

One important marker of the inclusive ethos is the recognition of villagers' sexual identities and needs. Increasingly, Camphills actively seek to facilitate safe and appropriate sexual expression for everyone who lives in Camphill. At Heartbeet, one young couple with learning difficulties was guided through the process of dating, engagement, and marriage, and now maintain a semi-independent apartment 
as a married couple within the community. Vidaråsen, working with outside specialists in sexuality, has set up support groups for men, women, and couples. They've also worked to identify "borderline problematic sexual behavior," before it creates the sort of problem that would lead to the expulsion of an individual from the community. The truth is that sexual abuse is part of the history of more than one Camphill, and it sometimes involves perpetrators with intellectual disabilities and victims who are persons with intellectual disabilities or staff children. So, even as Camphills have tried to be more affirming of sexuality, they have also enacted safeguarding practices that can sharpen divides within communities, such as the policy that coworker families with young children do not share bathrooms or other intimate living spaces with villagers. ${ }^{42}$

A final way in which villagers are distinguished from other Camphillers has to do with the practice of anthroposophy, and of religious services inspired by anthroposophy. An important anthroposophical principle is that "freedom" is the guiding principle in the spiritual life. Most Camphills are careful to ensure that no person, coworker or villager, is required to attend religious services. Yet in practice many villagers do attend, and most young coworkers do not, and newcomers to the community easily discern that this is the unspoken expectation. Even villagers who identify strongly with their Jewish heritage participate in religious services with strong Christian content, and are not necessarily offered the transportation or other support they might need to participate in Jewish rituals. At the same time, villagers who manifest a profound devotion to the public practice of anthroposophy are rarely invited to encounter its more esoteric expression by, for example, joining the Camphill inner community or attending an anthroposophical study group. Many Camphill places offer the "Festival of Offering," a ritual that is designed to be led by specially trained laypeople known as "service holders." Villagers are seldom asked to be service holders, even in places where they are the most faithful participants in the service. It is more common for villagers to serve as assistants to Christian Community priests who preside at the Act of Consecration of Man, but that can happen only in places with resident or visiting priests. Of course, it is possible that some villagers are participating in the esoteric work of anthroposophy in ways that are too subtle for me to observe. As one long-time coworker told me, "saying the Our Father every night is certainly esoteric work." 43

Camphill's categorical distinctions come closest to dissolving in its festival life. In keeping with the indications of Rudolf Steiner, Camphill celebrates seasonal festivals in ways that blend Christian tradition with nature spirituality. Christmas, Easter, St. John's, and Michaelmas-days that correspond roughly to the solstices and equinoxes - are the most important festivals. A Christmas celebration may include meditative reflections on each of the "Twelve Holy Nights," while St. John's features a massive bonfire. Michaelmas uses the story of Michael's defeat of the dragon to reflect on ways of overcoming evil. Camphillers spend weeks preparing for each festival, often practicing musical or dramatic performances or involving 
people of all abilities in the creation of works of art, such as a giant paper lantern in the form of a dragon.

Camphill's festival culture has helped it include people of diverse abilities in conferences that bring people together on a regional or international basis. Even when a conference coincides with a decision-making meeting that is not fully inclusive, villagers and students are often invited to come along. In many conferences, participants are divided into artistic groups (devoted to singing, drama, eurythmy, sculpture, poetry, and other forms) that meet once or twice a day in order to develop a performance or exhibit to be shared with the entire gathering. As early as 1976, the German villages designed a conference especially for villagers. Each day began with a lecture with such thematic titles as "Sleeping and Waking" or "Doing and Perceiving," followed by a conversation in which participants practiced listening deeply to one another. As Regine Blockhuys wrote: "The villagers contributed in a wonderful way out of their personal experience, or often out of the sphere of their work or sometimes quite from above, giving the talk a direction which made it a deep and moving experience for all. Some spoke more often at the beginning and learned to hold back, others surprised us by speaking exactly to the point reached in the talk after they had been silent for long." Participants also had an opportunity to display products created in their workshops to their new friends, and each evening they rehearsed a play together. Many of them praised the experience in terms that underscored its value: "I never experienced such a lovely thing as this conference!" 44

The German villagers conference may have inspired a similar gathering at Blair Drummond in Scotland in August 1976. Once again, its structure mirrored that of conferences for coworkers, with serious discussions intermingled with prayers, singing, and artistic activities. The first discussion was about work and money, explained observer Erika Opitz, and participants affirmed the centrality of meaningful work to their sense of identity. "I know it has to be done.' 'It is essential.' 'It is done for others and with others.' 'I feel well when I have done well." Later, the participants reflected on their motives for living in Camphill stressing that "there I can be myself"; that in community "I can help others, care for others"; and that community life had helped them break out of isolation and enjoy being with others. Writing in the Camphill newsletter, one participant observed that "It was very fruitful that we could all talk together without the distinction of villager and co-worker, all equal, feeling that we discussed what it means to live in Camphill." 45

I experienced the same spirit at a Whitsun celebration that the German Camphills hosted for the international movement in 2018. This was designed as an inclusive festival in which villagers, coworkers, employees, family members, board members, and neighbors could participate simply as human beings, without regard to their diverse roles. From the beginning, the planning process reached beyond Camphill, and many of the sessions were held at Lautenbach, a village community that is rooted in anthroposophy but not formally part of the Camphill 
Movement. Each evening featured a public lecture, while the daytime was devoted to artistic pursuits. The whole thing culminated in a parade led by a brass band and featuring massive, newly made puppets and banners displaying inspirational quotes in many languages. Participants of all abilities performed in a series of plays, and a troupe of clowns who were newly equipped with red noses interrupted the proceedings with bumbling hilarity. It was a foretaste of the social renewal that Camphill aspires to bring to the entire world.

Ultimately, the inclusion and empowerment of students and villagers is what will best equip Camphill to plant seeds of social renewal beyond its own boundaries. "Every year," Camphill founder Thomas Weihs announced in his 1975 annual report on Camphill School, "Camphill sends out about one hundred emissaries. About a third of them are the handicapped and disturbed youngsters who have been educated, helped, and guided to grow up into freedom and dignity" ${ }^{46}$ In the same year, a person at Newton Dee, Margarete von Freeden, observed that "our Villagers have a great number of friends in Bieldside and around. On a fine Saturday or Sunday a stream of 'Newton Dee-ers' can be seen walking to and from Aberdeen. In shops or neighbours' front gardens you can be asked with deep concern about matters you thought only the inhabitants of Newton Dee knew of." ${ }^{47}$ This dynamic has intensified as the larger society has become inclusive of persons with disabilities and as social care bureaucracies have expanded, enabling students and villagers to introduce their social workers or volunteer "buddies" into contact with Camphill. If the modern quest for authentic community is to move from the cultural fringe to the center, perhaps it will be persons with intellectual disabilities who make it happen.

\section{LIFESHARING COWORKERS}

Students and villagers represent one of the great continuities in Camphill. They have always been central to Camphill life, even though the exact meaning of that centrality has shifted over time. Lifesharing coworkers, by contrast, represent a great change. When Camphill began, it was possible to use the term Camphill community when one was referring only to these people, but today they are probably the smallest of the major constituencies within Camphill.

With the phrase lifesharing coworkers, I refer to people who live full-time in Camphill communities, do not have intellectual disabilities or comparable care needs, have an open-ended commitment to living in Camphill for the foreseeable future, and do not receive salaries or wages commensurate with the care work they perform. This definition is deliberately vague, for there is no sharp boundary between lifesharing coworkers and other groups of Camphillers. In the United States and Scotland, lifesharing coworkers often also practice incomesharing, albeit with modifications designed to give them more freedom to leave Camphill at midcareer or in retirement. In continental Europe and Canada, it is more common 
for lifesharers to receive formal salaries designed on egalitarian principles, with the most experienced coworkers receiving only slightly more pay than newcomers. Some Camphill places make a strong distinction between lifesharers who live in the community and employees who do not; others insist that there is no distinction, because everyone shares their life in one way or another.

Lifesharing coworkers may also be referred to as "vocational coworkers," because they have chosen Camphill as their vocation, at least for a significant portion of their adulthood. Those who share incomes may be called "trust money coworkers," referring to the system in which coworkers "trust" the community to provide for their needs. Typically, each individual or family identifies needs for the coming year, and then the coworker group discerns whether they are able to accommodate all requests. Unlike participants in some service communities, trust money coworkers do not necessarily live near the poverty level. They occupy beautiful homes, eat organic and biodynamic food, send their children to Waldorf or other private schools, and-at some communities-take international vacations on a yearly basis. The guiding value is not sacrifice or even simplicity; it is that human labor should not be reduced to a commodity. From the Camphill perspective, all human beings have a right to offer their best gifts freely to other people, and to have their needs met regardless of the economic value of their gifts.

Many people regard the declining number of lifesharing coworkers as Camphill's greatest challenge. "I think our biggest [challenge] is bringing young people here so they can help carry this into the future," Leslie Fish told me. "Because the large majority of us are heading down the retirement road soon. And we don't have a good core of young people who are going to carry this in the future." ${ }^{88}$ In the 1970s, one baby boomer recalled, "many people came to Camphill around the world ... and met something very strongly and committed themselves to that work. I don't see that happening so much anymore." ${ }^{49}$ Another coworker, Christoph Hanni, echoed that thirty years ago Camphill School Aberdeen "was the generator of coworkers," a place where young people could begin their life in Camphill and then move on to greater responsibility in a newer Camphill place. "That kind of kept the Camphill Movement going"-and now it "has totally gone."50

Some view the decline in lifesharing coworkers as tantamount to Camphill's demise. This is the lament of one person who migrated as a "refugee" from Holland to Scotland when the former country abandoned both incomesharing and a horizontal decision-making structure, only to see similar changes in British Camphills. "If you employ more and more people who don't really know what it is about and who are not interested in learning more about it," Marjan Sikkel said, "then it just disappears because we get older and we die and it is gone." "It "I'm not sure it qualifies for being a Camphill anymore," complained one coworker of a place where he had lived for sixteen years before it had abandoned lifesharing..$^{52}$ At a more traditional Camphill in Norway, coworker Steffi Hagedorn echoed this sentiment: "social therapy is all about creating a social organism between us.... It 
is not me being the therapist and the other one being the patient, but it is a social organism that is therapeutic for everybody involved. And how you do that when half of you are paid by the minute and half actually live there?" 53

Most Camphillers who worry that the decline in lifesharing might spell the end of the movement see this as a gradual process. One explained that with the shift from lifesharing to conventional employment, it is tempting to see persons with special needs as "service recipients." This in turn creates a "wrong footing" for intentional community, which is all about "interacting and being shaped by other people ... including people with disabilities. They are not a separate stream, they are also people who help me, annoy me, inspire me, make me a better person, and I also can help them because I can see things that they are weak in and I can support them. So it is that true interaction with those disabled people, that's the kind of schooling path of Camphill." ${ }^{54}$ Guy Alma of Beaver Run acknowledged that he still feels a sense of "Camphill-ness" in places run entirely by nonresidential employees, but wonders if "that tangible presence will be there one or two generations hence." The crucial factor underlying Camphill identity for coworkers, he explained, is the experience of "living with individuals with developmental disabilities day in and day out.... That is the seed which everything else grows from." Currently, many of the employed managers did have that experience before moving out of Camphill, and so "the matrix is still there for that grace to touch down," but when that ceases to be the case, "I think you'll have echoes in the architecture and the rest of it, but I don't think that presence will be tangibly there anymore." ${ }_{55}$

A number of factors contribute to the decline in lifesharing coworkers. In Germany, Switzerland, and France, incomesharing is technically illegal: all people are guaranteed a salary commensurate with the job tasks they perform. Because this change was implemented early in Camphill's history, when the movement was otherwise thriving, some of those communities were able to preserve the incomesharing spirit by creating "social funds" in which coworkers voluntarily pooled their salaries. But many of these systems declined over the years. "They found," said one observer, "that there was an unfortunately close relationship between the amount you were putting in freely and the amount you were taking out." 56

In Great Britain, the employment laws are more flexible when it comes to longterm volunteers, but many Camphill boards have nevertheless concluded that incomesharing and lifesharing are not legally feasible. Incomesharing makes it more difficult to be transparent about how government funds are spent; lifesharing complicates the work of safeguarding villagers from abuse. Early in the twentyfirst century the Camphill Village Trust, which operates most villages and town communities in England, began transitioning individual communities to a model based on conventional employment; subsequently they imposed this as a universal policy. Other communities, most recently Ballytobin in Ireland, have been forced to abandon lifesharing by social care authorities in the wake of reports of abuse. "The traditional Camphill model of coworkers running a community has almost 
completely disappeared" in England and Wales, one community founder told me in 2013. "You could count on the fingers of one hand in this country communities which are substantially run by coworkers." 57

The ethos of lifesharing remains strong in several parts of the Camphill world, among them several of the Scottish communities, most of the communities in the United States, the entirety of Norway's Camphill Village Trust, and many German communities. Yet even these places find it more and more difficult to recruit lifesharers with an open-ended commitment, or to persuade young coworkers to take on a more permanent commitment.

One reason is the increasing bureaucratization of social care. Coworkers who long simply to share their lives often resent having to fill out detailed reports on the adults with whom they live, and to comply with household regulations designed for large institutions. For instance, I have seen Camphill kitchens in which the posted regulations indicate that people cooking rice must repeatedly check its temperature to ensure that it complies with a government-mandated standard. "It becomes so difficult to have a normal lifesharing," lamented Tobias Pedersen, a former coworker who was an employee at the time of our interview and has since taken a position with the Biodynamic Agriculture Association of Ireland. "People are exhausted. They can't do it. They get burnout." As an employee, Tobias still had to comply with bureaucratic regulations, but these were no longer coupled with the very different burden of being emotionally present twenty-four hours a day. "I can hopefully recharge my batteries and have a life outside of Camphill." Still, "it is definitely a sadness. There is something missing as a result." ${ }^{8} 8$ Another Camphiller said that when he tried to compose a job description for a lifesharing house coordinator, simply listing all the tasks that they are legally required to perform, others in the community rebelled. "Nobody liked it. They were terrified by it. . . . They said nobody's ever going to apply for that." 59

As the numbers of lifesharing coworkers have declined, some Camphills have sought to protect the ethos of lifesharing by restricting certain roles, such as management and house coordination, to lifesharers. "We have made a conscious choice," explained Jake Vollrath of Newton Dee, "that we want to make sure that the intentional community members who are living in are the ones who are really managing Newton Dee. . . . Because when you live in the community, your ... awareness of the needs of the whole community can be quite drastically different. And we want to be able to carry that ourselves." This commitment has led to some compromises in the community's egalitarianism. The circle of house coordinators, for example, has no overarching manager because they are all lifesharers, while the workshop coordinators, most of whom are employees, report to an individual manager, who is a lifesharer. ${ }^{60}$ Similarly, instead of appointing an executive director, Beaver Run vests management authority in a "Beaver Run Circle" that is open only to lifesharers with at least three years of community experience, an open-ended commitment to remaining at Beaver Run, and a personal connection 
to anthroposophy. People involved in the Beaver Run Circle consistently testified that its restriction has helped the community maintain a coherent vision. ${ }^{61}$ Beaver Run has also mandated that its many employees report to supervisors who are themselves coworkers-and who have been properly trained for their supervisory role. "The attempt is to penetrate every area of life with anthroposophy," Guy Alma explained. "And you can only really do that if you have people who are seasoned coworkers from the village who are trying to work out of that orientation ... who at the same time actually have some mastery of the more prosaic day-to-day things." ${ }^{2}$

The paradoxical consequence of policies that restrict management tasks to lifesharers is that lifesharers have less time for the daily activities-cooking and cleaning, participating in workshops, offering therapies, and joining in festivals and cultural events - that constitute lifesharing. A typical house coordinator, one coworker told me, might have weekly one-on-one supervision meetings with each young coworker in their house, weekly meetings with the other house coordinators, biweekly meetings with the central leadership body, and ad hoc meetings called to respond to specific challenges. "I would say about half the time maybe could be in all those different kinds of meetings." ${ }^{63}$ In many cases, lifesharers have taken time away from community life to earn degrees or certificates that will qualify them to serve as managers who interact with social care or educational authorities. When Beaver Run needed a new director of programs for its school, for example, they identified a lifesharing coworker who was a great fit for the role but not yet formally qualified. They paid for him to pursue a master's degree in special education and hired a special education director from a nearby school system to perform the role on an interim basis. This added to the workload of another lifesharer, who was called upon to supervise the interim employee. Ultimately, the process was a great success, but it represented a radical cultural shift from the days in which just one person handled all of Beaver Run's interactions with the educational authorities. ${ }^{64}$

Most Camphills have evolved economic structures that make small compromises with employment law and the social care establishment, while preserving the ethos of lifesharing. Many of these compromises seek to guarantee the economic security of lifesharing coworkers who leave Camphill, both by offering "leaving money" commensurate with years of service and by paying in to government pension plans. These policies recognize that many coworkers have a long-term but not lifelong commitment. They reassure care authorities who wish to know exactly how their funds will be spent, and coworkers who are not confident that Camphill itself is committed to them. Another compromise is the creation of "economic fellowships" for Camphill coworkers who receive salaries as mandated by government but want to separate their work from their income. At Solborg and other Norwegian Camphills, for example, brand-new coworkers receive housing, food, a small stipend (known as "pocket money") and a guaranteed level of leaving money. After they've stayed for a certain period, they are invited to join both the 
village council (the governing body) and an "economic fellowship" that provides them with additional funds based on need. Members gather every two or three weeks to share both their monetary needs and their needs for time away from the community. "That group can decide amongst themselves if they want to give that money for something you need or give that time to do something, " explained one participant. ${ }^{65}$ Even so, some members of the community long for a deeper sense of economic community. As Steffi Hagedorn explained, "We share our budgets, we share our needs, and we share the money, but we do not yet share our accounts. We don't actually tell each other how we have used the money."66

When I spoke to younger lifesharing coworkers (as distinct from "young coworkers" with a short-term commitment), most articulated a balanced set of desires. On the one hand, they had chosen Camphill because of the way it separated work from income: "We all do work because it is needed," said Steffi Hagedorn, "and we do what we can, we give all we have, and then our needs will be covered." If Camphill were just a job, they said, they might choose a different job. ${ }^{67}$ On the other hand, they stressed that the role needs to evolve in order to retain its appeal and viability. While previous generations of coworkers often felt they "worked for free" and with a lifetime commitment, said Jonas Hellbrandt at Newton Dee, "the traditional coworker model for a generation like mine is more a recognition that we work under a very different salary structure, a needs-based structure. I don't think we as a generation feel we work for free." What's more, it involves a commitment to "this lifestyle for the foreseeable future," but not necessarily for a lifetime. ${ }^{68}$

This balanced approach, coupled with the influx of "refugees" from Camphill places that have abandoned lifesharing, has stabilized the constituency of lifesharing coworkers at many Camphill places. Worldwide, hundreds of millennials are living the Camphill coworker life in much the same manner as previous generations. Yet there is, to my knowledge, no Camphill place that is dominated by lifesharing coworkers to the degree that virtually all Camphills were dominated a generation ago. I have not visited any Camphill place in which all workshop leaders were residential coworkers. Whether the group of lifesharing coworkers is stable or shrinking, they must shape Camphill's future in partnership with others.

\section{YOUNG COWORKERS}

Unlike lifesharing coworkers, so-called "young coworkers" have remained a stable component of the Camphill organism. Like other coworkers, "young coworkers" are people without intellectual disabilities who live full-time in Camphill communities, participate in household life, workshops, festivals, and therapies alongside other Camphillers, have their economic needs met, and receive no formal salaries. The key difference is that they commit to only a fixed term of participation in Camphill. The most common pattern is for young coworkers to join Camphill for a year of service, often a "gap year" between high school and university, or a 
postcollege volunteer year. Most young coworkers choose Camphill places outside their home countries. At least since the 1960s, Camphill communities have advertised through nonanthroposophical networks designed to promote international volunteering, and these networks have brought volunteers whose primary motivation may be to see the world or to explore the possibility of a career working with persons with special support needs. Other young coworkers come from anthroposophical families or are graduates of Waldorf schools; these people may have chosen Camphill because they want to deepen their connection to anthroposophy or simply because the anthroposophical milieu is comfortable for them.

Two of the young coworkers I met at Glencraig illustrate the range of paths these young people take to Camphill. One said that her process was "quite spontaneous." She had wanted to go abroad, and so she applied to a Red Cross project in England. When that fell through, a friend of her mother's whose children had attended Waldorf schools introduced her to another young woman who had done a gap year at Glencraig. She applied in late spring, got approved, then had to get approval from a German organization so that it would be an "official" volunteer year. When she arrived in Glencraig, she was surprised by "how big it was and also how beautiful. I really liked the sea." She had a great experience, made lots of friends, and got "brilliant references" from the teachers with whom she worked. Yet she never seriously considered a long-term commitment to Camphill, which she described as a "bit like a bubble": beautiful, good for the villagers, but socially isolated and demanding for long-term coworkers. ${ }^{69}$ The other young coworker had deeper Camphill roots: his father was a Waldorf teacher, his severely epileptic sister had been a student in a Camphill community for eight or nine years, and he himself had attended Waldorf schools his entire life. He also came to Glencraig intending to stay for one year, but when he heard about the opportunity to pursue a multiyear seminar, he embraced it..$^{\circ}$

Both of these young people were German, as were the majority of young coworkers until quite recently. Until recently, German law mandated military service for all men but allowed them to substitute domestic and international volunteering. This created a culture of gap-year volunteering that applied equally to women, who were not subject to the conscription law, and has persisted since conscription was placed in abeyance in 2011. Since 2011 the distribution of nationalities among young coworkers has diversified, though Germans are still the largest group. The United States does not have a vigorous culture of gap-year volunteering, but recent college graduates may come to Camphill through Americorps or similar programs. Some U.S. Camphills, recognizing that college graduates are more mature and more likely to make a long-term commitment to Camphill, actively discourage volunteers who are under twenty years old. Interest in Waldorf education and other anthroposophical initiatives has increased in China and South Korea, inspiring young people from those nations to come to Camphill in hopes of gaining the skills they will need to plant new initiatives back at home. Restrictive immigration 
laws in North America and Europe make it difficult for Camphills to obtain visas for volunteers from Africa and other developing nations, though they regularly receive promising applications from these places.

While many Camphills use the term young coworker exclusively for people in their first year at Camphill, I am also including so-called seminarists and BA students who participate in multiyear training programs. Camphill School Aberdeen inaugurated its first "seminar in curative education" in 1949, and it served as a model for the seminars in curative education (at Camphill schools) or social therapy (at Camphill villages) offered by most of the larger Camphill places ever since. These immersive and experiential seminars are structured similarly to the training courses that prepare people for other vocations connected to anthroposophy, such as Waldorf teaching, biodynamic farming, eurythmy, or the Christian Community priesthood. They begin with a "foundation year" in which students explore Rudolf Steiner's core ideas through reading, discussion, and artistic experience, then turn to more specialized training in subsequent years. Often, the foundation-year seminar includes all coworkers in their first year at Camphill, making it easy for those who initially made a single-year commitment to stay on for the entire seminar. Initially, the content of Camphill seminars was thoroughly anthroposophical; it functioned both to initiate participants into a personal identification with anthroposophy and to prepare them for the therapeutic tasks of Camphill life. Over the years, the approach has become more ideologically diverse, albeit to widely varying degrees.

Around the turn of the twenty-first century, several Camphills created structures to allow their young coworkers to receive formal academic credit for the experiential learning they do at Camphill. This idea was broached as early as 1976, but not realized at that time..$^{71}$ Recognizing that many young people cherish their time at Camphill but are unwilling to forego the benefits of university education (or to resist their parents' expectations for them), the designers of Camphill-based bachelor of arts degrees hope that these programs will make it easier for young coworkers to extend their initial year to four, and then perhaps to ongoing commitment as lifesharing coworkers. They also recognize that regulatory bodies often insist that caregivers hold vocational qualifications from accredited academic bodies. Of course, people with degrees in curative education or social therapy may have opportunities to take the skills they have learned at Camphill and obtain professional employment in other settings. But many Camphill leaders welcome this possibility. No one should stay at Camphill merely because they lack other options, and those who take their skills elsewhere are empowered to infuse some of Camphill's values into mainstream institutions.

Camphill School Aberdeen established its first BA program in the 1990s. Camphill Scotland hired multiple consultants to foster dialogue between longtime coworkers and external social workers, and the idea of a community-based curriculum was honed through this dialogue. ${ }^{72}$ The first educational partner was 
Northern College, a center for teacher training that was soon thereafter absorbed by Aberdeen University. The program then expanded to include other Camphill places in Scotland. From the beginning, it sought to bridge the best traditions of Camphill and the best insights of academia. Coworker Angelika Monteux, who helped craft the curriculum, explained the vision through an analogy with anthroposophical medicine. "Health is not in opposition to any illness," she observed, "but the active balance between two ills. . . So why don't we apply this simple insight to ourselves and our activities? If we want our contribution . . . to be wanted and really helpful in a world where everything is moving and changing ... then we need to enter dialogue, exchange, partnerships."73

Long-term coworkers served as the primary instructors in a self-contained program that was expected to meet the academic standards of a research university. This posed some challenges, explained Angelika Monteux in an interview. "We, and then the students, had to learn to explain anthroposophy and Karl König's ideas and Camphill to people who had no idea, in language that they could understand. It wasn't easy." Though some Camphillers could not adapt to the demand that they "teach, not just preach," and that they incorporate other educational theories besides those of anthroposophy, she found it invigorating. She was impressed by curriculum consultant Steven Baron, a former young coworker who had pursued an academic career as an educational theorist. The university trusted him because "he was a recognized academic"; the Camphillers trusted him "because we knew he was our friend." Nevertheless, "he gave us a hard time. I still remember that after reading our students' papers, he said, 'I get the impression that they say, Rudolf Steiner said, Karl König said, they don't discuss anything. That's not the students' fault. That's your fault, the way you teach as if everything is written in granite stone.' I will never forget that." ${ }^{44}$ Another teacher in the program, Marjan Sikkel, noted that the ideological pluralism of the BA renewed conversations about anthroposophy in Camphill. "When I came anthroposophy was a bit of a dirty word. . . . But then these young people started to ask questions about it. It came back in through the front door [after] it had come out through the back door. . . . But it was for them one of the different methods, not the main one and only." ${ }^{55}$ On the other hand, another teacher in the program observed that some of the university's expectations pushed students to a more abstract and less experiential understanding of anthroposophy. Confidentiality rules dictated that participants not write papers about specific individuals, and this deprived them of the chance to integrate the ideas they were learning with their therapeutic practice and thus make them fully their own. This, in turn, distorted their relationship with anthroposophy itself, which is meant to be experienced in practice and not merely known abstractly. ${ }^{76}$

Though Camphill had a positive experience with Aberdeen University, the university ultimately decided to terminate the program, with the final cohort of students completing their studies in 2014. As far as I have been able to determine, 
none of the people at Aberdeen University who had worked directly with Camphill were part of this decision. Camphill had a narrow base of support within the university; many people there were entirely unaware of the Camphill-based BA program. ${ }^{77}$ The program's vulnerability was exacerbated by a well-publicized controversy over an attempt to endow a chair of anthroposophical medicine at Aberdeen University. Because anthroposophical medicine includes homeopathy and herbal remedies that have not been validated by mainstream experimental methods, many people believe it should not be taught at universities, and these critics persuaded university officials to reject the chair and terminate the relationship with Camphill.

Almost immediately, Camphill established a new program with Robert Gordon University, a much younger school that announced its curriculum in "social pedagogy" in 2015. Based in the School of Applied Social Studies, this curriculum promised to "provide a holistic focus on the individual, family and community; explore emotional, psychological, physical, spiritual and sexual development across the lifespan; emphasise group care and community-based practice with a critical and reflective approach to application." ${ }^{78}$ This program is not as directly controlled by Camphill as the old BA: students complete courses (mostly online) taught by instructors employed by Robert Gordon, while their work in Camphill is treated as a form of field education. Their work supervisors in Camphill are responsible for evaluating the students' learning logs and other assignments, but Camphillers are not invited to craft the assignments themselves. Unlike the old program, the Robert Gordon program enrolls students affiliated with non-Camphill work sites, though Camphillers are the majority. This brings the benefit of exposing Camphill participants to other styles of social care, and giving them the opportunity to share the Camphill philosophy with outsiders. Another difference is that anthroposophy does not appear at all on the reading lists of Robert Gordon courses. This has challenged the host communities to be more conscious about how they "bring anthroposophy in" to the everyday work experiences of the students. Newton Dee, for example, offers a "further education course" to both second year BA students and other coworkers in their second year at the community." This is designed to provide access to anthroposophical ideas and Camphill traditions that relate to whatever topics are being covered in the Robert Gordon curriculum. ${ }^{79}$

The reviews of the new program are mixed. One work supervisor said that she appreciated being forced to read some of the same recent studies that are assigned to the students, and being forced to explain why she made certain choices as a house coordinator. She even found it helpful when students asked to try things that had failed in the past-because sometimes they didn't fail the next time. "Doing this kind of work you can also become stuck. And that is dangerous as well. I think new people coming in with fresh eyes who really want to do this work, can help this process in not getting stuck." ${ }^{\circ 0}$ But another person who has supervised students in both programs complained that the new is not nearly as rigorous as the 
old one. "It is not stressful," she said, "but it is not as interesting. It is not part of what people are doing with their daily lives. It is really a completely separate thing and it is also very easy. ... . We have some really good coworkers who are doing it and they are sticking at it . . not because they think it is exciting but because it gives them a paper at the end." Other participants, she said, had simply dropped out. By contrast, in the old program "they were stressed and they were complaining a lot and they had to reflect and they hated it, but they all came out really happy. They really felt that they had developed." When I asked her if Camphill had the power to improve the curriculum, she replied that yes, "we have the power to do anything," but "it is a priority thing." ${ }_{11}$

In the United States, Camphill has benefited from a diversified system of higher education that includes many alternative colleges committed to experiential learning. As a result, Camphill Academy-which began at Beaver Run in 2003 and now offers programs at most of the Camphill places in North America-has partnered with four different schools for its degree programs. Its two bachelor's degree programs, in curative education and in social therapy, follow a five-year format. During the foundation year and the three years that follow it, students take onsite courses taught by Camphillers while performing the usual coworker duties. They then transfer into a one year "BA completion program" offered by either Prescott College (an environmentally oriented alternative college in Arizona), SUNY Empire State (a public university), or Excelsior College (a private school in New York that specializes in offering distance learning to adult learners who are underrepresented in higher education). These schools offer distance learning courses to round out the curriculum, leaving students time to complete a Camphill-based internship. ${ }^{82}$ In addition to these programs, Camphill Academy partners with Antioch University New England to offer an MEd in Foundations of Education. Antioch University, a low-residency graduate school, offers several degrees and certificates related to Waldorf education. It is an offshoot of Antioch College, which has a long-standing connection to Camphill and other intentional communities.

In just a few years, Camphill Academy has transformed the culture of Beaver Run, and to some extent of the other Camphill places in the North America. Prior to its founding, one long-time coworker told me, the Beaver Run seminar had fallen on hard times: "It was a bit wishy-washy. . . . There was some basic anthroposophy in the first year, there was [Steiner's] curative education course in the fourth year, but there was not a complete overview, a wholeness. It was whatever we can offer. ... And to be honest there was one written paper, and that was the student's project in the end." ${ }^{3}$ The whole community sensed that rejuvenation was needed, and they found an inspiring leader in the person of Jan Göschel, a veteran Camphill teacher who was then pursuing a doctorate in special education from the University of Cologne. Göschel's first step was to redevelop the existing seminar program and have it evaluated for college credit equivalency, a process that is offered by the New York State Board of Regents. Through that process, they 
identified partner colleges with flexible degree-completion programs, and were able to get their first student through Prescott's program in 2008. They absorbed Camphill Copake's seminar, which provided the foundation for the social therapy curriculum. When they added other communities, they took on the name of Camphill Academy. Along the way, they articulated a multidimensional mission. "There is an aspect of the mission that has to do with bringing in and educating the next generation of people who are going to be able to take on leadership roles within the Camphill Movement and carry that into the future," explained Jan Göschel. "Another aspect of the mission is to create a model of adult learning, a prototype for adult learning that is embedded in community that integrates study, contemplative practice, artistic process ... an innovative higher education project in its own right, apart from its function that it has for the Camphill Movement." Finally, Jan said, the academy is "an offering of the Camphill Movement to the world that allows higher education within which an anthroposophical impulse lives." ${ }^{8}$

By 2014, the program enrolled forty students a year just at Beaver Run, shifting the emphasis within the young coworker community from "general one-year volunteers" to "people coming to actually study curative education." "Is that a mission change?" asked Guy Alma, who experienced the transition. "I don't think it is a mission change, but the professionalization and expansion of the numbers of people in that program and the programmatic depth of it, it is an intense, intense program." ${ }^{35}$ Camphill Academy has sent a great many of its graduates-probably the majority-into settings beyond Camphill. Both graduates of the BA and individuals who skipped the degree completion year have been able to get positions in special education in Germany, where the credentialing regulations are extremely detailed. Jan Göschel also mentioned a graduate who is helping to start a Waldorf school in Thailand, and he spoke with particular pride of a graduate who was able to get a position as a logistics coordinator for Doctors without Borders in South Sudan. The recruiter who hired him "was looking for somebody [able] to work in tight quarters with a very diverse group of people, to deal spontaneously with unexpected situations, to see a situation and come to an insight of what to do about it." And that was just what the academy's curriculum offered. ${ }^{86}$

Because Camphill Academy's academic partners play a minimal role in the students' first four years, the program is more deeply rooted in anthroposophy than either version of the Scottish BA. This creates a division of labor within the Camphill Movement, with English-speaking students free to choose either a deeply anthroposophical program in the United States or a pluralistic one in Scotland. As noted above, founding director Jan Göschel identifies the development of anthroposophical education as one-third of Camphill Academy's mission, comparable in status to its role relative to Camphill. Though not all students would identify as anthroposophists, those who are skeptical of anthroposophy would be unlikely to persist in the program, even if they loved Camphill. "People tend to 
have a sense," Göschel explained, "that this is something that they want to wrestle with and work with." ${ }^{\text {87 }}$

Anthroposophy, Jan went on, "was never envisioned as a static body of doctrine but actually as a practice and orientation" of inquiry and contemplation. "What we are trying to do," he elaborated, "is to build fundamental capacities, capacities of observation, capacities of inquiry, and an orientation that allows you to look at situations that don't fit into any roster whether it is a conventional roster or even an anthroposophical roster or whatever." Students and faculty alike strive to "strip away preconceptions" and "look at the essence of the phenomenon, and out of that come to insights into what actually is going on in that situation." That allows them "to move the situation further, to transform it, to bring healing or balance or whatever it is. . . That is the point of anthroposophy." He also suggested that the immersive, experiential character of Camphill Academy's program gives it an advantage over classroom-based trainings for anthroposophical initiatives. Topics like reincarnation or the role of Christ can be "hot topics" in anthroposophical trainings because "people come with all their baggage around that." But "because of the threshold experiences that people have through life and work here, things open up in a natural way." ${ }^{88}$ One practical implication of this is that Göschel, unlike the people running the BA programs in Scotland, has worked very hard to align his curriculum with the work of the School of Spiritual Science at the Goetheanum. Indeed, since 2017 he serves as one of three international leaders of the Anthroposophic Council for Inclusive Social Development, the international coordinating body for all anthroposophical initiatives related to persons with disabilities. ${ }^{89}$

Though Camphill Academy and the Robert Gordon program are the two BA options for Camphillers in the English-speaking world, there are similar programs available in both Germany and Norway. These have a somewhat different flavor, simply because Camphill constitutes a smaller share of the totality of anthroposophical activity (and of anthroposophical social therapy) in those countries than in the English-speaking world. Thus, Germany has an entire university, Alanus, rooted in anthroposophy, and the German Camphillers' BA program is offered through a Waldorf teacher training center that is under the auspices of Alanus. The Norwegian program, similarly, is sponsored by an anthroposophical school rather than a mainstream university..$^{90}$ The comparable institutions in the Englishspeaking world, such as Emerson College in England and Rudolf Steiner College in California, do not offer accredited degree programs that would satisfy social care authorities.

BA programs have increased the number of young coworkers who stay for four years instead of one, and this has transformed the participating Camphills. "You would have a stable coworker in your house, in your workplace," observed one leader at Newton Dee. "If every year you get a bunch of new people in, it takes quite a bit of time to train. Whereas if you have at least a couple of people staying, they can help train these new young people and it is not all falling on me. Also for the 
residents it gives some stability." ${ }^{11}$ BA programs have provided a path to long-term commitment for a small but significant minority. Especially at Newton Dee, the BA program had a snowball effect on the long-term retention of young coworkers. A few graduates, some of whom had started families together, chose to stay on indefinitely, and-as one person pointed out-that "attracts more young couples with small children." ${ }^{22}$ The experiential structure of the program, moreover, "kind of forced Newton Dee to give some younger people additional responsibilities and naturally work their way into the management structure," explained Jake Vollrath. "I don't think Newton Dee resisted. ... As I was doing the BA I needed to show that I could take responsibility for different kinds of things . . . and I just sort of built it up in a very natural organic way." ${ }^{93}$ Undoubtedly, these programs are a major reason why millennials are better represented than Gen Xers in the community of lifesharing coworkers, though it remains to be seen how many of those millennials will embrace Camphill as a lifelong commitment. BA programs have also driven something of a wedge between those communities that are large enough to host a significant cohort of students and those that are not: the latter are, perhaps, having an even more difficult time recruiting long-term coworkers than they would if the programs did not exist.

Even as BA programs make it easier for some young coworkers to stay for four years or even longer, most Camphillers agree that it is harder today than it was in the 1970 s to convert short-term volunteers into long-term coworkers. Many stress generational differences, while others acknowledge that many of today's young coworkers come earlier in life and for different reasons than their counterparts in the 1960 s and 1970s. It is not simply that millennials are less idealistic than baby boomers: one can find a great many highly idealistic millennials living at ecovillages or running organic farms, and some of these same people are also at Camphill. But today there is a well-worn path that also brings many less idealistic millennials to Camphill, said Jonny Mallam-Clarke. Many young coworkers are more interested in working with children with disabilities than they are in intentional community, but even the interest in the children is "secondary to something else, which is this idea that . . you should get as much experience from life as possible. If you can, you should travel and experience life in a different country.... Often the choice is not made by them as to whether they come to Camphill. It is part of a very set trajectory now that you go from school, you have a gap year, you go to university. The gap year helps you get a job, and the gap year also helps you get into university." One consequence is that even those who fall deeply in love with Camphill feel that they still haven't experienced life and are thus not in a position to make an informed commitment to Camphill. Their situation differs dramatically from that of Jonny himself, and of other coworkers who arrive later in their twenties. "If you are coming to an intentional community in your later twenties, in a way something has gone wrong. If you come to an intentional community when you are nineteen, it is how it is supposed to be." Perhaps 
not surprisingly, Jonny left Camphill and joined the Benedictine order soon after our conversation-a sign of his hunger for a more permanent alternative to the social mainstream. ${ }^{94}$

As Camphills seek strategies that will entice more young coworkers to embrace Camphill as a lifelong calling, they also accept that most will not make this choice. As early as 1975, Thomas Weihs articulated the intrinsic value of shortterm coworkers, both for Camphill and for the larger society. Like the graduates of Camphill schools, Weihs noted, the "young, sensitive, intelligent people with a strong social sense, who leave Camphill after a few years of experience, training and learning" have "a tremendous potential power to make a contribution to society." ${ }^{55}$ I have heard a similar message from many contemporary Camphillers. "One is always," explained one person, "amazed by young coworkers who come and have never experienced doing care work before and how they mature and grow and change during the year of that kind of experience." "Seeing the new faces of young people who are coming to join the community just for a single year," echoed Crispian Villeneuve, "is one of the best things still happening in Glencraig." ${ }_{97}$ Another person, Neil Henery, stressed that some of the gifts that young coworkers bring to Camphill are possible only because of the brevity of their stay. "There is a lot of strength and value in having young coworkers from all over, Germany and the Continent and Korea, coming for a year or longer and going. It really brings spark and life into the community." ${ }^{98}$

Yet another Camphiller, reflecting on the difficulties in recruiting long-term coworkers, mused that "at some point I stopped thinking, why do people not want to stay in Camphill anymore, and I started thinking, my mission now is to give people this experience for a year. I started to then see that the young adults with special needs were my coworkers and that the people we were serving were the young coworkers."99 This sentiment was endorsed by Veronika van Duin, who recalled that her husband had always said that "our work isn't with the villagers, our work is with the young coworkers who come. . . Give them that experience and then let them go out into the world." She added that it doesn't "matter terribly much whether Camphill ... is successful or whether it closes down. What matters is all the people who've passed through [our] doors and taken some of it out into the world. Seeds for social renewal." ${ }^{100}$ At Beaver Run, coworker Carsten Callesen gave a concrete example of this, recalling how a man he had known as a young coworker fifteen years before came back for a surprise visit. Now a manager at Airbus, he said that he could trace many of the techniques he uses to manage his staff "back to the experience he had of community living." Of course, Carsten added, "in order to make this possible we also need the people who come and stay."101

Because they see young coworkers as emissaries of the Camphill spirit to the world, Camphills are intentional about the experiences they offer to these young people. Much more than students, villagers, or employees, young coworkers are offered a thoughtful introduction to the writings and ideas of Rudolf Steiner, even 
though it is assumed that most will not embrace anthroposophy as their spiritual path. While employees are typically slotted into narrow functions, young coworkers are given a holistic experience of community life. They participate in as many different workshops as possible. They are expected to be present at most meals, to accompany villagers to religious services, to share their artistic talents, and to participate in community festivals. Camphill life would be greatly enriched if the movement were equally intentional about the formation of employees, parents, and board members.

\section{EMPLOYEES}

Almost everyone agrees that employees are the fastest-growing constituency within the Camphill Movement. If "employee" is defined capaciously to include everyone who receives a paycheck for work performed at a Camphill, they are probably already the largest constituency within the movement, outnumbering not only lifesharing coworkers but also students and villagers. For the purpose of this section, I will define employee more narrowly to include only nonresidential employees - that is, people who engage in neither lifesharing nor incomesharing. This group surely outnumbers lifesharing coworkers with a long-term commitment. To my knowledge, every Camphill place includes at least some employees in this sense, while a significant minority of Camphill places-among them, most of the communities that are part of the Camphill Village Trust in England and Wales-include no long-term lifesharing coworkers.

This is a new situation, dating only to the beginning of the present century. A movement-wide census conducted in 1976 identified just 218 paid workers out of 4,262 persons affiliated with Camphill (thus 5 percent of the whole), while a similar census conducted among the North American communities in 2018 counted 439 full- and part-time employees out of 1716 persons ( 26 percent), compared to 236 long-term lifesharing coworkers (14 percent), 237 short-term lifesharing coworkers (14 percent), and 425 residents with special needs (25 percent). ${ }^{102}$ Scotland's 2015 census identified 396 employees (28 percent), 171 long-term lifesharing coworkers (12 percent), 252 foundation students ( 18 percent), and 536 persons receiving support (37 percent). ${ }^{103} \mathrm{~A}$ year later, the ranks of the employees had swollen to 469 , while the other categories remained roughly the same. ${ }^{104}$ The shift is even more dramatic than these numbers suggest, for both in 1976 and in 2018 communities in North America and Scotland had smaller shares of employees than other Camphill regions, notably England, Wales, and Ireland.

The change is evident at each community. At Soltane, one leader said that "Soltane for the longest time had maybe 1, 2, 3, 4 employees and a whole big bunch of coworkers." Then they expanded "program activities," including off-campus activities for their students, and suddenly "we are headed towards about 30 employees, and about thirty to forty coworkers," including young coworkers. "So 
it is getting close to parity." ${ }^{105}$ During my visit in 2013, Grangebeg had ten villagers, four lifesharing coworkers, five or six young coworkers, and four employees. ${ }^{106}$ Solborg in 2016 reported about ten employees, some of them part-time, alongside twenty villagers, thirteen lifesharing coworkers, eleven young coworkers, and eight staff kids. ${ }^{107}$ I mention these numbers because they represent the Camphill median: more dependent on employees than the large villages that have vested all decision-making power in lifesharing coworkers (such as Newton Dee, Loch Arthur, and Kimberton Hills), but less dependent on employees than the schools and elder communities that require highly specialized staff.

The sudden presence of so many employees within Camphill constitutes an existential crisis: Can Camphill truly understand itself as an intentional community if most of the people who inhabit Camphill places during the day do not actually live there? Can Camphill claim to be an alternative to the institutions that once housed persons with intellectual disabilities if the people providing care and support do so for the sake of a paycheck? And can Camphill claim to be a community rooted in the ideals of anthroposophy if it violates Steiner's admonition that work be separated from income? Some lifesharing coworkers answer "no" to all of these questions. They insist that places without incomesharing and lifesharing are not authentically Camphill, and that places with growing numbers of employees are at risk of ceasing to be Camphill. Even Camphillers who have participated in significant ways in the shift toward employment express tempered worries. At Newton Dee, a coworker who supervises many employees told me that "because I am in charge of employment at Newton Dee, I am also very anti-employment." She explained that although "I am very keen that we have best practices and ensure people's rights are respected," she is also "keen to keep [employment] low where possible." Even though she knows many people who say their work is not affected by the fact that they do it for money, she is skeptical. "It is easy to underestimate the power of what money, a direct salary, does to an attitude and an atmosphere. I think there are a whole lot of things that are not obvious now, but that would slowly destroy what we have."108

Other Camphillers reply that the employee group is the evolutionary cutting edge of the movement. Employees stand at the creative boundary between the intentional community and the larger society, poised to infuse communal values into the neighborhoods that surround each Camphill place. Yet this will happen only if the Camphill Movement finds ways to structure employment in alignment with communal and anthroposophical values, rather than treating it as an unfortunate concession to necessity or outside demands.

Several factors have contributed to the increasing numbers of employees in Camphill. Almost from the beginning, most Camphill places employed a few people to perform tasks that were peripheral to the core mission of Camphill and of little interest to lifesharing coworkers. This was the pattern at Camphill Village Minnesota when I first spent time there at the turn of the new millennium. In 1999 
there was, to my knowledge, one employed person in the village: an office manager who answered the phone, managed paperwork, and assisted the lifesharing coworker who was designated as the community's administrator. She was wellknown to everyone in the community, since she joined coworkers and villagers for lunch in village houses every day. But her life rhythms marked her as separate from the Camphillers. She worked nine to five and did not take a full hour of "rest period" after lunch. She was more truly "at home" in the nearby town where she lived with her family. Within a few years, the employee group increased to three, as the village hired a fundraiser and a staffperson responsible for recruiting young coworkers, both part-time. (For a time, my spouse played the latter role.) Like the office manager, these employees were well-known to the Camphillers, but not perceived as members of the community.

The numbers of employees performing office work has increased as the structure of Camphill has become more bureaucratic, in response to pressures from the larger society. When Camphill began, governments took little interest in the care of persons with intellectual disabilities and thus made few demands on the places offering care. Now, most governments mandate inspections, formal policies, and record keeping on issues ranging from meal preparation to safeguards against sexual abuse, and individualized plans for each person receiving care. They also demand formal credentialing from some of the people performing care tasks, especially educational and nursing tasks. Teachers at Beaver Run, for example, may have as many as three formal credentials: as state licensed special educators, as anthroposophical curative educators, and as Waldorf teachers. ${ }^{109}$ Many coworkers came to Camphill because they preferred face-to-face relationships over bureaucratic structures, and some of these coworkers are unwilling or unable to produce the sorts of reports and records required by inspectors. At the same time, most Camphill places have discovered that they can greatly increase their income by employing fundraising professionals. Guy Alma, who runs the development office at Beaver Run, told me that in about a decade he had expanded the office from one part-time person to three full-time employees in addition to himself-with a positive impact on the community's bottom line. ${ }^{110}$ And the immigration laws governing international coworkers have become increasingly complex, necessitating another set of specialized tasks that are of little intrinsic interest to the typical coworker.

The increase in the number of Camphill employees has also been driven by the decline in the number of long-term, lifesharing coworkers. The influx of baby boomer coworkers in the 1970 s and early 1980 os led to a great increase in the number of Camphill places, and when that influx slowed, many of those places found themselves short of teachers, workshop leaders, and residential caregivers. In 1982, an advertisement seeking new coworkers in the movement's newsletter provoked a surprised letter by a Camphiller who said he "would never have dreamt of the day where we would see our work depend on this mode of recruitment," but within 
five years "Coworker Needs" was a standard feature in virtually every issue. ${ }^{111}$ By 2000, the newsletter carried alarming articles that proclaimed that "wonderful, lively and thriving" Camphill places were "in a crisis and might have to be dissolved!" because of the difficulty in finding long-term coworkers. ${ }^{112}$

The loss of coworkers has forced most Camphill places to employ people to perform tasks that are also performed by lifesharing coworkers, and that are central to Camphill identity. This trend is most pronounced in Camphill schools and elder communities, because of credentialing demands. Adult villages, town communities, and training colleges have generally preserved a higher ratio of coworkers to employees, but most of these have still found it necessary to employ some workshop leaders. In some cases, villages have found that employed workshop leaders remain in their positions longer than lifesharing coworkers (even those who initially came with an open-ended commitment), and thus rely on employees to maintain stability and "relieve the coworkers of a lot of pressure." ${ }_{113}$ Villages are often more willing to accept employed persons as workshop leaders than as house coordinators, since the latter would undermine the core value of lifesharing. At many Camphills the degree of existential anxiety about employment is directly tied to the question of whether they've had to start employing house coordinators. When I visited Newton Dee in 2013, for example, they had recently appointed temporary coordinators of two of their houses in the hope that they could avoid resorting to employees. ${ }^{114}$ When I returned in 2016, the fact that they had maintained their commitment to lifesharing house coordinators was repeatedly cited as evidence of the overall health of the community, even though almost all of their workshop leaders were employees. Similarly, leaders at Beaver Run took great pride in the fact that "we have no employed staff in the houses," even as half of their teachers were employees. ${ }^{115}$

The increase in bureaucratic tasks and the decline in long-term coworkers has brought about a situation in which employees and coworkers work side by side in many Camphill places, with the ratio between the two shifting toward the employees. Other Camphills, however, have rejected either incomesharing or lifesharing altogether, making employment the standard model for all persons performing educational or care tasks. (Or, in some cases, they have made employment the standard practice for all long-term caregivers, but have retained short-term volunteers.) Usually, this has occurred in response to pressure from social care authorities or other government bodies, and it has taken place in roughly two waves. The first wave began as early as the 1970s, when Cresset House in South Africa began employing teachers with government-approved qualifications in anticipation of new regulations. ${ }^{116}$ It intensified in the 1980s, when several European governments rejected the practice of incomesharing as a violation of labor laws. These governments required that anyone performing a care task receive a just wage for their work; in some cases, they also mandated that different wages be paid to workers performing tasks of different levels of complexity. This posed a challenge to 
Camphill's egalitarian ideals, but it did not disrupt other aspects of Camphill life: employees could still be given housing as part of their employment package, maintaining the tradition of lifesharing. In many cases, coworkers who were forced to accept employment status set up voluntary incomesharing pools.

The European model of employment has proven attractive enough that some Camphills have adopted it even though they are not required to do so by their governments. In principle, Camphill incomesharing separates work from income, allowing each person to contribute their best gifts freely to the community, knowing that their basic needs will be fully met. In practice, it can create awkward injustices, if some people are comfortable asking for nice clothes and exotic vacations and others are not. It can also be time-consuming and emotionally draining for people to describe all of their economic needs and desires to their fellow workers. It is simpler, some Camphills have concluded, to give everyone a roughly equal salary, coupled with the provision of free housing, and to maintain a "social fund" to which people may apply for additional funds in case of emergency. Other Camphills believe that the practice of collectively distinguishing "wants" from "needs," though awkward, fosters spiritual growth and communal cohesion. Some of these places have preserved the practice of asking coworker individuals and families to request funding based on their unique needs, but then convert these requests into conventional salaries. This allows them to make the commensurate payments into government pension funds (such as Social Security in the United States), ensuring a level of financial security should those coworkers spend their retirement outside of Camphill. People who are compensated in this way generally regard themselves as incomesharing coworkers, not as employees. But there are nearly as many variations on this theme as there are Camphill places. In some, the distinction between coworkers and employees has virtually disappeared, as residential and nonresidential caregivers are compensated in the same way. In others, there is a bright line separating the groups, with certain leadership roles available only to those in the coworker category. Similarly, some employmentbased Camphills have salary structures that mirror those of mainstream social care, while others offer salaries that are either all equal or only slightly differentiated. One Camphill place, for example, told me that the ratio between their highest and lowest salaries was seven to six.

As employment has become more visible within Camphill, some lifesharing coworkers have chosen to become employees. The reasons for this are diverse, though finances per se are rarely the deciding factor. The graduates of BA programs, for whom their years as young coworkers were in effect their college experience, sometimes tell their communities, "I've finished my training and now I'd like to move out, but I'd be happy to be employed to come back and run the house or run the workshop." The community often agrees, one person told me, not with "great positivity" but because "we see that as the way it is going to go because that is what people want." ${ }^{117}$ Former staff kids, similarly, often have the skills needed to 
make a valuable contribution to Camphill but prefer to raise their own families in less intensely communal circumstances than what they experienced in their own childhood. Russ Pooler, for example, described his son's life as a paid manager at a Camphill school. "He grew up in Camphill so he loves the villagers and loves the life, but anthroposophy means almost nothing to him." When he began his job, the community was paralyzed by the opposition of a group of "old hardened anthroposophists" who wouldn't allow anything to change. "He managed to persuade them to leave. This wasn't the place for them. And now it has changed. It is a wonderful place now. It is thriving. People are happy. There are some committed coworkers there. That to me is the kind of freedom that you get in anthroposophy." ${ }^{118}$ In Norway, I met a community manager who moved out of Camphill in order to create a more stable home for his own special needs child, and in the United States I heard a similar story from a manager who said that she "lived in homesharing, lifesharing for twenty-seven years, and now I don't do homesharing anymore. I live with my son, separately, on campus. I am really grateful that that is a possibility." ${ }^{119}$ Another person observed that sometimes it simply boils down to the different preferences among individuals: "When I was a little kid, my mother asked my sister and myself, I can either give you a dollar a week, or you can just ask for whatever you need when you need it, and maybe you'll get it and maybe you won't. My sister said I want my dollar. I said I want to just ask when I need something. And both of us think we had the better deal." "120

A final factor has increased the number of Camphill employees in a numerically small but highly significant way. Several Camphill places have experienced crises-variously involving financial mismanagement, failure to comply with government regulation, abuse of students, villagers, or staff kids, or conflict among coworkers-that have provoked their governing boards to hire outside managers capable of bringing them back in line. On the face of it, this is an odd choice, since the same sorts of crises frequently occur in places with conventionally hierarchical management structures. I know of at least one Camphill place that brought in an employed manager in response to a crisis, and has experienced a similar crisis under the employed manager's watch. Yet it is understandable that boards often have a bias toward more conventional governance structures, since many board members are not deeply grounded in either the lived experience of intentional community or anthroposophical ideals. Both the laws governing the fiduciary responsibilities of board members and the government agencies that provide funding for Camphill places presuppose an administrative structure in which a single executive director is answerable to the board, and in times of crisis many Camphill boards opt for that model. There have also been cases when, even in the absence of a crisis, local authorities have demanded that Camphills appoint a single contact person for the sake of their inspections, and Camphill boards have complied by naming a manager. ${ }^{121}$ And so the "employed manager" has joined office workers, teachers, workshop leaders, and house coordinators in the roster of Camphill employee types. 
Some, though certainly not all, of these employed managers harbor deep reservations about the practices of incomesharing and lifesharing. In tandem with the boards that hired them, these managers have implemented employee-only models in many Camphill places outside of continental Europe. In some cases, they have limited or eliminated the practice of lifesharing as well-sometimes asking all coworkers to live offsite, sometimes refusing to accept residential coworkers with families, sometimes providing in-community housing to young coworkers but not to those who make a longer-term commitment.

In other cases, employed managers function as translators between the culture of Camphill and that of social care authorities. At one Camphill place in Ireland, I met a woman who had been brought in by the local authority to monitor the community's compliance with regulations, in the wake of a crisis. Technically, she was not a Camphill employee but a government employee, yet her role was similar to that of employed managers in other places and she had facilitated the process in which the community brought in its first employed manager. Since her government employers openly referred to her as their "eyes and ears", it was not surprising that she met some distrust on the part of the Camphill coworkers. "I was seen as the face of regulation coming in and the slippery slope of the end of life as they knew it." Still, she was able to make practical changes without disrupting the entire ethos of the community. In the past, she said, a problem would come to one group and that group "would say we have to take it to this group or that group, and somewhere in the midst of that it gets lost or it gets dated and then nothing ever happens." Her response was not to replace the groups with individuals, but simply to create a single "social care coordination group that would take responsibility for all the social care issues within the community." "They are struggling," she summed up, "to find a way to change while still maintaining an ethos and a culture and a value base." ${ }^{122}$

Given the diverse paths by which Camphill places have accepted the practice of employment, it is difficult to generalize about the experience of Camphill employees-more difficult, in fact, than it is to generalize about students, villagers, young coworkers, or lifesharing coworkers. All of those groups have social roles that are embedded in Camphill tradition, and understood in roughly similar ways from one Camphill place to the next. The one thing employees have in common, by contrast, is a significant dose of role ambiguity. Their presence at Camphill is widely regarded as a concession to necessity rather than an expression of idealism, and for the most part they are neither asked to uphold Camphill's communal and anthroposophical ideals, nor given the tools they would need to uphold those ideals in a meaningful way. Many have not been provided a formal orientation to Camphill traditions of the sort that is routinely provided to members of the other constituencies; others have participated in coworker orientations at their individual request. Some communities do routinely include new employees in their orientation practices, but these employees cannot assume (as coworkers 
most certainly can) that the Camphill employees they meet from other places will have been similarly oriented. Thus, when I ask Camphill employees whether they see themselves as among the people responsible for carrying Camphill into the future, they almost always struggle to form a reply, because they do not know whether the movement has truly invited them to play such a role. Many lifesharing coworkers also struggle to reply, but for a different reason: they know they are invited but are not sure whether they wish to accept the invitation.

This is unfortunate, because employees have enormous gifts to offer the Camphill Movement. Even critics of the trend toward more employment readily recognize that "some of our employed people are the best people." ${ }^{123}$ But employees" gifts, at the present time (2020), are exercised almost entirely within the narrow ambit of the specific task for which the employees have been hired.

Employees contribute, first and foremost, an enthusiasm for Camphill's holistic, communal ideals that they share with coworkers, students, and villages. Very few work for Camphill out of sheer economic necessity; most have embraced Camphill at least in part because it offers an alternative to the values of mainstream society. As one Camphiller pointed out to me, the choice to participate in care for persons with disabilities is itself a countercultural one that is not highly valued in the mainstream: "My experience is that if you do care work you don't work for money anyway. This is not the most highly paid profession." She also noticed a deeper level of commitment among the employees with whom she worked at Simeon Care for the Elderly. When she interviewed them as part of a conference presentation, "what came across very strongly was their own wish to create a kind of homely atmosphere in Simeon, to continue that sense of home even though it's not their own home." Significantly, many felt that this atmosphere would not be present without at least a few lifesharing coworkers. For these employees, in other words, being part of a social organism that included both lifesharers and employees was a core value. ${ }^{124}$ At Newton Dee, Russ Pooler reported that when their community offered a yearlong "ethos of Camphill" workshop for their employees, they were surprised to discover that "what they were most interested in was anthroposophy. . . . It is totally fascinating if you can actually see it happening as you can in Camphill. ... People are really interested in exploring. You gain an awful lot of good will." ${ }^{125}$

I also felt a strong sense of affinity with Camphill's lifesharing values from Fran Pioli, an employee whom I met at Cherry Orchards. She fell in love with the community during a practicum for a degree in occupational therapy, and when she graduated she persuaded Cherry Orchards that they needed a permanent therapist. She thought about becoming a lifesharing coworker, but because she had already been living locally for many years, she felt that "the strain of living so close to my old life without being able to access it in the same way ... would probably make me resentful." This is a challenge that doesn't arise for coworkers who leave their previous communities (and often, their home countries) when they come to Camphill. Fortunately for her, the coworker community at Cherry Orchards affirmed the 
particularity of her situation and accepted her as "an employee, a coworker, and currently part of the management group with a view to becoming one of the registered managers." She participates in all aspects of decision making except the allocation of trust money, and even there she doesn't feel excluded. Because she doesn't experience her role at Cherry Orchards as simply a job, she often participates in festivals that take place outside of her work hours-though she also feels free not to participate if she has a schedule conflict or isn't moved by a particular festival. She also said that the other employed coworker at Cherry Orchards, who had previously been a lifesharing coworker, related to the community in a manner similar to hers. Cherry Orchards also had employed gardeners with a more distant relationship, though one of them had recently begun participating in a weekly group designed "to teach coworkers about the basics of anthroposophy." ${ }^{126}$

Many employees, especially those who serve as workshop coordinators, bring an inspiring level of devotion to a particular craft or vocation. At Newton Dee, I was consistently impressed by the level of expertise and commitment expressed by the leaders of the garden, the bakery, the joinery, the toy workshop, and the craft workshop. These employees spent all or most of their time in a single work space, were in active conversation with practitioners of their craft beyond Camphill, and had thought deeply about how to cultivate an ethos of excellence among the adults with special needs who worked in their workshop. It is easier for a villager to think of herself as a baker or a gardener, rather than a recipient of services, if she is taking direction from someone who also sees herself as a baker or a gardener. To be sure, lifesharing coworkers could bring the same level of focused devotion to a craft, if the community asked them to do so. Many Camphill farmers are exempted from certain household responsibilities in order to make this possible. But the majority of lifesharing coworkers, historically, have been people who thrive on a diversity of tasks, and as the number of coworkers has declined, they have been stretched thin between household and bureaucratic responsibilities. In this context, the professionalism of workshop leaders creates a balance in the community that mirrors that of the larger society, reducing the risk that Camphills come to resemble the old institutions.

Employees can also deepen a Camphill's connection to the anthroposophical movement as a whole-though I have seen this only in a few places, and in most cases it is not even imagined as a possibility. In places where Camphill is a relatively small part of a vibrant local anthroposophical scene, employees may function as bridges to other initiatives. Many people employed at Cascadia in Vancouver, for example, had previous connections to the large local Waldorf school, and the same thing often happens in German Camphills. Conversely, in Camphill places that are isolated from other anthroposophical initiatives and that have few or no lifesharing coworkers, employees sometimes take the personal initiative to renew spiritual practices inspired by Steiner. In one such place, I met a carpentry workshop leader with no previous connection to anthroposophy, who had been 
inspired, simply by virtue of his community's past history, to educate himself in Steiner's thought. When I visited, he opened his workshop with verses from Steiner, offered with the enthusiasm of fresh discovery rather than the habit of long-standing tradition.

Employees also help the Camphill Movement think about how anthroposophical values might be instilled in society as a whole, and not simply in incomesharing communities. The anthroposophical ideal that work should be distinct from income can be (and has been) expressed in diverse institutional forms, as can the ideal that the economic sphere be governed by "brotherly" sharing. During the period when all Camphills had adopted the same forms, Camphillers didn't do much thinking about this; now, when they have a plethora of forms from which to choose, the conversation is active and energetic. "How does the Fundamental Social Law manifest itself?” asked Mischa Fekete at the Bridge Community in Ireland.

Does it mean that because they are paid they are not living out of the Fundamental Social Law, or does it mean that the key question is, do they work because they are paid or do they work because they want to contribute to this unique impulse and be a part of that and out of freedom give in that way and the payment is in a way a way of meeting their needs. And I think both happen. You can have employees that, really it is very clear, my hours are up and I am gone, and you have employees that come to every festival and every birthday celebration and everything else. And the key question is how can the community also communicate its vision, communicate what we are trying to do, make those events so exciting that of course people would want to be there? ? $^{127}$

Long-term coworkers who have moved from traditional to employment-based Camphills are thoughtful about this. One such person told me that the traditional system had never felt "equitable" to her as a single person, and that "there was a tremendous amount of time and energy put into what I felt were petty concerns." At the same time, she admitted, her conscience still prodded her to do more to promote "brotherliness in the economic sphere." Another person from the same community observed that in incomesharing communities the system could be "just weighted toward physical development, we need more cars, we need more house, we need more tractors, we need a better barn." But she also hoped for more conversations on economic sharing, especially as the needs of aging coworkers and villagers became more diverse and complicated. Yet another person in that community observed that they were just beginning to think about how best to provide financial support for retired employees and keep them appropriately engaged in the life of the community. Still another said that when she first arrived she "felt so rich," simply to have a small paycheck that allowed her to give money to a beggar. Later, she joined a study group on the threefold social order, and was thrilled to be in conversation with other people with different opinions, all striving to overcome their biases and judgments as they discern how to use money as a tool for greater connectedness. ${ }^{128}$ 
At another Camphill place that has moved significantly toward the employment model, two leaders told a complex story of how their community makes changes without abandoning Camphill's values - all the while insisting that the entire debate about employment is less significant than the conversation about how to more fully empower persons with learning difficulties. "To me it is immaterial whether somebody draws a salary or not," one said. The important thing is that no one feels like a second class citizen. ${ }^{129}$ Her colleague Adrian Bowden added that "we are trying now to make it clear that everybody who works here has some kind of role description, which includes an element of a review process around that role." Another priority is to create more flexibility within lifesharing, creating semi-autonomous living spaces when this will allow both coworkers and villagers to make personal choices about such things as vegetarian diets. Drawing on his previous experience in Norway, he mused that one long-term solution might be to "create a separate coworker organizational body" that would negotiate an overall staffing contract with Camphill based on standard salaries for specific professional roles, then distribute the payment according to its own incomesharing ideals. This would free the Camphill to interact with the social care authorities on their own terms, and the coworkers to "work through their stuff" on a more spiritual basis. ${ }^{130}$ Over the following years, these musings prodded the community to reorganize itself along the lines of Steiner's social threefolding. The senior coworkers organized themselves into a local "association" intended to serve as a "rights sphere organ where everyone in the community had an equal voice," while separate bodies operated in the economic and cultural spheres. ${ }^{131}$

Even in the places where conflict over employment is most intense, many Camphillers recognize that the situation is an opportunity for spiritual growth. In the midst of the conflict between the coworker community at Botton Village and the leadership of the Camphill Village Trust, coworker Ruairidh von Stein mused that "employees are no different than we are, because it doesn't make any difference whether you have money or not money. . . . There are karmic threads that pull everybody out into this particular spot. . . . If you spiritually start pulling the threads, whoever it is that is pulling these people together to serve a purpose, there must be a reason for that. . . . We are all in the same boat . . . and that boat can be about creating good neighbors, good relationships." ${ }^{132}$

Some of the Camphillers who are most deeply rooted in anthroposophy insist that the real threat to Camphill's spiritual integrity is not the fact that some people are employed but the sharp distinction between coworkers and employees. "The whole ethos of working out of loving and working because you want to do it is not impaired or endangered by the fact that you are paid for it," insisted one Camphiller (herself an incomesharer). ${ }^{133}$ Veronika van Duin made the point even more energetically: it is "a huge moral challenge," she said, "to practice the threefold social order in today's Camphill communities." In order to meet the challenge, one must "become a real anthroposophist," and the "first step" toward that end "would 
have to be that Camphill would stop separating waged, salaried people from volunteer coworkers, and would look at everyone as members of the Camphill community who work for the good of the development of the community, and it doesn't matter where they get their money from. It is irrelevant." Her abrupt turn from "real anthroposophy" to abolishing the employee/coworker distinction startled me, and at first I thought she might mean that Camphill needed to stop having paid employees. But her point was just the opposite. Her wish was for everyone in Camphill to start practicing the core disciplines of anthroposophy, which include overcoming biases and preconceptions and being open to new experiences and perceptions. Specifically, it "would involve those who are salaried wanting to take up the study of anthroposophy" and "volunteer coworkers [not thinking] they are better because they don't take wages, without recognizing how much in real cash terms they get." "Both are at fault," she said, then caught herself: "It is stupid to call it fault, but both need to take a step towards each other for community to survive." Ultimately, Veronika added, it might also require Camphills to "separate ourselves financially from the state so that they would have no tune to call," making it possible for Camphill to evolve a genuinely threefold social order. ${ }^{134}$

The sharpest critique I have ever heard of traditional Camphill lifesharing came not from an employed manager with no connection to anthroposophy, but from a passionately committed anthroposophist who began as a young coworker and then made an active choice to be an employee rather than a lifesharer. "I am going to be very honest," he told me. "Some people in relation to Camphill are milking the cow a lot. ... Everything organic, good cars, good clothes. A very expensive life. ... They are complaining all the time because they are working and living with people with disabilities, but they don't realize they have between five and ten [young coworkers] cooking, cleaning, and working with the [villagers], twentyfour hours, and their life is just to be there. . . . We want to provide the [villagers] a family experience. Is that a family experience? . . . I have my family, and when I go to my home there is not another three guys cleaning, cooking, and doing everything for me." He and his partner have twice refused to be houseparents because they believe that "life needs more fight. . . . If you really want to grow, you need to pass through some struggle. ... We need to cooperate with the world. And the only way we can cooperate with the world is to experience the world. That is why I think it is important to have employees." ${ }^{135}$

Though not all Camphillers would endorse the fullness of that critique, most recognize that employees have a precious capacity to mediate between the community and the world. They are the ones who move, quite literally, between the two places on a daily basis. One Camphiller described employees as a "bridging ring" around the community, noting that the parents of students and villagers often played this role before there were large numbers of employees. ${ }^{136}$

At the Bridge Community in Ireland, Mischa Fekete told me that the presence of employees has given the community a fluid and permeable boundary that 
expands or shrinks depending on the circumstances. "When you go to an inner esoteric celebration of a festival, suddenly the community shrinks to become a very small nucleus, and in a different moment suddenly the community experiences itself as being way bigger than its physical boundaries and including way more people." Though some people find that oscillation to be challenging, others "see it as the future, and part of the future mission of our communities to become impulse-bearers in the world rather than insular communities." ${ }^{137}$

One reason employees are able to play a bridge-building role is that most of them are natives of the place in which the Camphill is located. It is common, on the other hand, for a majority of lifesharing coworkers to come from other countries. When I visited Camphill places in Scotland, for example, I joked that I never had to contend with Scottish accents because I was always speaking to Germans with flawless English. (When Camphill Scotland assessed the potential impact of Brexit, they discovered that only 39 percent of long-term coworkers and 2 percent of short-term coworkers were UK citizens, compared to 67 percent of employees.) My ear for accents was challenged much more when I visited Blair Drummond, a training college that abandoned lifesharing (except for young coworkers) in a crisis a decade earlier. The employed managers who facilitated my tour were proud natives not merely of Scotland but of the Stirling district. For them, the strengths of their community and the strengths of the city in which it was located were a package deal, and this translated into an obvious capacity to help Blair Drummond's students fully access the resources of the city. It was equally clear that they had a long-term commitment to Blair Drummond itself, in contrast to many devoted Camphillers who, precisely because of their devotion to the Camphill Movement as a whole, willingly move from one Camphill place to another in response to those communities' needs. My observations at Blair Drummond were confirmed when I visited Garvald-an offshoot of Camphill founded by several of the founders who chafed under Karl König's authoritarianism-and met someone who started working there in 1981. In that year, he recalled, "I was the only Scottish person there," while most other coworkers were from Germany and Switzerland. Today, Garvald consists of a rural community with residential and day workshops, a smaller biodynamic farm community, and an energetic urban network of day workshops for people with special needs, staffed entirely by British people. ${ }^{138}$

Other employees play a bridge-building role because they also come from far away, but for reasons quite different from those of traditional coworkers. I observed this at Camphill Vidaråsen, located a couple hours' train ride from Oslo, which is the oldest and largest Camphill place in Norway. Like all the Camphill places in Norway, Vidaråsen has preserved a traditional system of lifesharing, but classifies all of its nondisabled residents as "employees" who earn wages in addition to receiving room and board.

Vidaråsen's embrace of the "employment" model had an unanticipated consequence: a large share of its employees, especially those with the nursing training 
required to do lifesharing with elderly persons with disabilities, are immigrants from the Philippines and Nepal. Unlike the Western volunteers who populate most other Camphills, these immigrants did not come primarily seeking community; they just hoped to earn enough to send a remittance to family back home. Vidaråsen's hybrid economic structure, in which many employees live in lifesharing households where their basic living expenses are all covered, makes it easy for them to send most of their paychecks home. These immigrants adjust easily to community life, since they grew up in tightly integrated traditional rural villages. The Norwegians and other Westerners at Vidaråsen have, in turn, embraced the distinctive gifts of their immigrant companions. At the time of my visit, for example, all the energy in the community was focused on the construction of a simple home that was intended as a pilot for a service project in Nepal. Several of the Nepali Camphillers were from a village that had been impacted by an earthquake, and Vidaråsen's plan was to build a home alongside local people, who would gain new skills for building similar homes throughout their community.

Employees, in short, are already a vital part of the Camphill organism, making significant contributions both as individuals and as a group. But at most Camphills, the potential contributions of employees are limited because the employee role is understood in functional rather than holistic terms. Employees are hired to perform a specific function, and rarely invited to form a holistic connection to the entire community. This begins with the hiring process. "We employ people to do what we are not able to do," said Diedra Heitzman of Kimberton Hills, and this is a practice that made sense when "what we are not able to do" consisted primarily of specialized tasks that were peripheral to community life. ${ }^{139}$ But the same attitude has persisted as "what we are not able to do" has expanded. Veronika van Duin summed it up more caustically, observing that Camphills don't "say to people who come, are you interested in community, are you willing to do anthroposophical training, because this is what we practice and you've got to learn what we practice. They don't. They just employ people who seem to be nice people with the right qualifications." ${ }^{140}$

One Camphiller, Mischa Fekete, told me that an administrator at his community referred to anthroposophical spirituality as "the fluffy stuff," and generally said that "I love it and it is great, but I don't know and I don't need to know." 141 In my experience, this is the attitude of the substantial majority of Camphill employees. What is more, it is the attitude that Camphill coworkers expect their employees to have. When employees constituted a small share of people affiliated with Camphill, it made sense to select people with a distant and indifferent attitude toward anthroposophy, since many communities were suffering from too much insularity and needed the perspectives offered by persons immersed in mainstream society. But few Camphills have shifted their hiring priorities as the balance between employees and coworkers has shifted. And those that have report that change can be challenging: "The trick is finding the people who are interested in living as community 
members regardless of money," explained Jake Vollrath at Newton Dee. "It is easier to find those people when we go for the unpaid model. . . . As soon as you start paying people you get all the other applicants ... and you are looking for a needle in a haystack." 142

The tendency to select employees based on their qualification for a particular task rather than their holistic commitment to the ideals of Camphills can have particularly damaging consequences when the employee in question is a manager. Again and again, I have heard coworkers make blistering complaints about employed managers who are hostile to lifesharing or anthroposophy, as well as more tempered criticisms of managers who want to do the right thing but are hampered by the fact that they "kind of get it on an intellectual level" but don't have an experiential grounding in Camphill's ideals. ${ }^{143}$ I often ask: why doesn't Camphill simply make familiarity with anthroposophical lifesharing a job requirement when it hires employed managers? After all, there are many anthroposophical initiatives, such as Waldorf schools and clinics, where people can gain some of the administrative skills that may be lacking among the coworkers of a particular Camphill place. Many Camphillers struggle to answer this question; others point out that the decision is typically made by boards rather than coworker communities, and the boards themselves have been selected without reference to their commitment to Camphill ideals. My own sense is that managers are often hired at a time when the community's most pressing problem is its lack of facility with the culture of the social care authorities, and so familiarity with that culture becomes the number one qualification. This creates a built-in conflict: the community sees the manager's role as primarily one of mediation with the larger society, while the manager assumes that her role is to oversee all aspects of organizational life.

After being selected in a functional rather than a holistic way, most Camphill employees receive an orientation that is equally functional. To be fair, this is not universally the case and it is changing. Camphiller Mischa Fekete, when asked about this, said "it is something that we are waking up to." But it is still the exception rather than the rule for employees to be offered the sort of comprehensive introduction to Camphill life that is a standard part of the young coworker experience. Indeed, Mischa went on to express worries about the legality of imposing anthroposophy on employees: "I don't think you can make employment of someone conditional on them being anthroposophists." ${ }^{144}$ Similarly, Carsten Callesen said that "we try to leave people free and also wait for them to pose the question," alluding to Rudolf Steiner's teaching that it is an imposition on someone's spiritual freedom to answer a question they have not yet asked. ${ }^{145}$ In some places, employees are free to choose whether or not to participate in the foundation year experience alongside the young coworkers; in some places, they must do so on their own time rather than as part of their paid responsibilities. Since employees typically have radically different life circumstances than young coworkers (for example, they are older, usually have family responsibilities, and are living in their home 
countries surrounding by networks of family and friends), orientation programs designed primarily for young coworkers can be uncomfortable for them. At Glencraig, Tracey McCoubrey, an employee who had participated in that community's seminar, told me that without that experience she never would have been able to step into a new role as an employed house coordinator. "That's really given me skills and the obligation to do it." But she also acknowledged that of the four other employees who started the seminar with her, only one completed iteven though all continued in their roles as employees. ${ }^{146}$

The work responsibilities of most Camphill employees, moreover, are defined in the same functional way that they were hired and oriented. An employee may be hired to run the carpentry workshop, or direct the fundraising office, or staff the community café, and these responsibilities will not change unless they apply for a different job. A lifesharing coworker, by contrast, might cycle through all of these tasks in response to the community's needs, and typically will have two or more quite different "jobs" simultaneously.

In suggesting that the work responsibilities of Camphill employees might be defined more holistically, I am not contradicting my earlier argument that employed workshop leaders offer an important gift to Camphill by maintaining a focus on a single craft. A holistic job description need not mirror that of the typical coworker who spends a few hours a week cooking, a few hours providing therapies, a few hours going to meetings, and a few hours running a workshop. It would simply need to incorporate some of the activities that instill a sense of membership in the community: eating meals in the houses, attending festivals, representing the community at regional or international Camphill gatherings. Many Camphillers worry that it is unfair to ask such things of employees, but the unfairness applies only if they are not incorporated into the job description in a transparent way. Were that to happen, Camphills would doubtless attract employees with more intrinsic motivation for community life. But so long as the focus is on minimizing the total number of employees, it is difficult to embrace such strategies. Indeed, one longtime Camphill employee told me that as the number of employees in his community rises, the boundaries between them and the life of the community have risen. When he was first hired, it was assumed that he would eat his meals in the houses, but now that is allowed only on special occasions.

My sense is that many Camphillers assume that a functional rather than holistic identity is intrinsic to paid employment. After all, Camphill historically opted for incomesharing and lifesharing because the founders believed these practices were most conducive to the sort of holistic community that would be both therapeutic and empowering for persons with special support needs. That was a reasonable choice then, and it is still a reasonable choice for many Camphills to cherish the traditional coworker model as much as possible. The mistake is the either/or thinking that assumes that just because lifesharing is holistic, employment cannot be. After all, there are viable-albeit far from perfect-models for work that 
is both paid and holistic in the larger society. In my experience, the roles of the university professor, the parish minister, and the family farmer are all defined in primarily holistic terms. Many anthroposophical initiatives that do not practice incomesharing are also intentional about cultivating a holistic understanding of their employees' roles. Camphill, in short, is well-positioned to reimagine employment in more holistic terms, if it were to make that a priority.

One reason that Camphill has not defined employee roles more holistically is that Camphillers are reluctant to impose aspects of Camphill life that are connected to anthroposophy on people who have not freely chosen anthroposophyyet it remains the case that there is an implicit expectation that villagers and young coworkers will participate in such activities, while employees will not. Whether the "opt-in" or the "opt-out" approach is more respectful of persons' spiritual freedom, it would seem logical to apply the same standard to all three groups, since all three typically come to Camphill without a personal commitment to anthroposophy. Another factor is that long-term coworkers are often appropriately aware of their own lack of insight into the employee experience, since many of them have never worked eight-hour, five-day jobs. But this is just to say that Camphills must find new ways to incorporate employees into decision making and into the long-term visioning process of the movement.

When I have raised this point, many Camphillers respond that employees do not want to take on leadership roles, cannot afford to be away from their families to participate in festivals, and so on. In part this is a result of recruitment strategies: if enthusiasm for festivals is not a criterion in hiring, it is not surprising that many employees lack enthusiasm for festivals. And it is certainly true that Camphill festival practices and decision-making structures, as they currently exist, are not very convenient for persons who have their own families and households and may live at a distance from Camphill. But this is just to say that Camphillers have not prioritized the full inclusion of employees in community life to the same extent that they have prioritized the full inclusion of persons with learning difficulties.

A final factor that limits employees' gifts to the Camphill Movement is the fact that they very seldom participate in it beyond their local community. At Glencraig, for example, Tracey McCoubrey told me that she felt empowered to participate in some larger events after she completed the seminar, but that other staff "sometimes don't feel that they have the support to do so." She also reported the poignant experience of attending a training at Camphill School Aberdeen and learning that people there used the term coworker to include everyone, both employees and lifesharers. She came back with renewed determination to promote more inclusive language at Glencraig. ${ }^{147}$

Fran Pioli, the Cherry Orchards employee who reported that she was fully included in all aspects of life in her own community, also said that when she attended a series of retreats on "Camphill essentials" that brought together people from many places, she was the only employed person there. The rest were all 
incomesharing coworkers from villages in rural areas. "I was the only thorn in the side of all things Camphill," she said, then clarified that this was mostly a joke. Everyone at the retreat embraced her with the same openness that she had always felt at Cherry Orchards. Still, it was significant to realize that other Camphills were not necessarily pushing their employees into leadership in the movement as a whole, and she continued to think of herself as "a Cherry Orchards coworker rather than a Camphill coworker." ${ }^{148}$

As far as I have been able to determine, employees who choose to participate in Camphill activities beyond their local communities are welcome to do so. In many cases, they are invited to participate; in some cases, their communities provide financial support for their participation in much the same way they might do for coworkers. It is, however, extremely rare for participation in the larger movement to be a mandatory part of the job description of a Camphill employee. Granted, it is not a mandatory part of the job description for coworkers either, but-especially for coworkers who join the inner community-it is a strong implicit expectation, and in any case coworkers do not work with such formalized job descriptions as employees do. Thus, many coworkers feel that they are needed by the Camphill Movement as a whole, while employees almost never feel this.

This may be the real barrier to full inclusion of Camphill employees. Employees, by and large, do not engage with the larger movement because so many coworkers do. If Camphill had been established on the basis of employment from the beginning, a subset of employees would naturally have gravitated to the regional and international organizations. They would have become the people leading Camphill into the future. (This is, for the most part, the pattern in the L'Arche movement, because that movement's preference for assistants who are single has greatly limited the pool of assistants who make lifelong commitments. Thus, nonresidential employees-some of them former assistants-dominate movement leadership.)

In somewhat different words, Camphill's current challenge is to recognize employees as an essential organ within the organism of Camphill. Too often, they are implicitly imagined to be more like a crutch or wheelchair-something that may be useful or even necessary, but not truly part of the organism. In the past, employees were chosen precisely to be exceptions, to do things that other Camphillers were unwilling or unable to do. Now that they are such a large component of the Camphill organism, they must be treated as Camphillers, from the way they are chosen to the way they are trained to the way they are invited to participate in shaping Camphill's future both locally and internationally.

In arguing for a more inclusive and holistic approach to Camphill employees, I am not at all suggesting that those Camphills that seek to maximize the number of lifesharing coworkers and to minimize the number of employees are in the wrong. If Camphill follows the developmental path of creative symbiosis, the number of employees may stabilize and the number of lifesharing coworkers increase-just as if it follows the path of evolving beyond community, employment may continue 
to grow as lifesharing disappears. Both developmental paths could bring significant benefits, and I am inclined to suspect that the movement will thrive best if different communities take different paths. But even in the model of creative symbiosis, employees will have important roles to play. They may well be the catalysts who help outsiders become invested in Camphill's communal values. So Camphill can only benefit from greater thoughtfulness about how to include employees in its future.

\section{PARENTS}

Employees, as the previous section has made clear, are the most controversial Camphill constituency, the group that has generated the most heated debate within the movement. There is no comparable debate about parents and other family members of Camphill students and villagers. Yet their role within the Camphill Movement has changed almost as dramatically as that of employees, and in a similar way. Early on, they were peripheral to the Camphill organism. They played a functional role without being invited to shape Camphill's future. Today, they are more physically present and emotionally connected to Camphill communities. Many yearn to be active partners with other Camphillers in shaping the future. Yet the movement has not yet evolved the structures needed to maximize parents' contributions.

Some Camphill historians have suggested that the founders sometimes mirrored the attitudes of the larger society in their negative view of the parents of persons with intellectual disabilities. Rudolf Steiner, in his course on curative education, traced the disabilities of some children to their parents' life choices. One boy, Steiner said, had trouble learning language because his mother's career as a stage actor had put "a considerable strain" on her astral body, which in turn inhibited the development of his own astral body. Another boy's challenges began because his mother felt so healthy during pregnancy that she was reluctant to give birth, especially after the sudden death of the child's father. Steiner did not tell these stories in a punitive spirit, but with a sensitivity for the complex subjectivity of the two mothers. His larger point was that everything is interconnected and thus worthy of attention in a holistic educational approach. ${ }^{149}$ The stories nevertheless validated the belief that children who struggled in their home context would benefit from being placed in an entirely new environment. By structuring their community as a boarding school, Camphill's founders implicitly promised that they could empower children with special needs more fully than parents could. They interpreted subsequent experiences in ways that confirmed this premise. The early records of Camphill School are filled with complaints about the regression and disruption that occurred when students made too frequent or too lengthy visits home..$^{150}$ I have occasionally heard similar complaints about parents in Camphill communities of the twenty-first century. 
These negative attitudes coexisted with significant cooperation between parents and Camphill. The Macmillans were extraordinarily generous to the budding movement, and in future years other families would exhibit similar generosity. Parents were crucial to Camphill's very survival as a German-rooted movement planted in the soil of World War II Britain. They "formed the outer ring of the community," one Camphiller told me. They weren't especially visible, "but they were the ones who would speak up" for the radical ideal of "education for everybody." 151

At least a few parents moved from the outer ring to the inner circle of Camphill. In 1959 Meg Farquhar, whose marriage was failing, took a job in the Murtle House laundry at the same time as her ten-year-old son Alistair enrolled as a day student at St. John's School. Alistair, according to Meg's obituary, "was born . . . with a frail constitution but with a capacity for sparkling joy and special forces of the heart." A year later, Meg became a Camphill coworker and Alistair a residential student. During her years at Camphill School, she served as both a teacher and housemother and became "renowned for giving guidance to the most challenging children and co-workers." She cofounded the Aberdeen Waldorf school. Both she and Alistair then spent the final years of their lives as part of the Newton Dee village community. ${ }^{152}$

As the Camphill Movement expanded, the parental role in fundraising also expanded. Not every Camphill parent has a Scottish estate to offer, but many have more than the average share of wealth and social connections. The benefit calendar of Camphill Village USA in Copake, New York, is a testament to the social capital of its parents. The Anne Ratner Concert Series, now in its forty-third year, features home concerts by many of New York's most prominent classical musicians. Initially these were in the home of Ratner herself; since her death, they have been continued by other families with Camphill connections and the wherewithal to turn their homes into music venues. ${ }^{153}$ The Joseph D. Freedman Bowl-a-Thon, similarly, "is the brainchild of the siblings of Susie Freedman, who has lived at Camphill since 1977." "154 "Families and friends" organizations play a leading role in fundraising for most Camphills, and several Camphill communities were first founded through the organizational efforts of parents.

Camphill Glencraig in Ireland used the occasion of its twenty-first anniversary in 1975 to expand its engagement with parents, hosting a series of conferences specifically for parents as part of a broader effort "to open its gates widely to the world."155 For many of the participating parents, this was a rare opportunity to "openly talk about their problems and their experiences to us [coworkers] and to each other." For the coworkers, it was a chance to break out of old prejudices against parents; as one reported, "it was a humbling experience to be allowed to witness the searching, the devotion and the triumphs of the guests who were with us and I felt that by coming here they were entrusting us with something precious: themselves, as well as their children, which we must try to be worthy of." 156 
When parents help Camphill communities raise funds, and even when they serve on their governing boards, their role in the movement can remain functional. Many parents hope to ensure that their children will always have a safe and stimulating place to live, but do not care whether that place will be structured as an intentional community, whether it will have a cooperative economy and a sustainable ecology, or whether it will draw spiritual sustenance from anthroposophy. As coworker Andrew Plant put it, "the parents of some of the residents of Camphill just cannot express their thankfulness and gratitude enough," but they also treat Camphill as a sort of "black box." "I have no idea what's in that box," they say. "I don't need to know, don't even try to tell me. I like what comes out of it." ${ }^{157}$

A few of the Camphill places I have visited have begun to evolve a more holistic way of connecting with parents. I have rarely visited Heartbeet Lifesharing without spending time with at least one parent. I have harvested crops alongside a retired Ivy League professor whose son lives in the community, and sung South African freedom songs under the direction of that same villager's mother. The community's longest-serving employee is a parent whose confident, outgoing daughter gives the lie to old prejudices about parents as a threat to their children's self-development. And the last time I attended a Camphill youth conference at Heartbeet, I was surprised to notice a large contingent of participants in their sixties. Heartbeet had invited its list of parents to the conference, as well as coworkers from across the region. The conference was designed to offer a holistic engagement with Camphill's traditions-with workshops on eurythmy, social threefolding, anthroposophical speech, biographical work, "nature sculpture," and clowning-and the parents were clearly motivated by a desire to enrich their own lives, not merely to check up on their children. Some brought friends along with them, further widening the symbiotic circle of people invested in Heartbeet's future. And when Heartbeet sent a large contingent to an international Camphill festival in Germany, that group included parents as well as coworkers and villagers.

The dynamic is similar at Cascadia, which is located in an urban neighborhood in North Vancouver and includes many day-program participants who live with their parents. Parents participate in daily work shifts in the garden and craft studios, and there is a regular gathering of parents who discuss topics ranging from social care policy to anthroposophical spirituality. As a relatively small, urban Camphill, Cascadia is invested in building deep relationships with all of its neighbors, and the parent group is central to their strategy for making that happen.

At Botton Village in England, parents embody Camphill's move toward creative symbiosis in a more activist way. For the past several years, Botton has been locked into a difficult struggle between the governing board of Camphill Village Trust, which favors the developmental path I have named as "evolving beyond community," and a group of long-term coworkers committed to traditional practices of incomesharing and lifesharing. In 2014, parents of Botton villagers played the leading role in organizing Action for Botton. This group raised funds, organized 
petitions, and sought out sympathetic press coverage for the coworker group, ultimately enabling them to reorganize a segment of the village as the Esk Valley Camphill Community. ${ }^{158}$ They serve as a model for parental activism at other places experiencing conflict over Camphill's future. At the same time, parents play prominent roles in many of the Camphill boards that have pushed the movement to evolve beyond community.

\section{BOARD MEMBERS}

Nonprofit boards exercise ultimate legal authority over most Camphill places. When Camphill was founded, it was assumed that boards would mediate between Camphill and the larger society, ensuring good relationships with social care authorities and a steady stream of donations and government funding, while leaving real decision-making power in the hands of long-term coworkers. The first time I attended a meeting of the Camphill Association of North America board, its chair encapsulated this view of the board's role. Alluding to the use of cosa nostra, or "our thing," to describe the Sicilian mafia, he told the gathered coworkers that he thought of Camphill as "cosa vostra"-your thing. Whatever the merits of this approach, it has eroded in the face of multiple crises in recent decades. Boards carry a legal, fiduciary, and ethical responsibility for the integrity of the organizations they serve, and in times of crisis they rightly refuse to delegate that responsibility. The question then becomes whether they will work to restore the integrity of the Camphill place in all its facets, or whether they choose to sacrifice certain aspects of Camphill life. Specifically, is it right to sacrifice the values of incomesharing, lifesharing, or collective leadership in order to preserve Camphill's status as a social care provider sanctioned by governmental authorities? The answer to this question often hinges on how the mission of Camphill is formally defined in its governing documents, on the background and values of board members, and on how their responsibilities were described to them when they were recruited.

Until recently, virtually all Camphill places were incorporated as "charities" or "nonprofits" in accordance with the laws of their host countries. In other respects, though, their board structures are diverse. In two nations, Norway and the Republic of Ireland, a single charity is responsible for all the Camphill places in the country. These charities are modeled on the Camphill Village Trust, which was initially created to administer Botton Village and then took on responsibility for planting additional villages and town communities in England, Scotland, and Wales. Its size is similar to the Irish and Norwegian charities, though it includes only about half of the Camphill places in England and Wales and no longer includes any Scottish communities. The constituent communities of these three large charities typically have their own local committees whose authority is subordinate to that of the overarching charity. Most other Camphill places-certainly those in the United States, Canada, Scotland, Northern Ireland, and Germany-are incorporated 
individually. They participate in umbrella organizations with their own boards, such as Camphill Scotland and the Camphill Association of North America. But in these cases it is the umbrella organization whose authority is subordinate to that of the individual Camphill places.

Camphill boards differ on whether it is appropriate for residents of Camphill to serve as board members. Many nations have laws prohibiting employees of charities from serving on charitable boards, or limiting the number of employees who can serve. It is not always clear whether these statutes apply to incomesharing coworkers. Thus, while from the outside it may appear that different Camphill boards have made different choices about whether and how to include coworkers (or employees or villagers), from the inside many boards believe that they do not actually have a choice at all, but have done what they are legally obligated to do. And some are simply confused: when I interviewed one coworker in 2015, he told me that he had recently been asked to join his community's board, then told at his first meeting that he was not eligible to serve. But when I followed up three years later, he informed me that he was ultimately able to join the board, since the community was not able to confirm the legal objection. They wound up deciding that a "representative minority" of coworkers on the board was "both welcome and necessary." 159

Though the composition of many Camphill boards has changed radically in the past few years, the fact of diversity is not new. In 1975, for example, one Camphill in Switzerland had a formal agreement in which the coworkers' group chose half plus one of the board's members and the parents' group chose the remainder. Another Camphill, also in Switzerland, had a board composed entirely of people from outside Camphill. ${ }^{160}$ (Perhaps not coincidentally, the latter community withdrew from the Camphill Movement in 1995.)

In the UK, the prevailing legal opinion is that at least 50 percent of the members of a charitable board must be "completely external," with coworkers, employees, villagers, and parents all classified as internal. It was a "game changer," one person told me, when that policy was clarified, because it meant that "if you didn't have enough time to recruit the right people," the external members "could suddenly turn the whole organization upside down." ${ }^{161}$ The Camphill Village Trust, for example, has responded to this policy by recruiting a board with three parents or family members of villagers, five people with extensive background in the social care establishment, and no coworkers or persons connected to anthroposophical initiatives. ${ }^{162}$ Other Camphill places in the UK have made radically different choices. During my visit in 2013, several people described Gannicox and Cherry Orchards as the two English Camphills that were most committed to traditional governance by coworkers, but their boards were quite different. Gannicox had received what they called an "extremely benevolent" legal judgment that allowed them to constitute a board with three coworkers, alongside a retired anthroposophical doctor, a retired Waldorf teacher, a coworker from another Camphill, 
and a retired therapist. ${ }^{163}$ Cherry Orchards, by contrast, had no coworkers on their board, but had also resisted relying on the mainstream social care establishment: their board included a retired psychiatrist, a former parent, and a former villager, among others. "They are actually people who understand what we are doing," explained Stephen Sands, "and we educate them also in anthroposophical thought processes, so they can think with us."164

When I visited several Irish Camphills in 2013, I was told that the Council of Camphill Communities of Ireland was undergoing a dramatic transformation. Historically, it had included one representative from each community, along with a few outsiders. Also historically, the community representatives had been coworkers, though by 2013 a few were employees instead. But this structure was judged to be too large, so they made a separation between a small council and a larger "neighborhood" in which each community would be represented. ${ }^{165}$ In 2018, the council had just seven members. According to the biographies published on the CCI website, two had careers in mainstream social care, one had a background in academia and environmentalism, three were parents of villagers, and one was a lifesharing coworker. ${ }^{166}$

The Camphill Village Trust in Norway has also wrestled with the question of how to represent all its communities without creating an unmanageably large board. As of 2016, each community had a village council composed of long-term coworkers. The charity, in turn, had a "council of representatives," chosen by the individual villages, with a guaranteed majority of coworkers serving alongside "representatives from a Camphill overseas" and "prominent figures in Norwegian society." This council of representatives, however, is not the governing body: its role, in addition to discussing issues in a general way, is to appoint a smaller statutory board for the charity. This board also has a mandated balance of Camphillers and outsiders. ${ }^{167}$

The board of Camphill School Aberdeen includes a social work professor who encountered Camphill through the BA program, an anthroposophical doctor who works in the Camphill clinic, a coworker at Newton Dee, and at least three parents or family members. ${ }^{168}$ As an umbrella organization, Camphill Scotland has a twelve-member council in which eleven trustees are nominated by the eleven constituent communities (resulting in a mix of coworkers, employees, and board members), while the chair is recruited from beyond Camphill. ${ }^{169}$

In the United States, it is rare or nonexistent for coworkers to constitute the majority of a board, but they are typically represented and together with parents they may constitute a majority. The bylaws of Soltane stipulate that at least 25 percent but no more than 50 percent of board members must be coworkers. ${ }^{170}$ At the time of my visit in 2014, Kimberton Hills recently softened a long-standing practice of maintaining a fifty-fifty balance between residents and nonresidents on its board, but it still had four residents on the board, along with one Camphiller from another community, one other committed anthroposophist, a doctor with 
connections to anthroposophical medicine, a Waldorf parent, a Camphill parent, and a few people with business skills but no deep connection to either Camphill or anthroposophy. ${ }^{171}$ It is also common for boards in the United States to defer to the internal leadership structures of the communities. At Beaver Run Carsten Callesen told me, "We do the prep work and we are well prepared. We go through processes before we bring it to the board. They may still ask questions, but they tend to have a strong faith in us that we know what to do and we know what we want and it is financially sound." ${ }^{172}$ Diedra Heitzman of Kimberton Hills similarly said, "We are not a start-up place and we are not at this point yet dying or transforming in that way. The board has felt fairly confident with what we've been doing, and very supportive.... We are making a lot of internal decisions that they agree to, but they also have the possibility to envision things and turn us in a direction that they feel we should go in." ${ }^{173}$ And the Soltane board, I was told, is trying to envision itself as a stakeholder board in which "everyone who is impacted by the community or part of the community has a voice in the governance of it." The stakeholder groups include students, their families ("which are two different stakeholder groups"), coworkers, employees, public officials, people who work in the field of social care, people who support Camphill "just because," and ("the only other stakeholder group that we haven't tapped into yet") customers of Camphill businesses. ${ }^{174}$

One practice that is widespread in North America and Scotland but virtually nonexistent elsewhere is that of inviting coworkers to serve on the boards of Camphills other than the ones where they live. Beaver Run and Soltane, for example, have a long-standing tradition of having representatives on one another's boards-a practice that has helped them maintain open lines of communication even as they have taken divergent positions in the debate over the use of employees. For many years, Camphill Minnesota had a board member who lived at Community Homestead, a village similar to Camphill though not formally affiliated with the movement. The Camphill Association of North America has even contemplated mandating that all of its constituent communities must have other communities represented on their boards. ${ }^{175}$

When I have asked Camphillers in other parts of the world why they do not do this, I have received a variety of answers. Stephen Sands said it was impossible to recruit Camphillers from other places because "people are just overdone," but noted that they did have representatives of other anthroposophical initiatives. ${ }^{176}$ There is an obvious challenge for the Irish and Norwegian charities, which would have to seek such representatives from beyond their national borders-though I must note that the driving distance from the Camphills in northern Ireland to those in the republic is about the same as that from Camphill Village Minnesota to Community Homestead. It is also the case that there are relatively few other anthroposophical initiatives in Ireland from which board members might be recruited, and some of these receive financial subsidies from Camphill. ${ }^{177}$

Camphills in North America have taken significant steps to incorporate villagers and other persons with learning difficulties into board governance. When I 
spoke to folks at Kimberton Hills in 2014, they did not mention having any villagers on the board, but the published list in 2018 included one villager, who was also identified as a "self-advocate." ${ }^{178}$ Camphill Copake's board also has one villager. Leaders at Soltane (a training college) told me that former students have served on their board almost from the beginning. "It has been an intention and actually for many years we have supported the people on our board and on the association board. . . . It is really something, how to make this process of inclusion real." Through their connection to the self-advocacy group Speaking for Ourselves, "we have a very educated group of people that is pretty strong and wanting to speak for themselves, or wanting to hold these advocacy roles." ${ }^{179}$

Currently, some Camphillers are asking whether incorporation as charities is the right structure for a communal movement. Ordinarily, a charity is accountable to its mission, not to its members, and for this reason charitable boards are usually self-perpetuating rather than elected. Arguably, an intentional community that is the home and workplace for a specific group of people should be governed more democratically. Some Camphillers, notably Andrew Plant in Scotland, have urged the movement to pay close attention to the cohousing movement, which has developed strategies to allow large groups of people to own property together and govern themselves democratically. ${ }^{180}$ Others have considered reorganizing as cooperatives or "benefit corporations" (that is, for-profit entities with a social mission). To my knowledge, the one Camphill communities that has embraced such a structure is Gannicox, a small community in England that is a hybrid of a town community and an elder community, and also sponsors a clinic and a kindergarten. In 2014, Gannicox's coworkers organized themselves into a Community Interest Company (the British equivalent of a benefit corporation), which allowed them to designate themselves as the sole directors. The Gannicox CIC contracts with the local county council to provide social care and support to residents with disabilities. Meanwhile, the original charity (called St. Luke's Trust) remains the landlord and maintains tenancy agreements with both the villagers and the members of the CIC. This arrangement fits well with British social care policy, which encourages persons with special needs to make separate arrangements for their housing and their care (in the interests of individual freedom). It also grants the coworkers partial autonomy from external boards, while ensuring their accountability to social care authorities. Though this plan is quite creative, its intent is simply to safeguard Gannicox against heavy-handed board governance. "It is hard," its architect wrote to me in the message announcing the change, "not to be gloomy about the outer shell of Camphill over here."181

Ultimately, the governance of a healthy organization should mirror its structure, with all constituencies represented and all representatives sufficiently connected to the organization as a whole that they will make holistic decisions rather than narrowly promoting the interests of their constituencies. Yet for most of Camphill's history, decision-making power has been concentrated in an unbalanced way among just one constituency, that of the lifesharing coworkers. Camphill boards 
began as auxiliaries to the coworker group and evolved into counterweights to that group-sometimes balancing coworker perspectives in a harmonious way and sometimes actively opposing the coworkers. The current developmental task of Camphill boards is to evolve beyond that polarity and become authentic meeting places for all Camphillers.

In many ways, the developmental task for Camphill boards is the same as the task for the Camphill Movement as a whole: how can it evolve beyond its coworker-centered beginnings so that all constituents can come together in the work of shaping Camphill's future? If this evolution is to succeed, a new and creative conversation is needed between Camphill's governing boards and the Camphill inner community. From one perspective, their roles are similar: both are located at a remove from Camphill's day-to-day work and charged with ensuring its overall integrity. From another perspective they are sharply differentiated, since the inner community focuses on the spirituality of Camphill, while board responsibilities center on finances, laws, and other outer structures. Their composition is also dissimilar: everyone in the inner community has a personal connection to anthroposophy and most have spent a decade or more living in Camphill, while relatively few board members have lived in Camphill or practiced anthroposophical spirituality. Since both have significant power to shape Camphill's future, the possibility for tension and misunderstanding is great.

One such tension erupted at a 1991 gathering of the inner community's "Movement Group," when board members were invited to the gathering but excluded from a few sessions. They complained, provoking a series of conversations that led the "Movement Group" to "become free of its former task as a Community organ" in $1995 .{ }^{182}$ In other words, the Movement Group was now in a position to bring all of Camphill's stakeholders together for conversations about the future of Camphill, and in particular to mediate the ongoing tensions between boards and inner community. But this shift did not clarify the mandate of either the inner community or the Movement Group. Currently, the Movement Group is governed by a document, prepared in 2016, that identifies it as a "non-executive organ of the Camphill Movement" and places primary emphasis on such tasks as "networking," "vision building," "active exchange, interaction, and communication," and "rais[ing] consciousness." It repeatedly names the inner community, the "international dialogue," and the Camphill regions as other organs that will be involved in Movement Group conversations, along with the Anthroposophical Society and its School of Spiritual Science. But Camphill governing boards are nowhere mentioned in the document. ${ }^{183}$

Thus, Camphill's evolution continues to move on separate tracks. Those governing boards that are most inclined to evolve beyond community are minimally engaged in the international conversations sponsored by the Movement Group, while the international bodies most committed to lifesharing and incomesharing are disproportionately dominated by coworkers. Governing boards and lifesharing 
coworkers hold vastly more formal power than other Camphill constituencies. To the extent that the two powerful groups remain polarized against one another, there is little prospect for genuine empowerment of the other constituencies. Yet when boards and coworkers are genuinely able to come together, there is real potential for all the constituencies to join in turning the movement to the path of creative symbiosis. That symbiosis will, in turn, involve new forms of interaction with the many contexts that have shaped Camphill's evolution thus far. 


\section{Camphill Contexts}

A communal movement, like any living thing, evolves in complex relationship with its environment. In the beginning, the relevant environment is small. The movement's growth is shaped primarily by the founders' creativity and strength of will, their capacity to get along with one another, and other internal factors. Movements that reach a second or third generation do so because their founders manage to open themselves to the surrounding world, at least to the extent of welcoming a new generation into movement leadership. This is what Camphill accomplished, rather splendidly, with the incorporation of baby boomers in the 1970 . By the time a communal movement reaches maturity, however, it does not simply live within an environment. It relates simultaneously to multiple contexts, each offering its own challenges and opportunities to the movement. The task of a mature movement is to allow itself to be transformed by each of its contexts, and simultaneously to transform each context by bringing to it distinctly communal practices and ideals.

\section{THE ANTHROPOSOPHICAL MOVEMENT}

Camphill's first context was the anthroposophical movement, and anthroposophy continues to exert a formative influence over Camphill's development. The founders of Camphill began as members of anthroposophical youth groups in Vienna. Like other clusters of younger anthroposophists in the 1920 and 1930s, they were impatient with abstract study and eager to translate their spiritual ideals into concrete practices. When the rise of Hitler forced them out of Vienna, they followed the migration patterns of anthroposophists before and since-to the British Isles, and soon thereafter to the United States, South Africa, Holland, and Scandinavia. Camphill has often planted itself in neighborhoods that were already home to multiple anthroposophical initiatives: the three Camphill places in Pennsylvania, for example, are located on or within a few miles of the estate of Alarik and Mabel 
Pew Myrin, who had begun promoting biodynamics and Waldorf education in that area in 1941. In other places, such as Columbia County in New York, Camphill has been the anchor that has drawn other initiatives to an area. More than any other initiative rooted in anthroposophy, Camphill holds anthroposophy's diverse impulses in a creative synthesis. It has never been satisfied merely to implement the indications Steiner gave in his course on curative education: it has also sought to cultivate biodynamic farms, share in the festivals and liturgies of the Christian Community, provide Waldorf education for children with and without disabilities, offer therapies rooted in anthroposophical medicine, practice eurythmy and other anthroposophical arts, and develop economic and social practices in accordance with Steiner's ideas about the threefold social order.

Rudolf Steiner's indications about how to work therapeutically with persons with intellectual disabilities provide a central point of contact between Camphill and anthroposophy. Steiner's curative education course continues to inspire Camphillers to work holistically for the empowerment of all people regardless of ability. Camphillers echo Steiner when they talk about seeing "the spiritual image of man behind every human being, especially those whose outward appearance or behavior was the most disturbed." Steiner's teaching about karma and reincarnation also motivates many anthroposophists to commit their lives to work with persons with disabilities. This connection is somewhat fraught: from the outside, it might appear that believers in karma would interpret disability as a punishment for the sins of past lives. This is not the anthroposophical view; it is not expressed in the curative education course, and I have never heard it hinted at by anyone associated with Camphill. Camphillers who are committed to anthroposophy will, on the other hand, typically say two other things: first, that human souls incarnate in disabled bodies to achieve specific purposes rooted in their karmic histories; second, that every human being has a dignity and integrity that transcends any particular incarnation.

Camphillers differ on how exactly to apply the idea that disability has a karmically rooted history. Is it enough simply to know that this is the case in general, or ought one to seek insight into the specific purposes underlying the disabilities of specific persons? As part of his esoteric teaching, Rudolf Steiner frequently gave his students insights into how their current incarnations had been shaped by their karmic histories. But anthroposophists have not always agreed on the capacities of people other than Steiner to engage in this sort of karmic research, or on whether it is appropriate to engage in such reflection about anyone other than oneself. Karl König, like his mentor Ita Wegman, was one of those who did share the fruits of his own spiritual research, and whose authority to do so was questioned by other anthroposophists. To some extent, the "college meetings" that he identified as one of the essential elements of Camphill were sites of karmic research. Coworkers gathered to reflect intensively on the whole person of one of their students-the child's parents, biography, symptoms, astrological chart, and much more-and in 
this context König would share insights into the child's karma. But Camphillers who were active in the movement during König's lifetime have different memories about the degree of emphasis on karma in college meetings. And few if any subsequent Camphillers have claimed capacities comparable to König's or Steiner's. The college meeting lost much of its centrality with the rise of Camphill villages and other adult communities, since all agree that it is inappropriate to reflect on the karmic history of an adult without that person's active participation.

When I have heard Camphillers talk about karmic history and disability, it is often in general terms: Jens-Peter Linde, for example, told me that "when in Hitler's Germany lots of disabled people were actually killed, they could inspire young people from the spiritual world to actually come find Camphill." This, in turn, helped bring about changes in public policy guaranteeing the rights of persons with disabilities. ${ }^{2}$ Many Camphill coworkers are more comfortable talking about their own karmic histories than those of the people with whom they live, and they also apply other spiritual concepts to make sense of their Camphill experiences. Several people told me that working with persons with disabilities has given them the chance to "experience the lesser guardian of the threshold"-a frightening spiritual being who confronts and challenges a person rising to a higher level of spiritual maturity, enabling the person to work more freely and consciously with their karma. "When you live in these multiplex communities and have relationships with people," one Camphiller explained, referring not only to persons with disabilities but to everyone living in lifesharing community, "they will form a mirror in which you see reflected from them your lesser guardian." He went on to challenge König's spiritual interpretation of disability, which, he said, encouraged benevolent paternalism by portraying all people with Down syndrome as unconditionally loving but weak in their egos. "I've lived with such people," but "people are far more complicated now." Many younger people with Down syndrome also have "autism, challenging behaviors, precocious sexuality." But he still insisted that the basic karmic task was "to recognize the biography of the people we are funded to look after" - to recognize "what their task is" and "give them opportunities, stretch them, give them challenges." And he fully endorsed the "fundamental principle of Camphill" that "the adult with learning disabilities is my teacher."

More frequently, I have heard Camphillers simply state that Steiner's teaching on karma and reincarnation helps them see the human dignity present in even the most profoundly disabled person. One person who had worked at Garvald told me, "From the perspective of reincarnation as Steiner described it, some people with learning disabilities in a previous life, might not have had learning disabilities, and we ourselves possibly might have learning disabilities in our next earthly life. . . . Steiner gave the picture of the violin with a broken string. People with learning disabilities could be viewed like the violin: they are wholly there, but with a broken string which affects how they play their whole tune. It might be something physical such as brain damage, but behind that person is a fully intact per- 
son. So that is really who you should be speaking to, the full person, with nothing but respect for that individual." 5 This approach contrasts with that of many mainline Christians who believe that each person has a single unique incarnation: for these Christians, a disability may be an integral part of someone's wholeness, not a broken string at all. In practice, though, the resulting ethos of respect for human dignity is much the same.

Steiner provided Camphill's founders not only with a method for developing the potential of persons with learning difficulties but also with a rationale for organizing on a cooperative, communal basis. Steiner laid a foundation for lifesharing in his stress on the healing potential of person-to-person encounters; he laid a foundation for incomesharing in his critique of wage labor, which he saw as inimical to human dignity because it treated people as commodities. Camphillers also draw deeply on one of Steiner's economic teachings, which he referred to as the "Fundamental Social Law." According to this "law," the well-being of any community will be enhanced "the less the individual claims for himself the proceeds of the work he has himself done" and "the more his own requirements are satisfied not out of his own work done, but out of work done by the others." ${ }^{3}$ Many Camphillers see this "law" as the heart of Steiner's social teaching, and they often say that the possibility of working out of love rather than for the sake of money was a major factor drawing them to the movement.

Yet Camphill's relationship with the anthroposophical movement-and, especially, with the Anthroposophical Society-has always been complex. None of Camphill's founders knew Rudolf Steiner personally, though a few of those who arrived at Camphill in the 1940s did. None of the other major initiatives rooted in anthroposophy received so little direct shaping from Steiner-unless one includes new impulses that emerged decades after Camphill, such as anthroposophical banking.

Because Karl König had an especially close connection to the Christian Community (the specifically religious expression of anthroposophy, which is structured as a small denomination with a distinctive liturgy), he forged a special relationship between Camphill and the Christian Community. In 1942 he and the leader of the Christian Community in Great Britain signed a formal agreement that Camphill would celebrate the sacraments of the Christian Community, which in turn would recognize Camphill as a sister community rather than one of its congregations. But this arrangement brought its own difficulties, and it was eventually annulled because it had never been ratified by the Christian Community's international leadership. Several Camphillers received ordination in the Christian Community, and the sacraments continued to be observed faithfully, but there was a "mutual reserve" between the two movements until 1973, when a series of gatherings were convened to bring them back into accord. ${ }^{7}$

Most Camphillers of the first and second generations learned their anthroposophy primarily from Karl König. Like his teacher Ita Wegman, König was a 
charismatic leader who freely shared the fruits of his spiritual research with his followers. No other anthroposophist has attracted as much ongoing study and devotion as König - evident, for example, in the publication of most of his writings by the Karl König Institute. One consequence of König's powerful personality is that many of the practices by which Camphill has remained connected to anthroposophy - and by which Camphillers measure the degree of their adherence to anthroposophy - are the distinctive fruits of König's spiritual striving, and are not practiced outside of Camphill. These include the Camphill inner community, the Bible Evening, and the practice of incomesharing, which Camphillers but not most other anthroposophists regard as mandated by Steiner's Fundamental Social Law.

Currently, the inner community, Bible Evening, and incomesharing are all in decline within the Camphill Movement: vital in a handful of places, struggling to survive in many more, and entirely absent in the rest. Many of the Camphillers I interviewed were thinking of this reality when they identified the declining centrality of anthroposophy as the most significant challenge facing the movement. Some, such as Jonas Hellbrandt, also observed that fewer Camphillers embrace anthroposophy "as an overarching kind of philosophy," even if they continue to apply anthroposophical insights to particular tasks or practices. ${ }^{8}$ Another coworker, Angelika Monteux, worried that others felt it was enough simply to uphold "the Camphill ethos and the Camphill ways," without reference to anthroposophy. Her response was to ask, "but where do the Camphill ways come from?"9

Yet few imagine that simply restoring the practices of Camphill's past would be an adequate solution. Steiner always understood anthroposophical initiatives as gifts from anthroposophy to the world, not as strategies for promoting anthroposophy directly, and in keeping with this mindset, everyone agrees that Camphills must remain pluralistic communities in which people of diverse spiritual paths are free to participate. Anthroposophy, moreover, is an evolutionary worldview, and so everyone agrees (at least in principle) that its appropriate expression in the twenty-first century will look different than in the twentieth. Many Camphillers express their vision for the future of anthroposophy in Camphill in surprisingly general terms. "The whole view of anthroposophy is to help us become more truly human, more truly who we are," one person told me. "If that can happen, then somewhere anthroposophy is alive." ${ }^{10}$ Another insisted that anthroposophy was not "a religion" or "the answer", but rather "something which adds on to most areas of life, and can give you a totally different way into something" because of its "inherent openness and curiosity and wish to look for meaning and truth." ${ }_{11}$

Typically, Camphillers who would like to strengthen anthroposophy in their movement are more critical of themselves, and of others committed to anthroposophy, than they are of the Camphillers who find little meaning in it. Javier Gonzalez Roa, a young employee with a deep connection to anthroposophy, emphasized that a special kind of person is needed to convey anthroposophy in an age that doesn't think it needs spirituality at all. "You can't feed a baby with meat," he said, alluding to a workshop that he found amazing but that turned off most 
of its audience with lots of "talk about demons and angels." A better approach is "to find the subject these people are going to be interested in, such as biodynamics or art or philosophy of freedom. You have thousands of ways to connect with people."12 Ruairidh von Stein, who insisted that anthroposophy was both the "anchor" and the "heart" of Camphill, also emphasized that "there are also other spiritual streams that we are working together with in brotherliness." For him, preserving Camphill's deep connection to anthroposophy was a personal task more than a demand to be placed on others. "I don't mind if there aren't many people who study it. I will carry it and share it in my own way through my meditation work, sending people thoughts, working with the warmth bodies around them.... Because we have to help each other. . . It is really important that anthroposophy lives." 13 This sentiment was echoed by a Camphiller who expressed many seemingly hopeless thoughts about anthroposophy in a hopeful voice. When I asked him to explain this contradiction, he mused. "It is individuals. Why am I here? Because of an individual. It is not because of an organization. Individual enthusiasm, individual interest. So my hopefulness comes from that."14

Many Camphill places today are experimenting with new structures for keeping anthroposophy alive in the movement. Around 2011, the Camphills near Aberdeen created two new groups for persons who were curious about anthroposophy. The Aberdeen Circle was designed, said Marjan Sikkel, as "a very intensive study group where we really try to do the exercises in How to Know Higher Worlds." ${ }^{15}$ In some ways, this group reflects a long-standing concern that existing anthroposophical study groups emphasize intellectual engagement with Steiner's writings at the expense of meditative practice; its agenda runs parallel to anthroposophical impulses beyond Camphill, such as the Goetheanum Meditation Initiative and Arthur Zajonc's work promoting meditative practice. ${ }^{16}$ This group is not exclusively for members of the Anthroposophical Society or the Camphill inner community, yet in practice most of its members are older coworkers also involved in those groups. Another new group works specifically with younger Camphillers, and much of its emphasis is simply on "the social aspect of it"-giving younger people a chance to engage with anthroposophy in a space that is not dominated by the older generation. ${ }^{17}$

Camphill's grappling with the place of anthroposophy often focuses on an essay by Karl König that identified "three pillars" of Camphill. These are the college meeting (a practice of reflection on individual students that is only practiced in Camphill schools); the Bible Evening (a weekly ritual of Bible reading, meditation, and conversation); and the Fundamental Social Law, which is the basis for Camphill's practice of incomesharing. By the turn of the twenty-first century, it was commonplace in Camphill publications for writers to state as uncontroversial fact that "all three pillars of Camphill are in serious trouble."18

The Bible Evening is a ritual in which Camphillers gather, on Saturday evenings, to reflect together on a Gospel text that they have been reading each day for the previous week. It begins with an extended period of silence, sometimes as much 
as fifteen minutes. This is followed by the reading of an anthroposophical verse, conversation about the week's events, and conversation about the week's text. The Bible Evening prepares its participants for the Sunday morning liturgy. Most commonly, that liturgy is the Festival of Offering (Opferfeier), a lay service that Rudolf Steiner created for teachers to use with their students in the Waldorf school movement. Karl König's early hope was that Camphill schools would use this service while Camphill villages would celebrate the Act of Consecration of Man, which requires the presence of a Christian Community priest. Because most villages lack a resident priest, they tend to use the Festival of Offering. ${ }^{19}$ The Bible Evening also prepares participants for the intervening night. An essential aspect of anthroposophical meditative practice is the notion that the spiritual work one begins during one's waking hours will continue in a different way during sleep. Participants in a Bible Evening often experience new insights on the morning that follows.

In the Camphill Movement today, the Bible Evening is a primary marker of whether a particular Camphill place is still vitally connected to anthroposophy. It is most typically practiced in individual houses, after a festive "Bible Supper." Since most Camphills serve their main meal at noontime and offer simple "breads and spreads" at the end of the day, just a few more indulgent spreads or a soup can suffice to distinguish "Bible Supper" from other evening meals. Especially in the larger Camphill places, some houses celebrate Bible Evening more frequently than others, but in general it is rare for any house to celebrate it every week and common for some houses (or entire communities) to have dispensed with it altogether. Those houses where baby boomer coworkers and/or inner community members are present are much more likely to observe Bible Evening than other houses. Indeed, many Gen-X and millennial house coordinators say that the reason they don't celebrate Bible Evening is because they don't know how to do it correctly. Some communities have addressed this issue by celebrating a single, occasional rather than weekly, Bible Evening for the entire community.

The fact that some Camphillers today observe Bible Evening while others do not is a faint echo of the early years of the movement, when Bible Evening was observed exclusively by members of the inner community. After Karl König established the Bible Evening on August 30, 1941, his companions experienced the new ritual as powerful and unnerving. It was the culmination of each week's work, both of the practical labors of the days and the spiritual study of the evenings. Things began, explains Angelika Monteux, with "a Bible Supper on Saturday with the pupils. ... They got all [dressed] nice . . . and the gospel was read, creating a nice peaceful atmosphere. Then the children went to bed, and the coworkers had the Bible Evening." ${ }^{20}$

The Bible Evening was observed exclusively by the inner community until König's "Third Memorandum" opened it up to other Camphillers. The inner community understood this as the final stage of a threefold sacrifice: first they had given up control of Camphill's economic life, then of its governance, and finally of 
its free spiritual life. They hoped that this would enable the Bible Evening to help new social forms germinate beyond Camphill, but they also anticipated accurately that "the Bible Evening will have to wander into the World, through valleys and heights, through the days and nights of human existence, through loneliness and distress, through joy and sorrow." ${ }^{21}$ Near the end of his life, Karl König offered further guidance in a "Bible Evening Memorandum" that underscored its esoteric continuity with the spirituality of the Moravians, Rosicrucians, and Templars. He affirmed emphatically that the Bible Evening was "a direct continuation of what lived among the Bohemian Brotherhood." "The waiting in silence and the opening verse stand under the sign of the Rose Cross," he wrote, while the meal and conversation prepare a "vessel" for the Gospel reading, allowing a "Grail Act" to "be fulfilled." König also anticipated the ongoing evolution of the ritual, for "what until now has only been partially realized is the metamorphosis of the Bible Evening from a tradition-bound Gabrielic form into a new Michaelic form." ${ }^{22}$

The Bible Evening continues to be cherished by many Camphillers of the baby boom generation, coworkers and villagers alike, for whom it retains an aura of esoteric sacrality. When a film was made about Camphill Vidaråsen in the 197os, for example, the Camphillers agonized over whether to allow the filmmakers to film the Bible Evening and decided to do so in part because one of Camphill's founders, Peter Roth, expressed approval of the idea. ${ }^{23}$ Another long-time coworker recalled that when he started in Beaver Run, Bible Evening was very strong and as a consequence, "the life in the homes was very rhythmical, very strong." ${ }^{24}$ Yet other baby boomers, and the vast majority of coworkers who arrived after the 1980s, struggle to connect the lived reality of Bible Evening with the vivid picture painted by Camphill's founders. One baby boomer coworker told me that he and his wife lead the only house in their large village that is committed to Bible Evening, and that even for them it is partly a matter of habit. "We have done that as a life pattern for many years now, and we intend to go on doing it." "25 "We talk about the glorious time of the Bible Evening," mused Angelika Monteux, "they weren't always glorious. They could be incredibly boring. Always the same people saying the same things and you sat there and didn't dare to say anything else.... Some people were very, very put off by that. Said it is all fake, and not true, and not alive anymore." ${ }^{26}$

Practical factors have also contributed to the decline of the Bible Evening. When Beaver Run began accepting more day students, for example, they had to shift their traditional "rest day" from Thursday to Saturday. This meant that coworkers as well as students suddenly had a real weekend. Many took the opportunity to travel outside the community, rather than participating in Bible Evening and the service that followed. ${ }^{27}$ Vidaråsen experienced a similar transition when they implemented a policy mandating two free days per week for all coworkers. ${ }^{28}$ Ruairidh von Stein, who grew up as a staff kid at Botton Village and returned there as an adult, told me that the village's increasing prosperity had undermined Bible Evening. "We used to have coffee just on Sundays, not the whole week. ... 
Saturday, the Bible Evening, was a very special moment, and Sunday was a special day. ... On the Bible Evening you are preparing for Sunday. But now on Sunday people are shopping with friends and going to market." ${ }^{29}$

Almost everyone agrees that if the Bible Evening is to have a future in Camphill, it must be transformed, but there is little agreement about what that transformation might entail. In a 2008 special issue of the Correspondence devoted to the Bible Evening, one contributor proposed that a change of name to "Community Evening" or "Biography Evening" would better reflect the current practice of the ritual, then added that "The Quickening" or "The Wellspring" would convey its aspiration in poetic form..$^{3}$ By contrast, a coworker at Heartbeet said that their Bible Suppers, though held only every few months, were characterized by "rambunctious debates about the Bible readings and what they could possibly mean." Precisely because Heartbeet was such a young community, she added, it could conduct Bible Suppers in a manner that signaled that "we struggle with this too, and we are figuring out what anthroposophy actually means, and it doesn't just have one answer, and we want to explore that with you." ${ }^{31}$ A similar sentiment was expressed by Steffi Hagedorn, a millennial generation coworker at Solborg who told me that "I'm not Christian, but we have Bible Evening. We always have it. I'm strongly into the Camphill Bible Evening." As a young coworker at Solborg she had experienced Bible Evening, but when she left the community and returned a few years later, it had disappeared. When she tried to bring it back, the villagers resisted, so she made it voluntary. "Okay, you can stay in your own room, we will have Bible Evening. And then-some took a week, some took two weeks, but then they were all here. And right now it gives something to the house. Something I really like about Camphill is the effort people make about things that are not technically necessary. We'd be fine without Bible Evening, we'd just watch a movie or go bowling, do something else. But it doesn't demand the kind of effort and it doesn't give back." By contrast, Bible Evening "lifts something ordinary to something special." ${ }^{2}$

When I visited Cairnlee in Scotland, long-term coworkers told me about the process of negotiation in their community. For many years they had practiced a rhythm in which the whole household-students and coworkers-celebrated a Bible Supper together, followed by a late night Community Evening specifically for coworkers. But a newly arrived cluster of houseparents found the every-Saturdaynight rhythm to be restrictive, so they proposed holding Bible Supper fortnightly and moving Community Evening. Coworkers who had been at Cairnlee longer suggested that the decision about Bible Supper belonged to the students, who "were quite clear they wanted to have Bible supper every Saturday." But they agreed to move Community Evening to Mondays. "We've done it for two years and we are getting used to it," one of them reported. "I can accept that it's just not the same thing that it used to be. It's a team-building meeting and it's still a very important part of the week but it is not the realm of the Bible Evening." ${ }_{33}$ 
The sacraments of the Christian Community occupy a place within the Camphill Movement that is similar to that of Bible Evening. Many of the older schools and villages offer either the Festival of Offering or the Act of the Consecration of Man on a weekly basis, often in a chapel built specially for that purpose. In my experience, the most devoted participants in these rituals are villagers, who usually constitute two-thirds of the gathered congregation. Many of the rest are young coworkers who are present merely to assist villagers from their homes. Longterm coworkers of the baby boomer (or previous) generation typically provide ritual leadership, but otherwise are not well represented in the congregation. I have rarely seen more than half of the coworkers whom I know to be deeply connected to anthroposophy attending a service, except during festivals or conferences. Another puzzling aspect of Camphill's religious practice is that villagers and students are not more frequently invited to become service holders or worship assistants, given their obvious commitment. To be sure, I have seen a few in these roles over the years.

Many Camphill places, especially those founded in the 1970s or 1980s, have adopted a mixed rotation of worship experiences. At Camphill Village Minnesota at the turn of the century, the long-term coworkers led the Festival of Offering one Sunday a month, and another Sunday each month there was a spiritually eclectic gathering, with responsibility for the gathering rotating among the houses. On the remaining two Sundays each month, community vans brought villagers and a few coworkers to Protestant and Roman Catholic services in the nearby town. A retired monk who lived a semi-eremitical life near the community's chicken coop provided additional transport for Catholic villagers committed to weekly attendance at the Eucharist. A coworker at Tiphereth, near Edinburgh, described a similar three-week rotation among a gathering, visits to the parish church, and a Christian Community service. The coworker noted that weekly services had both a "social" and a "spiritual aspect, because we are all related to some kind of a spiritual or religious realm of life." Likewise, he said, Tiphereth hosted a Bible Evening one week, "then a social supper, then a festive supper. We have three different qualities. But still again the most important is the social aspect of it." These variations on Camphill tradition were, in his view, the only authentic expression of anthroposophy, because "if you really look through [Steiner's] books, he said, seek and learn and develop and evolve. The last thing he wanted was that this is how it is and stay like that." ${ }^{4}$ Yet another Camphill place alternates religious services with an "ecumenical moment, a little gathering where any topic can come up which has to do with the human being in the more inner qualities." At one such gathering, for example, the Camphillers discussed recent research showing that dying rats have brain patterns similar to those associated with the "near death" experience in human beings. ${ }^{35}$

While Bible Evening and Christian Community rituals are unappealing even to some of the Camphillers who are most deeply connected to anthroposophy, 
the festivals are valued even by many who otherwise feel little connection to the work of Rudolf Steiner. "We celebrate all the Christian festivals, even St. John's and Michaelmas, which nobody else outside of Camphill ever celebrates anymore," explained Jake Vollrath at Newton Dee. "On a practical level they provide good landmarks through the year to help build a routine with the people that we work with. Christmas is obviously during winter, Michaelmas is kind of the start of autumn, Saint John's would be start of summer, Easter the start of spring. So they are quite important landmarks to identify what time of year you are in. But also I like the rituals. . . . And I quite enjoy supporting people who believe in it to take part in it. I quite enjoy taking part in a lot of it myself because I find a lot of beauty in it." But his household never celebrates Bible Evening, in large part because none of the villagers who live there want it. "They like to do Festive Supper, though, on Saturday. So basically instead of Bible Evening we are still having the buns, the tuna spread, the nicer meal, but without the Bible part of it. We still discuss things." 36

Older Camphillers regard the decline of the Bible Evening and Christian Community services with wistful sadness, but rarely with active opposition. From an anthroposophical perspective, the "free spiritual life" must be kept free. If people choose not to participate, there is little to be done directly. Consequently, the struggle over the role of anthroposophy in Camphill more often centers on the practice of incomesharing, and on the text that Camphillers see as the basis for that practice, Rudolf Steiner's Fundamental Social Law. Few texts of Steiner's are cited as frequently in Camphill, and the reason is clear: many Camphillers regard it as a crystallization of a truth that they have experienced personally.

"Egoism has become the force which separates people from people," explained Andrew Plant, a long-time coworker at Camphill Milltown, "and the only way to overcome this is if the individual works freely without expectation of monetary reward to serve either the social group he finds himself in or to serve the other person." ${ }^{37}$ One person said that the Fundamental Social Law made sense to her because she had grown up in Camphill "with the idea of not being salaried and separating work and payment," and consequently "to think of a shared lifestyle and shared resources was always how I wanted to live." ${ }^{38}$ Long-term coworkers with no personal commitment to anthroposophy are often just as enthusiastic about the Fundamental Social Law as those who participate actively in the Anthroposophical Society.

The Fundamental Social Law, articulated in 1906, was an early hint of the more comprehensive social theory, known as "social threefolding," that Rudolf Steiner promoted after World War I. Presented both as a description of the way society is and a prescription of the way it ought to be, social threefolding distinguishes three autonomous spheres: the economic realm, where "brotherliness" or solidarity is the guiding value; the "middle" or "rights" sphere, where equality governs the way people interact with one another; and the spiritual and cultural sphere, where 
perfect freedom reigns. Implicit in this approach is a distinction between work and income. Work, which involves human manipulation of the physical world, is in the economic sphere and therefore people ought to work for the benefit of others to the extent their capacities allow. Income, on the other hand, is in the rights sphere: as equal humans, we all should be guaranteed sufficient income to meet our basic needs. Steiner saw this philosophy as a middle way, neither capitalist nor socialist, and he refrained from direct cooperation with either Marxists or fascists in promoting threefold ideals. Subsequent students of Steiner have forged various political alliances: in the 1930s, many embraced the libertarian right because they opposed state intervention in the economic sphere; in the 1980s, anthroposophists were among the founders of the German Green Party.

Amid the diverse attempts to apply Steiner's social theories in contemporary life, Camphill's practice of incomesharing-in which work is performed by unsalaried volunteers whose needs are met by the community-is relatively unique. Few other anthroposophical initiatives are structured this way. Though many Camphillers regard the Fundamental Social Law as equivalent to Marx's dictum of "from each according to their ability, to each according to their need," this is by no means the only possible interpretation of Steiner's words. The Law resonates almost equally well with Adam Smith's argument for free trade and the division of labor, since both of those practices increase the extent to which any one person will have their needs met by the labor of others. Steiner had a basically positive view of the division of labor: "it precludes egoism," he said, because "one can only work for others, and let others work for oneself." This is not to say that Steiner was a conventional capitalist: he also said that if egoism is "present nevertheless in the form of class privilege," its coexistence with the division of labor will "lead to severe disturbances in the social order." 39

To make sense of the apparent contradiction between Camphill's interpretation of the Fundamental Social Law and that of other anthroposophical initiatives, I took a closer look at the three-part essay in which Steiner first expressed the Law. ${ }^{40}$ Currently, the Fundamental Social Law serves Camphill primarily as a decontextualized proof text; I have rarely heard Camphillers discuss any of the other material found in the essay. It was written before the founding of the Anthroposophical Society and thus has a different context from Steiner's subsequent writings on threefolding. Whereas Steiner developed threefolding in response to the postwar crisis engulfing Europe in 1918 and 1919, in the earlier essay he was concerned with the narrower question of how a spiritual movement (at the time, the Theosophical Society) ought to be engaged with social and economic questions. This gives it special relevance as Camphillers wrestle with their evolving relation to anthroposophy.

The essay, published in the journal Steiner edited on behalf of the Theosophical Society in Germany, was written in response to people who wondered what theosophy, with its commitment to "the highest human ideals," might have to contribute to 
early twentieth-century conversations about social justice. Steiner criticized those who said that theosophy could contribute nothing because of its focus on "the soul's inward life": these critics falsely imagined that theosophy was a collection of doctrines, when in fact it was a set of spiritual disciplines capable of "training the eye for a right conduct of everyday affairs." ${ }^{41} \mathrm{He}$ was even more critical of theosophists themselves for giving fodder to the critics by neglecting "the virtues of neighborly love and human usefulness" in order to "sit aloof, nursing in one's soul the latent seeds of some higher faculty." In any case, Steiner said, the entire debate hinged on whether "one regards the causes of the good and bad in social life as lying rather in men themselves" or in in "the conditions under which men live." Though people of good will took both positions, the former was the correct one, since the conditions that shape human lives have "themselves been created by men." 42

That sounds like a critique of Marxist materialism. Yet Steiner framed his argument in relation not to Marx but to Robert Owen, the nineteenth-century utopian socialist whom Karl König would later honor as one of the guiding "stars" of the Camphill Movement, alongside the Moravian teachers Zinzendorf and Comenius. ${ }^{43}$ Owen was well suited to this role of foil, for his utopian theory centered on the notion that the way to change individuals is to change society. Human nature, Owen believed, is entirely plastic (evidently with no karmic inheritance to work out!), and if humans are placed in a community structured around principles of equality and cooperation, they will naturally become cooperative and equal. Owen was also an appealing foil because he partially recanted the materialist assumptions underlying this theory at the end of his life, when he embraced the spiritualist movement. In Steiner's telling, the failure of Owen's "artificially devised scheme" at New Harmony forced Owen "to the conviction that any good institution is only so far maintainable as the human beings concerned are disposed by their own inner nature to its maintenance and are themselves warmly attached to it." Owen did not think deeply enough about the need to overcome human egoism, and contemporary reformers fell into the same mistake whenever they framed the "social question" as "What particular social institutions must be devised, in order that each person may secure the proceeds of his labor for himself?" It was at this point in the argument that Steiner introduced the Fundamental Social Law, suggesting that it offered an approach to social justice that stepped entirely out of the egoistic framework. The Law, he suggested, would lead to the creation of institutions in which "no one can ever claim the results of his own labor for himself, but that they all, to the last fraction, go wholly to the benefit of the community." By contrast, "he who labors for himself cannot help but gradually fall a victim to egoism." 44

Thus far, Steiner's argument does seem to point toward the creation of incomesharing intentional communities as the best way to institutionalize the Fundamental Social Law. But he then turned the argument in a decidedly anti-institutional direction. It is impossible, he wrote, to articulate a social 
"solution that shall hold good for all time," echoing his observation in an earlier esoteric lesson that "spiritual science has no patent recipe to tell anyone how to act in any specific situation." 45 The specific challenge of our time is to practice the Fundamental Social Law in perfect freedom. Since "compulsion is out of the question" in modernity, "the problem of the present day is how to introduce people into conditions under which each will, of his own inner, private impulse, do the work of the community." The Fundamental Social Law, in short, could triumph only through the accumulation of freely made individual choices: "Wherever this law finds outward expression, wherever anyone is at work along its lines ... there good results will be attained, though it be but in the one single instance and in ever so small a measure. And it is only a number of individual results, attained in this way, that together combine to healthy collective progress throughout the whole body of society." Steiner also insisted that the wellspring of such individual choices would be "a spiritual world-conception" able to "make a living home in the thoughts, in the feelings, in the will-in a man's whole soul." ${ }^{4}$

All of this can read as a critique of Camphill practice, to the extent that Camphill imposes incomesharing on coworkers without waiting for them to develop the "inner, private impulse" needed to choose it freely. Conversely, it could be used to clarify the intent beneath König's own invocation of Owen. Owen's whole life, he said, was a search for the Fundamental Social Law, but he "worked in the dark" because he lacked "the light of true knowledge and wisdom." Camphill's task, from this perspective, might be to continue evolving until it finds a way to practice incomesharing out of inner freedom rather than outer structure. An anecdote from Camphill's early history supports this view. When König asked coworker Morwenna Bucknall to do biographical research on Owen, she objected, asking, "What can he do for us?" König exploded back, "It is not a question of what he can do for $u s$, but of what we can do for him?"47

Steiner himself hinted at the possible existence of communities capable of manifesting in the present a level of cooperation that is mostly part of humanity's evolutionary future. There now exist "definite communities," he claimed, whose work "will make it possible for mankind, by their assistance, to make a leap forward, to accomplish as it were a jump in social evolution." But these communities were veiled in secrecy, as theosophy "does not find itself called upon to discuss these things in public." 48

Perhaps traditional Camphills could be regarded as among these evolutionarily precocious communities that are able to transcend egoism collectively rather than individually. Even if this is so, Steiner's essay makes it abundantly clear that Camphills that abandon incomesharing as a mandatory practice for coworkers need not thereby abandon the Fundamental Social Law as a guiding principle. These Camphills simply find themselves in the same position as other anthroposophical initiatives, and indeed modern humanity as a whole: challenged to help each individual achieve the "spiritual world-conception" that will empower them 
to do the work of the community in freedom. The Camphills that have created incomesharing pools among individuals who receive state-mandated salaries have been wrestling with this challenge for several decades, and the fact that most have struggled to maintain those pools does not necessarily refute Steiner's argument. It simply confirms his claim that the task of embodying the Fundamental Social Law can never be definitely achieved, but must be realized anew by each person in every age. As Camphiller Christoph Hanni put it crisply, "one of my definitions of anthroposophy is, when you don't stop thinking. . . . There is always some further way to go." 49

The demise of traditional incomesharing among coworkers may be an invitation for Camphill to consider what the Fundamental Social Law might mean for all of Camphill's constituencies: for villagers, employees, parents, and board members as well as coworkers. For most of Camphill's history, there has been an implicit assumption that as long as coworkers are practicing incomesharing, then the Fundamental Social Law (and perhaps, by extension, anthroposophy itself) is alive in Camphill. Now that that cannot be assumed, there is new space for other constituencies to embody it in transformative way. In Camphills without lifesharing coworkers, for example, villagers still live cooperatively, work on behalf of one another's needs, and receive income that is proportionate to their human needs rather than to the monetary value of their labor. Many people worry that the traditional Camphill spirit will gradually fade in these places because of the absence of coworkers, but this may reveal a lack of faith in the capacity of persons with learning difficulties to create authentic community, with or without coworkers.

Similarly, as I shall discuss later, the social care bureaucracy is currently calling for more "choice" and "individuation" in the provision of social care, with the implication that individuals with special needs should be able to choose their housing, their therapies, their workplaces, and their cultural activities from a wide menu of choices, rather than making a single comprehensive choice to participate in a holistic community like Camphill. Camphillers often worry that the demand for individuation is an expression of the very egoism that the Fundamental Social Law seeks to overcome. But perhaps it is instead an outgrowth of the modern emphasis on freedom that, according to Steiner, any attempt to realize the Fundamental Social Law must take for granted. If this is so, communities that accept the regime of individuation will in fact give their students and villagers an authentic opportunity to embody the Fundamental Social Law by freely making cooperative rather than egoistic choices. What would happen, coworker Mischa Fekete asked, if "the boundaries of Camphill became so permeable that the people within the community could work elsewhere, could be involved in other social impulses?" The result might be "a certain shrinkage," but it would also strengthen the community because "what is left at the center would be very real and authentic and stand the test of scrutiny." ${ }^{50}$ 
I do not pretend to know the future, and I do not assume that Steiner's account of how best to realize the Fundamental Social Law was correct in every detail. It may be that the "definite communities" of cooperation that Steiner mentioned almost as an afterthought will in fact be the main vehicle through which humanity moves to a cooperative future, and that the free choices of individuals will prove inadequate to the task of overcoming egoism. It may be that people who find themselves, more or less accidentally, in communities that expect everyone to work on behalf of others will gradually acquire the spiritual maturity needed to choose such behavior freely, while those who try to develop sufficient spirituality to make such choices without institutional support will inevitably fail. If these things are true, it would be a very good thing if some Camphill places continue to organize themselves around mandatory practices of incomesharing and lifesharing. But such an outcome would, I think, be a vindication not of Rudolf Steiner's account of social evolution, but of Robert Owen's.

Both incomesharing and the Bible Evening, I have suggested, are the fruit of Karl König's distinct interpretation of anthroposophy. It is possible that both could disappear even as the Camphill Movement deepens its connection to other dimensions of anthroposophy, not filtered through König's unique vision. It is now more possible for Camphill to draw on the resources of the anthroposophical movement as a whole than it was in König's time. The schism that rendered König a spiritual as well as political refugee is a thing of the past. Camphill has been an active participant in the ongoing process of reconciliation. In the 1970s, the Camphill founders each agreed to befriend one member of the society's executive committee, and to encourage younger Camphillers to get more directly involved. ${ }^{51}$ The 1970 youth conference featured a dialogue between Carlo Pietzner, representing Ita Wegman's side of the schism, and Hagen Biesantz (a member of the Anthroposophical Society's executive council) representing the other side. "It was symbolic that these two really came together and were working together," recalled Michael Babitch, and even though he didn't quite grasp the significance at the time, it instilled in him a keen sense of the spiritual power underlying Camphill. ${ }^{52}$ In recent years, the Anthroposophical Society's executive committee has included several persons whose heritage ties them to the excluded groups. Cornelius Pietzner, son of Carlo and Ursel Pietzner and himself a cofounder of Camphill Soltane in Pennsylvania, served as the executive committee's treasurer from 2002 to 2011. Karl König's granddaughter Joan Sleigh, who grew up in the Camphill communities of South Africa, joined the executive committee in 2013. The 1979 establishment of an ongoing Conference of Curative Education, Social Therapy, and Social Work, as part of the School of Spiritual Science and with full participation of Camphillers, was another milestone. Camphill Academy founder Jan Göschel is one of the leaders of this body, now called the Anthroposophic Council for Inclusive Social Development, and Camphiller Rüdiger Grimm was one of his predecessors in that role. 
Camphill and the Goetheanum also cosponsored a 2009 conference, in Dornach, on the theme of community building. ${ }^{53}$

Still, the old tensions between Camphill and the Anthroposophical Society have not disappeared altogether. "Many anthroposophists find Camphill odd," one person told me. "It is like a breed of its own." 54 Another reported that he "was almost a pariah" when he attended a conference on anthroposophical work with people with disabilities where he was the only Camphiller. The others, he said, had an image of Camphill as a place that was "still depriving individuals of certain basic human rights," albeit "in the nicest possible way, with arts and crafts and thinking of people as spiritual beings." Camphill, moreover, was "seen as dogmatic and ... basically not as open as anthroposophy is." ${ }^{55}$

What this means in practice is that some aspects of anthroposophy live in Camphill not as expressions of ancient tradition but as new elements contributing to the renewal of community life. One powerful way in which I have seen this happen is the way some Camphillers apply Rudolf Steiner's teachings about individualization, expressed in what is sometimes called the "Sociological Law," to the changing dynamics of their movement.

Rudolf Steiner taught that humans participate in a cosmic dance of spirit and matter, a dance in which spirit descends into materiality and then ascends, lifting transfigured matter up with it. The descending step of this dance is both tragic and necessary for the sake of cosmic evolution. Matter is not evil; rather it is the separation or imbalance between spirit and matter that must be overcome. Steiner taught that humanity is currently experiencing a descending cycle of materialism, hardening, and individualization. He also taught that we are on the cusp of an ascending cycle of spiritualization, liberation of dormant powers, and renewed community. In such a time, the challenge is to welcome the coming age of ascent without rushing the current age of descent, since it too has a cosmic necessity.

In his Outline of Esoteric Science, Steiner presented the evolutionary history of humanity on a cosmic scale, suggesting that humans had evolved in spiritual spheres corresponding to Saturn, the Sun, and the Moon before coming to our present earth. He divided earth history into "ages" that were subdivided into "epochs." We live in the fifth of seven post-Atlantean epochs. This epoch, which Steiner sometimes called the epoch of the consciousness soul, began in 1413 and will continue until 3573. It is characterized by an emphasis on "knowing and controlling the sense world," and by a division between sense experience of the physical world and spiritual experiences that no longer involve "direct perception." Steiner assigned both credit and blame for modern science and technology to this "one-sided turning toward physical life." Even though Steiner said that we are closer to the beginning than the end of the fifth epoch, he also said that "the sixth post-Atlantean cultural epoch is already dawning." This will be a time in which humanity's separated capacities will be knit back together as "we recognize 
the manifestations of the spirit in our observations of and experiences in the world of the senses." ${ }^{56}$

The effect of such teaching was to instill a creative ambivalence among Steiner's students. Spiritually speaking, the fifth epoch is an impoverished time from which we might wish to escape, but only by embracing its unique tasks can we help usher in the next epoch. This double mandate, to embrace individualization while preparing to move beyond it, is the reason that some anthroposophists are wary of community building initiatives in general and of Camphill in particular. They worry that communal groups rely too much on older patterns of community-on the rhythms of the tribe, the race, or the religious order-and are thus not able to envision the truly free communities of the future. This may not be a fair assessment of Camphill, but it certainly applies to some contemporary intentional communities. Both the evangelical Twelve Tribes and the free-love-oriented Tamera Ecovillage explicitly strive to restore tribal or monastic structures as an antidote to the ills of modernity. From the anthroposophical perspective, that is precisely the wrong way to go about building community.

Steiner's teaching about the age of the consciousness soul is related to his Sociological Law, which he articulated in 1898, at a time when he had not yet publicly emerged as a spiritual teacher and when he was closely aligned with the individualist anarchism of John Henry Mackay. This law holds that "at the onset of culture, humanity strives to create social groups; that is when the interest of the individual is sacrificed to the interest of these groups. Further progress leads to freeing the individual from the interests of the group, and to a free development of individual needs and capacities." 57

Camphillers, in part because they have heard the perspectives of other anthroposophists who worry that their communal approach is too backward looking, have embraced the Sociological Law as an anthroposophical tool that allows them to make sense of the way their movement has, in fact, evolved. One person said that the trend toward individualization "is a necessary process" and that "as each community is becoming more individualized, so the sense of brotherliness is changing as well." ${ }^{58}$ Another said that changes in Camphill reflected the fact that "overall society is much more focused on the individual. . . . I don't necessarily know if that is a bad thing or a good thing, it is just a thing. . . . The best thing we can do is try to work with that in as much of a community spirited way as we can. I think trying to fight change by and large is usually not a good way to survive. You need to work with the changes that are coming and try to make it fit with your ideals." ${ }_{59}$ Tom Marx made the same general point with a surprising twist: the founders of Camphill, he claimed, were keenly aware of the importance of honoring individuality, but a subsequent "generation or two generations, maybe three generations" of coworkers lost sight of the anthroposophical emphasis on individuality, and promoted community in a one-sided manner. This in turn led 
to a backlash, as some governing boards repudiated incomesharing and lifesharing in the interest of protecting the individual rights of villagers. ${ }^{60}$

In the beginning, a long-term coworker at Newton Dee explained, "we really were all together in the same boat. And we all had to work so hard in every hour of the day. We would do the housebuilding together and the farming." This resulted in a strong "feeling of community," but a relatively weak "care and therapeutic impulse." But as things began to run more smoothly and money began to come in, there was more "space . . . to see to the needs of the individual." This meant better care for students and villagers, but also more focused concern for the unique needs of coworkers and their families. Reflecting on a recent personal challenge, she mused that "if there is a crisis, people stand around people and they get them through it, even if it is a mess. . . This community is better at that than twentyfive years ago, from what I hear." She added that Steiner had anticipated this in the Sociological Law. ${ }^{61}$

Steve Lyons, who hosted me and my family on our first visit to Camphill in Scotland, was eloquent on this point, and on the need for modern intentional communities to be radically different from the communities of the past. "The human being in its earth evolution is reaching its culmination," he explained,

and that has to do with the development of individuality. ... We are so much more individualized, and that has affected the way that we think about each other, the way we behave toward each other, and also the way we behave toward the earth. ... We feel this distance from the natural world and want to find a way back to it again, but it has to go through the individualizing of human consciousness. ... The individuation process will make it possible for each of us to freely choose to relate to each other in the forming of groups who have common tasks. Before ... we were groups of people, but we were not freely choosing those groups.... From our time on, we need to promote the freeing of each individual from these groups so that we can choose out of a new wisdom which groups we wish to belong to and which tasks we wish to accomplish with others. That's the basis of modern community.

Inspired by this understanding of the task of intentional community, Steve has focused many of his Camphill efforts on promoting person-to-person dialogue within the "rights sphere" of the threefold social order. "People today do what they want to do," Steve acknowledged. "Each of us is an I." But from that starting point, "If I can find a way to welcome you into my work and recognize that you are concerned about the same things I am, we can go a certain way together in helping each other to achieve what we see as our common task." ${ }^{62}$ Steve's words were echoed by another Camphiller who, after bemoaning the abandonment of lifesharing at one community where he once lived, mused that "things come and go. ... It really has got to do with individuals. Who is interested in doing this or not doing it." 63

One way that Camphillers have put these ideas into practice is by drawing on the wisdom of the growing community of anthroposophically inspired organizational consultants, most of whom encourage organizations to embrace structured 
disciplines of listening deeply to one another. In part because of Steve Lyons's influence, for example, several communities in Scotland have used a program called Ways to Quality in order to meet regulators' expectation that they have a formal structure of quality assurance. Compared to conventional auditing practices, Ways to Quality is complex. It identifies twelve fields of organizational life, and within each field it distinguishes a "day field" of tangible tasks from a "night field" of subconscious reflection. Participants in the organization meet together to evaluate their performance in each field, following a set schedule that ultimately produces a comprehensive audit. The aim is "not standardization but a thoroughgoing individualisation of the activity comprising the service. This activity demands continual creative encounter and engagement from the participants." ${ }_{4}$ By keeping responsibility for evaluation within the community, rather than delegating it to an outside auditor, Ways to Quality allows Camphill to measure itself against standards of its own choosing; even more importantly, it ensures that Camphillers are in ongoing conversation with one another about their diverse experiences of community life. "The beauty of it," one participant told me, is that instead of having a manager who asks you to tick some boxes, "WTQ is rooted in the whole community." ${ }^{65}$ For the same reason, some communities have found it excessively cumbersome. ${ }^{66}$

More poetically, another Camphiller used the image of St. Martin of Tours to describe Camphill's task in the face of the Sociological Law. Confronted with a beggar, Martin cut his cloak and shared part of it. "He's not sharing [with] everybody else and leaving himself nothing like a good Christian who gives everything to the poor. He actually is sharing between what he keeps for himself and what he gives to the other. In a modern sense, that's the ecology of ... balance between your own inner development, the development of your warmth, so you can actually continue having the capacity to share." ${ }^{67}$ Another, someone who has moved her own community away from rigid adherence to traditional lifesharing, observed, "What is really still the quest for the philosopher's stone is: how do you really build community? What builds community? Is it really sleeping under the same roof twenty-four seven, getting on each other's nerves and learning how to not? Or are there other ways of building community?"68

The Sociological Law also challenges Camphillers to become more conscious about money. One unintended consequence of incomesharing is that many people don't have to think about money at all. For some, that is a big part of the attraction of incomesharing. But it runs counter to Steiner's actual teaching, which is that the only way to grow spiritually is to become increasingly conscious of everything, and especially of those things, like money, that knit us together with other people. "Camphill suffers," explained one coworker, "from its separation from the economic sphere as far as people don't have to think about money. It becomes invisible, which I don't think was ever the intention of the threefold social order." 69 A strict practice of incomesharing, in which members of a community fully disclose their economic needs to one another and work together to discern how much 
money is available for each need, would of course be one way of maintaining a living consciousness about money. But in practice, as Camphills have become more prosperous and capable of meeting virtually every need, the incomesharing communities have sometimes skipped this step, offering everyone a basic stipend and bringing only unusual needs to the attention of the whole group.

Seb Monteux, who was raised in Camphill and remains engaged in its evolution, applied the logic of the Sociological Law to the cultural sphere. In its early days, he said, Camphill appropriately put its emphasis on the needs of the collective and assumed that "the happiness or the needs or the nourishment of the individuals" would follow from that. "But I think we haven't managed to ... see ... that there is a shift and then it starts from the individual." He then observed that while cultural life in Camphill schools has become attenuated, "the villages have managed on the face of it to maintain and keep a rich cultural life. But the maxim of the cultural life is freedom. [And] there isn't that feeling that it is a free cultural life. It is often quite pressured, it is put in the diary sheets that here is the cultural life. And so there is a veneer that there is something very rich and active, but it doesn't come out of a real desire to make it free so that people participate individually." This problem, he added, exposed a contradiction in anthroposophical critiques of state bureaucracies. Though Camphills and Waldorf schools say "that we don't want the state telling you what the curriculum should be," they often wind up doing "exactly what we are trying to move away from, by saying, I know what is right for you, I know what is good for you." Ultimately, he concluded, the aim might be "to collectively get somewhere, but ... we have to come to it in our individual way. We might all get to the same place, but we can't get there in the same way."’o

I have met many Camphillers, including those who are deeply committed to traditional lifesharing, who welcome the changes that individuation has brought to the movement. The founders, Marjan Sikkel told me, "were very, very, very motivated and I've often heard they were sacrificing themselves." But now "that has really changed. I do believe in working hard but I don't like this sacrificing myself. I think there is a bit of give and take. Love they neighbor, don't forget thyself." ${ }^{\prime 1}$ Still, many of these plaudits are tinged with sadness, for Camphillers cherish the heritage of the past. "Consciously," one Camphiller put it, "we all know that this is just the way it is going. ... People need their own space.... But we will say it with a bit of sadness and longing. Because for me that is what I met in Camphill and that is what was precious to me and it is changing." ${ }^{2}$

Ultimately, the most important challenge that anthroposophy can bring to Camphill today is not to rest too comfortably with inherited forms of community life, even (and especially) if these have served the movement well in the past. Seb Monteux made this point sharply when he heard me say that certain telltale practices (such as the use of napkin rings to mark each person's place at the table) can be observed at Camphills anywhere in the world. "I think that is a good example of 
holding on to the forms," he replied. "Of course they are comforting. They allow an outer identity." But "actually the wisdom of anthroposophy is telling us that wherever you are it has to be different." 73 Jens-Peter Linde, writing in 2001, urged that the much-neglected Camphill pillars might survive not as rules but as imaginative "metamorphoses of living realities," observing that "life in Camphill becomes slavery if we cannot free it from the stranglehold of outer life." Ultimately, he suggested, Camphill's anthroposophical work could be fulfilled at the most basic level of human interaction, for "whatever I do, and whatever I experience, is part of an initiation which embraces everyone around me."74

\section{OTHER COMMUNAL MOVEMENTS}

Just as Camphill life has always embraced the surrounding web of anthroposophical initiatives, so too it has evolved in complex relationship to other networks of intentional communities, both past and present. Though not every Camphiller has a personal connection to other intentional communities, the founders were keenly aware of their communal antecedents and of the other community-building experiments that were springing up around them. Such awareness came easily, for Camphill had much in common with several of the most enduring communal impulses the world has known. From the Unitas Fratrum of the fifteenth century and Hutterites of the sixteenth to the kibbutzim and Bruderhof of the twentieth, central Europe has continually produced communities. It has also repeatedly subjected those communities to persecution, prompting them to seek refuge in every corner of the globe, and to intensify their communal practices as a survival strategy in challenging times.

The Unitas Fratrum traced their origins to the proto-Protestant preaching of Jan Hus (1369-1415), a Czech reformer who advocated for the use of the vernacular in the Christian liturgy and for lay people to be given both bread and wine in the Eucharist. After Hus was burned at the stake and his most radical followers were defeated on the battlefield, a remnant organized themselves in 1457 as the Unitas Fratrum and committed themselves to the pacifism and economic simplicity of the Sermon on the Mount. When Catholics consolidated power in Bohemia and Moravia early in the seventeenth century, the Unitas Fratrum dispersed and went underground, with bishop John Amos Comenius (himself based in the Netherlands) establishing structures of communication and mutual care that would keep their fellowship intact for another century. In 1722, some of those who had remained in Catholic-controlled Moravia migrated to the southeast corner of Protestant Saxony, where they were welcomed to the Herrnhut estate of the radical Pietist Nikolas von Zinzendorf. The confluence of Hussite and Pietist spiritualities led to the formation of the Moravian Church (sometimes also called the Bohemian Brethren), a mission-minded movement that was soon planting 
semicommunal villages in India, Greenland, the Caribbean, and several locations in North America, including an area of northeast Pennsylvania that is just fifty miles from several Camphill communities today.

In seeking places of refuge from persecution, the Unitas Fratrum and Moravians occasionally crossed paths with the Hutterites. A communal Anabaptist group that today comprises nearly five hundred villages and forty-five thousand individuals, mostly scattered across the upper plains and mountains of the United States and Canada, the Hutterites are the largest nonmonastic communal movement in North America and-I believe-the most enduring nonmonastic communal movement the world has ever known. Hutterite history has been shaped by four distinct refugee experiences. In 1533, founder Jakob Hutter led his persecuted followers from the South Tyrol to Moravia, perhaps passing through Karl König's native Vienna en route. An expanding Austrian Empire followed them there, and in the early eighteenth century a surviving remnant of just one hundred relocated to Ukraine, where they benefited from the Russian policy of offering unoccupied lands to new settlers. When Russian policy tilted back to intolerance, four hundred communal Hutterites, along with others who had abandoned strict community of goods, migrated to the Dakotas in the 1870s. As pacifists, they resisted the draft during World War I and after two Hutterites died in military prison, the movement crossed the Canadian border in search of refuge. New laws honoring conscientious objection have since allowed Hutterites to plant new colonies in the Plains and Pacific Northwest, though about two-thirds still live in Canada.

Long before the Hutterites arrived in North America, communal history in the United States was dominated by German-speaking Pietists with a spirituality similar to the Moravians. Among the earliest of these were Johannes Kelpius's Society of the Woman in the Wilderness and Conrad Beissel's Ephrata Cloister. These groups blended the activist, biblical spirit characteristic of all Pietists with a strong emphasis on the esoteric or hidden dimensions of Christianity; in this respect they had much in common with anthroposophy. Both were planted in colonial Pennsylvania, each about thirty miles distant (in opposite directions) from the Camphill places. More enduring Pietist communities came later: the Harmony Society in Pennsylvania and Indiana maintained a strictly communal organization (holding all property in common) from 1805 to 1905 ; Zoar in Ohio did so from 1817 to 1898 ; and Amana in Iowa endured from 1854 to 1932. All three of these groups prospered economically and experienced the developmental trajectory I have labeled "evolving beyond community." Younger generations abandoned the practice of community of goods, but chose neither to disperse nor to abandon their religious heritage. All three movements survive today as towns, religious congregations, and historic sites that are managed in part by descendants of the original community members. (Amana also survives as a prosperous cluster of businesses.)

The founders of Camphill were not aware of all of this history, but they had a keen sense of their dependence on three interwoven communal strands: the 
mysterious tradition known as Rosicrucianism, the work of the Moravians, and the utopian socialist theories of Robert Owen. Karl König traced the origins of the community-building impulse in the West to the "Fama Fraternitatis," a mysterious document that appeared in 1610 and described a secret brotherhood, symbolized by a Rosy Cross and devoted to uncompensated acts of healing. The Rosicrucian ideal, König said, had inspired "an almost continuous and uninterrupted flow of trials in community building." (He also claimed that the Rosicrucians themselves continued the spiritual work of the medieval Templars, and was delighted when he discovered that the Templars had once been active just across the river from the original Camphill estate.) Within the Rosicrucian stream, he identified three initiatives as "stars" for Camphill: Johannes Amos Comenius's attempt to form a "universal college" in the wake of the Thirty Years' War; Count Ludwig Zinzendorf's Pietist community at Herrnhut; and Robert Owen's communities at New Lanark and New Harmony in the nineteenth century. König acknowledged that none of these initiatives had been entirely successful; Camphill's goal was thus not to repeat their efforts but simply to "walk in the trials and errors and achievements of these three great pioneers." He identified them as the inspiration for three "pillars" of Camphill practice. The college meeting, in which teachers gather for a holistic study of an individual child, derived from Comenius's educational theories, the Bible Evening from Zinzendorf's piety, and the Fundamental Social Law from Owen's ideals. ${ }^{75}$ In framing Camphill practice as a reformulation of earlier communal ideals, König exemplified what communal studies scholar Joshua Lockyer has called "transformative utopianism": the tendency of new communal movements to learn from the fading ideals of their predecessors. ${ }^{76}$

Karl König and the other founders were also aware of other communal movements that responded to the global crises that had driven them from central Europe to Scotland in 1938. The kibbutz movement began in 1909, a generation before Camphill, and experienced its most rapid growth in the 1930s and 1940s. Like König, many kibbutz founders were Jews from German-speaking territories; also like him, most were influenced by socialist youth movements. Just as the Camphill founders welcomed developmentally disabled "refugees" from an uncaring society, as well as refugees from communist East Germany, so too the kibbutzniks welcomed Jewish refugees from persecution in both Europe and the Middle East. The kibbutzniks achieved a dual success: they simultaneously established a communal culture that was robust enough to last for generations and helped lay the foundations for the new state of Israel. The kibbutzim achieved a peak population of 129,000 in 1989; today, about 270 communities are home to 100,000 residents. Camphillers experienced kibbutz life as early as 1958, when Carlo Pietzner traveled to Israel for an International Federation of Children's Communities gathering hosted by Youth Aliyah. He was impressed by the "spectacular show of willpower evident everywhere" in the young country, intrigued by the early kibbutz practice of maintaining a "children's community within the bigger 
community, with . . . a considerable extent of self-determination," and troubled by the possibility that all the idealism might serve no higher end than "the establishment and the maintenance of the state." Camphiller Marianne Sander visited Israel around the same time and reported in more detail. Like Pietzner, she was impressed by the energy of the kibbutzim but troubled by their lack of spirituality. Referring specifically to the practice of children's villages, she mused that parental devotion "has been forgotten in the life of the Kibbutz and it is being replaced by patterns and systems into which life must fit itself. Life is there to uphold the system; not the system to uphold life." 77 Perhaps because of these reservations, Camphill never forged a deep bond with the kibbutzim.

Other communal movements were founded by idealists who were troubled by the economic crisis and subsequent militarization of the 1920s and 1930s. The Bruderhof was established by Christian pacifists who modeled their communal settlement in Germany on the Sermon on the Mount and on the earlier example of the Hutterites; like the Camphillers, they migrated to the UK and then beyond after being attacked by Nazis. Taena and Iona sprouted among radical Christians in the UK, just as did Koinonia and the Catholic Worker in the United States. Also in the United States, Arthur Morgan-president of Antioch College and chairman of the Tennessee Valley Authority-promoted cooperative rural communities as alternatives to what he saw as the failures of industrial society. In 1939 he organized the Celo Community in North Carolina, in which economically autonomous households owned their own homes but leased land from a community land trust; a year later he organized the Fellowship of Intentional Communities, an umbrella organization that was revived by latter-day communitarians in 1986. It is now called the Foundation for Intentional Community.

Both Iona in Scotland and Morgan's Fellowship in the United States played significant roles in welcoming Camphill to their respective territories. Karl König developed a friendship with Iona founder George MacLeod, a minister who served a parish "in one of the worst slums of Glasgow," and simultaneously led a group of idealistic clergy and workers who had rebuilt St. Columba's ancient monastery on the island of Iona. The two charismatic community founders met on the day König signed the contract for Camphill estate. MacLeod helped König understand his new cultural context, and within a few weeks König lectured to fifty of Iona's ministers on Steiner's view of the Gospels. In 1942, MacLeod invited König to publish a series of articles in Iona's journal, The Coracle, related to Camphill's practices. König used this opportunity to criticize mainstream medicine for fostering distance between patient and doctor. ${ }^{78}$ Though each man may have hoped to incorporate the other into his community, the two groups eventually went their separate ways in a friendly spirit. ${ }^{79}$ Twenty years later, soon after the founding of Camphill Copake in North America, Arthur Morgan's son Griscom arrived to inform the Camphillers that they were part of an enduring tradition of American communities. He advised them to recruit conscientious objectors as young volunteers, and 
immediately sent his own son John as Copake's first young coworker from the United States. ${ }^{80}$

The relative endurance of communal movements founded in the 1930s, as well as of earlier Pietist and Hutterite communities, suggests that the refugee experience may be an important element in communal success. Refugees rarely have good alternatives to living in community. If they don't speak the language of the surrounding community, they need to maintain close and cooperative connections to the handful of others who do speak their language. Perhaps they are not allowed to seek employment in the larger society. Perhaps they have previously lost all of their individual or family property, and believe that they can achieve more future security by pooling resources cooperatively. Put somewhat crassly, the opportunity cost for living in community is lower for refugees than for other people.

This aspect of the refugee experience adds a nuance to the term intentional community, which was coined in 1945 and is now the most popular designation for a communal movement in the English-speaking world. This phrase implies a distinction from the "traditional community," in which accidents of birth determine who is and is not a member. The members of intentional communities, so the notion goes, are there only through active intentionality-they could be someplace else but have chosen to be here. This is only partially true for refugees and, in Camphill's case, for people with learning difficulties who may have been placed in community through the initiative of parents or social workers. The necessity of the refugee gives a needed ballast to the free-floating intentionality of the volunteer.

Another strength that refugees bring to community is the fact that they often carry a cherished vision of the society they have lost and hope to re-create. Karl König never broke faith with what he regarded as the true spirit of Central Europe, epitomized in the Vienna of his youth. He referred to Camphill as a seed of social renewal, and encouraged Camphillers to preserve aspects of Central European culture regardless of their physical location. One consequence of this is that most Camphills have a distinctive look and feel to them. Visitors have an immediate sense that they have arrived somewhere in particular, and people who spend time in one Camphill will immediately recognize the Camphill spirit when they visit another. Indeed, a common game among English-speaking Camphillers is to try to discern which aspects of Camphill are unique to Camphill, which are rooted in anthroposophy, and which are part of the general culture of the German-speaking world.

A third strength that refugees bring to community is a bit paradoxical: refugees are, almost by definition, people of privilege, and they are able to apply their considerable privileges to the task of building community. To clarify this point, it may help to note the distinction between "refugees" and "internally displaced persons," as defined by the United Nations. An internally displaced person is anyone who loses their home because of violence, war, or persecution. In order to become a refugee, it is not enough just to lose one's home, one must also cross 
an international border. Only then is one eligible for protection by international law. Only a third of displaced people today have crossed a border, and far fewer have made it to a country that does not directly border their country of origin. Those few are privileged in two senses. First, many of them started out with the economic or educational resources that enabled them to travel far distances from the homes where they started. Second, once they arrive at their destination, they have sponsors-governments, nonprofits, and private individuals that are eager to provide them with support.

The founders of Camphill became refugees about a decade before these definitions were formalized, but they enjoyed both sorts of privilege. Most were highly educated professionals, including several doctors, and they were already part of the international support network that is the anthroposophical movement. The vast majority of Central European Jews did not enjoy these advantages and were not able to escape the violence of Nazism. Once they had arrived in the UK, Camphillers quickly found wealthy sponsors who, enthralled by their vision of care for persons with disabilities and by their refugee story, offered large estates as the sites of community. As a consequence, life in Camphill can bring the opportunity to live on a stunning seaside estate, in an elegant castle, or in a rural village that regularly hosts the finest classical musicians from New York City.

To some extent, the strengths that refugees bring to intentional community last only as long as the founding generation. But there are a few ways in which the strengths can persist over multiple generations. First, the refugee generation, through a contribution of its own hard work and the financial gifts of its sponsors, often succeeds in putting a fledgling community on a solid economic footing, ensuring that future communitarians will not have to sacrifice as much to live in community as the founders did. Second, the boundary between the refugee generation and those who come after may be fuzzy, with the share of community members who have been refugees declining very gradually over time. This shelters the community from the abrupt shock that might be experienced with the sudden death of a charismatic founder. The transition can be extended even further if - as was the case for Camphill, and also for Shaker villages, kibbutzim, and many other communities-a significant number of newer members are also refugees, either literally or metaphorically.

Nevertheless, Camphill and its sister communities must also recognize that they cannot rely forever on their refugee roots. A thriving community must eventually be planted in its own soil. Karl König expressed this at the first Whitsun celebration in Kirkton House-even before the group had moved to Camphill Estate-when he told his friends that "we would not live in our new country as foreigners, but would learn to act for its good in the service of the needs of its handicapped children, even if only in a preparatory way." ${ }^{11}$ Yet he never lost his sense of the initial value of the refugee experience. As he announced sixteen years later, at the founding of Botton Village, "the outcasts of today are to be the forerunners of the future." ${ }^{2}$ 
Like Camphill, many of the communal movements founded in the first half of the twentieth century must now choose between the paths of evolving beyond community or creative symbiosis with neighbors. Iona, for example, has downplayed shared living and economic cooperation in order to prioritize its work of holding retreats and seminars about monastic spirituality. In 1992 Koinonia abandoned incomesharing and reorganized as a community development organization in order to deepen its partnership with its African-American neighbors, many of whom supported its mission but did not wish to live communally. But in 2005 it reversed course, reaffirming its original self-definition as an intentional community. ${ }^{83}$

The kibbutz movement, quite famously, has been "evolving beyond community" for at least a generation. Historically, kibbutzim have been legally required to hold all property in common and support their members based on need rather than the work they perform. After an economic crisis in 1985, many kibbutzim began breaking these rules, and in 2005 the Israeli government sanctioned an alternative. The new, "reforming kibbutzim" could pay differential salaries, often coupled with a social safety net. Typically, they also allowed nonmembers to live, work, or study within the kibbutz, and reduced democratic control of business activities. By 2011, more than three-quarters of kibbutzim identified as "reforming."

As Pitzer's theory of developmental communalism might suggest, this change enabled a new flowering of kibbutz ideals. Before the change, most kibbutzim were losing money and losing members. Now, most are stable. It turns out that many people who don't want to join a kibbutz do want to experience the cooperative culture of the kibbutz as employees, renters, or students in the popular kibbutz schools.

The evolution of kibbutzim beyond community is not the whole story, however. For much of the movement's history, it thrived because of the depth of its symbiotic relationship with Israeli society as a whole. Many kibbutzim are actually older than the State of Israel. Many of Israel's founders were kibbutz members. Several kibbutzim were established on desert lands that did not appeal to private settlers. Others chose locations where they faced the hostility of Arab neighbors. This contributed to the military goals of the new nation. By instilling cooperative values in their young people, the kibbutzim produced good soldiers. They also produced good socialists, which benefited Israel's ruling Labor Party. But the kibbutzim began to experience decline when the conservative Likud Party came to power in 1977. Likud enacted neoliberal economic policies that made it harder for the kibbutzim to manage their debts. This illustrates a danger inherent in the path of symbiosis. The more a community relies on its neighbors, the more it is vulnerable to social change.

Today, there is much evidence of new forms of symbiosis that could allow some kibbutzim to retain their distinctively communal features. Several newer kibbutzim are explicitly religious rather than socialist in their ideologies, and these have not experienced the same trend away from communalism. There are also newly founded urban kibbutzim, as well as other intentional communities, that 
seek to rekindle the spark of idealism their founders perceive to be fading at the older kibbutzim. Some of these newer communities explicitly seek to foster harmony between Jews and Arabs, or promote permaculture and other techniques of sustainable agriculture. There is also one specifically anthroposophical kibbutz: Harduf, founded in 1985 in Galilee. Harduf includes a Camphill-style curative home for children with special needs, and in 1979 Kfar Rafael was established as a village community in the desert near Beersheba ${ }^{84}$ In these places, the traditions of Camphill flow together with those of the kibbutzim.

Camphill and the other intentional communities of the 1930s interact today with the many communities formed as a part of the hippie movement of the $1960 \mathrm{~s}$ as well as a host of more recent initiatives. Notable among them is the movement that is most easily compared to Camphill: L'Arche. This international network, consisting mostly of household-scale communities for persons with and without intellectual disabilities, was founded by Jean Vanier in 1964. In 1975 Judith Jones, a Camphill visitor to the original L'Arche community at Trosly in France, "was struck not so much by differences in life-style and ideology, but by what we share in spirit"-and especially by L'Arche's "spirit of prayer and how naturally it is part of life." The same visit took her to Lanzo Del Vasto's Gandhian community in France, also known as L'Arche, and to Taize..$^{85}$ Some of the closest ties between Camphill and L'Arche have developed in Ireland. The Ballytobin community began in the same area and almost simultaneously with the first L'Arche house in Ireland, and the same Catholic curate helped both communities get off the ground. On one occasion, Therese Vanier, the sister of L'Arche's founder, intervened to defend Camphill from criticism by a Catholic bishop. And in 2003 Camphill joined with L'Arche to form a "Lifesharing Alliance" to ensure that the perspectives of lifesharing communities would be reflected in new Irish national standards for programs serving people with disabilities. After twenty years of partnership, Camphill Patrick Lydon reported that it "was a tremendous eye opener" to encounter a movement that was at once so similar and so different: "We had a wonderful experience of 'liking them as much as we liked ourselves.' In fact, we liked them better because we did not know all their dilemmas and failures as well as we knew our own!"86

Probably the two most rapidly growing models of intentional community in the world today are cohousing and ecovillages. Cohousing communities, which emerged in Denmark in 1967, are legally structured as condominium complexes, with individuals or families owning private apartments, but they also include abundant shared spaces with the expectation that residents will participate in common meals, community celebrations, and regular work shifts to maintain the common spaces. Ecovillages have a variety of ownership structures; what they all have in common is a commitment to living in harmony with natural systems and to sharing their own best practices with the larger community of environmentalists. To a degree, these two movements epitomize the contrast between the 
developmental paths of "evolving beyond community" and "creative symbiosis." Cohousing begins with a structure that is similar to that of second- or third-generation communities that have loosened their original communal commitments; it is an attempt to find a balance of individual freedom and cooperation that can be sustained long-term. Ecovillages, meanwhile, actively cultivate symbiosis with the broader environmental movement. They participate in climate change activism and host educational events (such as permaculture courses) intended for people who may not wish to live communally.

At present, the Camphill Movement does not have a deep relationship to either cohousing or ecovillages. Though many Camphillers are aware of these growing impulses, most have not directly visited an ecovillage or cohousing development. Yet several thought leaders in Camphill have suggested that these models have much to contribute to Camphill's future development. Jan Bang, a former Camphiller and kibbutznik who has written books on ecovillages and permaculture, as well as on Camphill, has pointed out that most Camphill places already meet the definition of an ecovillage, even if they do not use the term. ${ }^{87}$ What is more, environmental practices are already one of the major ways that Camphill places build symbiotic ties to their neighbors. They sell organic and biodynamic products at community groceries or through CSAs, they offer neighborhood-based composting services, they send volunteers to civic clean-up events, they host camps and courses on environmental themes, and they provide consultants to help neighbors with clean energy or water treatment projects. These are precisely the activities that ecovillages use to ensure that outsiders will be invested in their futures.

Similarly, some Camphillers see cohousing as an economic and legal paradigm that might help them avoid the pitfalls inherent in their current nonprofit status, and address the concerns of critics who portray them as segregated institutions for people with disabilities. There are two ways this might work. On the one hand, a Camphill could reorganize its residential life on the cohousing model, without changing the mix of residents. Cohousing would give Camphill residents, both those with and without disabilities, more direct democratic control over the community, since cohousing communities are directly governed by their resident owners rather than by "outside" boards of directors. As a system of ownership, cohousing would give residents more freedom to choose the type of residence that suits them best, and more protection against eviction or relocation. It would also sharpen the distinction between residential and work life at Camphill, making it easier for individuals to participate in one but not the other.

More radically, the cohousing model could be used to shift the balance among types of residents in a Camphill. Residences could be marketed to people who neither need specialized support nor wish to provide such support to others. These might be individuals who value Camphill's style of community life but have other professions they are not willing to forego; some of them might be people with disabilities who cherish the ideal of inclusive community but are not eligible for 
funded support services. If, as a result of such recruitment, the share of Camphillers with special support needs declined somewhat, this would make it easier to demonstrate that Camphill is committed to social inclusion rather than segregation, while still allowing residents with intellectual disabilities to forge strong friendship networks with one another if that is their preference. This model was proposed (without specific reference to cohousing) as early as 2007 by Eric Hoyland of Oaklands Park in England, who called it a "third way" distinct from either a stubborn refusal to change or the outright dissolution of village communities. It would create "an environment . . . which would allow an expanded freedom of movement and association for people with learning disabilities who cannot cope with the size and dangers of city life," as well as those "who can cope with life in the city but are nevertheless lonely or isolated or bored." ${ }^{88}$ A variation on this theme has been achieved by the Hertha Living Community, founded in Denmark in 1995 by people with Camphill roots. At Hertha's center are three lifesharing houses that support people with special needs, while the surrounding village consists of cohousing units that may be purchased by anyone interested in village life. ${ }^{89}$ Such synthetic experiments suggest that other intentional communities can be a vital part of the symbiotic web of neighbors who help Camphill maintain its own communal traditions-just as Camphill can make it easier for other communities to follow the path of creative symbiosis.

\section{ENVIRONMENTALISM}

Similar symbiotic possibilities can be found in the environmental movement, including but not limited to its specifically communal dimensions. From the beginning, Camphill had a connection to the environmental movement because it had a connection to anthroposophy. Rudolf Steiner's method of curative education was just one of several practical "initiatives" that he had introduced to his students, and one of the most widely embraced was biodynamic agriculture. The first internationally organized strand of the organic agriculture movement, biodynamics sees each farm as a living organism, refuses to use chemical fertilizers or pesticides, nurtures the soil through composting, companion planting, and alchemically designed "preparations," and channels cosmic influences by planting according to the cycles of the moon and planets. None of the Camphill founders were biodynamic farmers, but all were interested in farming as a healing practice and a source of symbolic correspondences that might illumine their own therapeutic work. It is no accident that the collected writings of Karl König include an entire volume devoted to "social farming" and another to animals.

Much of Camphill's environmental vision crystallized with the founding of Botton Village in 1955. As an adult village, Botton could not appropriately claim that its "work" was care for people with special needs: that would undermine their human dignity as adults with their own vocations of work and service. But 
the Camphillers had long yearned to connect more deeply with Rudolf Steiner's teaching on agriculture, and the sheer extent of the Macmillan estate-which encompassed four distinct farms and 280 acres of farmland-gave everyone an opportunity to develop their capacities for hard work on the land. "Those who are handicapped," explained one founder, "can take their place in the community and can participate in mankind's responsibility towards the earth."90 And the editorial celebrating Botton's founding in Camphill's journal dwelled at length on the ecological crises that the village might help heal: "Earth—how many hundreds of acres slip away yearly, hopelessly eroded by chemical overtreatment! Water-read the daily papers, read of empty reservoirs, receding ground water, polluted rivers and lakes, oil-encrusted oceans!"91

For Karl König, agriculture was an essential practice for Camphill because a living connection to the earth had the potential to draw the community out of the isolation of the refugee experience. "Wherever maltreated, outcast and stunted human existence is to be restored to the holiness of true humanity," he mused, "'villages' arise. ... [But] these are very seldom real villages. They become settlements and are thereby without the curative element and the healing stream of Mother Earth." He envisioned that the practice of farming and gardening would gradually extend Camphill's reach to include "tradesmen, artists and craftsmen" and also to "guide parents in such a way that their children may become people who, out of a civilization in decline, are able to be the seed-bearers of a new culture."92

These ideals were still alive in 1975, when one Camphiller referred to "curative education and agriculture" as the "two pillars" of the village impulse, "stand[ing] in our Villages like the pillars Boas and Jachin in the Temple of Solomon." ${ }^{93}$ Another, reflecting on Botton Village's coming of age at its twenty-first anniversary, stressed that "care for the handicapped" cannot be the primary work of a Camphill village because "the handicapped are workers with us." The villages' mission, therefore, was "to heal the earth," primarily through biodynamics. ${ }^{94}$

The Camphill approach to agriculture also has the potential to challenge widespread assumptions in the broader environmental movement. In a 1975 article, Hartmut von Jeetze, then a farmer at Camphill Copake, challenged the belief that "the cultivation and care of the land" is part of the economic sphere. Highlighting the etymological connection between "culture" and "cultivation," von Jeetze stressed that "the nature of decisions underlying all acts of cultivation is one of individual spiritual activity on the part of those cultivating the land." The misunderstanding of cultivation as economic, von Jeetze went on, was linked to "cheap labour, artificial fertilizers, forced breeding of plants and animals, mechanization" and "the flight of people from the land"-all tragic "compromises" that have been widely adopted because of their "seeming success." The correct path is for communities to recognize their "indebtedness to the land" and allow their farmers "full freedom to administer the land according to methods and principles which are in harmony with the living organism of the farm," without compromises. ${ }^{95}$ In 
part, von Jeetze's claim simply echoed Steiner's threefolding theory, according to which the economic sphere is restricted to the production and trading of physical goods. For Steiner, labor actually belongs to the "rights" sphere, insofar as all workers have a right to basic sustenance, while both land and capital, as sources of new creativity, belong to the cultural sphere. But in the Camphill context, this rather abstract assignment of activities to different spheres becomes concrete, for von Jeetze's argument contains an implicit analogy between agricultural land and persons with disabilities. They too, have suffered in a society that seeks to reduce them to their economic value. Rather than insisting that they perform economically productive work, Camphill claims the freedom to help them express their human potential fully and without compromise.

A significant share of the baby boomers who came to Camphill in the $1960 \mathrm{~s}$ and 1970 os were inspired by the then-blooming environmental movement, or at least affiliated with volunteer organizations with environmental missions. Jonathan Reid, a long-time coworker at Botton Village, for example, first visited the community as part of a two-week work camp sponsored by the British Trust for Conservation Volunteers. "I was with a bunch of other young people and we were digging ditches, planting young trees.... We all camped on the floor of one of the public buildings." His own interest was more in intentional community than in conservation per se, but conservation gave him the entrée into Botton's holistic vision of community. ${ }^{96}$ Another coworker told me how her interest in herbs had steadily developed as she moved from one Camphill to another. In Ireland, she started a herb garden but did not dare trying to dry the herbs in Ireland's moist climate. When she moved to a new Camphill, she was able to take over a herb workshop from a woman who had run it for many years and could mentor her in the art of herb drying. She then moved to a third community, which enthusiastically embraced her proposal to start a herb workshop from scratch. ${ }^{97}$

Coworker Will Browne told me that Camphill had enabled him to pursue a minicareer in wastewater treatment. He first learned of Camphill when he was an architectural student and heard of Camphill's distinctive architectural style. When he visited, he was impressed by everything except the architecture, and soon found a chance to join a community. Almost immediately he was invited to work with a group of Camphillers who were using flowforms-an anthroposophically inspired device that produces a vortex within a stream or fountain - as part of wastewater treatment. "I could combine my architectural interests and training with a whole way of thinking and working which seemed to me to be very exciting. Working with nature." After exploring both reedbed and pond-based systems, the team "found that the ponds were particularly appropriate in the Camphill setting where there is an interest in wanting to integrate more with what is going on, and the educational value of having open water and ponds where you can see the different life forms. And also the aesthetic value is increased with ponds." At Camphill Devon, they even built a water treatment pond right in the middle of the village 
green. "It was very exciting how one uses something like wastewater, that is often viewed as a problem, and uses it as a resource to create something that is aesthetically and educationally valuable."

Will's wastewater work took on a new dimension when he began working in Norway, where "the nature forces ... are much less tamed. . . . You just got a feeling that humans were somehow rather insignificant compared with the power of nature.... The first ponds that we made got washed out by a flood that came the first autumn." He also came to see his effort to "redeem" the pollution caused by humanity as "a kind of Christian act. ... It was during that period that I experienced myself as a Christian. ... That also drew me towards the Camphill setting because there the religious aspect of life was not just something that happened on Sunday in a church. It was something that permeated much more of the life from the morning verses to the celebrating of the Bible Evening." Eventually, Will moved permanently to Vidaråsen, where he teamed up with the local agricultural university to demonstrate that a pond-based system could manage the water of two hundred people even through the Norwegian winter. When I met him, his responsibilities had shifted to the overall management of Vidaråsen, but he maintained a deep personal connection to the ponds he had built. "When it gets too much, I seek refuge down there with the frogs and newts and other animals." ${ }^{98}$

Will's emphasis on the spiritual dimension of Camphill environmentalism was echoed by Ruth Tschannen, who runs the garden at Cascadia in Vancouver. Cascadia is an urban community that does not rely on its garden for a significant share of its food, and she stressed that even the garden crew spends only an hour or two gardening each day. Nevertheless, she said, "I look at the garden as the vessel for everything else. If we believe in the power of the biodynamic preparations, a little garden like this can radiate into the whole city." She then told a story of a Mexican woman who visited Cascadia when they were having an art event in their garden. Since the woman didn't speak English, she asked her daughter to convey a message to the gardener. "I hope you're not offended or think we are strange," the daughter began, but "my mother wants to tell you that she has not seen so many elemental beings in a long time and she wants to say thank you." "Then she looked at me," Ruth continued, "and she could see that this is nothing unusual for me to talk about. And she just started to weep, and she came and she gave me a big hug. ... That's what I'm interested in for the city too."99

Currently, Botton Village is exploring the possibility of creating a "green prescription" initiative, in which people suffering from anxiety, depression, or other mental illnesses would join the community for a brief period in order to find healing in its gardens, workshops, and festivals. "Nature is the perfect doctor for the human being because the human being reacts to nature," explained the employee leading this initiative. "It is like a microcosm. . . . You can say, this is where you put the seed, this is how it grows. If it can flower, it has to die in order to become the seed again. And this is what we are as a human being.... The green 
prescription treats the human being and tries help by engaging his will ... into the activities, with something solid, with matter, where you put your effort into something where you see progression and it doesn't matter if you make a mistake."100

Similarly, Vidaråsen has built a "sensory garden" in addition to its many food-producing gardens and farms. This garden includes a large field of wildflowers, along with a collection of raised beds set at various heights in order to be wheelchair-accessible. As Runa Sophia Evensen Gafni explained, "One main idea was to create a space where people can come from outside and enjoy what is special here. . . . To discover for example what is a flower like in different stages. Or how amazing it is that a butterfly becomes a butterfly out of being a little worm." Some parts of the garden grow herbs that can be made into teas and medicines, while "other areas will be only for your smell or eyes. We will also play with what kind of colors we will plant together. . . . From spring to late autumn, there will always be one area that is in bloom or has a special quality." She also described the garden as a "cathedral in nature ... not restricted to one religion or one belief or one group of people or ethnicity. We are all people and nature is with us and we can meet here."

As I have argued elsewhere, one of Camphill's greatest contributions to the environmental movement is the fact that environmentalism is not its primary focus. For this reason, it excels in bridging environmentalism not only to disability and community, but also to such fields as education and aesthetics. An article in the Camphill Correspondence on beekeeping at Beitenwil in Switzerland aptly illustrates the dynamic. The Camphillers there discovered that their orchard had once had a "bee-house" (a structure accommodating as many as twenty beehives), but that it had burned down. They reached out to their neighbors, who responded with generous donations at the community's first Open Days. This allowed them to purchase an empty bee house and move it onto the site. The local "bee inspector" then alerted them to "an old bee-father who had died and whose bees were in need of a new home." Yet another neighboring beekeeper helped them transport the bees, and by the next Christmas they had one hundred kilograms of honey, and great hopes for a better fruit harvest in the coming season. This touching story of a new Camphill building up its neighborly connections inspired the newsletter editor to add a traditional Sussex round that was popular at Botton: "Bees, bees of Paradise, do the work of Jesus Christ, do the work that no man can."

Given the environmental ideals of many of the young people drawn to Camphill today, it seems likely that symbioses with environmentalism will remain a vital part of Camphill's future, and perhaps with some communities publicly identifying themselves as ecovillages. Though no Camphill has yet taken that step, I got a vivid sense of what such rebranding might mean when I visited Sólheimar Ecovillage in Iceland. Sólheimar is a sister community to Camphill whose founder, Sesselja Sigmundsdottir, was mentored by Ita Wegman around the same time as Karl König. Like many Camphill places, it evolved from a school for children into a 
village for adults, and eventually it renamed itself Sólheimar Ecovillage. Sólheimar is home to many environmental projects. Its geothermally powered greenhouses produce half of the organic tomatoes grown in Iceland, along with a host of other crops. Sólheimar has an energetic tree-planting program, including a self-guided walking trail full of information about the challenge of maintaining biodiversity in Iceland's volcanic environment. It currently does not have livestock, apart from chickens, but its director is trained in biodynamic agriculture and eager to expand the community's farming activity. Much of the community's life centers on Sesselja Hus, which is set up as a center for environmental education featuring interactive exhibits on sustainable power and Icelandic ecosystems.

Most of these activities have parallels within Camphill, such as Botton Village's tree planting program and Clanabogan's promotion of biomass heating. The big difference, though, is that Sólheimar's self-identification has put it on the map for national and international environmental tourism. Several community buildings are set up to host visitors, retreat-center style, and these are regularly rented to yoga groups, art therapy organizations, and the like. "Groups like to come here," one leader explained, "because it is quiet, you live in a nice environment, you can have healthy food, you can breathe healthy air." ${ }^{103}$ While most Camphills are reluctant to welcome young coworkers for periods of less than a year, Sólheimar regularly plays host to groups of students who come for a semester, a summer, or a visit of just a few weeks, and most of these groups come under the auspices of environmental studies. As an ecovillage, in short, Sólheimar has greatly expanded the range of neighbors who are invested in its future as a community.

\section{SOCIAL CARE IN AN AGE OF AUSTERITY}

When Camphill began in 1939, the founders spent little time interacting with the social care authorities. In Britain, as throughout the West, many people with intellectual disabilities were housed in government-funded institutions, but the de facto mission of those institutions was to keep such persons out of the consciousness of policymakers. Even before arriving in Scotland, Karl König was committed to finding an alternative. In his proposal for a curative institute-first submitted to the government of Ireland-he faulted the existing institutions for expecting persons with disabilities "to wait tardily for a miserable death." A better approach, he wrote, was to recognize that "abnormal people . . . have come into the world in order that the works of God may become manifest in them.... They all deserve that they would find a community in which they would be able to live and to take up the tasks and the work which is within their abilities." König assumed that persons with intellectual disabilities would not be able to compete within the mainstream job market, and he was wary of supported employment schemes that might harm nondisabled workers by making the products of the disabled more competitive. But he believed that special communities for persons with disabilities could be 
self-sustaining, because they would "complement one another like the blind and lame and ... form in their togetherness a whole and fully adequate community," in which "the mark of inferiority" would be removed from their foreheads. ${ }^{104}$

Camphill maintained its critical attitude toward the large society's approach to disability, even as it attracted the support of parents and social workers. At the founding of Botton Village, König incorporated his critique of intelligence testing into a dystopian vision of a coming "managerial society" in which "the manager with his special 'I.Q.' will lead the less intelligent roboters." time, Thomas Weihs commented ironically on the incoherence and contradiction of Britain's Mental Deficiency Act of 1913, which identified the categories of people who could be forcibly institutionalized. But he also noted that one of its "positive openings" was the implication that "mental deficiency is not a diagnosis of an individual condition, but that it is a term describing a social phenomenon, that is-a phenomenon of relationship between the community and the individual." Drawing on this insight into what we would now call the "social model of disability," Weihs concluded that that the proper response to mental deficiency should be "to find new social forms, new forms of community living that will accept the individual, integral personality in such a way that the developmental 'otherness' becomes variety instead of abnormality, and that diversity instead of uniformity is the foundation of social life." ${ }^{106}$

By that time, new ideas were beginning to percolate among the psychologists, and the pace of change in disability policy has not abated since. ${ }^{107}$ In 1956 Karl König reported to the other Camphillers about a series of experiments conducted by "progressive" mental hospitals, in which patients were given more attractive accommodations and more opportunities to read, do handicrafts, and perform household tasks, and proved to be far more capable than their caregivers imagined. In 1958, Britain's National Society for Mentally Handicapped Children (later known as Mencap) conducted an experiment that compared the experiences of institutionalized children with those placed in familylike settings and offered ordinary schooling. The latter group did better, giving rise to campaigns for deinstitutionalization. König observed that such successes depended partly on the enthusiasm of the participants, and warned that Camphill was also vulnerable to deterioration as "the original impulse dies down and ... human relationships go to sleep." 108

Additional research on the human costs of institutionalization justified significant changes in both the policy and philosophy of social care. In 1959 Britain's new Mental Health Act replaced the Mental Deficiency Act, bringing a new emphasis on the value of providing care "in the community" rather than in specialized institutions. In 1968, the Seebohm Report, commissioned three years earlier to review British social services, recommended policies that would shift most care for persons with disabilities into homes and small scale facilities immersed in residential neighborhoods. It also urged the reduction of "the rigid distinction between the 
givers and the takers of social services and the stigma which being a client has often involved." $1{ }^{\circ}$ This vision was echoed in a British white paper entitled "Better Services for the Mentally Handicapped" and in the proceedings of the 1973 convention of the American Association on Mental Deficiency. By the 1980s, Mencap was offering community-based housing for persons with disabilities, and in 1995 Britain's Disability Discrimination Act was passed. ${ }^{10}$

In 1969 the Swedish psychologist Bengt Nirje encapsulated the theory underlying these policy changes with his notion of "normalization." This is the idea that people are devalued when they are placed in roles or situations that differ from the cultural norm, as is the case in institutions that segregate persons with disabilities and treat them exclusively as recipients of care. The antidote, logically, is to ensure that persons with disabilities (and, indeed, members of all stigmatized groups) have access to all of the resources, life circumstances, and social roles available in the larger society. This theory underlay the rapid embrace of deinstitutionalization in Scandinavia in the 1970s. In the United States it was adopted by Wolf Wolfensberger, who guided many deinstitutionalization programs from his research center at Syracuse University. Wolfensberger eventually preferred the term social role valorization, which avoided the misleading assumption that there is universal definition of "normality." His point was that the best way to protect people from dehumanization is to place them in roles that are valued in their specific cultural context. Wolfensberger also believed that government funding exacerbated institutional dynamics, and perhaps for this reason he maintained warm ties to both L'Arche and Camphill. He got to know Helen Zipperlen and other residents of Camphill Village Kimberton Hills during the campaign to shut down the massive Pennhurst hospital, located not far from Camphill. His ideas shaped Kimberton Hills's decision (somewhat rare in the larger Camphill context) to refuse licensure and government funding; his colleague John O'Brien also supported Zipperlen's "Safeguards" project, which identified strategies for ensuring safety in unlicensed communities. ${ }^{.11}$

Other Camphillers responded to normalization theory with more caution. In a newsletter editorial that mostly praised the new emphasis on the integration of persons with disabilities into the larger society, Richard Poole warned that "like all good things, integration carries its shadow with it." He reminded Camphillers that "the all-powerful state is in the saddle behind many campaigns for "normalisation."112 Jeff Balls sounded a similar warning in a reflection on the multiple meanings of "integration." Drawing on Charles Reich's New Left critique of the "American corporate state," Balls suggested that mainstream society caused disintegration by forcing people to act as both disciplined producers and hedonistic consumers. Balls concluded that "if, on the one hand, we can help people, handicapped or otherwise, to become integrated, to gain integrity, and on the other hand work towards an integrated society, a society with integrity, then the problems associated with integrating people into society will be very much less 
formidable." ${ }^{113}$ Similarly, Botton Village founder Peter Roth acknowledged that the call for integration was an attempt to honor "the dignity of the human being," but warned against simply integrating into a "normality" that "is inextricably permeated by inhumanity." True integration required an active commitment on the part of persons without disabilities to join their handicapped neighbors in the work of "running coffee houses, restaurants, shops in town, farms, gardens, forests in the country."114 These arguments ran parallel to the criticisms of normalization voiced by disability studies pioneer Michael Oliver around the same time, yet as far as I can determine Oliver and the Camphillers were unaware of one another. ${ }^{15}$

By the middle of the 1970s, it was clear that the Seebohm Report's vision of care in the community would not be fully realized (in Britain or in other societies with similar policy aspirations), simply because appropriate day programs were not being created rapidly enough to accommodate the thousands of people being discharged from residential facilities. Instead of becoming part of the larger society, many people with disabilities were "now totally isolated, lonely and almost forgotten." The Camphill town community at Stourbridge responded by creating a "Community Care Club" where people gathered to do crafts together, as well as playing games, singing, watching films, and holding conversations. ${ }^{116}$

In 1975, a government commission in Norway called for persons with disabilities to be moved from residential to day programs. Camphill, as well as other residential programs, was "caught between the pressure to bring the handicapped out into the 'normalcy' of society, and the grim reality of a 'care' programme that has laid little foundation for integration." But the Norwegian Camphills were well placed to meet this challenge, for they had already begun promoting "a conscious 'flow' between village and surrounding neighbourhood." They also had many allies, for thousands of Norwegian school children had raised money for Camphill by selling candles. In this context, government officials saw Camphill as "one guide-post in an otherwise uncharted landscape." ${ }^{117}$ Ultimately, Camphill received its own special line item in the national budget even as older institutions were shut down. Camphill in Norway still benefits from this arrangement, operating with greater freedom than is possible in virtually any other country. But in a sense the Norwegian story reveals the seed of Camphill's later struggle in the UK and elsewhere. Precisely because Camphill offered such a high standard of care in the 1970s, Camphillers did not participate fully in the new conversation about normalization. They engaged it intellectually, but then fell back on the superiority of their own practices, rather than struggling deeply to connect the best insights of their traditions with the best insights of the new approach.

The 1970 conversation about normalization also provoked Camphillers to engage fundamental questions about the nature of intentional community: Was Camphill a utopian alternative to the rest of society or a renewing impulse within that society? When Camphillers at Hogganvik in Norway asked, "Do we really want to encourage villagers to go back into society, if what we want to create in 
the village is an alternative to this society?" they realized they had to ask, "Is the Village an aim in itself or is it a station on the way back to society? If the Village is a lasting alternative system, how should we then build a bridge into society at large?" Such questions were given extra poignancy by the fact that Camphill had not been consistently welcomed by their local community; only after two and a half years of deliberate outreach did they persuade a villager from the local area to join Hogganvik. But once that happened, they were in a position to discuss "another type of integration": taking action to preserve a declining rural community by taking on local enterprises, such as a bakery and a laundry, that were closing down. ${ }^{118}$

Social care policy took a new turn in Great Britain with the election of Margaret Thatcher as prime minister in 1979. Thatcher turned back four decades of expanding governmental services, promoting private enterprise and free trade as panaceas for all that ailed humanity. Her politics of austerity spread to the United States during the Reagan years, and to a lesser degree infected most of the other nations where Camphill operates. Ever since, social care policy in the West has had two faces. On the one hand, policymakers seek to promote the human dignity and social inclusion of persons with disabilities, and they have relied heavily on inspections and regulations to achieve this goal. On the other hand, they have been asked to spend ever less money on the task.

Camphillers, for the most part, oppose Thatcherite politics of austerity but are ambivalent about the trend toward greater regulation of social care services. They wish to honor human dignity and to promote full inclusion within their communities and in the larger society, but are not convinced that inspections and regulations are paths to this goal. "People say yes we want it person-centered and the person is important," explained one coworker in Ireland, after questioning the need for "a very detailed and intellectualized style of record keeping." They also struggle to discern which policies are genuinely motivated by a commitment to human dignity and which are the fruits of austerity. Two buzzwords in twentieth-first-century social care are personalization (also known as self-directed support or individualization) and care in the community. Personalization refers to the goal of allowing each person with special needs to choose a unique package of care from a wide variety of choices, with residential and workplace services ideally being offered by different providers. "Care in the community" assumes that, since all people have a right to be fully included in mainstream society, all forms of care should be provided in settings that are as little removed from the rest of society as possible. The idealism underlying both approaches is self-evident, yet both hold out an illusory promise of reducing the overall cost of social care. Self-directed support encourages price competition among care providers, while care in the community hopes to replace residential care facilities and sheltered workshops with private homes and paid employment. In such a compartmentalized system, it is not clear that anyone is responsible for ensuring the holistic wellbeing of persons with disabilities. 
By undermining the idealism inherent in aspirations toward personalization and care in the community, austerity sometimes made it easier for Camphillers to avoid the critical self-examination that those ideals might have provoked. If Camphill life in practice was superior to "care in community" as practiced under conditions of austerity, why should Camphillers rethink their own approach? It soon became common for Camphillers to draw ironic contrasts between "care in community" and their own more authentic vision of community life. At the opening of a new Camphill farm in 1993, Peter Bateson promised that it would provide "not 'care in the community' but life in community, an active working, social and cultural life, in a setting and in circumstances which make possible real mutual understanding and mutual support." ${ }^{120}$ Two years later, the founders of Camphill Cherry Orchards promised to provide "caring communities" as an antidote to "the failure of the 'care in the community' policy." ${ }^{121}$ Such rhetoric made sense to Camphill insiders who understood that the criticism was directed at austerity rather than inclusion, but it did little to invite dialogue with sincere advocates for "care in the community."

One positive side effect of the politics of austerity is that many Camphill communities have forged new partnerships in the hopes of preserving the integrity of their work. In about the year 2000, the Irish Camphills negotiated a new agreement, called "Enhancing the Partnership," with the government bodies that funded their work. This involved a good bit of anxiety, as Camphillers worried "that the State, so tied to financial considerations, so transparently materialist, is incapable of more than a short-term commitment because its primary allegiance is to public opinion." So they convened a series of conversations with friends involved in other charities, in government, and in education, to articulate the components of authentic partnership: equality, trust, "creative tension between diversity and unity," and a "will to enhance and empower the Other." Reflecting on these conversations, participant Patrick Lydon articulated a core dilemma. On the one hand, "we know that to move on we must find our place in the mainstream, in the market place of society." On the other, "there is a genuine and justified fear of being overwhelmed by the pervasive force of the market place." This dilemma is not unique to Camphill: it is the challenge of every organization that seeks to preserve non-market-based ideals within a neoliberal society. ${ }^{122}$

The politics of austerity has also challenged the Camphill practices of incomesharing and lifesharing. When unpaid volunteers maintain comfortable middleclass lifestyles, it is easy to ask questions about whether incomesharing is simply an elaborate tax dodge. As Thatcherite policies of austerity reduced funding for social care in the UK, social care authorities often demanded that Camphills link each line item in their budgets to care for persons with special needs. It might be acceptable to pay a high salary to a highly credentialed specialist like a doctor, but unacceptable to pay the school fees of the children of farmer with minimal care 
responsibilities. From the perspective of these authorities, lifesharing is suspect because it is difficult to disentangle money spent for the household needs of people receiving care from money spent for the needs of those providing care. Lifesharing can also make it difficult to respond to accusations of sexual or physical abuse. Ordinarily, the person accused of abuse would be removed during the investigation of the accusations, but when this person and their family are part of a common household, this disrupts the lives of everyone living there.

Especially in Great Britain, questions about incomesharing and lifesharing have accompanied an overall increase in regulative oversight. Intensive inspection of schools serving children with learning difficulties began in the 1980s, and similar inspections came to the adult communities in the 1990s. The governmental bodies charged with overseeing care services for persons with intellectual disabilities have changed multiple times since the beginning of the century. In England, the Commission for Social Care Inspection was created in April 2004 to consolidate the work of several distinct regulatory bodies, but just three years later the regulation of services for children was moved to a different body, and in 2009 the Commission for Social Care was replaced with a new Care Quality Commission. The Scottish Care Commission began in 2002 and was consolidated with other organizations to form the Care Inspectorate in 2011. In the Republic of Ireland, the Health Information and Quality Authority was established in 2007, with a mandate to greatly expand oversight of social care facilities in the wake of several well-publicized scandals at a variety of care institutions. ${ }^{123}$

By the time I began visiting Camphill places, the pace of change had accelerated to the point that many Camphillers viewed changes in the social care establishment as the most significant challenge for Camphill's future. "It is changing dramatically," said one person who, as a state employee charged with overseeing Camphill's regulatory compliance, was partly responsible for the changes. Because the authorities were no longer willing to send children who could be educated in the mainstream schools, the only children coming to Camphill were the ones "who can't be educated in school and the situation at home has broken down and they have extremely challenging behaviors." Young coworkers were not always able to manage those behaviors, and so they had to hire "very specifically trained staff ... which changes the whole ethos of the community." What's more, regulations both small and large were undermining lifesharing: "The children can't all sleep in one room. You have to take the temperatures of the fridges. You have to make sure that there are menus on the wall. You have to make sure that your doors are locked. You have to make sure that these children are kept safe. You have to let us know if anything happens to these children." The stress of following so many rules, she concludes, was causing "a lot of disillusionment in the community".124 A coworker who had come to that community from a Camphill in England described similar changes with a sharper edge. 
Everything had to start being documented. Some of it definitely very important, like medication. ... But towards the end of the thirty years in Devon, it became so that you couldn't ask the adults to do anything. You could encourage them. But you couldn't demand of them to do anything. And that was a great shame because a lot of people have their weaknesses in the realm of the will forces. And yet if you can encourage them and support them, they are so happy when they have achieved. They have baked a batch of bread or they have made yogurt or they have done their work in the garden like everyone else. We were a real working community. But towards the end it was becoming more a babysitting service. ${ }^{125}$

Angelika Monteux told me that the pace of change in Scotland had been greatest at the turn of the century, when adjusting to the new regulations meant learning "to use a different language." This wasn't wholly bad though, she said: "I realized that . . Camphill isn't the only place for children with special needs. There are other people that have good ideas as well and one can work together. That was a big eye-opener." ${ }^{126}$ Her experience was typical of many Camphillers in Scotland. "Some of the early inspections went quite well," explained a Camphill Scotland staffperson, "and some of them didn't go so well. What was targeted was things like health and safety. A kind of lax approach to electricity and water and things being left lying around and so on." Many of the inspectors were brand new to the work and focused on trivial things, and some Camphillers reacted by refusing to cooperate with them. But a larger number of Camphill's leaders, said Neil Henery, "really took on the challenge of working with the Care Commission" by implementing recommendations in ways that would improve Camphill. ${ }^{127}$ One of those young leaders, Tom Marx, reported that he "had heard it reported from all quarters that the Care Inspectorate are terrible," so much so that he had to ask an older coworker to step out during an inspection. Once he could engage the inspector directly, "I realized that the bloke actually wanted to help us. But he didn't have the language that we were using and we didn't have the language that he was using. . . . These guys who were inspecting us actually liked what we were doing and they were keen to point us in the right direction." "128 By 2013, leaders in Camphill Scotland were cautiously optimistic that they had "cracked the Care Inspectorate issues." This was possible both because of the creativity of the Camphillers and because Scotland is a small polity with a deep and well-known Camphill history.

Some small Camphill places have been able to create similar niches for themselves. When Camphill Cherry Orchards became a registered care home for persons with mental illness, explained Stephen Sands, they "were immediately under a very stringent series of regulations, some of which were annoying and practical like size of rooms and sinks, placement of fire extinguishers, and that kind of thing. Others were, we felt, very sensible . . not something to be pushed against, but rather to be developed out of our own ethos and lifestyle." Because Cherry Orchards was moving into the (for Camphill) new field of mental 
health, they were committed to cultivating good relationships with the psychiatric establishment, recognizing that "there were psychiatrists out there who were [also] frustrated and being disempowered by the system as it was." They "wanted to have a cooperative gesture whenever possible. And be very clear about where we stood, but be willing to actually listen to what others wanted to say to us."129

At Camphill Glencraig in Northern Ireland, I heard a paradoxical story about government inspections. Because Glencraig includes both a school for children and a village for adults, it fits awkwardly into government categories and has experienced a confusing mix of intensive inspection at some times and benign neglect at others. Overall, Vincent Reynolds reported, "the weaker we've become, I've experienced more support coming from the authorities." When inspections began, they were a strong and cohesive community, and "maybe there was a certain arrogance that we were going to do it ourselves." By the time of their 2007 inspection, on the other hand, school enrollment was declining and there was a real question of whether it would survive. The inspectors responded with a strong affirmation "that there is a need for Glencraig. ... For the children who were here, there wouldn't be another place for them." A survey of other special schools identified sixty children whose schools were "struggling to meet their needs," and who might be well served by Glencraig. ${ }^{130}$

Changes in social care regulation have been much more devastating for many Camphills in England. Some of these communities received such negative inspection reports that local authorities refused to place any new persons in their care. These inspections came at a time when many communities were already struggling to recruit lifesharing coworkers. The board of the Camphill Village Trust responded by curtailing its practice of both incomesharing and lifesharing. It first transitioned most of its smaller places to an employee-only model, then in 2015 implemented this policy across all its constituent communities, including those that still had vigorous groups of long-time coworkers. I shall discuss the consequences of this conflict later.

In several cases, Camphill places have been forced to abandon lifesharing in the wake of allegations of physical or sexual abuse, or after failing to develop a consistent plan for preventing abuse. This is a source of much soul searching for Camphillers. On the one hand, they are keenly aware that abuse has taken place in Camphill, and that Camphill as a whole could do a better job of safeguarding against it. On the other hand, many Camphillers worry that bureaucratic responses are not guaranteed to succeed, and that they can also cause much human damage. Many tell anecdotes of coworkers who were removed from communities because of allegations that were never substantiated. Diedra Heitzman noted that the state of New Jersey, as one example, requires coworkers to sign a statement agreeing to report any incidents of abuse. It also defines "willfully ignoring" someone as a form of abuse. But what, she asked, if someone has a habit of asking the same question dozens of times? Is refusing to answer for the forty-fifth time willful ignoring? 
"What if a young person comes in and sees something they don't understand and chooses to call the state of New Jersey?" "131

The changes in social care regulation have contributed greatly to the workload of Camphill coworkers, who spend more time filling out paperwork and less time interacting directly with the people with whom they live. "Evidence, that is what they are looking for," explained one coworker in Scotland. "Each year we write an eighty-page document and provide another full folder with evidence of how we do things. . . . It is a lot of work, to be honest." ${ }_{132}$ Another cost of the increased workload is a loss of time available for other activities. One long-time Camphiller suggested that people simply have less time for anthroposophical spiritual practices, seasonal festivals, and performing arts. "Twenty or even fifteen years ago it was something which was almost taken for granted. Now it requires an ever greater effort to find a time for say putting on rehearsals and freeing people from other activities." 133

The notion of "personalization" brings other challenges to Camphill. Increasingly, policymakers see persons with learning difficulties as citizens with specific rights, among them the right to purchase their services from a menu of choices, even if that means splitting up the services that Camphill once provided in a comprehensive way. The logic of citizenship-which many Camphillers would endorse-is thus tangled up with a logic of consumerism that they are inclined to resist. "Personalization is a way of trying to help services attend much more closely to the needs, wishes, wants, preferences of individuals," explained Camphill Scotland's director, Neil Henery. "Camphill because of its traditions has lots of strengths in that way already," but they are not always visible to people who have "preconceptions" about Camphill and its worldview. Moreover, under personalization "service users are almost treated as if they were customers, so that the customer with the widest proactive choice is the happiest customer." 134 Another person said that "with the Care Inspectorate, the rights of the individual are all important. ... If the person wants it, the Care Inspectorate will come in and [insist that] they've got a right to it. I remember, we had what we viewed as a wonderful menu with biodynamic food, everything was fresh ... grown ourselves in our own fields, our own potatoes, our own carrots. .. . The Care Inspectorate came in and said, where's the choice of food on the menu. . . . I said, we are trying to emulate family life. How many families have a menu?" 135

Some Camphillers view these trends through the lens of Rudolf Steiner's account of the two demonic figures, Lucifer and Ahriman, who vie for power over humanity. Lucifer is the demon of excessive spirituality who tempts us to ungrounded idealism; Ahriman is his materialistic rival who would bind us to the physical world; and Christ's role is to chart a balanced path in between. In the context of this paradigm, bureaucracy is "Ahrimanic" - and, in my experience, Camphillers spend more time worrying about Ahriman than about Lucifer. According to the regulators, groused one Camphiller, "a room has to be so many square meters and 
you have to have a sign on the door to the bathroom, even though Johnny and George know where the bathroom is. .. But then you take away agency from them, because they know where the bathroom is." ${ }^{136}$ In Ireland, Tobias Pedersen observed that increasing regulation "is good because it makes us look at our own practices, and we can improve." But "we can also go over the top with so many policies and procedures that the actual living together and working together is not there anymore." When "the Ahriman factor comes in," he went on, "everything has to fit into a neat box where you can either put a tick or cross on it." Things may be neat and hygienic, with "incredible policies ... but is the community any happier? ... I wouldn't say [it is] unhappy, but the quality is gone. The spontaneity. Because you can't have a policy for spontaneity. And I suppose the friendship, love, spiritualism, doesn't have a box. You can't box spiritualism." ${ }^{137}$

When Camphillers describe regulations as "Ahrimanic," they are not necessarily rejecting them. The cardinal anthroposophical value is balance, and the person who complained about bathroom signs also stressed that Ahriman and Lucifer are not intrinsically "bad" but simply "forces that are around us" that we should strive to understand and "work with." ${ }_{138}$ Another Camphiller in Ireland said that she had left the UK to escape the bureaucracy, "but it was an illusion that it wasn't coming here." She came to see her task as "keeping the flame alight," even if just barely, until the time when Camphill's work "really shines" again. ${ }^{139}$ Inspections and regulations, one coworker told me, "have raised a lot of awareness. Of course it has made us improve in a lot of things." At the same time, they have brought "an extremely intellectual approach to people with learning disabilities, which is not the initial impulse of Camphill." You "medicalize the person" when you have to write up detailed plans about every aspect of their life, and "we have had to work very hard to counterbalance that with humanity and with just living together. Because the key ethos of Camphill is living together as equals with people, and not seeing them as the clients that we are managing and supporting."'

Some identify ways in which social care has moved in Camphill's direction. "The whole view of anthroposophy is to help us become more truly human," explained one coworker. The authorities support this when they insist on "reflective work, training opportunities and so on. ... [Care workers] are being encouraged to grow in their work and in their tasks. ... In Camphill, that one always has the opportunity to do many different tasks and develop many different possibilities in oneself." ${ }^{141}$ Another person said the Care Inspectorate was right to challenge Camphill to think more deeply about individual rights, both for villagers and for staff. "I think that's in keeping with what Rudolf Steiner would have wanted. Rudolf Steiner wasn't somebody who imposed anthroposophy on people. He said it has to come from the individuals really".142

The changes in social care have forced Camphill to think more consciously about its core identity. Is it, at heart, a network of schools and social care facilities that uses intentional community as a tool to provide the best possible care to 
persons with special needs? Or is at an intentional community movement that is especially committed to the full inclusion of all persons regardless of ability? For eighty years Camphill places have often defined themselves in both ways, depending on the context. A few have made definitive choices one way or the other: Camphill Village Kimberton Hills, for example, refuses to be licensed as a social care facility to underscore its identity as a community, while the Camphill Village Trust has abandoned incomesharing and lifesharing in order to accommodate the preferences of the social care establishment. At most other places, it is a lively topic of conversation. At Camphill School Aberdeen, for example, Jonny Mallam-Clarke told me that his house community regularly debated the issue, with different people taking different views. "I say, I live in an intentional community. It is also a school for children with special needs. Whereas some people would say, I work in a boarding school for children with special needs." He was sure Camphill's founders were on his side: "It was founded first and foremost as a community. . . . It was a community whose focus was work with children with special needs, but as one of the senior coworkers said to me, it could equally have been making shoes." ${ }^{143}$

The key choice, many Camphillers say, is between Camphill as "service provider" and Camphill as community. "The world wants to buy things, services, and we have to sell it," explained Christoph Hanni. To do that, you have "to be a good professional." But "it is not professionalism you need, you need to be you. When you meet, as you are, the other person, then something can happen. That is what Camphill is for." ${ }^{144}$ A government employee who has worked hard to help Camphill coworkers improve their relationships with social care authorities said that she often tells them that "if they wanted to continue to live here, then they had to turn more from being an intentional community to being a service provider. Because that is what the outside governing bodies were saying to them. You are a service provider." ${ }^{45}$ Another Camphiller suggested that Camphill's identity as a service provider was a useful "disguise," but not the true spiritual identity of the movement. "Disguise not in the sense of not being true," she clarified. "We do provide services to each other." So long as the deeper spiritual "idea is living, shining within me," it is fine to identify as a service provider. But she warned against confusing the disguise with the essence. ${ }^{146}$

A long-time coworker at Botton Village, Jonathan Reid, told me that his community confronted the choice between identifying as a community or a service provider in the 1990s, when their local authority asked them directly, "What is your core activity?" The person asking the question, he recalled, assumed that there was one right answer: "The answer should be social care provision, because you are actually asking for quite a lot of money to do that." But Jonathan had a different answer, inspired by Botton founder Peter Roth: "I felt very strongly that our community activity is not to have a core. . . Y You don't create something and say, this is it. You are constantly creating an empty space. That is why Peter was ... wildly enthusiastic about encouraging peripheral activities. Great idea to have 
a Waldorf school. Fantastic idea to have a eurythmy school. All these peripheral things which have been repeatedly questioned by the social care [authorities]... . feed back into the central space as unquantifiable richness. For life, for everybody's life. And especially for the life of people with a learning disability."147

Many refuse to blame the government for the changes in Camphill life, pointing out that Camphill could restore a more communal identity by refusing government funding. "We have lost our freedom," asserted Simon Beckett. "And that is our own doing. We still can live in the free spiritual life, as individuals carrying our own quality of life that each human being brings into the world with their karma, but we've lost the freedom to do that because we have become overburdened by the demands that the state puts upon us. And it begins with taking their money." ${ }^{148}$ Christoph Hanni added, "We like to preserve our comforts and we kill Camphill by it." 149 Tom Marx offered a milder self-criticism, suggesting that Camphill's difficulties in the face of the social care authorities stemmed from a lack of confidence. Instead of responding to inspections with fear, "we should offer alternatives. We are being asked by a Care Inspectorate who know nothing about who we are. And of course they are going to apply conventional models to us because that is what they know. It doesn't mean that they are unwilling to take what we know if we can show that it fulfills the regulation." 150

Some Camphillers who adamantly oppose the bureaucratization of their movement also hold out hope that Camphill may be on the cusp of a new developmental transition, in which it finally realizes its original vision of creating a community in which people of all abilities are truly equal. "As long as you are moving," mused one Camphiller, "even if it is downhill . . . and even if it is going into the muck, as long as you've got the speed behind it . . . the momentum can be the very thing that actually will lift you out again." You will come "out very different," but that is simply a challenge not to judge too quickly, lest "you actually become a bigger problem than the very thing you are criticizing." ${ }_{151}$ "We've been hiding very much under the old forms," said a coworker at Glencraig. But if they were to follow the logic of individualization all the way, they might be able to "bring community back to the forefront." A community that renounced the comforts of being a service provider would need to ask "how one supports each other" and "how does one actually generate the income one would need to live." But if Camphillers were to ask these honestly, they might "muster the last few ounces of chance to actually climb onto the next stage." 152

\section{DISABILITY RIGHTS}

Camphill's complex relationship with the social care establishment has a third partner: advocacy on behalf of persons with disabilities that stems not from the duties of caregivers but from the lived experiences of persons with disabilities themselves. Contemporary disability rights activism, as well as much scholarship in disability 
studies, centers on two claims that are encapsulated in pithy slogans. First, activists argue that persons with disabilities are harmed more by the structures and attitudes of society than by the physical symptoms of disability. Ours is, they say, a disabling society. Second, they insist that social change requires that persons with disabilities be democratically empowered to shape all the policies and institutions that in turn shape their lives. Here the rallying cry is, nothing about us without us. Both phrases emerged from the mobilization of people with physical disabilities in the 1970s, with Great Britain's Union of the Physically Impaired against Segregation playing a central role in crystallizing the "social model of disability," which distinguishes physical impairment from the harm caused by a disabling society. ${ }^{153}$

Camphillers have not always used the phrase disabling society, but that idea has been integral to the movement ever since Karl König identified the emphasis on measurable intelligence as one of the three "great errors." ${ }^{54}$ Such an emphasis, he clearly saw, prevents people with intellectual disabilities from sharing their unique gifts, and serves no useful purpose for the rest of society. The deep attachment that many nondisabled Camphillers feel for the movement stems from their realization that a disabling society ultimately harms everyone. A community built around the distinct needs of persons with intellectual disabilities, by contrast, is likely to provide everyone with the support we need to become our best selves.

Nevertheless, there is a significant difference between Camphill's response to the fact of a disabling society and that of most activists. While activists-especially those who framed such legislative remedies as the Americans with Disabilities Act (1990) and the British Disability Discrimination Act (1995) - often focus on removing specific societal obstacles to inclusion, Camphillers seek to build inclusive communities from the ground up. The distinction parallels the difference between the utopian socialist communities of the nineteenth century and the work of socialists who opted for union organizing, electoral politics, or violent revolution. As was the case for the different brands of socialists, there is much potential for competition and misunderstanding. Camphill can be faulted for serving only a small, often privileged subset of persons with disabilities, thus diverting energies that would better be directed toward society-wide transformation. As early as the 1970s, Camphill faced significant criticism from those who described Camphill places as "pleasant asylums" imposing a "benevolent segregation" on persons who should be empowered to integrate with the social mainstream. ${ }^{155}$ In 2004 the head of the British Council of Disabled People argued that while village-scale communities correctly "acknowledge that the rest of society doesn't yet include people with learning disabilities," their response is not to challenge that reality but to "go elsewhere, so as not to bother anybody."156 Conversely, Camphill could fault more mainstream activists for accepting piecemeal and partial solutions that leave many people with special needs feeling lonely and isolated. But there is also a potential for a mutually beneficial dialogue. To the extent that Camphill has achieved a form of community life that is not disabling and that is genuinely open to its neighbors, 
activists might use it as a model for larger-scale proposals. And to the extent that Camphill's reality still falls short of its aspiration, it could learn from the critical perspectives of activists at the cutting edge.

There are also important resonances between Camphill's vision and the insights of disability studies scholars who have sought to nuance the widely influential social model of disability. Many who accept the distinction between "impairment" and "disablement" nevertheless insist that the embodied experience of impairment can be as significant as socially imposed structures of disablement. ${ }^{157}$ Taking a cue from queer theory, some of these scholars suggest that it is not enough to remove barriers to inclusion; the larger goal is to "reverse the hegemony of the normal" and create space for the full expression of embodied difference and "new crip/ queer subjectivities."158 Camphill communities are adept at this sort of space making because they are designed from the ground up to foster the distinctive rhythms and lifeways of persons with learning difficulties. Scholars working at the intersection of queer studies and feminism also stress that "disability-like gender-is a concept that pervades all aspects of culture," extending far beyond the individual experiences of persons with disabilities. ${ }^{159}$ As complex intentional communities, Camphill places are able to bring a disability lens to their structuring of workplaces, homelife, and cultural activities. Camphill caregivers also draw inspiration from the work of disability scholars who are themselves parents of children with intellectual disabilities. Recognizing that no individual is an island, these scholars highlight the ways impairment and disablement impact the lives of families, friendship networks, and communities, and call for a culture of mutual caregiving akin to what is already happening at Camphill. ${ }^{160}$

The second slogan of disability rights activism, "nothing about us without us," expresses a complex and necessary challenge for Camphill. It is a necessary challenge because Camphill has not yet evolved structures that make people of all abilities truly equal participants in the deliberative processes that shape Camphill life. It is true that people with learning difficulties exert much indirect influence on Camphill life: coworkers and employees are continually observing the behavior of their companions and making adjustments intended solely to foster their wellbeing. This rarely happens in mainstream society. Yet this is not quite the point of the slogan. In the language of social threefolding, one might argue that Camphill's work with persons with disabilities has been exemplary in both the economic and cultural spheres, but significantly lacking in the rights sphere. That is, Camphill does a wonderful job of meeting students' and villagers' basic life needs, including their need for support, and it also allows them great freedom to express their creativity through artistic workshops and participation in cultural events. What is missing is simply the democratic participation that is the hallmark of the "middle sphere."

This is a complex challenge because intellectual disabilities, which often include communicative impairments, directly impact democratic participation in ways that vary widely from one person to another. Some people do not speak at all. 
Others communicate effectively, but experience severe anxiety when asked to make decisions that will impact others, or to grapple with such upsetting topics as sexual abuse. Still others may be adept at political participation, but may advocate for policies that are not well suited for the full range of persons with learning difficulties. All of these complexities could be used as an excuse, to argue that the slogan of "nothing about us without us" does not apply in cases of intellectual disability. A better response would be to recognize them as challenges to redoubled effort and commitment, and above all to a deeper dialogue with advocates from beyond Camphill.

That is in itself a challenge, because the self-advocacy movement itself is not yet fully inclusive of all persons with intellectual disabilities. It is wonderful when Camphillers with learning difficulties can join self-advocacy organizations in which they get to know other persons with similar disabilities who live in other, more "mainstream" settings. Such relationships can make it easier for the Camphillers to discern whether Camphill is indeed their preferred home, and to articulate ways to make it more suitable for them. But in fact many advocacy organizations are populated by persons who are quite different from those who live in Camphill. The principle of "nothing about us without us" was first articulated by activists with physical disabilities. One of the books introducing the slogan explicitly apologized for "the absence of people with mental and cognitive disabilities," despite the fact that they "combine to make up the largest disability 'category."' ${ }_{161}$ When persons with intellectual disabilities joined the conversation, people with autism who had strong written communication skills often were at the forefront.

The Autism Self-Advocacy Network, founded in 2006, is the advocacy organization with by far the greatest impact on current U.S. policy related to "care in the community" and other issues of social inclusion. Its website proudly displays the words "nothing about us without us"; it also reveals that at least five of the eight members of the organization's board of directors hold graduate degrees. ASAN has a strong commitment to cross-disability alliances and activism, and has articulated a pointed critique of the common distinction between "high" and "low" functioning individuals, since every person has a unique blend of functions they can perform easily and those with which they struggle. ${ }^{162}$ Nevertheless, its current structure reveals it is also on a journey toward full inclusion. There is no perfect group that Camphillers can simply join; rather, Camphillers should participate more fully in organizations like ASAN precisely in order to help them achieve their best aspirations.

Camphill's capacity to engage in that dialogue has been further limited by changes within Camphill that were themselves partly consequences of disability rights activism. As activists have urged that persons with learning difficulties be placed in the least restrictive setting possible, social care authorities have become much less willing to place persons with mild impairments at Camphill. Simply to survive, many Camphills have rebranded themselves (at least in their conversations 
with social care authorities) as specialized care facilities for profoundly disabled, usually nonverbal, individuals, or for people who have psychological, emotional, or behavioral challenges in addition to intellectual disabilities. Thus, the people who are most able to participate in the disability rights movement, as currently constructed, are unlikely to live at Camphill, while those who do live at Camphill would need a great deal of support merely to connect with the movement. All of this occurred at a time when many Camphill places were experiencing power struggles that diverted energies away from the practical empowerment of students and villagers.

The earliest reference to self-advocacy in Camphill's newsletter appears in a 2002 review of a book, Advocacy and Learning Disability, coedited by long-time Camphill ally and historian Robin Jackson. Neither the review nor the book is exclusively about self-advocacy, but give at least equal attention to "citizen advocacy," a concept first introduced by Wolf Wolfensberger. A citizen advocate, the review explains, is an unpaid and independent citizen who "creates a relationship with a person who is at risk of social exclusion and chooses one or several of many ways to understand, respond to, and represent that person's interests as if they were the advocate's own." The reviewer rightly notes that such practices are well established in Camphill, but gently prods the movement to embrace them even more fully. ${ }^{163}$ Implicitly, the review makes a point that is also borne out in the structures of many self-advocacy organizations for people with intellectual disabilities other than autism: for people with profound disabilities, self-advocacy often requires the partnership of strong citizen advocates. Most Down syndrome self-advocacy programs are not independent in the way ASAN is, but sponsored by umbrella organizations not exclusively directed by persons with disabilities. This has consistently been the style of self-advocacy in Camphill: it is initiated by coworkers or employees as a strategy for strengthening the rights sphere, rather than being created autonomously by persons with special needs themselves.

Camphill's hesitant embrace of self-advocacy often accompanied its effort to come to terms with legacies of sexual abuse. Like other organizations that work with vulnerable people, Camphill has never been entirely free of abuse. Sometimes this has been perpetrated by coworkers against individuals with special needs; sometimes it has been perpetrated by people with intellectual disabilities, either against other people with disabilities or against the children of coworkers. In some cases this occurred because people were not supported in finding healthy ways of expressing their sexual desires; in many cases it was exacerbated by Camphill traditions of placing unrelated adults and children in large family-style houses, and frequently moving them from house to house in ways that may have benefited some while compromising the freedom of others. Whether a coworker or a villager was the perpetrator, moreover, Camphill's practice of lifesharing made it difficult to protect others from harm without disrupting entire households, to say nothing of the lives of perpetrators who may themselves have needed care 
and support. In these cases, conversations about self-advocacy were confusingly tangled up with conversations about abuse, communal practices, and governance. That tangle might have been avoided had the movement proactively embraced practices of self-advocacy earlier.

Camphill Village Nottawasaga in Ontario was one place that enthusiastically embraced practices of self-advocacy in response to a painful episode of sexual abuse. In 2003 the Ontario government investigated multiple allegations of physical and sexual abuse perpetrated by coworkers, and ultimately mandated a restructuring of the board to exclude coworkers, the dismantling of the community's incomesharing structure, and the appointment of a nonresidential executive director. ${ }^{164}$ In the wake of these changes, coworker Chuck Kyd, then serving as president of the Camphill Association of North America, participated in the 2005 Camphill International Dialogue, where "self-advocacy" was identified as one of four program priorities within the "sphere of rights." 165 Soon thereafter the community hosted a conference where thirty-five visitors joined forty-five local residents to "explore the way self-advocacy is becoming manifest in our Camphill places." This was a time of deep learning from advocates beyond Camphill, as well as from the experiences of the participating communities. The conference began with a keynote by Judith Snow, a nationally prominent self-advocate from the community of people with physical disabilities. Another speaker, Judy Beeforth, addressed the theme of self-advocacy from the perspective of First Nations communities, and led the participants in creating a medicine wheel as a permanent part of the Nottawasaga property. After hearing from these outsiders, participants told their own communities' stories, often stressing collaboration with other organizations such as the "Speaking for Ourselves" group in Pennsylvania. They highlighted practices that allowed people with special needs to choose more individualized or independent living situations, or attain employment outside of Camphill. And they urged the movement to conduct similar events more frequently. ${ }^{166}$

Participants from both Camphill Nottawasaga and Camphill Soltane singled out Julia Wolfson as an inclusion consultant who helped them "bring about new attitudes and approaches to how we truly support our villagers and companions in a way that benefits all in our communities." ${ }^{167}$ Wolfson's influence in Camphill extends far beyond those two places. She has consulted widely with Camphill communities, especially in the wake of incidents of sexual abuse, and her work with Camphill communities in Norway, Botswana, and South Africa culminated in her 2013 dissertation, which explores "the role of inner empowerment in intentional personal and collective transformation in human service environments." ${ }^{168}$ Wolfson portrays Camphill places as idealistic communities that played an important role in the early empowerment of people with disabilities, but sometimes "slid into disjuncture" because of conflict, complacency, or a failure to engage sources of wisdom from beyond their walls. 
Wolfson's work draws on anthroposophical spiritual resources, placed in creative dialogue with insights from other spiritual and psychological traditions. On her website she lists Rudolf Steiner as one of four "wise teachers" who helped her "discover attitudes and ways of developing self and society as indivisible aspects of our evolving world." She credits Steiner in particular with setting "me on a lifelong adventure" by introducing her to practical initiatives like Camphill, and for insisting that an inner change of thinking is needed for outer social conditions to change. She quotes Steiner to this effect, as well as his claim that "spirit is never without matter, matter is never without spirit." 169 In her dissertation, she describes Steiner's position as "ethical individualism," suggesting that her understanding of inner empowerment flows directly from his ideals. ${ }^{170}$ She draws extensively on models of organizational transformation that are influenced by Steiner, such as the work of Otto Scharmer, and devotes an entire chapter to "Lessons from Physics" that uses the work of Arthur Zajonc, a physicist and a former general secretary of the Anthroposophical Society in America. She also cites the "process-oriented psychology" of Arnold Mindell, who blended elements of Jungian psychology and quantum physics in developing strategies for transformation.

Wolfson is controversial as well as influential among Camphillers. Supporters praise her for opening their eyes to the value of self-advocacy; while critics fault her for encouraging communities to abandon lifesharing and incomesharing, and to replace flat leadership structures with hierarchical ones. This raises an important question: are lifesharing and incomesharing at odds with the true empowerment of people with special needs? If so, this would be a powerful reason for Camphill to follow the path of "evolving beyond community", as a way of fully honoring its founding commitment to the human dignity of persons with special needs.

Wolfson does not make a categorical argument against the preservation of traditional Camphill practices. Instead, she highlights ways they can become dysfunctional. She notes, for example, that the revolving door of young coworkers, though it might seem to be enriching for all parties, can be "detrimental" to villagers who must deal with "relationships repeatedly being made and broken." She faults the unexamined assumption that unsalaried caregivers will be more "altruistic" than those who receive a salary, and notes that "in a shared economy it is more difficult for practitioners and leaders to leave when they want to, or to be asked to leave." She asserts that "traditional homes of up to 15 people or more are being replaced with smaller group homes and apartment-style living because fewer people-leaders, practitioners and people receiving services alike-want to live, eat, share bathrooms and their precious downtime with a big group of people they have not chosen to live with." ${ }^{171}$ All of these are fair points, but Wolfson could perhaps do more to help communities reconcile the demands of self-advocacy with the values inherent in traditional practices.

Traditional Camphillers who are committed to incomesharing and lifesharing might reasonably object that Wolfson is too attentive to the dangers inherent in 
those practices, and insufficiently alert to the pitfalls that accompany conventional nonprofit structures-especially since most Camphills that have abandoned the former have embraced the latter. Some might go further and suggest that the emphasis on individual choice and "rights" inherent both in her work and in the disability rights movement as a whole is one-sided. It seems reasonable to insist that people should not have to live with housemates they haven't chosen, but for many people the more important priority is not having to live alone. However much those Camphillers might object to the way Wolfson applies her principles, they must acknowledge that the principles themselves are faithful to Rudolf Steiner's vision, as articulated both in the "Sociological Law" and in the idea of the epoch of the consciousness soul. In the modern age, Steiner insisted, there is simply no way to bypass individual freedom, even in pursuit of a sense of community that transcends individualism. For this reason, both Wolfson and disability rights activists may be indispensable conversation partners if Camphill is to create a future that truly honors its past.

Disability rights activism underlies many of the changes in social care provision discussed in the previous section, above all the idea of "personalization" - that each person with a disability should be able to choose a unique package of support services to ensure their full inclusion in society as a whole. The question this raises for Camphill, and indeed for any intentional community that hopes to include all people regardless of ability, is this: is there an inherent tension between the ideal of community and the ideal of individual rights? Is community the antidote to a culture that makes a false god of individual rights, or is community actually a vehicle through which individual rights can be more fully realized? Given its roots in anthroposophy, Camphill ought to opt unequivocally for the latter answer. Yet this still leaves the complex task of applying that principle in particular cases.

One Botton coworker, Jonathan Reid, told a story that got at the dilemma. As his community was working to embrace the new culture of personalization, they brought in a consultant to do a workshop that included a "personalization exercise" designed for the villagers. Each person was supposed to fill out a diagram with concentric rings signifying "the relative importance of different people in their life." The first question posed to the villager was, who goes in the center? "And the learning-disabled person said, God. And the whole exercise went out the window, because they were supposed to say, Me. . . I see that gesture again and again and again, and it is a real inspiration for what a community needs to be." ${ }^{172}$ Jonathan's point was not to suggest that every community should have a theistic basis. It was, rather, that many people (and perhaps especially people with intellectual disabilities) do not experience themselves as the center of the world. That insight is wholly in keeping with the disability rights movement's insistence that people with disabilities should not be segregated into settings focused on their individual neediness, but should participate fully in the larger world. 
Camphill coworker Mischa Fekete insisted, should refuse the dichotomy of accepting or rejecting personalization as it is currently defined, and instead think deeply enough about it to arrive at its own unique evolutionary response. "Social research has shown," he explained, "that service provision where you have ... the workshop, the residential, the social, the health, everything wrapped together ... people with special needs are generally not supported or empowered as individuals to the same degree as in services where people get a little bit here, a little bit there, they access the services that they feel they need." Since Camphill "has always prided itself on [its] holistic way of service provision," this is a huge challenge. "Suddenly you have to find your own answer to that. ... We need to find our unique answers. ... Fifty years ago, Camphill was cutting edge. Now we are considered a dinosaur. ... It is challenging mostly because it challenges your value system." ${ }^{173}$

The pressures toward more individualized services for people with special needs run parallel to the desires of many coworkers to set the terms of their relationship with Camphill, and these in turn run parallel to trends in a wide range of intentional community movements, from kibbutzim to 1960s-era spiritual communities. Traditionalists may be right to worry that all of this spells the end of true community, especially if it means that each of Camphill's constituencies gets broken down into ever smaller subconstituencies: residential villagers versus sheltered workshop participants versus people with special needs who participate only in the cultural life; lifesharing coworkers versus lifesharing employees versus nonresidential employees versus members of the inner community who no longer live at Camphill. But perhaps all of this opens a door to a new sense of unity. What would it mean if Camphill were to abandon categories like "villager" and "coworker" and instead welcome new members as people, without regard to disability or desire for a residential placement? It might then ask each member, "What gifts do you have to offer our community? What support do you need? Do you want to live here full time? Do you want to manage your finances individually or as part of a group?" Is it possible for Camphill to honor each person's radical individuality, but still welcome them all in through the same doorway?

\section{CAMPHILL CRISES AND RENEWAL}

For much of the Camphill Movement, the twenty-first century has been a time of crisis. After sixty years of steady growth, dozens of Camphill places faced real threats to their survival. These crises gave new relevance to the apocryphal story that Karl König had predicted that Camphill would die out in the twentyfirst century. Very few Camphillers today take it for granted that their movement will still be thriving in fifty or a hundred years. Yet even in the face of crisis, few Camphill places have closed altogether. A few have left the Camphill Movement; 
several have transformed themselves in ways that have caused other Camphillers to question their authenticity; some have renewed their commitment to Camphill traditions; and still others are seeking radically new ways of being faithful to those traditions. In this concluding section, I will tell the story of three crises-one mostly resolved and two ongoing at the time of this writing (2020) - that may provide clues about Camphill's future.

These stories all unfolded against a background of movement-wide anxiety. By 2000 it was unremarkable for the Correspondence to publish articles implying that Camphill was dying. A typical piece claimed that long-term Camphillers had been "saying 'goodbye' to Camphill for the last decade," as the old movement gave way to an "Institutional Camphill" preoccupied with measurable outcomes and an "Institutional Community" composed of nostalgic memories. ${ }^{174}$ The back pages of the Correspondence also swelled, as more and more communities found they needed to advertise aggressively in order to fill vacant positions as teachers, workshop leaders, and house coordinators. Yet advertisements also showcased newly established communities, and predictions of disaster coexisted with optimistic reports about new strategies for fostering community and new dialogues within and beyond Camphill. The newsletter even included a hopeful message from someone who had experienced similar challenges in another communal context. A former brother in a Catholic religious order who had dissolved the connection between that order and its own disability services program affirmed that "Camphill still had the opportunity to hold together what he had broken apart: a life of vocation, of living together through Christian ideals, with a modern, innovative social service for people with special needs."175

The crisis for Camphill Vidaråsen came just before the millennium, and it had two parts. Beginning in 1996, former staff children began reporting incidents in which they had been sexually abused by individuals receiving care. Because the abuse had not been reported at the time it occurred, several of the perpetrators had moved from house to house or from one Camphill village to another, increasing the total number of victims. ${ }^{176}$ This revelation caused a great deal of "soul searching," recalled one person who lived at the village at the time. "What was it about the life here that made such things possible?" Was lifesharing "a completely naïve experiment" in which "the staff children had paid the price"? Around the same time, they also learned that one member of the community had misappropriated coworker funds, calling into question their "rather chaotic, flat organizational" structure in which many long-term coworkers served on a leadership team but no one had primary responsibility for management. The controversy coincided with a decline in applications from potential villagers. Many coworkers felt "knocked out" as they began implementing steps to help the persons who had been harmed and prevent future abuse. ${ }^{177}$ In 2005 the management team realized that they needed help, and over the next five years underwent a grueling transformation. They held forums for victims, issued apologies, created new policies, and worked 
with a series of consultants. The consultants prompted multiple short-lived reorganizations of leadership, with new leaders often struggling to overcome the anxieties and opposition of community members with divergent views of the situation. Among the consultants with whom they worked in these years was Julia Wolfson, who already had amassed significant experience helping Camphills adapt to the new culture of social care and disability rights. ${ }^{178}$

The village embraced many of the changes recommended by Wolfson. They created a more formal leadership structure, guaranteed all coworkers two days off each week (either Friday and Saturday or Sunday and Monday), created some residential separation between villagers and staff kids, and reduced the incomesharing aspects of their salary structure. Wolfson, one person recalled, advocated "a whole new methodology which would safeguard the villagers, safeguard the coworkers, safeguard the coworkers' children, and focus much more on developing the individual potential of the villagers first and foremost." But Wolfson and her allies took it for granted that this could be achieved most readily "if the integrated living structure would be disconnected and that coworkers would receive salaries and there would be more focus on professional training and competence and qualification for the coworkers." Some long-term coworkers felt disrespected by this: "They had given the best part of their lives on a voluntary basis, and now there was a focus on whether they were doing anything useful or not." But their response was fairly passive; they were still "shell-shocked" by the revelations of abuse. ${ }^{179}$

Another obstacle to the proposed reorganization of Vidaråsen was the other Norwegian Camphills, who had veto power over the proposal insofar as all of them were part of a single charity. They persuaded the board of the Camphill Village Trust to threaten Vidaråsen with exclusion if they followed through on the plan. Many parents of villagers also opposed the changes. They remembered that, when Norway shut down its social care institutions, Camphill had been allowed to survive because it "was recognized as being a kind of inside-out integration." From that perspective, putting "the total focus on the development of the villagers at the expense of everything else seemed to be a contradiction in terms." And so the parents insisted that lifesharing was necessary to ensure that their children would be treated not as "patients" but as "fellow citizens, as colleagues and friends."180

Tensions simmered until 2010, when Vidaråsen's coworkers rallied in opposition to a proposal to hire a single, employed manager "who would have the executive powers with regard to use of money, employment, all the things that had previously been in the hands of the carrying coworkers." ${ }^{181}$ At this point, the coworkers asked Will Browne, a long-standing coworker who was no longer living in the village, if he would be willing to take on a new leadership position. Will had been the one who had first disclosed the financial misconduct, as well as being involved in the response to the abuse. All this took a toll on his health. He had stepped away for most of the period when Wolfson was developing her report. This gave him the distance he needed to "get myself rejuvenated and ... excited about coming back 
and helping to pick up the pieces but also to learn from the mistakes we had made before and from the positive aspects of [Wolfson's] plan." He told the community that he was willing to come back as a leader only if he were elected to that role as part of a new leader group. Vidaråsen then empowered its village council, encompassing all long-term coworkers who chose to take part, to elect a leadership group of three members, with staggered terms of service. They also stipulated that members of the leadership group need not have any specifically managerial skills, such as the ability to construct a budget, understand legislation, or use a computer. Will insisted that employees be chosen to perform these tasks in a supporting capacity, so that "the only criterion" for holding decision-making power was "that one is seen to be carrying the values of the village." On these terms, he was elected to the leadership team three times, playing a curiously hybrid role as both an employee who performed many administrative tasks along with the other office employees and an elected community leader. The other two founding members of the leadership team were long term coworkers. At the time of this writing, Will was eagerly anticipating the end of his service on the leadership team and a fresh immersion in his old life as a coworker and architect. ${ }^{182}$

In the years after its leadership transition, Vidaråsen took multiple steps to rebuild the Camphill traditions of incomesharing and lifesharing in new ways. Despite external regulations that forced the community to pay differential salaries, the residential coworker group chose to pool their incomes and thus maintain a needs-based economy. They recruited a strong circle of millennial-generation coworkers, some of whom had grown up at Vidaråsen and most of whom were deeply committed to both incomesharing and lifesharing. The community has also attracted many younger villagers, giving them abundant opportunities to deepen the practices of self-advocacy that Wolfson had helped introduce. ${ }^{183}$

Vidaråsen's crisis experience demonstrates that it is possible for a Camphill community to preserve significant aspects of its communal heritage even in the wake of an abuse crisis and even when a thoughtful, well-constructed proposal for the abandonment of incomesharing and lifesharing is already on the table. It also shows that this is far from easy. Vidaråsen's coworkers alone could not have prevented more sweeping change. They had to rely on the support of a national network in which the other communities were all even more committed to Camphill traditions. Unlike Camphill places in the UK and Ireland, Vidaråsen did not experience any significant governmental pressure to change: Camphill is extraordinarily well-regarded in Norwegian society and has its own line item in the national budget. Compared to regulators in other countries, the Norwegian authorities have been very hands-off in their approach to Camphill, and on those occasions when they have been engaged they have generally allowed the Camphillers to set the criteria for their own regulation. The support of the parent community was also essential, and this support might not have been so unified if the victims of the reported abuse had been villagers rather than staff kids. 
Most other Camphills that have faced challenges similar to Vidaråsen's have responded differently. I got a vivid sense of this when I visited Botton Village in the summer of 2016, arriving with my family on the day of the Brexit vote. Botton, which is located in England's North Yorkshire Moors, holds a special place in the Camphill Movement. Until recently, it was the largest Camphill community in the world, with about three hundred residents-enough to merit its own post office, as well as a grocery store, church, Waldorf school, publishing house, four separate farms, training seminars for various anthroposophical practices, and a few successful businesses. It was the first Camphill place established as a village for adults rather than a school for children, and thus serves as the prototype for the adult villages that today constitute the majority of Camphill places worldwide. Botton's primary founder was Peter Roth, one of the original group of refugees who was known for his open-minded demeanor and mentorship of the baby boomers who came to Botton in the 1960 s and 1970s. The landscape of Great Britain is dotted with newer Camphill places that were founded by former Bottonites who were encouraged by Roth to take the Camphill vision to new places.

It is thus tragic but not especially surprising that Botton is the epicenter of the current struggle over the future of Camphill. For several years it was divided into hostile camps; after three years of mediation the two parties agreed to a legal settlement under which two autonomous communities would coexist on the Botton grounds. ${ }^{184}$ One party included the majority of long-term coworkers, who were committed to the traditional Camphill practices of lifesharing and work without salaries. The other side was led by managers hired by the overarching charity, the Camphill Village Trust, who believed that a more conventional employment structure was needed to preserve Camphill's access to state funding in a time of austerity. A few long-term coworkers took that side, believing that Camphill needed to evolve in order to survive. Villagers, short-term coworkers, and employees generally found themselves caught between the factions, with some villagers and their family members advocating publicly on behalf of preserving Camphill traditions.

It is not my intent to pass judgment on this conflict: I have not spent nearly enough time at Botton to do so in a responsible manner. Nor do I wish to draw an easy parallel between the conflict within Camphill and the conflict that was raging in British society at the time of my visit. In fact, a rare point of agreement between the two groups of Camphillers was that both were horrified by Brexit. Camphill is a cosmopolitan movement, with many long-term coworkers drawn from across the EU and beyond, while the managers hired by the Camphill Village Trust are the sort of educated professional inclined to sympathize with the EU and a globalizing vision. Yet Botton's neighbors in North Yorkshire voted in favor of Brexit by one of the highest margins in the UK.

And that was one underlying source of the problem. Botton, like so many intentional communities past and present, is a prosperous and cosmopolitan 
community of refugees tucked in an economically depressed rural area that has derived few benefits from globalization. The local authorities, including the authorities responsible for the care of persons with disabilities, are deeply distrustful of Camphill. Several years ago, the distrust became so intense that Camphill Village Trust imposed a moratorium on the placement of new villagers at Botton Village, causing it to lose its status as the largest Camphill in the world. All the controversial changes enacted by the Camphill Village Trust represent an attempt, thus far only partly successful, to regain the goodwill of the local authorities. And this is occurring in the context of the Conservative government's overall policy of budget austerity, which has generally been supported by Botton's North Yorkshire neighbors.

It is hard to blame the Camphill Village Trust for doing whatever it can to keep Botton afloat in a hostile environment-and it is also hard to blame Botton's neighbors for being at least somewhat suspicious of a community dominated by outsiders, many of them well educated with access to outside financial resources, on an estate that was given to them by the family of a prime minister!

The good news is that the crisis forced both sides to reach out to neighbors. As the community of long-term coworkers diminished, the Camphill Village Trust had to look locally for new employees, thus doing a tiny bit to reduce the chronic unemployment of the region. Some of the long-term coworkers who were forced out of Botton, meanwhile, moved only as far as the next town, where they now manage a health food store as the economic hub of their newly autonomous community within Botton. They forged activist alliances with neighbors who, with more access to the community than I have had, felt able to take sides in the conflict. These included the local Anglican priest and a local doctor who had first observed that Camphill villagers were much healthier than other persons with intellectual disabilities, and then that their health declined dramatically with the changes imposed by the Camphill Village Trust. It appeared to me that most of the neighbors who had actively taken sides took the side of the long-term coworkers, but this may have simply been because the long-term coworkers were the ones who mostly coordinated my visit. The neighbor-allies I met were from the professional class, and I have no reason to believe that their views were shared by the working class majority. The neighboring allies joined with the families of villagers to create Action for Botton, an activist organization that raised funds, media attention, and other resources on behalf of the long-time coworkers. ${ }^{185}$

The long-time coworkers' creative symbiosis with their neighbors has now flowered into the new Esk Valley Camphill Community. Esk Valley includes eighty people living in nineteen households within and beyond Botton Village. Some of them work in Botton workshops that are still managed by CVT. Others spend their days in offsite initiatives controlled by Esk Valley, among them the Health Food Shop in Danby and a garden provided by the Anglican parish. Esk Valley has also brought a new cohort of young coworkers to Botton, after many years in which the community experienced a steady pace of departures with almost no 
new arrivals. ${ }^{186}$ All of this depends on the general support of neighbors such as the shop's customers. It also requires an especially interesting partnership with Avalon Group, a local nonprofit that licenses most Esk Valley households under its "Shared Lives" framework. Shared Lives is a model of disability care that is usually applied to individual family households that care for one, two, or three persons with special needs. Like other "Shared Lives" organizations, Avalon Group is broadly committed to the ideal of "care in the community" and has no history of support for care based in intentional communities. It agreed to work with Esk Valley only after a protracted period of negotiation, and it does not feature its relationship with Esk Valley prominently on its website. ${ }^{187}$ Nevertheless, the fact that they've agreed to work with households that practice incomesharing and lifesharing means that they must now defend those practices to policymakers. It also means that the other households that they license may start to dialogue with and learn from the Camphill model.

The legal settlement in Botton has also resulted in a new model of relationship between the families of villagers and Camphill Village Trust. As part of the settlement, CVT agreed to extend membership in the charity to family members, "so that all CVT beneficiaries shall be entitled to have at least one relative/guardian/ family member as a CVT member. It also created a "Family Reference Group" on a trial basis at another of its village communities, Delrow. This "is not a decisionmaking body but does provide an avenue for 2-way information sharing between families and the charity." Once the trial is complete, similar bodies will be established at Botton and the Grange. CVT also agreed to bring one of the claimants onto its board immediately, and to allow another to fill the next vacancy designated for a family member. Though the consequences of these changes are uncertain, they have the potential to formalize the role of family members as an integral part of Camphill's social organism.

Perhaps the most exciting outcome of the Botton conflict is that the patterns of Camphill development-evolving beyond community and creative symbiosiswill now occur side by side. If the mutual animosity diminishes, each side will have abundant opportunities to learn from the other's experience; even if it remains, they will hardly be able to ignore one another's successes and failures. The results of their dialogue will doubtless reverberate through the rest of Camphill.

Another sort of dialogue is currently occurring among the Camphill communities in the United States. Though these communities have adopted widely variant approaches to incomesharing and lifesharing in the past decade, they have retained fairly open lines of conversation and connection through the Camphill Association of North America and the Camphill Foundation. Much of that dialogue today concerns the "Final Rule" for "Home and Community Based Services" that was issued by the Centers for Medicare and Medicaid Services in 2014. ${ }^{188}$ It defines what it means for services to be provided "in the community," as opposed to "in an institution," and thus to have automatic eligibility for Medicaid funding. 
It also contains provisions for waivers that would direct some funding to entities that do not fully comply with the rule.

The Final Rule, crafted in collaboration with the Autism Self-Advocacy Network and other disability rights organizations, requires any program receiving funds for services in the community to guarantee participants integration into the larger community, choice among a variety of settings, individual rights, and as much personal autonomy as possible. But it also contains a passage that describes what "in the community" is not, and this passage reads as if it were designed specifically to exclude programs like Camphill. "Farmsteads or disability-specific farm communities," "gated/secured community for people with disabilities," "residential schools," and "multiple settings co-located and operationally related," are all described as "typically having the effect of isolating people from the broader community," even if they are deliberately crafted to bring people with and without disabilities into community together. It appears that Camphill is not the primary intended target of this section: the crafters of the policy seem to have been reacting primarily to a trend among wealthy parents of persons with autism to create farms or communities intended to shelter their children from the stresses of mainstream society. But the effect is potentially devastating to Camphill, since even the practices that Camphill has been adopting in response to calls for mainstreaming, such as the creation of smaller communities in urban settings, still fall well outside the Final Rule's definition of "in the community." 189

The essential logic of the Final Rule is that an intentional community cannot be "in the community." This is why the Final Rule should be of interest to anyone who studies intentional communities, not just those interested in communities with a mission related to disability. The Final Rule might appear to be unique to Camphill's social care mission, not relevant for other sorts of intentional communities, but it echoes previous episodes in the history of communalism. Karl Marx's critique of "utopian socialism," for example, was in many ways a rejection of the refugee mentality found at Camphill: if some people are being treated unjustly by mainstream society, the proper response is to fight to change society, not to create places of shelter from it. In the 1840s, when Brook Farmers and other veterans of the Fourierist movement tried to take their communal ideals into the labor movement, they were sometimes received skeptically by working-class organizers who perceived them as bourgeois interlopers with lots of strange spiritual baggage. The hippie movement of the late 196os and 1970s was also characterized by tension with more political movements that insisted on direct confrontation with unjust social structures, rather than the creation of isolated communities. And there is the potential today for similar tensions between ecovillages and climate justice activists focused on direct confrontation with fossil fuel corporations, though for the most part this tension has not yet manifested.

Camphillers have responded to the Final Rule in diverse ways. Many Camphill places have reached out to other intentional communities affected by the Final Rule, forming coalitions such as Together for Choice and Coalition for Community 
Choice to advocate for the principle that all people with disabilities have a right "to live, work and thrive in a community or setting of their choice."190 (Because of lobbying efforts in the United States, it is possible that policy here will have changed significantly between the time of this book's writing and its publication.) It is hard to disagree with the principle of choice, yet implicit in it are significant challenges to Camphill. First is the challenge of discerning whether Camphill's residents with special needs have truly chosen to live there. Not all Camphillers use language to express their preferences. Among those who do use language, many have not experienced other residential options extensively enough to make an informed choice-just as people who live in urban group homes or private apartments may not have experienced Camphill-style community extensively enough to choose against it. Ordinarily, Camphill places require new residents to experience lengthy trial visits before making a final choice, and most have supported the departure of residents who discerned that they no longer wanted to live in Camphill. Yet one long-term Camphiller estimated that only five or six disabled residents of her community had made a truly free choice-adding that these people did much to sustain the cooperative spirit of the entire community. ${ }^{191}$

To the extent that Camphills support the choice making of their residents with disabilities, they may be challenged to make significant changes to their way of life. It could become clear that many villagers regard Camphill as a compromise that is valuable in some respects but far from ideal in others. Perhaps most residents of rural villages would rather live in town communities. It could become clear that Camphill is an appealing choice because of features that it does not share with "disability-specific" communities, such as the presence of large numbers of nondisabled persons who do not see themselves primarily as caregivers, but as farmers, artisans, or priests. Such a discovery would call into question the wisdom of aligning with the other communities in the policy arena. Conversely, it may be the case that many Camphillers with disabilities would prefer life in a disabilityspecific rather than lifesharing community.

The use of "choice" as a rallying cry for advocacy raises the question of how choice should be balanced with other values. Many disability rights advocates would argue that no one should be offered the "choice" to live in institutions with a track record of undermining human dignity, since such a choice is by definition not an informed choice. Camphillers would surely agree with respect to some institutional settings, however much they might object to applying the same argument to intentional communities in general. Camphillers also frequently appeal to the superior health outcomes experienced by people living in Camphill, even though it seems likely that these derive in part from community practices-healthy diets, active lifestyles, limited television-that are imposed uniformly on all residents rather than freely chosen by individuals.

Almost all Camphillers object to the Final Rule's underlying assumption that the only way to be "in community" is to be fully immersed in the residential and economic structures of the larger society, however inimical these may be 
to human thriving. To some, the Final Rule embodies the "there is no alternative" logic of neoliberal capitalism since the end of the Cold War. Others, more directly influenced by Rudolf Steiner, regard the checkbox criteria for discerning whether a particular program is or is not "in the community" as a classic example of "Ahrimanic" or excessively materialistic thinking. Steiner predicted that materialistic thinking would become ever more widespread with the approach of the incarnation of the demon Ahriman. Privately, some Camphillers use the word "Ahrimanic" to describe the logic of the Final Rule; publicly, they are more likely to couch their opposition in terms of the dangers of "bureaucracy."

Yet Camphillers also discern in the Final Rule a gesture of welcome from the larger society. At the heart of the Final Rule is the principle that persons with developmental disabilities should be able to live anywhere, work anywhere, and access any social resource that is available to persons without a disability. No Camphiller would reject this principle, yet in opposing the Final Rule they run the risk of being perceived as opposing it. A better strategy would be to embrace an open dialogue, seeking both to publicize the ways in which Camphill already embodies the ideals of the Final Rule and to change the aspects of its practice that run counter to those ideals. From an anthroposophical perspective, such a dialogue would help Camphill fulfill one of the central spiritual tasks of the present age, which is to engage creatively with the evolutionary trend toward greater materialism and individualism.

What makes this moment in Camphill history especially challenging is that both interpretations of the Final Rule may well be correct: it may embody a materialistic worldview that is inimical to genuine community and be a sign that the larger society is now ready to embrace both persons with special needs and the communal ideals of Camphill. That both/and interpretation is usually the dominant approach when Camphillers gather as a group to discuss the Final Rule. They are genuinely alarmed about the Final Rule, and eager to work creatively with the Rule and, especially, with the disability self-advocacy groups that had helped craft it. Similarly, they are eager to foster new partnerships with other intentional communities engaged in social care, but also aware that some of those communities may embody patterns of paternalism or institutionalization that should not be defended. What's more, Camphillers are willing and able to think about the Final Rule both in publicly accessible terms and in relation to the anthroposophical spirituality that has accompanied Camphill throughout its history. For me, that is perhaps the most hopeful sign about Camphill's future. 


\section{Conclusion}

The future of Camphill is uncertain. The movement has grown and thrived for eighty years, but it is at least remotely possible that it will not reach its hundredth anniversary. More plausibly, by the time it celebrates that anniversary in 2039, Camphill may have evolved decisively beyond its communal stage, becoming a network of educational and care facilities for persons with disabilities. Or it may have ceased to be a network of lifesharing communities, in which persons with and without disabilities create community together, and become a network of disability-specific intentional communities populated entirely by persons with intellectual disabilities. On the other hand, it is possible that by 2039 Camphill will have decisively reaffirmed its communal identity by creating new organizational structures that empower people of all abilities to choose cooperation over selfsufficiency, sharing over private wealth, and spirituality over bureaucracy. And it is possible, even likely, that in 2039 it will be possible to tell both hopeful and despairing stories about Camphill's future, just as is the case today.

From my own perspective, the key to a hopeful future may be the movement's willingness to expand its decision-making structures to include all the people who have contributed to the growth of the movement thus far: students, villagers, coworkers, young coworkers, employees, parents, board members, and many more. Initially, some of these constituencies were invited into Camphill on an instrumental basis, with the expectation that they would make a limited contribution without directly shaping Camphill's culture. But if-as anthroposophy teaches-everything is interconnected, then it is not only unethical to instrumentalize another person, it is also metaphysically incorrect. Whenever I enter into relationship with another person-or animal, plant, or even mineral-I invite that being to participate in my own evolutionary development. Camphill's challenge is to make that mutual participation fully conscious.

Camphill's future also depends on the capacity of people who cherish Camphill's traditions to recognize that ongoing change is itself a Camphill tradition. The 
founders of Camphill ensured the success of its first generational transition by opening their "inner community" to people who did not share their experience of exile, and by allowing decision-making power to pass out of the inner community and to even more inclusive bodies. A similar transition is needed today, both with regard to the structures that carry legal responsibilities for the governance of Camphill and the groups of people who carry responsibility for its spiritual essence.

Whatever the future may hold, Camphill has already demonstrated an important truth about intentional community: it is possible to create a cooperative alternative to mainstream society without cutting one's community off from the developmental processes active in the larger society. All of the utopian attempts to replace mainstream society with a fixed alternative blueprint have failed, because it is simply not possible to shelter any community from the larger ecology of society for more than a generation. Yet a community that takes responsibility for its own ongoing transformation may pose just as radical an alternative in its fifth generation as in its first. This is evident today not only at Camphill, but in a host of places that are continuing to evolve after one, three, or (in the case of monastic communities) dozens of generations.

Camphill's openness to ongoing transformation is the most important fruit of its rootedness in anthroposophy. Though anthroposophy is often perceived as a "conservative" force within Camphill, and though that perception sometimes accurately describes the behavior of individuals with a strong commitment to anthroposophy, the true spirit of anthroposophy is not conservative but evolutionary. Whenever Camphillers choose not to cling to particular social forms, but to attend creatively to change and evolution, they are reconnecting to anthroposophy.

Rudolf Steiner made this point when he proposed social threefolding as an alternative to both capitalism and socialism. Though he shared the socialists' conviction that in the twentieth century the private ownership of capital had become the source of much oppression, he refused to believe that the problem could have a once-for-all solution. "It is not possible," he insisted, "to ask how something that grows should be organized in order that this organization, which is thought to be correct, be preserved into the future. One can think in this way about something which remains unchanged from its beginnings. But it is not valid for the social organism. As a living entity it is constantly changing whatever arises within it. To attempt to give it a supposedly best form, in which it is expected to remain, is to undermine its vitality."

I heard a strong echo of Steiner's words in Veronika van Duin's account of Camphill's "central task." As the daughter of cofounder Barbara Lipsker, Veronika has lived through almost all of Camphill's history, and she blends the critical perspective of the staff kid with the commitment of the lifelong coworker. Anthroposophy, she reminded me, is both a "modern path of transformation" and a continuation of the work of the Rosicrucians, who served humanity without being noticed. In keeping with that tradition, Camphill's work is not about "bricks 
and mortar" or about being recognized. Rather, "the central task of Camphill is to continue to exist as a striving, messy, doesn't-quite-manage, anthroposophical attempt at community in which we always accept anybody who comes into our doors and try to show them that there are other ways to do things, there are other ways to think. To open minds, and then leave those people to live their lives as they choose, taking with them perhaps a little seed of that."

This is both a modest task and an audacious one. Unlike the utopias of the nineteenth century, Camphill has never sought to replace the larger society, only to renew it. It has never been a shining city on the hill, calling all the world's attention to itself. At times, it has been a "bubble," an "island," a self-enclosed society hidden in a valley, but in its fourth generation it can no longer be any of those things. It is, rather, a messy mix, planted deep in its many contexts, always growing-and in its continued growth, still inspiring and transforming those of us whose lives have been touched by it. 

NOTES

Each person I interviewed was given the opportunity to review a transcript of our interview and to comment on the passages I chose to include in the book. I also allowed them to determine whether they would be identified by name or kept anonymous. To ensure anonymity, I have provided only general information about places and dates for all of my interviews.

\section{INTRODUCTION}

1. There is no perfect terminology for identifying persons who experience some degree of cognitive impairment and whose self-realization has been limited by societal barriers and prejudices. In this book I will use the terms persons with intellectual disabilities, persons with learning difficulties, and persons with special support needs interchangeably, recognizing that each phrase is favored in certain contexts and that each phrase has both helpful and unhelpful qualities.

2. Angelika Monteux and Nick Blitz, "India Revisited," Camphill Correspondence, September-October 2000, 6-7; "News from Sadhana Village," Camphill Correspondence, March-April 2001, 18; "Sadhana Village," http://sadhana-village.org, accessed June 13, 2018; "Sadhana Village Introduction," www.youtube.com/embed/J5JAq2761ZQ, accessed June 13, 2018.

3. Sumesh Wadhera, "My Parents' Prayer Has Been Answered," Camphill Correspondence, July-August 2001, 10-11; "About Us," https://friendsofcamphillindia.in/about-us .html, and "Celebrations," https://friendsofcamphillindia.in/celebrations.html, accessed June 13, 2018; Monteux and Blitz, "India Revisited," 6-7.

4. It is hard to know exactly how many people are affiliated with Camphill, or even to know exactly which sorts of people should be counted in an attempted census. In 2016 I estimated conservatively that at least 5,250 persons currently reside at Camphill communities, including persons with disabilities, coworkers who share life with them, and the 
children of the coworkers, and I still stand by that as a rough estimate. One might also wish to count day students, adults who participate in day programs, and employees of Camphill, thus including everyone who is present at Camphill on a typical weekday. This was the approach taken in a 1976 movement-wide census that counted 4,262 persons, and in censuses conducted by the Scottish and North American regions in recent years. The Scottish census counted 1,436 persons and the North American census counted 1,716 persons. Since those regions accounted for 665 and 422 persons, respectively, in the 1976 census, one might infer that the movement is now between two and four times its size in 1976, with between 8,000 and 17,00o persons involved, not counting family members of residents, board members, or neighbors. See Alix Roth, "Camphill Census: Summer 1976," Camphill Correspondence, December 1976, 4-5; Dan McKanan, "Camphill at Seventy-Five: Developmental Communalism in Process," Communal Societies 36 (2016): 25-49; census produced by the Camphill Association of North America and provided privately to the author; "Camphill Scotland Return Statistics," document provided to the author by Kirsten Hogg, August 17, 2015.

5. Rudolf Steiner, Anthroposophical Leading Thoughts, trans. George and Mary Adams (London: Rudolf Steiner Press, 1973), GA 26. Most of Steiner's writings and lectures have been assigned a bibliographical number, prefaced by the initials GA for Gesamtausgabe, or "complete edition." These numbers making it easier for readers in English to identify texts that have been given different titles in different translations. English translations are available in searchable but unpaginated format at the Rudolf Steiner Archive, www.rsarchive .org. German texts can be found at the Freie Verwaltung des Nachlasses von Rudolf Seiner, http://fvn-rs.net. In quoting translations available at Rudolf Steiner Archive, I will generally cite the title, translator, GA number, and chapter or lecture number.

6. Dan McKanan, Eco-Alchemy: Anthroposophy and the History and Future of Environmentalism (Berkeley: University of California Press, 2017), xiii-xv, 2-7.

7. Rudolf Steiner, Theosophy: An Introduction to the Spiritual Processes in Human Life and in the Cosmos, trans. Catherine E. Creeger, GA 9 (Great Barrington, MA: Steiner Books, 1994); An Outline of Esoteric Science, trans. Catherine E. Creeger, GA 13 (Great Barrington, MA: Steiner Books, 1997); How to Know Higher Worlds: A Modern Path of Initiation, trans. Christopher Bamford, GA 10 (Great Barrington, MA: Steiner Books, 1994); and Christianity as Mystical Fact, trans. Andrew Welburn, GA 8 (Great Barrington, MA: Steiner Books, 1997). Those who wish to read Steiner's most influential writings in a single volume should obtain Robert McDermott, ed., The New Essential Steiner (Great Barrington, MA: Lindisfarne, 2009).

8. Helmut Zander, Anthroposophie in Deutschland (Göttingen: Vandenhoek and Ruprecht, 2007, 2008).

9. Rahel Uhlenhoff, ed., Anthroposophie in Geschichte und Gegenwart (Berlin: Berliner Wissenschafts-Verlag, 2011); Steiner, 1925 preface to Outline of Esoteric Science, 6-7.

10. Francis Edmunds, An Introduction to Steiner Education: The Waldorf School (Forest Row, East Sussex: Rudolf Steiner Press, 2004); McKanan, Eco-Alchemy, 13-22.

11. Richard Steel, a staffperson at the Karl König Archive, has unearthed the source of this misleading claim. In a letter written in 1953, König suggested that the Camphill inner community — not the movement as a whole! — would go through a series of developmental stages. Then, at a meeting of inner community members in 1965, he assigned dates to the stages, suggesting that a third stage would begin in 1953 and last for forty years, after which 
a new stage would begin. Notetaker Erika Schonlau paraphrased this chronology as "to the end of the century." The practice of seeking rhythmic patterns in history is quite common in anthroposophy: at the turn of the millennium, for example, Steel himself suggested that Camphill was entering a new stage, having completed two thirty-three-year cycles since its founders had first met. In such times, he acknowledged, "we may have the feeling today that the impulse of Camphill is finished with the year 1999"-but then went on to suggest the path to community renewal. Richard Steel, email correspondence with the author, June 12, 2018; Richard Steel, "The Inner Legacy of Anthroposophy at the Turning Point of the Millennium," Camphill Correspondence, September-October 2000, 3.

12. Interview with Jonny Mallam-Clarke at Camphill School Aberdeen, Scotland, July 2013.

13. Karl König, "The Three Essentials of Camphill," in A Portrait of Camphill: From Founding Seed to Worldwide Movement, ed Jan Martin Bang (Edinburgh: Floris, 2010), 28-36.

14. Karl König, "The Three Great Errors: A Chapter in Community Living," Cresset 3/1 (Michaelmas 1956): 6-16.

15. Michael Oliver, Understanding Disability: From Theory to Practice, 2d ed. (Houndsmill, Basingstoke: Palgrave Macmillan, 2009), 93.

16. Dan Goodley, Disability Studies: An Interdisciplinary Introduction (London: Sage Publications, 2011), 7.

17. Jana M. Bennett and Medi Ann Volpe, "Models of Disability from Religious Tradition: Introductory Editorial," Journal of Disability and Religion 22/2 (2018): 121-29; Sarah Imhoff, "Why Disability Studies Needs to Take Religion Seriously," Religions 8/9: 186.

18. John Swinton, ed., Critical Reflections on Stanley Hauerwas' Theology of Disability: Disabling Society, Enabling Theology (Binghamton, NY: Haworth Pastoral Press, 2004); Thomas E. Reynolds, Vulnerable Communion: A Theology of Disability and Hospitality (Grand Rapids, MI: Brazos Press, 2008); and Amos Yong, The Bible, Disability, and the Church: A New Vision of the People of God (Grand Rapids, MI: Eerdmans, 2011).

19. Donald E. Pitzer, "Developmental Communalism: An Alternative Approach to Communal Studies," in Utopian Thought and Communal Experience, ed. Dennis Hardy and Lorna Davidson, Geography and Planning Paper 24 (Enfield: Middlesex Polytechnic, 1989), 68-76. For application of developmental communalism to a wide range of intentional community movements in the United States, see Pitzer, ed., America's Communal Utopias (Chapel Hill: University of North Carolina Press, 1997).

20. Donald E. Janzen, "The Intentional Community-National Community Interface: An Approach to the Study of Communal Societies," Communal Societies 1 (Autumn 1981): 37-42.

21. Interview with Tom Marx at Camphill Tigh a'Chomainn, Scotland, July 2013.

22. I am grateful to Andrew Plant for calling my attention to the role of crises in communal evolution; email correspondence, August 6, 2018.

23. Oliver, Understanding Disability, 87-105; Sharon V. Betcher, Spirit and the Politics of Disablement (Minneapolis: Fortress, 2007).

24. Autism Self Advocacy Network, "Keeping the Promise: Self-Advocates Defining the Meaning of Community Living," 2012, at https://autisticadvocacy.org/policy/briefs /keeping-the-promise-self-advocates-defining-the-meaning-of-community-living, accessed April 13, 2019. 
25. Stanley Hauerwas and Jean Vanier, Living Gently in a Violent World: The Prophetic Witness of Weakness (Westmont, IL: IVP, 2008).

26. Ralph Waldo Emerson, "Fourerism and the Socialists," The Dial 3 (July 1842): 88.

\section{CAMPHILL GENERATIONS}

1. John Baum, "The Youth Group in Vienna," in The Builders of Camphill: Lives and Destinies of the Founders, ed. Friedwart Bock (Edinburgh: Floris, 2004), 11-38.

2. Rüdiger Grimm, "Highlights in the Development of Curative Education and Social Therapy," in Waldorf Education Worldwide, trans. Johanna Collis and Martyn Ransom (Berlin: Friends of Waldorf Education, 2001), 36-41; Volker Frielingsdorf, Rüdiger Grimm, and Brigitte Kaldenberg, Die Geschichte der anthroposophischen Heilpädagogik und Sozialtherapie (Dornach, Switzerland, Verlag am Goetheanum, 2012).

3. Rudolf Steiner, Curative Education: Twelve Lectures for Doctors and Curative Teachers, trans. Mary Adams (London: Rudolf Steiner Press, 1972), lecture 2, GA 317.

4. Ibid., lecture 9.

5. Ibid., lecture 10.

6. H.H. Koepf, "Significant Progress in Bio-Dynamics in the Scandinavian Countries," Bio-Dynamics 84 (Fall 1967): 1-8.

7. Sólheimar Ecovillage, "History of Sólheimar," www.solheimar.is/en/solheimar/history -of-solheimar, accessed July 17, 2018.

8. Ruskin Mill Sunfield, "History of Sunfield," www.sunfield.org.uk/about-sunfield /history-sunfield, accessed July 17, 2018; Volker Frielingsdorf, Rüdiger Grimm, and Brigitte Kaldenberg, Geschichte der anthroposophischen Heilpädagogik un Sozialtherapie (Dornach, Switzerland: Verlag am Goetheanum, 2013), 145-52.

9. Karl König, "Autobiographical Fragment," in My Task: Autobiography and Biographies, ed. Peter Selg (Edinburgh: Floris, 2008), 19-28.

10. Margarete von Freeden, “Tilla König," in Builders of Camphill, ed. Bock, 54-55.

11. "Hartmut von Jeetze," in Erika Nauck, We Came ... Biographic Sketches of the TwentyFive Participants of the First Camphill Seminar in Curative Education 1949-1951 (Aberdeen: Private Publication, 2009), 50; Robin Jackson, "The Camphill Movement: The Moravian Dimension," Journal of Moravian History 5 (Fall 2008): 88-100; Karl K. König, "The Three Stars of the Camphill Movement," in The Spirit of Camphill: Birth of a Movement, ed. Richard Steel (Edinburgh: Floris, 2018), 90-107.

12. Karl König, "Meditations on the Camphill Movement I," Cresset 6/2 (Christmas 1959): 10.

13. Ibid.

14. T.H. Meyer, The Development of Anthroposophy since Rudolf Steiner's Death (Great Barrington, MA: Steiner Books); Karl König, "Autobiographical Fragment," 20; Peter Selg, "A Biographical Sketch," in König, My Task, 56.

15. "The Executive Board's Letter to Adolf Hitler," in Meyer, Development, 228-31; McKanan, Eco-Alchemy, 31-35.

16. Cited in Hans Müller-Wiedemann, Karl König: A Central European Biography of the Twentieth Century (Botton Village: Camphill Books, 1996), 196.

17. The Haughtons also provided indirect links to other phases of communal history. As a boy, Theodore had attended the influential Rugby School, which inspired a nineteenthcentury community in Tennessee. One of his artist friends was the father of Thomas Merton, 
perhaps the most influential figure in the renewal of Catholic monasticism in the twentieth century. Robin Jackson, “The Origins of Camphill: The Haughtons of Williamston Part I: Theodore Haughton," Camphill Correspondence, November-December 2005, 10-13.

18. Karl König, address given May 28, 1939, cited in Müller-Wiedemann, Karl König, 449.

19. Anke Weihs, "Fragments from the Story of Camphill," part 1, Camphill Correspondence, May 1975, 2-4.

20. Weihs, "Fragments," part 3, Camphill Correspondence, July 1975, 3-4.

21. Weihs, "Fragments," part 5, Camphill Correspondence, September 1975, 3-4.

22. Michael Luxford, "The English and Welsh Region," in A Candle on the Hill: Images of Camphill Life, ed. Cornelius Pietzner (Edinburgh: Floris, 1990), 109-110; Sue Smith, "Sheiling School Pioneers," Camphill Correspondence, November/December 2001, 8-9.

23. Anke Weihs, "Fragments," part 5, 3-4; Karl König, The History of the Bible-Evening, lecture given August 30, 1953 (Aberdeen: Aberdeen University Press), 4-5.

24. Hans Schauder, Vienna-My Home, collected and recorded by Horst Werner Franke (Edinburgh: privately published, 2002), 123-24.

25. It is noteworthy that the defectors had been members of the earlier youth group in Vienna, rather than the one founded directly by König, and also noteworthy that they retained a practice similar to the Bible Evening at Garvald.

26. Karl König, "The First Memorandum," Michaelmas 1945, cited in Richard Steel, introduction to König, Spirit of Camphill, 18-19.

27. König, History of the Bible-Evening, 7.

28. König, "The Third Memorandum," in König, History of the Bible-Evening, 9; email correspondence with Richard Steel, August 2, 2018.

29. Email correspondence with David Adams, September 15, 2018.

30. Luxford, "English and Welsh Region," 112-13.

31. Karl König, "Masks of Humanity and Leading Images," in Seeds for Social Renewal: The Camphill Village Conferences, ed. Wanda Root and Michael Schmundt (Edinburgh: Floris, 1986), 50.

32. Andrew Hoy, "From Curative Education to Social Therapy," Camphill Correspondence, May-June 2001, 1.

33. König, "Three Great Errors," 6-16.

34. Ibid.

35. Ibid.

36. Editorial, Cresset 3/1 (Michaelmas 1956): 3-5.

37. Interview with a longtime Camphiller in North America, April 2014.

38. Jonathan Stedall, Where on Earth Is Heaven? (Stroud, Gloucestershire: Hawthorn Press, 2009), 91.

39. Munda Dudok van der Heel and Eileen Haywood, "Funeral Address for Susan Calvert, 1939-1999," Camphill Correspondence, January-February 200o, 16.

40. Interview with a longtime Camphiller in Norway, July 2016.

41. Interview with a long-time Camphiller in North America, April 2014.

42. Interview with a longtime Camphiller in Norway, July 2016.

43. Ibid.

44. Ibid.

45. Interview with a longtime Camphiller in Scotland, July 2013.

46. Interview with a longtime Camphiller in Norway, July 2016.

47. Email correspondence with Penelope Baring, October 4, 2018. 
48. Interview with a longtime Camphiller in Scotland, July 2013.

49. Interview with a longtime Camphiller in Norway, July 2016.

50. Richard Poole, editorial in Camphill Correspondence, January 1975, 1.

51. Alix Roth, "Camphill Census: Summer 1976," Camphill Correspondence, December $1976,4-5$.

52. Mark Gartner, "A Camphill Urban Community, the Wider 'Community' and Legislation," Camphill Correspondence, April 1985, 3-6.

53. John Baker, “The Croft-Malton," Camphill Correspondence, September 1975, 11.

54. Ibid.

55. John Baker, “The Croft-Old Malton-Yorkshire," Camphill Correspondence, July 1976,8 .

56. Interview with Veronika van Duin at Camphil Holywood, Ireland, July 2013.

57. Interview with Mischa Fekete at the Bridge Camphill Community, Ireland, August 2013.

58. Trude Amann, et al., "Letter from Scotland 2," Camphill Correspondence, November 1975, 2-3.

59. Angelika Monteux, "Cairnlee House: A Place of Youth Guidance," Camphill Correspondence, January-February 2000, 21.

6o. Camphill Soltane, www.camphillsoltane.org, accessed August 1, 2018.

61. Interview with a Camphill coworker in Ireland, August 2013.

62. Interview with Sherry Wildfeuer at Camphill Village Kimberton Hills, North America, April 2014.

63. Interview with a Camphill coworker in Norway, July 2016.

64. Interview with a Camphill coworker in Ireland, August 2013.

65. Interview with a Camphill coworker in England, August 2013.

66. Interview with Sherry Wildfeuer at Camphill Village Kimberton Hills, North America, April 2014.

67. Interview with Russ Pooler at Newton Dee Village, Scotland, July 2013.

68. Interview with Patricia Smith at the Cascadia Society, North America, July 2015.

69. Gwen Gardner, "Training to Become an Instrument for Peace," Camphill Correspondence, January 1976, 5 .

70. Interview with Jonathan Reid at Botton Village, England, June 2016.

71. Christof Andreas Lindenberg, "Early Glencraig Memories," part 3, Camphill Correspondence, December 1975, 3.

72. International Voluntary Service, "Our History", https://ivsgb.org/history/, accessed March 8, 2018.

73. Interview with a Camphill coworker in North America, April 2014.

74. Ibid.

75. Interview with Michael Babitch at Camphill Village Kimberton Hills, North America, April 2014.

76. Interview with a Campill coworker in Ireland, August 2013.

77. Charles Bamford and Rita Kort, "Camphill Eurythmy School: A New Beginning," Camphill Correspondence, May-June 2000, 9.

78. Interview with one of the founders of Camphill Devon, July 2013.

79. Interview with Ruth Tschannen at the Cascadia Society, North America, July 2015. 
8o. Richard Poole, editorial in Camphill Correspondence, June 1975, 2.

81. Interview with Stephen Sands at Cherry Orchards Camphill Community, England, August 2013.

82. Interview with Steve Lyons at Camphill Scotland, July 2013.

83. Interview with Sherry Wildfeuer at Camphill Village Kimberton Hills, North America, April 2014.

84. Interview with a Camphill coworker in England, August 2013.

85. Interview with Jonathan Reid at Botton Village, England, June 2016.

86. Interview with a longtime Camphiller in Norway, July 2016.

87. Interview with Russ Pooler at Newton Dee Village, Scotland, July 2013.

88. Interview with a Camphill coworker in Ireland, August 2013.

89. Interview with a Camphill coworker in North America, April 2014. The First Class is devoted to esoteric spiritual exercises and includes many longterm, devoted members of the Anthroposophical Society.

90. Email correspondence with Penelope Baring, October 4, 2019.

91. Interview with a Camphill coworker in England, August 2013.

92. Interview with a Camphill coworker in North America, April 2014.

93. Email correspondence with Penelope Baring, October 4, 2019.

94. Interview with Christoph Hanni at Camphill School Aberdeen, Scotland, July 2013.

95. Email correspondence with Penelope Baring, October 4, 2019.

96. Douglas Urton and Coleman Lyles, "Christmas Conference-U.S.A.," Camphill Correspondence, February 1975, 11.

97. Interview with Michael Babitch at Camphill Village Kimberton Hills, North America, April 2014.

98. Poole, editorial in Camphill Correspondence, January 1975, 2.

99. Interview with Jonathan Reid at Botton Village, England, June 2016.

100. Interview with a Camphill coworker in Norway, July 2016.

101. Interview with Simon Beckett at Newton Dee Village, Scotland, July 2013.

102. Interview with a baby boomer who has experienced Camphill life in many locations, September 2013.

103. Interview with a Camphill coworker in Scotland, July 2013.

104. Interview with a Camphill coworker in Scotland, July 2013.

105. Interview with a Camphill coworker in Scotland, July 2013.

106. Interview with a Camphill coworker in England, August 2013.

107. Interview with Russ Pooler at Newton Dee Village, Scotland, July 2013.

108. Interview with a Camphill coworker in Ireland, July 2013.

109. Interview with Russ Pooler at Newton Dee Village, Scotland, July 2013.

110. Interview with a Camphill coworker in Ireland, July 2013.

111. Interview with a Camphill coworker in North America, July 2015.

112. Interview with Steve Lyons at Camphill Scotland, July 2013.

113. Interview with a Camphill coworker in England, August 2013.

114. Interview with Simon Beckett at Newton Dee Village, Scotland, July 2013.

115. Interview with Jonas Hellbrandt at Newton Dee Village, Scotland, July 2016.

116. Interview with Neil Henery at Camphill Scotland, July 2013.

117. Interview with a Camphill coworker at Newton Dee Village, Scotland, July 2013. 
118. Interview with a Camphill coworker at Newton Dee Village, Scotland, June 2016.

119. Interview with Tobias Pedersen at Camphill Grangebeg, Ireland, August 2013.

120. Interview with a Camphill coworker in Ireland, August 2013.

121. Interview with a Camphill coworker in North America, April 2014.

122. Informal conversation with a Freunde der Erziehungskunst staffperson, May 2018.

123. Interview with a Camphill coworker in Scotland, July 2013.

124. Interview with a Camphill coworker in Ireland, July 2013.

125. Interview with Marjan Sikkel at Newton Dee Village, Scotland, July 2013; email correspondence with Marjan Sikkel, March 20, 2018.

126. Interview with a Camphill coworker in North America, April 2014.

127. Interview with a Camphill coworker in Scotland, July 2013.

128. Interview with Tom Marx at Camphill Tigh a'Chomainn, Scotland, July 2013.

129. Interview with a Camphill coworker in Scotland, July 2013.

130. Interview with Guy Alma at Camphill Special School, North America, April 2014.

131. Interview with Ruairidh von Stein at Botton Village, England, June 2016.

132. Hans Heinrich Engel, "A Letter from Hans Heinrich," Camphill Correspondence, February 1976, 2-3.

133. Interview with a Camphill coworker in Scotland, July 2013.

134. Interview with a Camphill coworker in England, August 2013.

135. Interview with a Camphill coworker in Scotland, July 2013.

136. Nora and Friedwart Bock, "A New Community in Latvia," Camphill Correspondence, November-December 2001, 6.

137. Vilnis Neimanis, "Rozkalni, Camphill Village, Latvia," Camphill Correspondence, May-June 2002, 14.

138. Richard Swann, "České Kopisty: A New Camphill Initiative in the Czech Republic," Camphill Correspondence, March-April 2002, 14.

139. Johannes Surkamp, "Work in Romania," Camphill Correspondence, SeptemberOctober 2000, 8.

140. Ha Vinh Tho, "A Camphill Inspired Initiative in Vietnam," in Portrait of Camphill, ed. Bang, 225-26; "Peaceful Bamboo Family-TTG," https://eurasia-foundation.org /projects/tinh-truc-gia, accessed May 8, 2020; “Tinh Truc Gia=The Peaceful Bamboo Family 10 Years!” www.eurasia.org.vn/bamboofamily.html, accessed May 8, 2020.

141. Interview with a Camphill coworker in Norway, July 2016.

142. Interview with a Camphill coworker in North America, July 2015.

143. Interview with a Camphill coworker in Norway, July 2016.

144. Interview with Russ Pooler at Newton Dee Village, Scotland, July 2013.

145. Interview with a Camphill coworker in Norway, July 2016.

146. Interview with a Camphill coworker in Norway, July 2016.

147. Interview with a Camphill seminar participant in Ireland, July 2013.

148. Interview with Martin Sturm at Camphill Clanabogan, Ireland, August 2013.

149. Interview with Jens-Peter Linde at Camphill Scotland, July 2013.

150. Interview with Jake Vollrath at Newton Dee Village, Scotland, July 2013.

151. Interview with a Camphill coworker in Norway, July 2016.

152. Interview with a Camphill coworker in Norway, July 2016.

153. Interview with a Camphill coworker in Scotland, July 2013.

154. Interview with Russ Pooler at Newton Dee Village, Scotland, July 2013.

155. Interview with Tobias Pedersen at Camphill Grangebeg, Ireland, August 2013. 
156. Interview with a Camphill coworker in North America, April 2014.

157. Interview with Guy Alma at Camphil Special School, North America, April 2014.

158. Interview with Russ Pooler at Newton Dee Village, Scotland, July 2013.

159. Interview with Ruairidh von Stein at Botton Village, England, June 2016.

160. Interview with Veronika van Duin at Camphill Holywood, Ireland, July 2013.

161. Interview with Jake Vollrath at Newton Dee Village, Scotland, July 2013.

162. Ibid.

163. Interview with Steffi Hagedorn at Camphill Solborg, Norway July 2016.

164. Interview with a Camphill coworker in England, August 2013. He did acknowledge, though, that this observation is based on conversations with coworkers from just "a handful of places."

165. Interview with a Camphill coworker in Scotland, June 2013.

166. Interview with a Camphill coworker in Scotland, June 2016.

167. Ibid. Interview with a Camphill coworker in Scotland, June 2016.

168. Ibid.

169. Ibid. Interview with a Camphill coworker in Scotland, June 2016.

170. Interview with Hannah Schwartz at Heartbeet Lifesharing, North America, August 2014 .

171. Interview with a Camphill coworker in Norway, July 2016.

172. Interview with Steffi Hagedorn at Camphill Solborg, Norway, July 2016.

173. Ibid.

\section{CAMPHILL CONSTITUENCIES}

1. Interview with Ruairidh von Stein at Botton Village, England, June 2016.

2. "Camphill Scotland," www.camphillscotland.org.uk, accessed August 1, 2018.

3. Newton Dee website, www.camphillscotland.org.uk/community/newton-dee, accessed August 1, 2018.

4. Camphill Association of North America website, "About the Camphill Communities of North America," www.camphill.org/about-camphill, accessed August 1, 2018. Although I could no longer find this passage on the Camphill Association of North America website on May 8, 2020, it did appear on the sites of some individual Camphill places.

5. Camphill School Aberdeen website, "Our Mission, Our Vision, Our Ethos," www .camphillschools.org.uk/general-information/our-mission-our-vision-our-ethos, accessed August 1, 2018.

6. Camphill Village Kimberton Hills website, www.camphillkimberton.org, accessed August 1, 2018; www.camphill.org/communities/kimberton-hills, accessed May 8, 2020.

7. Interview with Veronika van Duin at Camphill Holywood, Ireland, July 2013.

8. Bock, ed., Builders of Camphill; Johannes M. Surkamp, ed., The Lives of Camphill: An Anthology of the Pioneers (Edinburgh: Floris, 2007).

9. Anke Weihs, "Fragments from the Story of Camphill," Camphill Correspondence, May 1975, 2-4; 4.

10. Jens-Peter Linde and Christof Koenig, "Athol Henry Byrne," Camphill Correspondence, November-December 2001, 16-17.

11. Christof Koenig, "David Austin Reid," Camphill Correspondence, July-August 2002, 14.

12. Christof Andreas Lindenberg, "Early Glencraig Memories," Camphill Correspondence, November 1975, 4-5. 
13. Interview with Jonas Hellbrandt at Newton Dee Village, Scotland, July 2016.

14. Interview with a Camphill coworker in Norway, July 2016.

15. Interview with Javier Gonzalez Roa at Tiphereth, Scotland, June 2016.

16. Interview with Ruairidh von Stein at Botton Village, England, June 2016.

17. Interview with Veronika van Duin at Camphill Holywood, Ireland, July 2013.

18. Interview with Javier Gonzalez Roa at Tiphereth, Scotland, June 2016.

19. Interview with a Camphill coworker in Norway, July 2016.

20. Interview with Veronika van Duin at Camphill Holywood, Ireland, July 2013.

21. Interview with Jake Vollrath at Newton Dee Village, Scotland, June 2016.

22. Fran Clay, "What Is a 'Villager'?" Camphill Correspondence, September-October 1990, 15.

23. Andrew Plant, "Experiences of Community Revisited," report shared with the author in January 2020.

24. Interview with Steffi Hagedorn at Camphill Solborg, Norway, July 2016.

25. Peter Roth, "Social Therapeutic Conference," Camphill Correspondence, July 1976, 4.

26. Elisabeth Ameln and Zalene Corey Cooper, "Victor Alvez," Camphill Correspondence, November-December 2001, 14-16.

27. Interview with Jonas Hellbrandt at Newton Dee Village, Scotland, July 2016.

28. Interview with a Camphill coworker in Norway, July 2016.

29. Interviews with people at Camphill Special School, North America, April 2014.

30. Interview with Guy Alma at Camphill Special School, North America, April 2014.

31. Interview with Javier Gonzalez Roa at Tiphereth, Scotland, June 2016.

32. Interview with staffperson at Sólheimar Ecovillage, Iceland, June 2016.

33. Interview with a Camphill coworker in Norway, July 2016.

34. Interview with Vincent Reynolds at Camphill Community Glencraig, Ireland, July 2013.

35. Interview with Jake Vollrath at Newton Dee Village, Scotland, July 2013.

36. Interview with a Camphill coworker in Scotland, June 2016; Valerie Werthman, "Letter from Scotland-1 Newton Dee," Camphill Correspondence, May 1975, 6.

37. Interview with a Camphill coworker in Scotland, June 2016.

38. Interview with Ruairidh von Stein at Botton Village, England, June 2016.

39. Interview with a Camphill coworker in North America, April 2014.

40. Interview with a Camphill coworker in North America, April 2014.

41. Interview with a Camphill coworker in North America, August 2014.

42. Interview with a Camphill coworker in Norway, July 2016.

43. Interview with a Camphill coworker in North America, April 2014.

44. Regine Blockhuys, "A Villagers' Conference in Germany," Camphill Correspondence, July $1976,7$.

45. Erika Opitz, "A Villagers' Retreat at Blair Drummond-Scotland," Camphill Correspondence, November 1976, 8-10.

46. Thomas Weihs, "Conclusion of the Camphill Yearly Report," Camphill Correspondence, May 1975, 5 .

47. Margarete von Freeden, "Our Connections with our Surroundings," Camphill Correspondence, May 1975, 7.

48. Interview with Leslie Fish at the Cascadia Society, North America, July 2015. 
49. Interview with a Camphill coworker in Scotland, July 2013.

50. Interview with Christoph Hanni at Camphill School Aberdeen, Scotland, July 2013.

51. Interview with Marjan Sikkel at Newton Dee Village, Scotland, July 2013, and email correspondence with Marjan Sikkel, March 20, 2018.

52. Interview with a Camphill coworker in North America, April 2014.

53. Interview with Steffi Hagedorn at Camphill Solborg, Norway, July 2016.

54. Interview with a Camphill coworker in Ireland, August 2013.

55. Interview with Guy Alma at Camphill Special School, North America, April 2014.

56. Interview with a Camphill coworker in England, August 2013.

57. Ibid.

58. Interview with Tobias Pedersen at Camphill Grangebeg, Ireland, August 2013.

59. Interview with a Camphill coworker in Ireland, August 2013.

6o. Interview with Jake Vollrath at Newton Dee Village, Scotland, June 2016.

61. Interview with a Camphill coworker in North America, April 2014.

62. Interview with Guy Alma at Camphill Special School, North America, April 2014.

63. Interview with a Camphill coworker in Ireland, August 2013.

64. Interview with Jan Göschel at Camphill Special School, North America, April 2014; interview with a Camphill coworker in North America, April 2014.

65. Interview with a Camphill coworker in Norway, July 2016.

66. Interview with Steffi Hagedorn at Camphill Solborg, Norway, July 2016.

67. Ibid.

68. Interview with Jonas Hellbrandt at Newton Dee Village, Scotland, July 2016.

69. Interview with a young coworker in Ireland, July 2013.

70. Interview with a young coworker in Ireland, July 2013.

71. Coleman Lyles, "Camphill Seminar U.S.A. College Credits?" Camphill Correspondence, April 1976, 10.

72. Email correspondence with Robin Jackson, September 30, 2018.

73. Angelika Monteux, "Curative Education Today," Camphill Correspondence, November-December 2000, 5.

74. Interview with Angelika Monteux at Camphill School Aberdeen, Scotland, July 2013.

75. Interview with Marjan Sikkel at Newton Dee Village, Scotland, July 2013.

76. Interview with a Camphill coworker in Scotland, July 2013.

77. Email correspondence with Robin Jackson, September 30, 2018.

78. Ross Anderson, "RGU launches new course for social care workforce," www.rgu .ac.uk/news/rgu-launches-new-course-for-social-care-workforce, July 7, 2015, accessed February 7, 2018. As one Camphiller explained it in an interview in July 2016, the difference between "social work" and "social pedagogy" is that social workers visit their clients intermittently, while social pedagogues are immersed in the daily life of the people with whom they work.

79. Interview with a Camphill coworker in Scotland, June 2016.

8o. Ibid.

81. Interview with a Camphill coworker in Scotland, June 2016.

82. "Camphill Academy," http://camphill.edu, accessed August 1, 2018.

83. Interview with Carsten Callesen at Camphill Special School, North America, April 2014. 
84. Interview with Jan Göschel at Camphill Special School, North America, April 2014 .

85. Interview with Guy Alma at Camphill Special School, North America, April 2014.

86. Interview with Jan Göschel at Camphill Special School, North America, April 2014.

87. Ibid.

88. Ibid.

89. "Personnel Changes in the Council for Curative Education and Social Therapy," www.en.khsdornach.org/Personnel-changes.532.o.html, accessed February 7, 2018.

90. Interview with Jan Göschel at Camphill Special School, North America, April 2014; interview with a Camphill coworker in Norway, July 2016.

91. Interview with a Camphill coworker in Scotland, June 2016.

92. Interview with Marjan Sikkel at Newton Dee Village, Scotland, July 2013.

93. Interview with Jake Vollrath at Newton Dee Village, Scotland, July 2013.

94. Interview with Jonny Mallam-Clarke at Camphill School Aberdeen, July 2013.

95. Thomas Weihs, "Conclusion of the Camphill Yearly Report," Camphill Correspondence, May 1975, 5.

96. Interview with a Camphill coworker in Scotland, July 2013.

97. Interview with Crispian Villeneuve at Camphill Community Glencraig, July 2013.

98. Interview with Neil Henery at Camphill Scotland, July 2013.

99. Interview with a Camphill coworker in Scotland, July 2013.

10o. Interview with Veronika van Duin at Camphill Holywood, Ireland, July 2013.

101. Interview with Carsten Callesen at Camphill Special School, North America, April 2014.

102. Roth, "Camphill Census: Summer 1976," 4-5; Camphill Association of North America census data provided to author by CANA.

103. Camphill Scotland, "Camphill Scotland Statistics Return 2015," provided to the author by Kristen Hogg.

104. Camphill Scotland, "Report of the Key Findings of the Survey on the Potential Impact of BREXIT on Camhill in Scotland," www.camphillscotland.org.uk/wp-content /uploads/2017/og/Brexit-survey.pdf, accessed July 11, 2018.

105. Interview with a Camphill coworker in North America, April 2014.

106. Interview with Tobias Pedersen at Camphill Grangebeg, Ireland, August 2013.

107. Interview with Steffi Hagedorn at Camphill Solborg, Norway, July 2016.

108. Interview with a Camphill coworker in Scotland, June 2016.

109. Interview with Guy Alma at Camphill Special School, North America, April 2014.

110. Ibid.

111. Hartmut von Jeetze, "Camphill Village Minnesota," Camphill Correspondence, February 1982, 5 .

112. Monteux, "Cairnlee House," 21.

113. Interview with a Camphill coworker in Ireland, August 2013.

114. Interview with Marjan Sikkel at Newton Dee Village, Scotland, July 2013.

115. Interview with a Camphill coworker in North America, April 2014.

116. Peter Woods, "Letter from South Africa," Camphill Correspondence, December $1975,7$.

117. Interview with a Camphill coworker in Scotland, July 2013. 
118. Interview with Russ Pooler at Newton Dee Village, July 2013.

119. Interview with a Camphill community manager in Norway, July 2016; interview with a Camphill community manager in North America, April 2014.

120. Interview with a Camphill community manager in North America, April 2014.

121. Interview with a Camphill coworker in Ireland, July 2013.

122. Interview with a government employee working at a Camphill place in Ireland, July 2013.

123. Interview with a Camphill coworker in Scotland, July 2013.

124. Interview with a Camphill coworker in Scotland, July 2013.

125. Interview with Russ Pooler at Newton Dee Village, Scotland, July 2013.

126. Interview with Fran Pioli at Cherry Orchards Camphill Community, England, August 2013.

127. Interview with Mischa Fekete at The Bridge Camphill Community, Ireland, August 2013.

128. Interviews conducted with four coworkers at a Camphill in North America, July 2015.

129. Interview with a Camphill employee in North America, April 2014.

130. Interview with Adrian Bowden at Camphill Soltane, North America, April 2014.

131. Adrian Bowden, "Camphill Not Service Provider-Community Across the Threshold," Camphill Correspondence, January-February 2018, 12-14.

132. Interview with Ruairidh von Stein at Botton Village, England, June 2016.

133. Interview with a Camphill coworker in Scotland, July 2013.

134. Interview with Veronika van Duin at Camphill Holywood, Ireland, July 2013.

135. Interview with a Camphill employee in Scotland, June 2016.

136. Interview with a Camphill coworker in Scotland, July 2013.

137. Interview with Mischa Fekete at The Bridge Camphill Community, Ireland, August 2013.

138. Interview with an employee at Garvald, Scotland, July 2013.

139. Interview with Diedra Heitzman at Camphill Village Kimberton Hills, North America, April 2014.

140. Interview with Veronika van Duin at Camphill Holywood, Ireland, July 2013.

141. Interview with Mischa Fekete at The Bridge Camphill Community, Ireland, August 2013.

142. Interview with Jake Vollrath at Newton Dee Village, Scotland, June 2016.

143. Interview with Mischa Fekete at The Bridge Camphill Community, Ireland, August 2013.

144. Ibid.

145. Interview with Carsten Callesen at Camphill Special School, North America, April 2014.

146. Interview with Tracey McCoubrey at Camphill Community Glencraig, Scotland, July 2013.

147. Ibid.

148. Interview with Fran Pioli at Cherry Orchards Camphill Community, England, August 2013.

149. Steiner, Curative Education, lectures 7 and 8. 
150. Zoe Brennan-Krohn, "Negotiating the Twentieth Century: A Historical Analysis of Camphill Communities," in Discovering Camphill: New Perspectives, Research, and Developments, ed. Robin Jackson (Edinburgh: Floris, 2011), 28-31.

151. Interview with a Camphill coworker in Scotland, July 2013.

152. Friedwart Bock, "Meg Farquhar," Camphill Correspondence, July-August 2000, 15.

153. "Anne Ratner Concert Series," www.anneratnerconcertseries.org, accessed July 12, 2018.

154. "About the Bowl-a-Thon," www.josephdfreedmanbowlathon.org/about.html, accessed July 12, 2018.

155. Barbara Lipsker, “The New Hall at Glencraig," Camphill Correspondence, June 1975, 10.

156. Cherry Hughes, "Parents' Conference at Glencraig," Camphill Correspondence, August 1976, 13 .

157. Interview with Andrew Plant at Milltown Community, Scotland, July 2013.

158. "Action for Botton," www.actionforbotton.org, accessed July 12, 2018.

159. Interviews, July 2015; email correspondence, June 2018.

160. Leonardo Fulgosi, "Letter from Switzerland," Camphill Correspondence, March $1975,2-4$.

161. Interview with Mischa Fekete at The Bridge Camphill Community, Ireland, August 2013.

162. Camphill Village Trust, www.camphillvillagetrust.org.uk/about-us/our-trustees, accessed June 7, 2019.

163. Interview with a Camphill coworker in England, August 2013.

164. Interview with Stephen Sands at Cherry Orchards Camphill Community, England, August 2013.

165. Interview with Tobias Pedersen at Camphill Grangebeg, Ireland, August 2013, interview with a Camphill coworker in Ireland, August 2013, interview with Mischa Fekete at The Bridge Camphill Community, Ireland, August 2013.

166. Camphill Communities of Ireland, www.camphill.ie/Directors, accessed February 9, 2018.

167. Interview with a Camphill coworker in Norway, July 2016.

168. Camphill School Aberdeen, www.camphillschools.org.uk/general-information /board-of-trustees, accessed February 9, 2018.

169. Camphill Scotland, www.camphillscotland.org.uk/camphill-scotland/trustees -and-governance, accessed February 9, 2018.

170. Interview with a Camphill manager in North America, April 2014.

171. Interview with Diedra Heitzman at Camphill Village Kimberton Hills, North America, April 2014.

172. Interview with Carsten Callesen at Camphill Special School, North America, April 2014.

173. Interview with Diedra Heitzman at Camphill Village Kimberton Hills, North America, April 2014.

174. Interviews with Camphill managers in North America, April 2014.

175. Ibid.

176. Interview with Stephen Sands at Cherry Orchards Camphill Community, England, August 2013.

177. Interview with Mischa Fekete at The Bridge Camphill Community, Ireland, August 2013. 
178. Camphill Scotland, www.camphillscotland.org.uk/camphill-scotland/trustees -and-governance, accessed February 9, 2018.

179. Interview with Camphill managers in North America, April 2014.

180. Andrew Plant, "Cohousing: A Model for Camphill?" available via Camphill Research Network, https://s3-eu-west-1.amazonaws.com/articles-and-essays/Cohousing -A-model-for-Camphill.pdf, accessed July 12, 2018.

181. Email from Philip Curwen, July 15, 2015; see also www.gannicox.org., accessed April 30, 2020.

182. Peter Bateson, “Ten Years of the Camphill Movement," Camphill Correspondence, September-October 2000, 9-12.

183. International Camphill Movement Group, "Statement of Intent from the Groups," www.karl-koenig-institute.net/anhaenge-2016/International_Camphill_Movement _Group_Document_June\%202016.pdf, accessed July 12, 2018.

\section{CAMPHILL CONTEXTS}

1. Penelope Roberts, "Metamorphosis and Being," in A Candle on the Hill, ed. Pietzner, 61.

2. Interview with Jens-Peter Linde at Camphill Scotland, July 2013.

3. Rudolf Steiner, How to Know Higher Worlds, 184-94.

4. Interview with a Camphill coworker in England, August 2013.

5. Interview with a coworker at Garvald, Scotland, July 2013.

6. Rudolf Steiner, "Anthroposophy and the Social Question," part 3, trans. Harry Collison (Spring Valley, NY: Mercury Press, 1982), GA 34. The "fundamental social law" appears in a collection of three essays, first published in 1905-6 in Lucifer-Gnosis. The German title was "Geisteswissenschaft and soziale Frage." English titles include "Anthroposophy and the Social Question," "Spiritual Science and the Social Question," and "The Science of Spirit and the Social Question." Camphiller Richard Steel has identified two earlier occasions on which Steiner said something quite similar. In a Berlin lecture in 1905, he envisioned a "small community" in which participants would pool earnings and draw freely from the common fund, and in an esoteric lesson of 1906 he said that "egoism" is the source of all suffering and that egoism is epitomized in the sentiment that "whatever work I do has to be paid for." Lecture of October 16, 1905; lecture of March 3, 1906 (GA 266/1); cited in Steel, "Inner Legacy of Anthroposophy", 1, 3.

7. Anke Weihs, "The Camphill Community and the Christian Community," Camphill Correspondence, December 1976, 1-3.

8. Interview with Jonas Hellbrandt at Newton Dee Village, Scotland, July 2016.

9. Interview with Angelika Monteux at Camphill School Aberdeen, Scotland, July 2013.

10. Interview with a Camphill coworker in Scotland, July 2013.

11. Interview with a Camphill coworker in Norway, July 2016.

12. Interview with Javier Gonzalez Roa at Tiphereth, June 2016.

13. Interview with Ruairidh von Stein at Botton Village, England, June 2016.

14. Interview with a Camphill coworker in North America, July 2015.

15. Interview with Marjan Sikkel at Newton Dee Village, July 2013.

16. "Goetheanum Meditation Initiative Worldwide," https://goetheanum.co/en/news /meditationsinitiative, accessed May 8, 2020; Arthur Zajonc, Meditation as Contemplative Inquiry: When Knowing Becomes Love (Great Barrington, MA: Lindisfarne, 2008). Zajonc 
is a former general secretary of the Anthroposophical Society in America who has also worked closely with Buddhist organizations inspired by the Dalai Lama.

17. Interview with Marjan Sikkel at Newton Dee Village, Scotland, July 2013.

18. Karl König, "The Three Pillars of the Camphill Movement," in König, Spirit of Camphill, ed. Steel, 108-27; Three Jens-Peter Linde, "Pillars Past, Present and Future," Camphill Correspondence, May-June 2001, 2-3.

19. Correspondence with a longtime Camphiller, May 2018.

20. Interview with Angelika Monteux at Camphill School Aberdeen, Scotland, July 2013.

21. Karl König, "Third Memorandum," in König, History of the Bible-Evening, 9.

22. Karl König, "The Bible Evening Memorandum," October 20, 1965, reprinted in Camphill Correspondence, July-August 2008, 1.

23. Irmgard Lazarus, "The Bible Evening Filmed," Camphill Correspondence, January $1975,8$.

24. Interview with a Camphill coworker in North America, July 2015.

25. Interview with a Camphill coworker in Scotland, July 2013.

26. Interview with Angelika Monteux at Camphill School Aberdeen, Scotland, July 2013.

27. Interview with a Camphill coworker in North America, April 2014.

28. Interview with a Camphill coworker in Norway, July 2016.

29. Interview with Ruairidh von Stein at Botton Village, England, June 2016.

30. Guy Cornish, "Do We Need a New Name for the Bible Evening?" Camphill Correspondence, July-August 2008, 4.

31. Interview with a Camphill coworker in North America, August 2014.

32. Interview with Steffi Hagedorn at Camphill Solborg, Norway, July 2016.

33. Interview with Camphill coworkers in Scotland, July 2013.

34. Interview with a Camphill coworker in Scotland, July 2013.

35. Interview with Stephen Sands at Cherry Orchards Camphill Community, August 2013.

36. Interview with Jake Vollrath at Newton Dee Village, Scotland, July 2013.

37. Interview with Andrew Plant at Milltown Community, Scotland, July 2013.

38. Interview with a Camphill coworker in Scotland, July 2013.

39. Rudolf Steiner, Basic Issues of the Social Question, GA 23, trans. Frank Thomas Smith (Southern Cross Review E-Books), chapter 3.

40. This approach was suggested to me by Christopher Houghton Budd. My interpretation of what I found in the essays is, however, my own, relatively uninfluenced by Budd's writings on social threefolding.

41. Steiner, "Anthroposophy and the Social Question," part 1.

42. Ibid., part 2.

43. König, "Three Stars," in König, Spirit of Camphill, ed. Steel, 102-7.

44. Steiner, "Anthroposophy and the Social Question," part 3.

45. Lecture of March 3, 1906 (GA 266/1), cited in Richard Steel, "The Inner Legacy of Anthroposophy at the Turning Point of the Millennium," Camphill Correspondence, September-October 2000, 1.

46. Steiner, "Anthroposophy and the Social Question," part 3.

47. König, "Three Stars," 106; Steel, "Three Stars, Pillars, and Essentials," in König, Spirit of Camphill, ed. Steel, 74.

48. Steiner, "Anthroposophy and the Social Question," part 3. 
49. Interview with Christoph Hanni at Camphill School Aberdeen, Scotland, July 2013.

50. Interview with Mischa Fekete at The Bridge Camphill Community, Ireland, August 2013.

51. Email correspondence with Penelope Baring, October 4, 2018.

52. Interview with Michael Babitch at Camphill Village Kimberton Hills, North America, April 2014.

53. Richard Steel, ed., Communities for Tomorrow (Edinburg: Floris, 2011).

54. Interview with an anthroposophist who was raised in the Camphill Movement, September 2013.

55. Interview with a Camphill administrator in North America, April 2014.

56. Steiner, Outline of Esoteric Science, GA 13, 276-79.

57. Rudolf Steiner, "Freiheit und Gesellschaft," Magazin für Literatur 67 (1898): 29-30, GA 31, cited in Paul Mackay, "The Anthroposophical Society as a Michael Community," trans. Douglas Miller, Section for the Social Sciences of North America Members' Communication (Fall 2012): 6.

58. Interview with a Camphill coworker in Ireland, August 2013.

59. Interview with Jake Vollrath at Newton Dee Village, Scotland, July 2013.

6o. Interview with Tom Marx at Tigh a'Chomainn Camphill, Scotland, July 2013.

61. Interview with a Camphill coworker in Scotland, July 2013.

62. Interview with Steve Lyons at Camphill Scotland, July 2013.

63. Interview with a Camphill coworker in North America, April 2014.

64. "What Is the Aim of "Ways to Quality'?" www.confidentia.info/index.php/en /audits-and-certifications/ways-to-quality, accessed February 12, 2018.

65. Interview with a Camphill coworker in Scotland, July 2013.

66. Interview with a Camphill coworker in Ireland, August 2013.

67. Interview with a Camphill coworker in Scotland, July 2013.

68. Interview with a Camphill administrator in North America, April 2014.

69. Interview with a Camphill coworker in Ireland, July 2013.

70. Interview with Seb Monteux at Newton Dee Village, Scotland, July 2013.

71. Interview with Marjan Sikkel at Newton Dee Village, Scotland, July 2013.

72. Interview with a Camphill coworker in Scotland, July 2013.

73. Interview with Seb Monteux at Newton Dee Village, Scotland, July 2013.

74. Jens-Peter Linde, "Pillars Past, Present and Future," Camphill Correspondence, May-June 2001, 2-3.

75. König, “Three Stars”; König, “Three Pillars.”

76. JoshuaLockyer, "From DevelopmentalCommunalism to TransformativeUtopianism: An Imagined Conversation with Donald Pitzer," Communal Societies 29/1 (2009): 1-14.

77. Carlo Pietzner, "Children of Israel," Camphill Cresset 5/1 (Michaelmas 1958): 22-23; Marrianne Sander, “Impressions of the Kibbutzim," Camphill Cresset 5/1 (Michaelmas 1958): 29.

78. Karl König, "Integration in Medicine," Coracle (1942): 19-31.

79. Karl König, "The Birth of a Movement," in Spirit of Camphill, ed. Steel, 167-68; Anke Weihs, "Fragments from the Story of Camphill 1939-1940," part 4, Camphill Correspondence, August 1975, 3.

8o. Informal conversation with Helen Zipperlen at Camphill Village Kimberton Hills, North America, 27 July 2018. 
81. Karl König as paraphrased by Anke Weihs, "Fragments from the Story of Camphill 1939-1940," part 2, Camphill Correspondence, June 1975, 3.

82. Karl König, "The Three Great Errors (A Chapter in Community Living)," Cresset 3/1 (Michaelmas 1956): 16.

83. KoinoniaFarm, "HistoryTimeline:KoinoniaFarm,"www.koinoniafarm.org/koinonia -history-timeline, accessed July 30, 2018.

84. Udi Levy and Gilad Goldshmidt, "Bible Studies and Lessons in Arabic," Freunde Waldorf, www.freunde-waldorf.de/en/the-friends/publications/waldorf-education-worldwide /teil-2/israel, accessed July 30, 2018.

85. Judith Jones, "L’Arche," Camphill Correspondence, December 1975, 4-5.

86. Nick Blitz et al., "The Evolving Practice of Lifesharing in Ireland," Camphill Correspondence, November-December 2008, 13-14; Patrick Lydon, "Working in Partnership, Part II," Camphill Correspondence, January-February 2000, 1.

87. Jan Bang, "New Forms in Architecture and Community," Camphill Correspondence, July-August 2002, 4.

88. Eric Hoyland, "A Possible 'Third Way' for Some Intentional Communities Which Have Developed on Rural Estates," Camphill Correspondence, March-April 2007, 8.

89. "Hertha Living Community," at www.hertha.dk/?option=com_content\&view= article\&id=73\&Itemid=256, accessed June 28, 2019; "Hertha Living Community: Social and Cultural Value Creation in a Village of the Future," www.hertha.dk/images/Hertha Brochure2016_eng_Stor.pdf, accessed May 8, 2020.

90. C.A. Mier, "Agriculture and the Village Community," Cresset 3/1 (Michaelmas 1956): 27 .

91. Editorial, Cresset 3/1 (Michaelmas 1956): 5 .

92. Karl König, "Address at the Founding of the Lake Constance Group of Farmers and Gardeners," September 4, 1964, in Karl König, Social Farming: Healing Humanity and the Earth, ed. and trans. Richard Steel and Simon Blaxland de Lange (Edinburgh: Floris, 2014), 67-68.

93. Baruch Urieli, quoted in Margarete von Freeden, "Towards the Forthcoming Village Conference," Camphill Correspondence, May 1975, 11-12.

94. Richard Poole, "Islands of Recovery," Camphill Correspondence, July 1975, 2.

95. Hartmut von Jeetze, "Agriculture and the Camphill Movement," Camphill Correspondence, July 1975, 6-8.

96. Interview with Jonathan Reid at Botton Village, England, June 2016.

97. Interview with a Camphill coworker in Norway, July 2016.

98. Interview with Will Browne at Camphill Vidaråsen, Norway, July 2016.

99. Interview with Ruth Tschannen at Cascadia Society, North America, July 2015.

100. Interview with a Camphill coworker in England, June 2016.

101. Interview with Runa Sophia Evensen Gafni at Camphill Vidaråsen, Norway, July 2016.

102. Gunther Lehr, "Bee-House of Beitenwil," Camphill Correspondence, April 1975, 6-7.

103. Interview with a staffperson at Sólheimar Ecovillage, Iceland, June 2016.

104. Karl König, "Detailed Plan for the Development of a Curative Institute," in Karl König, My Task: Autobiography and Biographies, ed. Peter Selg (Edinburgh: Floris, 2008), $160-61$. 
105. König, “Three Great Errors," 10.

106. T.J. Weihs, "An Appreciation of the Village Community," Cresset 1/3 (Michaelmas 1956): 22-23.

107. David L. Braddock and Susan L. Parish, "An Institutional History of Disability," in Handbook of Disability Studies, ed. Gary L. Albrecht, Katherine D. Seelman, and Michael Bury (Thousand Oaks, CA: Sage Publications, 2001), 11-68.

108. Karl König, "The Human Factor," February 1956, reprinted in Camphill Correspondence, March 1976, 1-2.

109. Cited in Peter Roth, “Integration," Camphill Correspondence, September 1975, 8.

110. Mencap, "Mencap's History," www.mencap.org.uk/about-us/mencaps-history, accessed March 7, 2018.

111. Wolf Wolfensberger, "Social Role Valorization: A Proposed New Term for the Principle of Normalization," Intellectual and Developmental Disabilities 49/6 (December 2011): 435-40; Helen Zipperlen and John O'Brien, Cultivating Thinking Hearts: Letters from the Lifesharing Safeguards Project (Kimberton, PA: Camphill Village Kimberton Hills, 1994).

112. Richard Poole, editorial in Camphill Correspondence, September 1975, 2.

113. Jeff Balls, "Integration," Camphill Correspondence, September 1975, 7-8.

114. Cited in Roth, "Integration," 8-9.

115. Oliver, Understanding Disability, 87-105. For a more irenic account of the relationship between normalization theory and the social model of disability, see David Race, Kathy Boxall, and Iain Carson, "Towards a Dialogue for Practice: Reconciling Social Role Valorization and the Social Model of Disability," Disability and Society 20/5 (2005): 507-21.

116. Jürgen and Erika Nauck, "Integrating Camphill with the Urban Community," Camphill Correspondence, July 1976, 5 .

117. Ivan Jacobson, "Letter from Norway," Camphill Correspondence, May 1976, 3-4.

118. Anne Langeland, "Integration: Village and Local Community" Camphill Correspondence, September 1975, 11.

119. Interview with a Camphill coworker in Ireland, August 2013.

120. Peter Bateson, "Address at the Official Opening of Watch Oak Farm," Camphill Correspondence, September-October 1993, 19.

121. "Cherry Orchards," Camphill Correspondence, September-October 1995, 11.

122. Patrick Lydon, "Working in Partnership, Part II," Camphill Correspondence, January-February 2000, 1-3.

123. Interview with Tobias Pedersen at Camphill Grangebeg, Ireland, August 2013.

124. Interview with a government employee working at a Camphill place in Ireland, July 2013.

125. Interview with a Camphill coworker in Ireland, July 2013.

126. Interview with Angelika Monteux at Camphill School Aberdeen, Scotland, July 2013.

127. Interview with Neil Henery at Camphill Scotland, July 2013.

128. Interview with Tom Marx at Tigh a'Chomainn Camphill, Scotland, July 2013.

129. Interview with Stephen Sands at Cherry Orchards Camphill Community, England, August 2013.

130. Interview with Vincent Reynolds at Camphill Community Glencraig, Ireland, July 2013. 
131. Interview with Diedra Heitzman at Camphill Village Kimberton Hills, North America, April 2014.

132. Interview with a Camphill coworker in Scotland, July 2013.

133. Interview with a Camphill coworker in Ireland, July 2013.

134. Interview with Neil Henery at Camphill Scotland, July 2013.

135. Interview with a Camphill coworker in Scotland, July 2013.

136. Interview with a Camphill coworker in Scotland, July 2013.

137. Interview with Tobias Pedersen at Camphill Grangebeg, Ireland, August 2013.

138. Interview with a Camphill coworker in Scotland, July 2013.

139. Interview with a Camphill coworker in Ireland, August 2013.

140. Interview with a Camphill coworker in Ireland, August 2013.

141. Interview with a Camphill coworker in Scotland, July 2013.

142. Interview with a Camphill coworker in Scotland, July 2013.

143. Interview with Jonny Mallam-Clarke at Camphill School Aberdeen, Scotland, July 2013.

144. Interview with Christoph Hanni at Camphill School Aberdeen, July 2013.

145. Interview with a government employee working at a Camphill place in Ireland, July 2013.

146. Interview with a long-time Camphiller in North America, April 2014.

147. Interview with Jonathan Reid at Botton Village, England, July 2016.

148. Interview with Simon Beckett at Newton Dee Village, Scotland, July 2013.

149. Interview with Christoph Hanni at Camphill School Aberdeen, Scotland, July 2013.

150. Interview with Tom Marx at Tigh a'Chomainn Camphill Community, Scotland, July 2013.

151. Interview with a Camphill coworker in Scotland, July 2013.

152. Interview with a Camphill coworker in Ireland, July 2013.

153. Colin Barnes, "Understanding the Social Model of Disability: Past, Present, and Future," in Routledge Handbook of Disability Studies, ed. Nick Watson, Alan Roulstone, and Carol Thomas (London: Routledge, 2012), 12-29.

154. König, "Three Great Errors," 6-16.

155. Julian Sleigh, quoted in Margarete von Freeden, "Towards the Forthcoming Village Conference," Camphill Correspondence, May 1975, 12.

156. Andy Rickell, cited in Simon Rawles, "Fringe Benefits," The Guardian, March 31, 2004, reprinted in Camphill Correspondence, July-August 2004, 5.

157. Helen Meekosha and Russell Shuttleworth, "What's So 'Critical' about Critical Disability Studies?" in Lennard J. Davis, The Disability Studies Reader, 5th ed. (New York: Routledge, 2017), 175-94; Tom Shakespeare, "The Social Model of Disability," in Davis, Disability Studies Reader, 195-203; Gareth Williams, "Theorizing Disability," in Albrecht, Seelman, and Bury, Handbook, 123-44.

158. Lennard Davis, "Disability, Normality, and Power," introduction to Davis, Disability Studies Reader, 13; David T. Mitchell with Sharon L. Snyder, The Biopolitics of Disability: Neoliberalism, Ablenationalism, and Peripheral Embodiment (Ann Arbor: University of Michigan Press, 2015), 3.

159. Rosemarie Garland-Thomson, "Integrating Disability, Transforming Feminist Theory," in Davis, Disability Studies Reader, 362-63. 
160. Eva Feder Kittay, Learning from My Daughter: The Value and Care of Disabled Minds (New York: Oxford, 2019).

161. James I. Charlton, Nothing about Us without Us: Disability Oppression and Empowerment (Berkeley: University of California Press, 1998), 6.

162. Autistic Self-advocacy Network website, http://autisticadvocacy.org/, accessed July $16,2018$.

163. Jack Reed, "What Is Advocacy? What Is Its Relevance for Camphill?" Camphill Correspondence, July-August 2002, 9.

164. Julia Wolfson, "Snakes and Ladders: Emergence of Deep Power in Transformational Change," PhD diss., Australian National University, 2013, 181-82, available online at www .iapop.com/wp-content/uploads/2018/o1/Snakes-and-Ladders-Emergence-of-Deep-Power -in-Transformational-Change-Julia-Wolfson-PhD.pdf, accessed July 16, 2018.

165. Chuck Kyd, "Camphill International Dialogue," Camphill Correspondence, July-August 2005, 15.

166. Chuck Kyd, "Finding My Voice: A Conference with Villagers and Companions from Camphill Communities in North America," Camphill Correspondence, NovemberDecember 2006, 14-15.

167. Ibid.

168. Wolfson, "Snakes and Ladders," 7.

169. Julia Wolfson, "Influences: Rudolf Steiner," Turning Forward website, http://turning forward.org/paradigm/influences/, accessed July 16, 2018. As of May 8, 2020, the Turning Forward website no longer includes a section about the influence of Rudolf Steiner, though it does feature information about many workshops held at anthroposophical initiatives.

170. Wolfson, "Snakes and Ladders," 16.

171. Ibid., 158-59.

172. Interview with Jonathan Reid at Botton Village, England, July 2016.

173. Interview with Mischa Fekete at The Bridge Camphill Community, Ireland, August 2013.

174. Simon Figg, "One More Step," Camphill Correspondence, May-June 2000, 14.

175. Paraphrased in Patrick Lydon, "Working in Partnership, Part II," Camphill Correspondence, March-April 2000, 3.

176. Wolfson, "Snakes and Ladders," 173-74; email correspondence with a Vidaråsen coworker, July 2018.

177. Interviews with two Camphill coworkers in Norway, July 2016.

178. Wolfson, "Snakes and Ladders," 175-77.

179. Interview with a Camphill coworker in Norway, July 2016.

180. Ibid.

181. Ibid., July 2016.

182. Interview with Will Browne, July 2016; email correspondence, July 2018.

183. Email correspondence, July 2018.

184. "Mediated Settlement Press Release," February 1, 2018, www.actionforbotton .org/cms/tinymce/plugins/moxiemanager/data/files/mediated\%2osettlement\%2opress \%2orelease.pdf, accessed July 19, 2018.

185. "Action For Botton," www.actionforbotton.org, accessed July 19, 2018. 
186. "Esk Valley Camphill Community," www.eskvalleycamphill.org, accessed July 19, 2018.

187. "The Avalon Group," www.avalongroup.org.uk, and "Launch of Botton Shared Lives," May 1, 2018, www.avalongroup.org.uk/news/109/23/Launch-of-Botton-Shared -Lives.html, accessed July 19, 2018. The Botton press release appeared on the second page reached by a small tab for "latest news," implying that it will become increasingly hard to find as time passes.

188. "Final Rule Medicaid HCBS," www.medicaid.gov/sites/default/files/2019-12 /final-rule-slides-01292014.pdf, accessed May 8, 2020; Elizabeth J. Sanders, "Emerging Regulatory, Judicial, and Legislative Changes and Their Implications for the Camphill Movement in the United States," presented at Camphill Research Symposium, July 2016.

189. "Guidance on Settings That Have the Effect of Isolating Individuals Receiving HCBS from the Broader Community," www.medicaid.gov/medicaid/hcbs/downloads /settings-that-isolate.pdf, accessed July 1, 2018; Sanders, "Emerging Regulatory," 31.

190. Together for Choice, "About Us," www.togetherforchoice.org/about-us, accessed August 3, 2018. Adroit lobbying by Camphill Scotland ensured that a similar provision would be written into Scotland's guiding legislation on the regulation of care in 2001. Email correspondence with Robin Jackson, September 30, 2018.

191. Informal conversation with a longtime Camphiller in North America, July 2018.

\section{CONCLUSION}

1. Steiner, Basic Issues of the Social Question, chapter 3, GA 23.

2. Interview with Veronika van Duin at Camphill Holywood, Ireland, July 2013. 


\section{N D E X}

Aberdeen Circle, 145

Aberdeen University, 70, 73, 105-106

abuse, 95, 99, 181, 183-84, 190-92, 196-98

Act of Consecration of Man, 95, 146, 149

Action for Botton, 132-33, 200-201

Adams, David, 34

Advent, 23, 28, 86

Ahriman, 184-85, 204

Alanus, 109

alchemy, 53

Alma, Guy, 62, 68-69, 90, 99, 101, 108, 114

Alvez, Victor, 88-89

Amana, 17, 162

Amann, Trude, 12, 31

Amann, Willi, 12, 33

Americans with Disabilities Act (1990), 188

Americorps, 103

anarchism, 157

Anthroposophic Council for Inclusive Social Development, 109, 155

anthroposophy, 2, 5, 8, 140-61; anthroposophical medicine, 9, 27, 105-106; Anthroposophical Society, 11, 30, 33, 51-54, 67-68, 75-76, 138, 143, 155-56, 215n89; and architecture, 9; and BA programs, 105-106, 108-109; and Camphill coworkers, 48-49, 52-56, 59, 67-68, 70, 74, 77, 79, 111-112, 117; and Camphill employees, 120-23, 126, 128; and Camphill's future, 3, 204-207; and Camphill seminar, 104; and curative education, 10, 23, 27-29, 36,
141-43; definition of, 9, 18, 144, 154; and disability, 88, 95-96, 141-43, 175-76; and karma, 15-16, 46, 59-60, 63-64, 122, 141-43, 187 Antioch College, 47, 164 Antioch University, 107 ashrams, 4, 17 austerity, 179-81, 199-200 Autism Self-Advocacy Network, 190-91, 202-204 Avalon Group, 201

BA programs, 58, 70, 73-74, 104-110, 116, 219n78 Babitch, Michael, 48-49, 53, 155 baby boomers, 25-26, 41-58, 114; and Bible Evening, 146-47; and the Christian Community, 149; and elder communities, 62-63; and environmentalism, 172; and Gen-Xers, 61; and millennials, 65, 68, 72-73, $76,78-79,81-82,98,110$

Balls, Jeff, $177-78$

Ballytobin, 13, 99, 168

Bang, Jan, 169

Bard College, 46

Baron, Steven, 105

Bateson, Peter, 180

Baum, Alex, 12

Beaver Run (Camphill Special School), 13; and Beaver Farm, 44; and Bible Evening, 147; board of, 136; and Camphill Academy, 107-108; and day students, 89-90, 147; and employees, 100-101, 114-15; and inner 
community, 68; and Wildfeuer, Sherry, 46, 50; and Wolf, Bernie, 47; and young coworkers, 111

Beckett, Simon, 58, 187

Beeforth, Judy, 192

Beissel, Conrad, 162

Beitenwil, 174

Bergel, Peter, 85

Bettelheim, Bruno, 47

Bible Evening, 33-34, 56, 66-67, 90, 144-50, 163, 173

Biesantz, Hagen, 155

biodynamics, 9; and Byrne, Athol Henry, 86; and environmentalism, 169-71, 173, 175; and Myrin, Alarik and Mabel, 141; and Pedersen, Tobias, 100; and von Jeetze family, 29; and Wildfeuer, Sherry, 50, 78

Blair Drummond, 96, 124

Blau, Trude. See Amann, Trudi

Blavatsky, Helena, 9

Blockhuys, Regine, 96

board members, 81-82, 93-94, 117-18, 133-39

Botton Village, 10, 12, 36-39, 42; and baby boomers, 47-54, 56; and Bible Evening, 147-48; and Camphill Village Trust, 133; and Community Circles, 69; crisis of, 13, 132, 199-201; and the Croft, 43, 90; and disability policy, 178, 186-87, 194; employees at, 122; and environmentalism, 170-75; and König, Karl, 166, 176; parents at, 132; villagers at, 85-86

Bowden, Adrian, 122

Boyd, Bill, 48

Brachenreuthe, 13, 35

Brexit, 124, 199

Bridge, The, 43, 82, 121, 123-24

British Council of Disabled People, 188

British Disability Discrimination Act (1995), 188

British Trust for Conservation Volunteers, 172

Brook Farm, 202

Browne, Will, 172-73, 197-98

Bruckfelden, 35

Bruderhof, 37, 161, 164

Buchanan, Averil, 32

Budd, Christopher Houghton, 224n 40

Buddhism, 18-19, 23, 47, 52, 89

bureaucratization, $3,20,26,54,100,114-15,118$, 181-87, 204-205

Byrne, Athol Henry, 86

Cabet, Étienne, 17

Cairnlee, 40, 44, 63, 148

Callan, 4, 82

Callesen, Carsten, 111, 126, 136
Calvert, Susan, 39

Camphill Movement: BA programs in, 58, 70, 73-74, 104-110, 116, 219n78; Camphill Academy, 8, 13, 107-110, 155; Camphill Association of North America, 8, 57, 78, 83, 133-34, 136, 192, 201; Camphill Communities of Ireland, 7, 133, 135-36; Camphill School Aberdeen, 10, 12, 27, 31-35, 44, 63, 69, 83, 86, 97, 98, 104-105, 128, 131, 135; Camphill Scotland, 46, 59, 83, 104-105, 134-35, 158-59, 182, 230n190; Camphill Village Trust (England), 6, 13, 38, 73, 90, 99, 112, 122, 132-34, 183, 199-201; Camphill Village Trust (Norway), 7, 100, 133-135; conferences of, 52-53, 75-76, 96-97, 132; and disability, 2, 14-15, 17-18; essentials of, 11 ; founding of, 10 , 26-35, 83, 130; future of, 205-207; generational dynamics of, 18-21, 23, 25-82, 140; inner community of, 32-33, 41, 51-52, 54, 60-62, $68-69,83,129$; members with disabilities, 81-97; Memoranda, 33-34, 146-47; Movement Group, 138; numbers of participants, 8, 42, 57, 112, 209n4; schools, 31-32, 81-86; seminar of, $12,32,36,40-41,46,49,58,60,65-66,74$, 103-104, 107-108, 127-28; spirituality of, 1-2, $15,22-23,27-28,48-49,55,77,79,89$; town communities, 42-43, 203; training colleges, $13,42,44-45,63,65,92,124$, 137; village communities, 36-39, 86-97

Camphill places. See Ballytobin, Beaver Run (Camphill Special School), Beitenwil, Blair Drummond, Botton Village, Brachenreuthe, Bridge, Bruckfelden, Cairnlee, Callan, Camphill School Aberdeen, Cascadia, Cherry Orchards, Christophorus, Clanabogan, Copake (Camphill Village USA), Delrow, Devon, Duffcarrig, Esk Valley, Föhrenbühl, Friends of Camphill India, Gannicox, Ghent, Glencraig, Grange, Grangebeg, Heartbeet Lifesharing, Heathfield Cottage, Hermannsberg, Hermanus, Hogganvik, Holywood, Hudson, Kimberton Hills, Lehenhof, Loch Arthur, Milltown, Minnesota, Mount, Mourne Grange, Murtle, Newton Dee, Nottawasaga, Oaklands Park, Pahkla Camphilli Kula, Peaceful Bamboo Village, Pennine, Perceval, Ringwood, Sadhana Village, Saint Christopher's School, Sheiling Schools, Simeon, Solborg, Soltane, Stourbridge Houses, Svetlana, Thornbury, Tiphereth, Triform, Vidaråsen

Canada, 12, 97, 133, 162. See also Cascadia, Nottawasaga 
care in the community, $83-84,176-80,201-204$

Cascadia, 47, 120, 132, 173

Catholic Worker, 3, 5, 17, 164

Cellars at Jasper Hill, 76

Celo, 17, 164

Centers for Medicare and Medicaid Services, 201-204

Ceresole, Pierre, 48

charitable incorporation, 137

Cherry Orchards, 71, 119-20, 128-29, 134-35, 180, $182-83$

Christ, 67, 173, 184

Christian Community, 2, 9, 131; and Camphill's founding, 33-34, 143; and coworkers, 48, 55, 62; declining significance of, 66; liturgies of, 146, 149-50; and villagers, 39, 86, 95

Christophorus, 12

Clanabogan, 39, 66, 86, 175

Clay, Fran, 88

Coalition for Community Choice, 202-203

cohousing, 5, 137, 168-70

college meetings, 141-42, 145, 163

Comenius, Amos, 29, 152, 161, 163

communal studies, 14, 16-19

Communal Studies Association, 16

communalism, 5, 22-23, 37, 39, 157, 161-70, 202, 205-207

Community Circles, 69

Community Homestead, 69-70, 136

Copake (Camphill Village USA), 1, 13, 39-40; board of, 137; and Camphill Academy, 108; and Camphill Ghent, 63; and Camphill Village Minnesota, 58; and Morgan family, 164-65; and parents, 82, 131; and Sadhana Village, 65; and Schwartz, Hannah, 74; and von Jeetze, Hartmut, 171

Correspondence, 53, 92-93, 148, 174, 196

Council for Quality and Leadership, 94

coworkers. See lifesharing coworkers, young coworkers

creative symbiosis, 3, 19-20; at Camphill, 72, 74, 76, 129-30, 132-33, 138-39, 199-201 205-207; in communalism generally, 5, 16, 18, 167-70; and environmentalism, 174

creative traditionalism, 78-79

Cresset, 53

Cresset House, 115

Croft, 43, 90-91

Crowley, Kristin, 76

curative education, 10-12, 27-29, 130, 141-43; and agriculture, 170-71; and Camphill Academy, 107-108; and Camphill schools, 32, 35-37; and Camphill seminar, 36, 40, 104
Darré, Richard Walther, 30

Darwinism, 15, 37

day programs, $10,57,85,89-90,178$

deinstitutionalization, $5,42,49,85,176-78$

Del Vasto, Lanzo, 168

Delrow, 201

Deshpande, Vasant, 65

developmental communalism, 16, 18-19, 167-70

Devon, 49, 172-73, 182

disability, 2-3, 4-5; anthroposophical understanding of, 141-43; Camphillers with disabilities, 81-97; coworker interest in, 67; terminology for, 209n1; and theology, 15-16, 23

disability policy, 21-22, 32, 36, 44, 100, 115-16, 175-95

disability rights, 5, 14-15, 20-22, 37, 94, 187-95, 197, 202-203

disability studies, 14-16, 20, 23, 178

Doctors without Borders, 108

Down syndrome, 142, 191

Duffcarrig, 38

Dylan, Bob, 50

ecovillages, 5, 110, 168-69, 174-175, 202

elder communities, 13, 56, 62-63, 137

Emerson, Ralph Waldo, 23

Emerson College, 109

employees, 57, 62, 64, 73, 79, 81-82, 99, 112-30

Engel, Margit, 54, 64, 76

England: Camphill places in, 12-13, 32, 42, 44, $56,63,132,137,170,199$; and Camphill Village Trust, 6, 38, 73, 90, 99, 112, 133; evolution beyond community, 72-74, 99-100, 112; and Sunfield, 28; social care policy in, 49, 181-183. See also Botton Village, Cherry Orchards, Croft, Delrow, Devon, Esk Valley, Gannicox, Grange, Heathfield Cottage, Mount, Oaklands Park, Pennine, Ringwood, Saint Christopher's, Sheiling Schools, Stourbridge Houses, Sunfield, Thornbury

environmentalism, 170-75

Ephrata Cloister, 162

epoch of the consciousness soul, 156-57, 194

Esk Valley, 13, 133, 200-201

Eurasia Association, 65

evolving beyond community, 13, 19-20, 162, 167-70, 205-207; and boards, 138-39; at Botton Village, 132-33, 199-201; and employees, 129-30; and millennials, 72-73, 77; and Wolfson, Julia, 193

Excelsior College, 107 
Farquhar, Alistair and Meg, 131

Fekete, Mischa, 43, 121, 123-26, 154, 195

Fellowship Community, 63

Fellowship for Intentional Community, 17, 164

Festival of Offering, 55, 95, 146, 149

festivals, 2, 4, 9, 95-96, 150; and anthroposophy, 149-50; changes in, 90, 184; and coworkers, $101,102,112$; and disability, 21, 31, 83, 93;

and employees, 120-21, 124, 127-28, and parents, 132

Final Rule, 201-204

Findhorn, 47

First Memorandum, 12, 33-34

Fish, Leslie, 98

flowforms, 172-73

Föhrenbühl, 35

Foster, Angie, 76

founding generation, 12, 26-35, 83, 130, 160, 186

Fourier, Charles, 17, 23, 202

Freedman family, 131

Freunde der Erziehungskunst, 60

Friends of Camphill India, 4, 65

Fundamental Social Law, 11, 98, 113, 121, 143-45, $150-55,163,223 n 6$

Gafni, Runa Sophia Evensen, 174

Gandhianism, 17, 168

Gannicox, 134-35, 137

gap year volunteers, 57, 60, 67, 69, 73, 102-103, 110. See also young coworkers

Gardner, Gwen, 47

Garvald, 33, 124, 142, 213n25

generations, $18-21,23,25-82,140$

Gen Xers, 58-65, 81-82

Germany, 11-13, 27, 30, 52, 99, 132, 141, 151, 164; and BA programs, 108-109; Camphill beginnings in, $35,38,39$, 64 ; charitable incorporation in, 133; coworkers from, 40, $60,70,111,124,163$. See also Brachenreuthe, Bruckfelden, Föhrenbühl, Hermannsberg, Lauenstein, Lautenbach, Lehenhof

Gerstler, Sali. See Lipsker, Barbara

Geuter, Fried, 28

Ghent, 63

Gilbert, Jonathan, 74

Gleed family, 32

Glencraig, 12, 38-39; and baby boomers, 46, 50; and employees, 127-128; and International Voluntary Service for Peace, 48; and parents, 131; and social care authorities, 183, 187; and students with complex needs, 91-92; and villagers, 86; and young coworkers, 103, 111
Goetheanum, 52, 109, 156

Goetheanum Meditation Initiative, 145

Gonzalez Roa, Javier, 87, 90, 144-45

Göschel, Jan, 107-109, 155

Grange, 46-47, 63, 201

Grangebeg, 59, 113

Grimm, Rüdiger, 155

Gross National Happiness, 65

Ha Vinh Tho, 13, 65

Hagedorn, Steffi, 70-71, 77, 88, 98-99, 101-102, 148

Hanni, Christoph, 52, 98, 154, 186-187

Harduf, 168

Harmonists, 17, 162

Haughton, Theodore and Emily, 30-31, 212n17

Hauser, Kaspar, 2

Heartbeet Lifesharing, 1, 74-79, 82, 94-95, 132,148

Heathfield Cottage, 13, 42

Heitzman, Diedra, 125, 136, 183-84

Hellbrandt, Jonas, 58, 89, 102, 144

Henery, Neil, 59, 111, 182, 184

Hermannsberg, 39

Hermanus, 13, 86

Hertha Living Community, 170

Hess, Rudolf, 30

High Mowing Organic Seeds, 76

hippies, 46-47, 50, 168, 202

Hitler, Adolf, 30, 37, 140, 142

Hogganvik, 64, 178-79

Holistic Approach to NeuroDevelopment, 79

Holywood, 43, 87

Hoyland, Eric, 170

Hudson, 43

Hus, Jan, 10, 29, 161

Hutterites, 161-62

Huxley, Aldous, 37

Imegwu, Roswitha, 65

immigration, 103-104, 114, 124-25

incomesharing, 11, 21, 97-99, 101-102, 127-28; controversies over, 13, 20, 113, 115-18, 122-24, 180-81, 183-84, 186, 192-94, 197-201; and disability, 89; and First Memorandum, 33-34; and Fundamental Social Law, 121-22, 143-145, 150-55, 159-6o; at Koinonia, 167; and millennials, $71-74,77-79$

India, 4, 13, 17, 38, 65, 162

individualization, 154-60, 179-80, 184-87, 194-95, 204

inner community, 12, 32-35, 41, 69, 82, 206; and anthroposophy, 144-47; and baby boomers, 
51-52, 54-55; and boards, 138; and employees, 129, 195; and Gen-Xers, 58, 60-62, 68-69; and millennials, 58, 68-69, 79, 83; and villagers, 95

institutions, 2-3, 5, 17, 20, 196; and disability, 14, $16,21-22,32,36,42,83-85,89,113,169$; and social care policy, 100, 175-77, 201-204. See also deinstitutionalization

intelligence testing, 14, 37, 176, 188

intentional communities, 5, 16-19, 161-70; and baby boomers, 46, 55; Camphill as, 1, 4, 83-85, 90, 100, 113; and charitable incorporation, 137; and disability, 21-23, 93-94, 99, 132, 176, 178-79, 185-89, 194-95, 199, 201-207; and environmentalism, 172; and Fundamental Social Law, 152-55; and millennials, 67; and Sociological Law, 157-58; and Threefold Community, 53, 63; and young coworkers, 110

International Communal Studies Association, vii, 16

International Voluntary Service for Peace, 48 Iona, 37, 164, 167

Ireland: Camphill Communities of Ireland, 7 , 133, 135-36; Camphill places in, 4, 13, 32, $35,38,43,59,82,86,87,91,99,121,123,131$; employees, 112; and König, Karl, 175; and L'Arche, 168; managers, 118; social care policy in, 181, 183, 185. See also Ballytobin, Bridge, Callan, Clanabogan, Duffcarrig, Glencraig, Grangebeg, Holywood, Kilkenny Center for Arts Talent, Mourne Grange

Jackson, Robin, 191 Janzen, Donald, 16 Jones, Judith, 168

Judaism, 10, 15, 26-27, 29-30, 85, 95, 163-64, 166

karma, 15-16, 46, 59-6o, 63-64, 122, 141-43, 187

Kelpius, Johannes, 162

Kfar Rafael, 168

kibbutzim, 3, 5, 17, 19-20, 47, 161, 163-64, 167-68

Kilkenny Collective for Arts Talent, 4

Kimberton Hills, 44, 74, 78, 83, 113, 125, 135-37, 177,186

Kirkton House, 12, 30-31, 85, 166

Koinonia, 164, 167

Kolisko, Eugen, 30

König, Karl, 10-16, 25-38, 40-41; and agriculture, 170-71; and anthroposophy, 23, 155; and Bible Evening, 146-47; and Camphill's future, 195, 210n11; and Christian
Community, 143, 146; and Cresset, 53; death of, 53,82 ; and disability, $175-76,188$; and Garvald, 124; influence on coworkers, 46, $68,91,105,144$; and Iona, 164; and refugee experience, 165-66; and Robert Owen, 152-53; and refugee experience, 165-66; and Rosicrucians, 163; as spiritual researcher, 141-42, 143-44, 155; and three pillars, 145

König, Tilla, 10, 12, 23, 27-31

Korach, Marie, 12, 31, 35

Kyd, Chuck, 192

L'Arche, 18, 23, 83-85, 129, 168, 177

Lauenstein, 12, 27-29, 40

Lautenbach, 96

leaving money, 79, 101-102

Lehenhof, 3-4, 39, 82

lesser guardian of the threshold, 142

Lievegoed, Bernard, 28

lifesharing, 11, 83, 123-27, 129-30, 143; and abuse, 191; and BA programs, 110; controversies over, 13, 20, 90, 115-18, 132-33, 148, 158-6o, 18o-81, 183-84, 186, 193-204; and First Memorandum, 33-34; and Hertha, 170; and L'Arche, 168; and millennials, 72, 74, 77-79, and villagers, 89, 91

lifesharing coworkers, 45, 57, 81-82, 97-102, $112-17,119-20,122,135,137-38$

Linde, Jens-Peter, 66-67, 86, 142, 161

Lipsker, Barbara, 12, 35, 41, 46, 69, 206

Lissau, Rudi, 12

Loch Arthur, 88, 113

Lockyer, Joshua, 163

Lucifer, 184-85

Lueder, Granny, 50

Lydon, Patrick, 168, 180

Lyons, Steve, 50, 57, 158-59

Maasberg, Tilla. See König, Tilla

Mackay, John Henry, 157

MacLeod, George, 164

Macmillan, Alistair and his family, 10, 31-32, 36, $39,85-86,131,171$

Mal, Kumar, 65

Mallam-Clarke, Jonny, 11, 110-111, 186

managers, 54, 71, 99-101, 117-18, 120, 124, 126, 176, 197-201

Martin of Tours, 159

Marx, Karl, 20, 151-52, 202

Marx, Tom, 61, 157-58, 182, 187

Marxism, 15-16

Mencap, 176-77 
Mental Deficiency Act (1913), 176

Mental Health Act (1959), 176

McCoubrey, Tracey, 127-28

Michaelgarden, 28

millennials, 25, 65-79, 81-82, 102, 110

Milltown, 150

Mindell, Arnold, 193

Minnesota (Camphill Village Minnesota), vii, 5 , 40, 58-59, 92, 113-14, 136, 149

monasticism, 18-20, 23, 212n17

Montessori education, 47

Monteux, Angelika, 105, 144, 146-47, 182

Monteux, Seb, 16o-61

Moravians, 10, 23, 28-29, 147, 152, 161-63

Morgan, Arthur, 17, 164

Morgan, Griscom, 164-65

Morgan, John, 165

Mormonism, 19

Mourne Grange, 39, 86

Mount, The, 13, 44

Movement Group, 138

Murtle, 12, 32, 44, 131

Myrin, Alarik and Mabel Pew, 140-41

Nazism, 10, 12, 27, 29-30, 164, 166

Nederhoed, Anke. See Weihs, Anke

Neimanis, Inga and Vilnis, 64

Netjek, Petr, 64

New Age, 55

New Left, 15, 47, 177

Newton Dee Village, 12, 32, 38; BA program at, 109-110; coworkers at, 40, 47, 67, 100, 102, 106, 158; employees at, 113, 115, 119-20, 126; festivals at, 150; generational transitions, 54 , $56,58,59,69-78$; parents at, 131 ; villagers at, $42,83,87,92,97$

Nirje, Bengt, 177

Noah, Rudolf, 28

Nonviolent Communication, 79

normalization, 20, 177-78

Northern College, 105

Norway: BA programs in, 109; Camphill places in, $35,38,63,66,70,76-77,98,117,122,124$, 173; Camphill Village Trust, 7, 100, 133-35; deinstitutionalization in, 178 , 197; role in Camphill's expansion, 64; and Wolfson, Julia 192. See also Hogganvik, Solborg, Vidaråsen.

Nottawasaga, 192

Oaklands Park, 170

O'Brien, John, 177

Oliver, Michael, 178
Opitz, Erika, 96

Outward Bound, 39

Owen, Robert, 17, 29, 152-53, 155, 163

Pahkla Camphilli Kula, 64

parents, 81-82, 130-33, 197-98, 201

Peaceful Bamboo Village, 13, 65

Pedersen, Tobias, 59, 100, 185

Pennhurst, 177

Pennine, 49-50

Perceval, 13, 39, 65

personalization, $179-80,184-87,194-95$

Pete's Greens, 76

Pietism, 10, 29, 161-63, 165

Pietzner, Carlo, 12, 13, 32, 46, 155, 163-64

Pietzner, Cornelius, 89, 155

Pietzner, Ursel, 13, 32, 155

Pilgramshain, 12, 28-29, 40

Pioli, Fran, 119-20, 128-29

Pitzer, Don, 16, 18-19, 167

Plant, Andrew, 132, 137, 150

Poole, Richard, 53, 177

Pooler, Russ, 47, 51, 56, 66, 68-69, 117, 119

Prescott College, 107-108

queer theory, 20, 189

Raphael, 2, 18

Ratner, Anne, 131

refugee experience: of Camphill founders,

10, 29-32, 38, 40, 45-46, 82-85, 155, 166,

199-200, 202; of other Camphillers, 98, 102;

of other communal groups, 29, 161-66

Reich, Charles, 177

Reid, David Austin, 86

Reid, Jonathan, 47-48, 50-51, 172, 186-77, 194

retirement policy, 71-72, 79, 116

reverse integration, 5

Reynolds, Vincent, 91-92, 183

Ringwood, 12, 32, 47, 49

Robert Gordon University, 106

Rosenberg, Marshall, 79

Rosicrucians, 147, 163, 206

Roth, Alix, 12, 30-31

Roth, Kate, 50-51

Roth, Peter, 12, 35, 50-51, 53-54, 88, 147, 178, $186-87,199$

Rudolf Steiner College, 109

Rugby, 212n17

Sachs, Ursel. See Pietzner, Ursel

Sadhana Village, 4, 13, 65 
safeguarding, 95, 99, 114, 177, 183, 197

Sander, Marianne, 164

Sands, Stephen, 50, 135, 136, 182-83

Saint Christopher's School, 32, 39

Scharmer, Otto, 193

Schauder, Hans and Lisl, 12, 31, 33

School of Spiritual Science, 109, 138, 155-56

Schwartz, David, 78

Schwartz, Hannah, 74-75, 77-79

Scotland: BA programs in, $58,105,108,109$; boards in, 136; Camphill founding in, 10, 21, 25, 27, 30, 163-64, 175; Camphill Scotland, $46,59,83,104,105,134-35,158-59,182$, 23on19o; and Camphill Village Trust, 133; census in, 112; German coworkers in, 124; incomesharing in, 97-98, social care policy in, 182, 184. See also Blair Drummond, Cairnlee, Camphill School Aberdeen, Garvald, Loch Arthur, Milltown, Murtle, Newton Dee, Simeon, Tiphereth

Seebohm Report, 176-78

self-advocacy, 20, 22, 92-94, 136-37, 189-94, 198, 202, 204

seminar, 12, 32, 36, 40-41, 46, 49, 58, 60, 65-66, $74,103-104,107-108,127-28$

service providers, $83-84,99,185-87$

Shakers, 17

Sheiling Schools, 32, 47

Sheldrake, Rupert, 55

Sigmundsdottir, Sesselja, 28, 174-75

Sikkel, Marjan, 61, 98, 105, 145, 160

Simeon, 63-64, 119

Sleigh, Joan, 155

Smith, Adam, 151

Smith, Patricia, 47

Snow, Judith, 192

social care, 3, 175-95, 202; and BA programs, 106, 109; and boards, 133-37; Camphill in contrast to other models, 22, 88, 154; Camphill's relationship with authorities, 44, 54, 84-85, 91-92, 99, 122; and employees, 100-101, $115-16,118,126$

social model of disability, 14-15, 176, 188-89 social role valorization. See normalization social therapy, 36-37, 88, 98-99, 104, 107-109 social threefolding. See threefold social order Society of the Woman in the Wilderness, 162 Sociological Law, 156-60, 194

Solborg, 70-71, 76-77, 88, 101-102, 113, 148

Sólheimar Ecovillage, 28, 91, 174-75

Soltane, 4, 44-45, 88, 112-13, 135-37, 155, 192

Sonnenhof, 12, 27-29
Sophienhöhe, 27

Spalinger, Hans and Johanna, 64

Speaking for Ourselves, 137, 192

Specht, Otto, 23

spirituality, $1-2,15,22-23,27-28,48-49,55,77$, 79,89

staff kids, 31-32, 58, 77-78, 95, 113, 116-17, 196-98

Stedall, Jonathan, 39

Stein, Walter Johannes, 30

Steiner, Rudolf, 11-12, 210n5; and anthroposophy, $2,5,8-9,18,52,54$; and BA programs and seminar, 104-105, 107, 111; and biodynamics, 9, 170-71; and Christian Community, 9, 95, 146, 149-50; and curative education and social therapy, 10, 22-23, 27-28, 88, 130, 141-43; and etheric Christ, 67; and founders of Camphill, 10, 27-28, 30, 33-34, 75; influence on individual Camphillers, 46-48, 54-55, 67, 120-21, 126, 145, 149-50; and threefold social order, 9, 11, 113, 122, 143-44, 150-60, 172, 206; views on Lucifer and Ahriman, 184-85, 204; and Wolfson, Julia, 193-94

Stella Natura, 78

Stourbridge Houses, 13, 42, 178

Strohschein, Albert, 28

students (at Camphill schools), 81-86, 88-92, 97

Sturm, Martin, 66

Summerhill, 47

Sunfield, 28

SUNY Empire State, 107

Svetlana Village, 64

Taena, 37,164

Taize, 168

Tamera Ecovillage, 157

Templars, 147, 163

Tennessee Valley Authority, 17, 164

Thatcher, Margaret, 179

theosophy, 8, 9, 11, 30, 151-53

Thornbury, 12, 32, 71

"those who came," 35-41

three errors, 37,188

three pillars, $68,145,161,163$

three stars, 29, 152, 163

Threefold Community, 53, 63

threefold social order, 9, 52, 121-23, 141, 143, 150-60, 172, 189-90, 206

Tiphereth, 90, 149

Together for Choice, 202-203

town communities, 42-43, 203

training colleges, 13, 42, 44-45, 63, 65, 92, 124, 137

Triform, 44 
trust money, 73, 98, 120. See also incomesharing, lifesharing coworkers

Tschannen, Ruth, 49-50, 173

Twelve Tribes, 157

Union of the Physically Impaired against Segregation, 188

Unitas Fratrum, 29, 161-62

United States, 85, 97, 100, 103, 140, 203; BA program in, 58, 106, 108; Camphill beginnings in, $13,32,35,38,63$; charitable incorporation in, 133, 135-36; communal movements in, 5, 16-17, 162, 164-65; social care policy in, 177, 179, 201-203; see also Beaver Run, Copake, Ghent, Heartbeet, Hudson, Kimberton Hills, Minnesota, Soltane, Triform

utopias, 2, 3, 16-17, 20, 22-23, 37, 152, 163, 178, 188, 202, 204, 206-207

van Duin, Veronika, 43, 69, 84, 87, 111, 122-23, 125, 206-207

Vanier, Jean, 168

Vidaråsen, 38; Bible Evening at, 147; coworkers at, 46 ; crisis at, 13, 89, 95, 196-98; employees at, 124-25; environmental initiatives at, 173-74; generational transitions at, 53-54, 63; role in founding new Camphill places, 64

Vienna, 10-12, 25-30, 32, 35, 52, 75, 140, 162, 165

village communities, $36-39,86-97$

villagers, 81-97, 111, 136-37

Villeneuve, Crispian, 111

vocational coworkers, 98 . See also

lifesharing coworkers

Vollrath, Jake, 67, 69-70, 87, 92, 100, 110, $125-26,150$

von Freeden, Margarete, 97 von Jeetze family, 29, 40, 86, 171-72

von Stein, Ruairidh, 62, 69, 81, 93-94, 122, 145, 147-48

Vreede, Elisabeth, 12, 30

Waldorf education: as anthroposophical initiative, 9, 104; and BA programs, 107-109; at Camphill places, 32, 36, 64, 98, 114, 131, 141, 187, 199; and curative education, 27; and Festival of Offering, 146; governance of, 54; and Nazism, 30; as source of new coworkers, $47-48,103,120,126$

wastewater treatment, 10, 172-73

Ways to Quality, 159

Wegman, Ita, 11-12, 27-28, 30, 141, 143, 155, 174

Weihs, Anke, 12, 30-31, 33, 53, 85

Weihs, Thomas, 12-13, 35, 46, 86, 97, 111, 176

Wilber, Ken, 55

Wildfeuer, Sherry, 46-47, 50, 78

Wolf, Bernie, 47

Wolfensberger, Wolf, 177, 191

Wolfson, Julia, 192-94, 197-98, 229n169

workshop leaders, 120-21

young coworkers, 57-58, 60, 81-82, 102-12

youth conferences, 52-53, 75-76, 132, 155

youth groups, 12, 27, 29, 32, 35, 52, 75, 140, 213n25

youth guidance communities. See training colleges

Zajonc, Arthur, 145, 193, $223 n 16$

Zen coaching, 77

Zinzendorf, Nicholas von, 29, 33, 152, 161-63

Zipperlen, Helen, 177

Zoar, 162

Zonnehuis, 28 
Founded in 1893 , UNIVERSITY OF CALIFORNIA PRESS publishes bold, progressive books and journals on topics in the arts, humanities, social sciences, and natural sciences - with a focus on social justice issues-that inspire thought and action among readers worldwide.

The UC PRESS FOUNDATION raises funds to uphold the press's vital role as an independent, nonprofit publisher, and receives philanthropic support from a wide range of individuals and institutions - and from committed readers like you. To learn more, visit ucpress.edu/supportus. 
THE CAMPHILL MOVEMENT, one of the world's largest and most enduring networks of intentional communities, deserves both recognition and study. Founded in Scotland at the beginning of the Second World War, Camphill communities still thrive today, encompassing thousands of people living in more than one hundred twenty schools, villages, and urban neighborhoods on four continents. Camphillers of all abilities share daily work, family life, and festive celebrations with one another and their neighbors. Unlike movements that reject mainstream society, Camphill expressly seeks to be "a seed of social renewal" by evolving along with society to promote the full inclusion and empowerment of persons with disabilities, who comprise nearly half of their residents. In this multifaceted exploration of Camphill, Dan McKanan traces the complexities of the movement's history, envisions its possible future, and invites ongoing dialogue between the fields of disability studies and communal studies.

"Dan McKanan knows Camphill better than anyone else in the academic world and has crafted an absorbing account of the movement as it faces challenges eighty years after its founding."

TIMOTHY MILLER, author of The Encyclopedic Guide to American Intentional Communities

"This book serves as a living, working document for the Camphill movement. McKanan shows that disability studies and communal studies have more to offer each other than we recognize."

ELIZABETH SANDERS, Managing Director, Camphill Academy

"With good research and wonderful empathy, McKanan pinpoints not only Camphill's societal significance but also how this eighty-year-old movement can still bring potent remediation for the values and social norms of today's world." RICHARD STEEL, CEO, Karl König Institute

DAN MCKANAN is the Emerson Senior Lecturer at Harvard Divinity School. His research focuses on religion and social transformation, with special emphasis on intentional communities, sustainable agriculture, and leftist activism. His most recent book is Eco-Alchemy: Anthroposophy and the History and Future of Environmentalism.

\section{UNIVERSITY OF CALIFORNIA PRESS www.ucpress.edu}

\footnotetext{
A free open access ebook is available upon publication. Learn more at www.luminosoa.org.

Cover design: Glynnis Koike.

Cover illustration: Weaving by Bill Lewis of Camphill Village Kimberton Hills, Pennsylvania. Design created by Mary Fisher, Isabela Seabra, Saskia Gilfoy, Sue Wiecheld, Johannah Newman, Andrew Abromowitz, Marchen Ohi, Lynn Schatzburg, and Felicity Jeans. Photograph by Ethan Ingsley. Reprinted with permission of the artists.
}

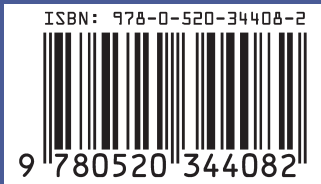

